Cochrane Database of Systematic Reviews

\title{
Exercise-based cardiac rehabilitation for coronary heart disease
} (Review)

Anderson L, Thompson DR, Oldridge N, Zwisler AD, Rees K, Martin N, Taylor RS

Anderson L, Thompson DR, Oldridge N, Zwisler AD, Rees K, Martin N, Taylor RS.

Exercise-based cardiac rehabilitation for coronary heart disease.

Cochrane Database of Systematic Reviews 2016, Issue 1. Art. No.: CD001800.

DOI: 10.1002/14651858.CD001800.pub3.

www.cochranelibrary.com 
TABLE OF CONTENTS

HEADER

ABSTRACT

PLAIN LANGUAGE SUMMARY

SUMMARY OF FINDINGS

BACKGROUND

OBJECTIVES

METHODS

RESULTS

Figure 1.

Figure 2.

Figure 3.

Figure 4.

Figure 5.

Figure 6.

Figure 7.

Figure 8.

Figure 9.

Figure 10.

DISCUSSION

AUTHORS' CONCLUSIONS

ACKNOWLEDGEMENTS

REFERENCES

CHARACTERISTICS OF STUDIES

DATA AND ANALYSES

Analysis 1.1. Comparison 1 Exercise-based rehabilitation versus usual care, Outcome 1 Total mortality.

Analysis 1.2. Comparison 1 Exercise-based rehabilitation versus usual care, Outcome 2 Cardiovascular mortality.

Analysis 1.3. Comparison 1 Exercise-based rehabilitation versus usual care, Outcome 3 Fatal and/or nonfatal MI.

Analysis 1.4. Comparison 1 Exercise-based rehabilitation versus usual care, Outcome 4 CABG.

Analysis 1.5. Comparison 1 Exercise-based rehabilitation versus usual care, Outcome $5 \mathrm{PCl}$.

Analysis 1.6. Comparison 1 Exercise-based rehabilitation versus usual care, Outcome 6 Hospital admissions.

ADDITIONAL TABLES

APPENDICES

WHAT'S NEW

HISTORY

CONTRIBUTIONS OF AUTHORS

DECLARATIONS OF INTEREST

SOURCES OF SUPPORT

DIFFERENCES BETWEEN PROTOCOL AND REVIEW

INDEX TERMS 
[Intervention Review]

\title{
Exercise-based cardiac rehabilitation for coronary heart disease
}

\author{
Lindsey Anderson¹, David R Thompson², Neil Oldridge ${ }^{3}$, Ann-Dorthe Zwisler ${ }^{4}$, Karen Rees ${ }^{5}$, Nicole Martin6, Rod S Taylor ${ }^{1,7}$
}

1Institute of Health Research, University of Exeter Medical School, Exeter, UK. 2Department of Psychiatry, University of Melbourne, Melbourne, Australia. 3University of Wisconsin School of Medicine \& Public Health and Aurora Cardiovascular Services, Aurora Sinai/ Aurora St. Luke's Medical Center, Milwaukee, Wisconsin, USA. ${ }^{4}$ Department of Cardiology, The Heart Centre, Copenhagen University Hospital, Rigshospitalet, Copenhagen, Denmark. ${ }^{5}$ Division of Health Sciences, Warwick Medical School, University of Warwick, Coventry, UK. ${ }^{6}$ Farr Institute of Health Informatics Research, University College London, London, UK. ${ }^{7}$ National Institute of Public Health, University of Southern Denmark, Copenhagen, Denmark

Contact address: Rod S Taylor, Institute of Health Research, University of Exeter Medical School, Veysey Building, Salmon Pool Lane, Exeter, EX2 4SG, UK. r.taylor@exeter.ac.uk.

Editorial group: Cochrane Heart Group

Publication status and date: Edited (no change to conclusions), published in Issue 1, 2018.

Citation: Anderson L, Thompson DR, Oldridge N, Zwisler AD, Rees K, Martin N, Taylor RS. Exercise-based cardiac rehabilitation for coronary heart disease. Cochrane Database of Systematic Reviews 2016, Issue 1. Art. No.: CD001800. DOI: 10.1002/14651858.CD001800.pub3.

Copyright (c 2018 The Cochrane Collaboration. Published by John Wiley \& Sons, Ltd.

\section{A B S T R A C T}

\section{Background}

Coronary heart disease (CHD) is the single most common cause of death globally. However, with falling CHD mortality rates, an increasing number of people live with CHD and may need support to manage their symptoms and prognosis. Exercise-based cardiac rehabilitation (CR) aims to improve the health and outcomes of people with CHD. This is an update of a Cochrane systematic review previously published in 2011.

\section{Objectives}

To assess the effectiveness and cost-effectiveness of exercise-based CR (exercise training alone or in combination with psychosocial or educational interventions) compared with usual care on mortality, morbidity and HRQL in patients with CHD.

To explore the potential study level predictors of the effectiveness of exercise-based CR in patients with CHD.

\section{Search methods}

We updated searches from the previous Cochrane review, by searching Cochrane Central Register of Controlled Trials (CENTRAL) (The Cochrane Library, Issue 6, 2014) from December 2009 to July 2014. We also searched MEDLINE (Ovid), EMBASE (Ovid), CINAHL (EBSCO) and Science Citation Index Expanded (December 2009 to July 2014).

\section{Selection criteria}

We included randomised controlled trials (RCTs) of exercise-based interventions with at least six months' follow-up, compared with a no exercise control. The study population comprised men and women of all ages who have had a myocardial infarction (MI), coronary artery bypass graft (CABG) or percutaneous coronary intervention ( $\mathrm{PCl}$ ), or who have angina pectoris, or coronary artery disease. We included RCTs that reported at least one of the following outcomes: mortality, MI, revascularisations, hospitalisations, health-related quality of life (HRQL), or costs. 


\section{Data collection and analysis}

Two review authors independently screened all identified references for inclusion based on the above inclusion and exclusion criteria. One author extracted data from the included trials and assessed their risk of bias; a second review author checked data. We stratified metaanalysis by the duration of follow up of trials, i.e. short-term: 6 to 12 months, medium-term: 13 to 36 months, and long-term: > 3 years.

\section{Main results}

This review included 63 trials which randomised 14,486 people with CHD. This latest update identified 16 new trials (3872 participants). The population included predominantly post-MI and post-revascularisation patients and the mean age of patients within the trials ranged from 47.5 to 71.0 years. Women accounted for fewer than $15 \%$ of the patients recruited. Overall trial reporting was poor, although there was evidence of an improvement in quality of reporting in more recent trials.

As we found no significant difference in the impact of exercise-based CR on clinical outcomes across follow-up, we focused on reporting findings pooled across all trials at their longest follow-up (median 12 months). Exercise-based CR reduced cardiovascular mortality compared with no exercise control ( 27 trials; risk ratio (RR) $0.74,95 \% \mathrm{Cl} 0.64$ to 0.86 ). There was no reduction in total mortality with CR ( 47 trials, $\mathrm{RR} 0.96,95 \% \mathrm{Cl} 0.88$ to 1.04 ). The overall risk of hospital admissions was reduced with $\mathrm{CR}(15$ trials; $\mathrm{RR} 0.82,95 \% \mathrm{Cl} 0.70$ to 0.96$)$ but there was no significant impact on the risk of MI ( 36 trials; RR $0.90,95 \% \mathrm{Cl} 0.79$ to 1.04 ), CABG ( 29 trials; RR $0.96,95 \% \mathrm{Cl} 0.80$ to 1.16 ) or PCl (18 trials; RR 0.85 , 95\% Cl 0.70 to 1.04 ).

There was little evidence of statistical heterogeneity across trials for all event outcomes, and there was evidence of small study bias for MI and hospitalisation, but no other outcome. Predictors of clinical outcomes were examined across the longest follow-up of studies using univariate meta-regression. Results show that benefits in outcomes were independent of participants' CHD case mix (proportion of patients with MI), type of CR (exercise only vs comprehensive rehabilitation) dose of exercise, length of follow-up, trial publication date, setting (centre vs home-based), study location (continent), sample size or risk of bias.

Given the heterogeneity in outcome measures and reporting methods, meta-analysis was not undertaken for HRQL. In five out of 20 trials reporting HRQL using validated measures, there was evidence of significant improvement in most or all of the sub-scales with exercisebased CR compared to control at follow-up. Four trial-based economic evaluation studies indicated exercise-based CR to be a potentially cost-effective use of resources in terms of gain in quality-adjusted life years.

The quality of the evidence for outcomes reported in the review was rated using the GRADE method. The quality of the evidence varied widely by outcome and ranged from low to moderate.

\section{Authors' conclusions}

This updated Cochrane review supports the conclusions of the previous version of this review that, compared with no exercise control, exercise-based CR reduces the risk of cardiovascular mortality but not total mortality. We saw a significant reduction in the risk of hospitalisation with CR but not in the risk of MI or revascularisation. We identified further evidence supporting improved HRQL with exercise-based CR. More recent trials were more likely to be well reported and include older and female patients. However, the population studied in this review still consists predominantly of lower risk individuals following MI or revascularisation. Further well conducted RCTs are needed to assess the impact of exercise-based CR in higher risk CHD groups and also those presenting with stable angina. These trials should include validated HRQL outcome measures, explicitly report clinical event outcomes including mortality and hospital admissions, and assess costs and cost-effectiveness.

\section{PLAIN LANGUAGE SUMMARY}

\section{Exercise-based rehabilitation for coronary heart disease}

\section{Background}

Coronary heart disease (CHD) is the single most common cause of death globally. However, with falling CHD mortality rates, an increasing number of people live with CHD and may need support to manage their symptoms and reduce the chances of future problems such as heart attacks. Exercise-based cardiac rehabilitation aims to improve the health and outcome of people with CHD.

\section{Study characteristics}

We searched the scientific literature for randomised controlled trials (experiments that randomly allocate participants to one of two or more treatment groups) looking at the effectiveness of exercise-based treatments compared with no exercise in people of all ages with CHD. The search is current to July 2014.

\section{Key results}

This latest update identified 16 trials (3872 participants). We included a total of 63 trials that studied 14,486 people with CHD, predominantly heart attack survivors and those who had undergone heart bypass surgery or angioplasty (a procedure which widens narrowed or obstructed arteries or veins). The findings of this update are consistent with the previous (2011) version of this Cochrane review and show important benefits of exercise-based cardiac rehabilitation that include a reduction in the risk of death due to a cardiovascular 
cause and hospital admission and improvements in health-related quality of life, compared with not undertaking exercise. There was a considerable variation across studies in the reporting of health-related quality of life outcome. A small body of economic evidence was identified indicating exercise-based cardiac rehabilitation to be cost-effective. Further evidence is needed to understand the effect of exercise training in people with CHD who are higher risk and in those with established angina (chest pain).

\section{Quality of evidence}

Although the reporting of methods has improved in recent trials, lack of reporting made it difficult to assess the overall methodological quality and risk of possible bias of the evidence. 


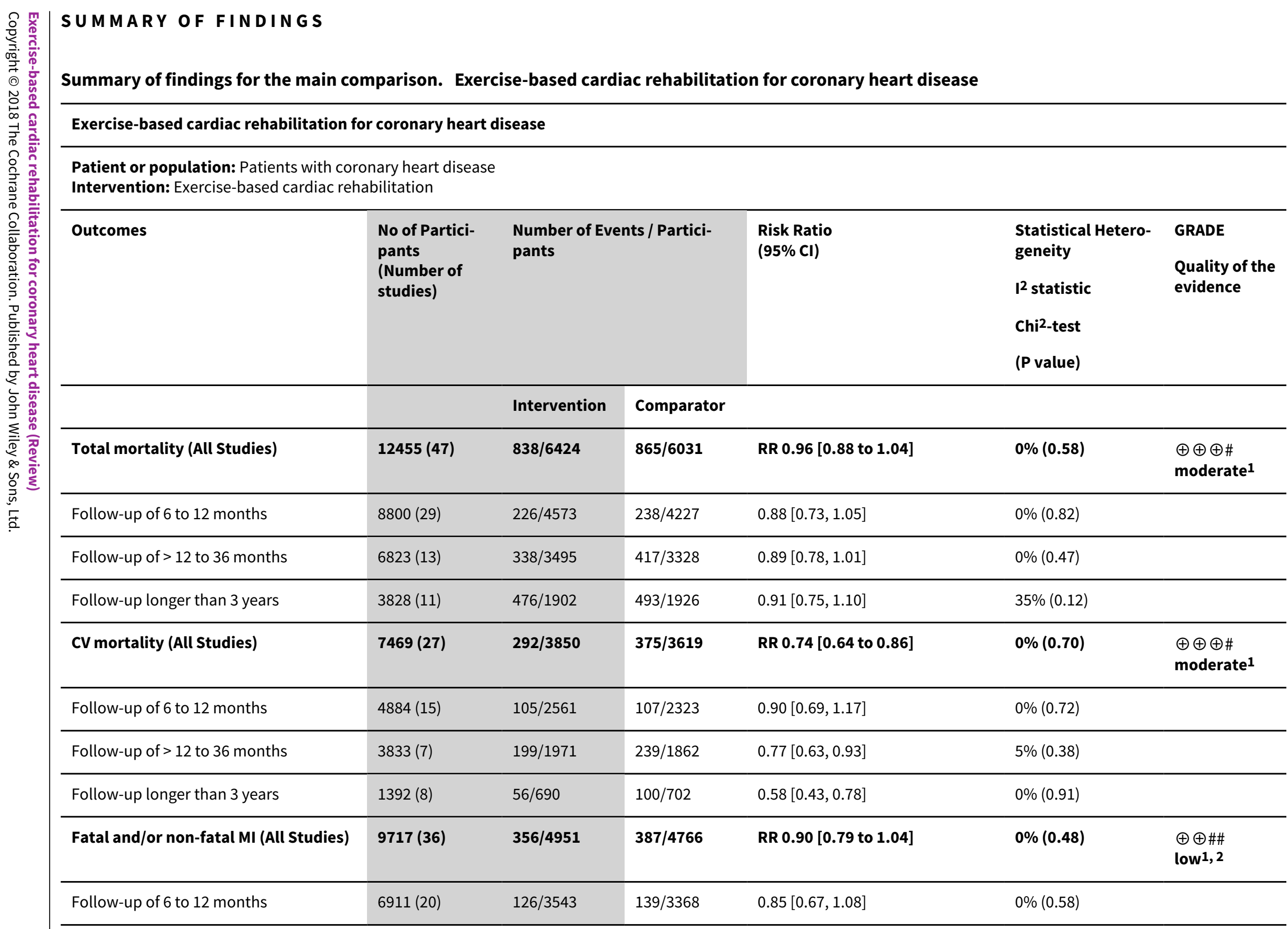




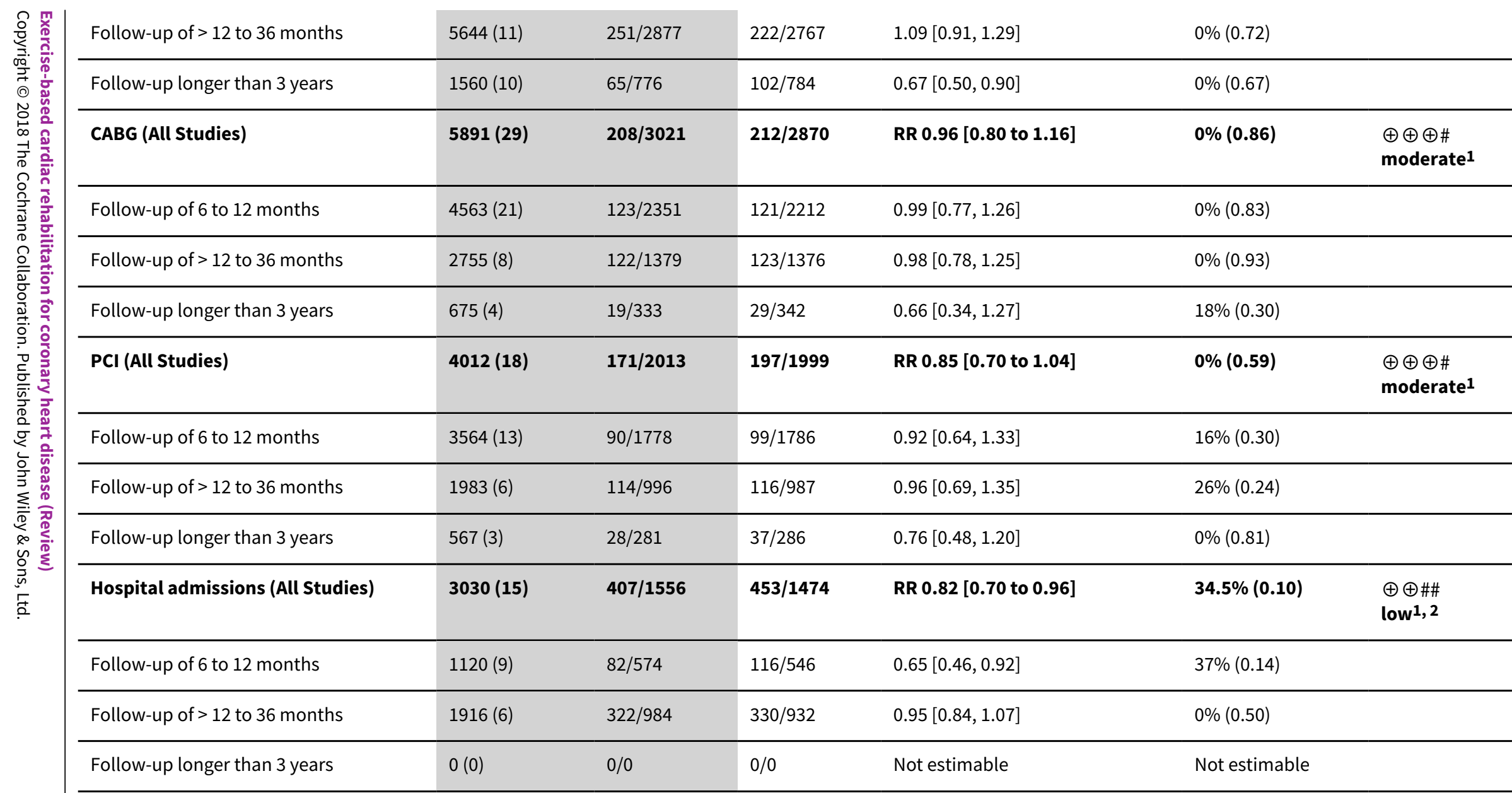

\section{GRADE Working Group grades of evidence}

High quality: Further research is very unlikely to change our confidence in the estimate of effect.

Moderate quality: Further research is likely to have an important impact on our confidence in the estimate of effect and may change the estimate.

Low quality: Further research is very likely to have an important impact on our confidence in the estimate of effect and is likely to change the estimate.

Very low quality: We are very uncertain about the estimate.

1 Random sequence generation, allocation concealment or blinding of outcome assessors were poorly described in over 50\% of included studies; bias likely, therefore quality

of evidence downgraded by one level.

2 Funnel Plots and / or Egger test suggest evidence of asymmetry, therefore quality of evidence downgraded by one level. 


\section{B A C K G R O U N D}

\section{Description of the condition}

Coronary heart disease (CHD) is the single most common cause of death globally, with 7.4 million deaths in 2013, accounting for one-third of all deaths (WHO 2014). In the United Kingdom (UK), an estimated 2.3 million people live with CHD and the condition accounts for one in five deaths in men and one in ten deaths in women (Nichols 2012; Townsend 2012). Although the mortality rate from CHD has been falling in the UK, primarily due to evidencebased treatments and reductions in major risk factors, principally smoking (Unal 2004), it has fallen more slowly in those aged less than 55 years, and less than in many other developed countries (Nichols 2012; Townsend 2012). With falling CHD mortality rates, an increasing number of people live with $\mathrm{CHD}$ and may need support to manage their symptoms and prognosis.

\section{Description of the intervention}

Many definitions of cardiac rehabilitation (CR) have been proposed. The following definition encompasses the key concepts of CR: "The coordinated sum of activities required to influence favourably the underlying cause of cardiovascular disease, as well as to provide the best possible physical, mental and social conditions, so that the patients may, by their own efforts, preserve or resume optimal functioning in their community and through improved health behaviour, slow or reverse progression of disease" (BACPR 2012). Cardiac rehabilitation is a complex intervention that may involve a variety of therapies, including exercise, risk factor education, behaviour change, psychological support, and strategies that are aimed at targeting traditional risk factors for cardiovascular disease. Cardiac rehabilitation is an essential part of contemporary heart disease care and is considered a priority in countries with a high prevalence of $\mathrm{CHD}$. Indeed, based on evidence from previous meta-analyses (Clark 2005; Piepoli 2004; Taylor 2004), CR following a cardiac event is a Class I recommendation from the European Society of Cardiology, the American Heart Association and American College of Cardiology, with exercise therapy consistently identified as a central element (Balady 2011; Perk 2012; Smith 2011). However, despite the recommendations for exercise-based $\mathrm{CR}$ as an integral component of comprehensive cardiac care of patients with CHD (particularly those following myocardial infarction (MI), revascularisation or with angina pectoris) and heart failure, a substantial proportion of patients do not receive it (Bethell 2008). Service provision, though predominantly hospital-based, varies markedly, and referral, enrolment and completion are suboptimal, especially among women and older people (Beswick 2004, Clark 2012). Home-based CR programmes have been increasingly introduced to widen access and participation (Taylor 2010), and interventions aimed at improving patient uptake and adherence to CR programmes have been adopted (Karmali 2014).

Exercise-based CR is remarkably safe. An observational study of more than 25,000 patients undergoing CR reported one cardiac event for 50,000 hours of exercise training, equivalent to 1.3 cardiac arrests per million patient-hours (Pavy 2006). An earlier study reported one case of ventricular fibrillation per 111,996 patienthours of exercise and one MI per 294,118 patient-hours (Van Camp 1986). Patients with unstable angina, uncontrolled ventricular arrhythmia, and severe heart failure (New York Heart Association level 4) have been considered at high risk, with careful assessment recommended before they engage in the exercise component of CR. (BACPR 2012).

\section{How the intervention might work}

Exercise training has been shown to have direct benefits on the heart and coronary vasculature, including myocardial oxygen demand, endothelial function, autonomic tone, coagulation and clotting factors, inflammatory markers, and the development of coronary collateral vessels (Clausen 1976; Hambrecht 2000). However, findings of the original Cochrane review of exercisebased CR for CHD (Jolliffe 2001) supported the hypothesis that reductions in mortality may also be mediated via the indirect effects of exercise through improvements in the risk factors for atherosclerotic disease (i.e. lipids, smoking and blood pressure) (Taylor 2006).

\section{Why it is important to do this review}

This is an update of a Cochrane review published in 2011 which identified 47 randomised controlled trials (RCTs) randomising a total of 10,794 patients (Heran 2011). A reduction in overall and cardiovascular mortality (risk ratio (RR): $0.87,95 \% \mathrm{Cl} 0.75$ to 0.99 and RR $0.74,95 \% \mathrm{Cl} 0.63$ to 0.87 ) and hospital admissions (RR $0.69,95 \% \mathrm{Cl} 0.51$ to 0.93 ) in the shorter term (trials with follow up $\leq 12$ months follow-up) was reported with no evidence of heterogeneity of effect across trials. Exercise-based CR was not found to reduce the risk of morbidity in terms of the risk of recurrent myocardial infarction or risk of revascularisation. Given both the heterogeneity in outcome measure and methods of reporting findings, a meta-analysis was not undertaken for health-related quality of life (HRQL) outcomes, although there was evidence of a higher level of HRQL with exercise-based CR than usual care in the seven (out of 10 ) trials reporting validated HRQL outcome measures.

The 2011 review identified a number of limitations in the available RCT evidence, the most notable of which are listed below.

- Under-representation of women, elderly people, and other cardiac groups (post revascularisation and angina pectoris).

- Poor reporting of methodology and results in many trial publications. The method of randomisation, allocation, concealment, or blinding of outcomes assessment was rarely described. Furthermore, incomplete outcome data (primarily due to losses to follow-up or dropouts) were insufficiently addressed in most trials. Losses to follow-up were relatively high across trials (approximately one third of trials reported a greater than $20 \%$ loss to follow-up) but reasons for dropout were often not reported.

- Several trials excluded significant numbers of patients postrandomisation, and thus in an intention-to-treat analysis, these patients were regarded as dropouts. This may be partly explained by the fact that the majority of trials were not designed (or powered) to assess treatment group differences in mortality and morbidity but instead surrogate measures of treatment efficacy, such as exercise capacity or cardiac risk factor levels.

- Lack of robust evidence for the impact on HRQL, costs and costeffectiveness.

The 2011 review authors concluded that well designed and adequately reported RCTs in groups of CHD patients more 
representative of usual clinical practice are needed. It was also recommended that these trials should include validated HRQL outcome measures, explicitly report clinical events including hospital admission, and assess costs and cost-effectiveness.

Using additional RCT evidence published since the 2011 Cochrane review, the aim of this update was to reassess the effectiveness of exercise-based CR compared to usual care on mortality, risk of hospital admissions, myocardial infarction, revascularisation, HRQL, and costs and cost-effectiveness in patients with CHD.

\section{Changes in this update review}

In addition to updating the searches, given the increased number of RCTs reporting longer follow up, this update review has stratified the results of meta-analyses according to time of follow-up: shortterm, 6-12 months; medium-term,13-36 months; and long-term, > 36 months (follow-up is likely to be a key driver of intervention effect), and has assessed the quality of the evidence for reported outcomes using the GRADE framework (Schünemann 2011).

\section{O B JE C T IVES}

- To assess the effectiveness and cost-effectiveness of exercisebased CR (exercise training alone or in combination with psychosocial or educational interventions) compared with usual care on mortality, morbidity and HRQL in patients with CHD.

- To explore the potential study level predictors of the effectiveness of exercise-based CR in patients with CHD.

\section{METHODS}

\section{Criteria for considering studies for this review Types of studies}

We sought RCTs of exercise-based CR versus usual care with a follow-up period of at least six months.

\section{Types of participants}

We included men and women of all ages, in both hospital-based and community-based settings, who have had a Ml, or who had undergone revascularisation (coronary artery bypass grafting (CABG), percutaneous coronary intervention $(\mathrm{PCI})$ ) or who have angina pectoris or coronary artery disease defined by angiography.

We excluded studies which only included participants following heart valve surgery, with heart failure, with atrial fibrillation, with heart transplants, or implanted with either cardiacresynchronisation therapy (CRT) or implantable defibrillators (ICD). These indications are the subject of other Cochrane reviews (Risom 2014; Sibilitz 2014; Taylor 2014). We also excluded studies of participants who had completed a CR programme prior to randomisation.

\section{Types of interventions}

Exercise-based CR is defined as a supervised or unsupervised inpatient, outpatient, community- or home-based intervention which includes some form of exercise training that is applied to a cardiac patient population. The intervention could be exercise training alone or exercise training in addition to psychosocial or educational interventions, or both (i.e. "comprehensive CR").
Usual care could include standard medical care, such as drug therapy, but without any form of structured exercise training or advice.

\section{Types of outcome measures}

We included studies which reported one or more of the following outcomes:

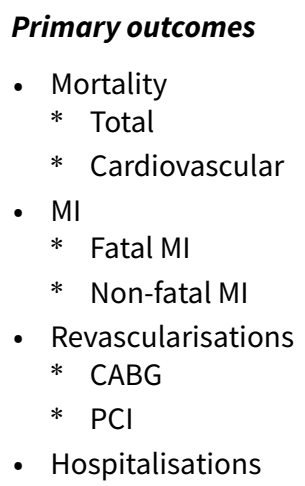

\section{Secondary outcomes}

- Health-related quality of life assessed using validated instruments (e.g. SF-36, EQ-5D)

- Costs and cost-effectiveness

\section{Search methods for identification of studies}

The search from the previously published Cochrane review (Heran 2011) was updated by searching the Cochrane Central Register of Controlled Trials (CENTRAL) in The Cochrane Library (Issue 6, 2014), Database of Abstracts of Reviews of Effects (DARE) (Issue 2, 2014), Health Technology Assessment (HTA) (Issue 2, 2014), MEDLINE \& Medline in Process (OVID) (1946 to 2nd July 2014), EMBASE (OVID) (1980 to week 26, 2014) and CINAHL Plus (EBSCO) (1937 to 3 July 2014). Conference proceedings were searched on Science on Web of Science Core Collection (Thomson Reuters) (1970 to June 2014). We hand-searched reference lists of retrieved articles and systematic reviews published since the last update, for any studies not identified by the electronic searches. We searched trial registers (WHO's ICTRP and Clinicaltrials.gov) for on-going clinical trials and also sought expert advice.

We designed search strategies with reference to those of the previous systematic review (Heran 2011). We added new search terms to expand the search to include percutaneous coronary intervention $(\mathrm{PCl})$ and related interventions, and also anginarelated conditions such as acute coronary syndrome (ACS). We also added terms relating to education and psychological interventions to better reflect the comprehensive nature of $C R$. We searched MEDLINE, EMBASE and CINAHL using a strategy combining selected $\mathrm{MeSH}$ terms and free text terms relating to exercise-based rehabilitation and coronary heart disease with filters applied to limit to humans and RCTs.The RCT filter for MEDLINE was the Cochrane sensitivity-maximising RCT filter, and for EMBASE, terms recommended in the Cochrane Handbook were applied (Lefebvre 2011). Adaptations of this filter were applied to CINAHL and Web of Science. We translated the MEDLINE search strategy into the other databases using the appropriate controlled vocabulary as applicable. We applied date limits to the previously used search terms, and limited searches in The Cochrane Library by publication 
years 2009-2014. We applied the new terms without time limits. We imposed no language or other limitations and gave consideration to variations in terms used and spellings of terms in different countries so that studies were not missed by the search strategy because of such variations. See Appendix 1 for details of the search strategies used.

\section{Data collection and analysis}

\section{Selection of studies}

Two reviewers (LA and RST) independently examined the titles and abstracts of citations identified by the electronic searches for possible inclusion and coded them as 'retrieve' (eligible or potentially eligible/unclear) or 'do not retrieve'. We retrieved full text publications of potentially relevant studies (and had them translated into English where required) and two reviewers (LA and RST) then independently determined study eligibility using a standardised inclusion form. We resolved any disagreements about study eligibility by discussion and, if necessary, a third reviewer (ADZ) was asked to arbitrate.

\section{Data extraction and management}

One reviewer (LA) extracted study characteristics of included RCTs and outcome data using a standardised data collection form which had been piloted on two RCTs included in the review. A second author (RST) checked all extracted data for accuracy. We resolved disagreements by consensus. If data were presented numerically (in tables or text) and graphically (in figures), the numeric data were used because of possible measurement error when estimating from graphs. A second reviewer (RST) confirmed all numeric calculations and extractions from graphs or figures. Any discrepancies were resolved by consensus. One author (LA) transferred extracted data into Review Manager 5.3 (RevMan 2014), and a second author (RST) spot-checked data for accuracy against the systematic reviews.

Data on patient characteristics (e.g. age, sex, CHD diagnosis) and details of the intervention (including mode of exercise, duration, frequency and intensity), description of usual care and length of follow-up were also extracted.

If there were multiple reports of the same study, we assessed the duplicate publications for additional data. We extracted outcome results at all follow-up points post-randomisation. We contacted study authors where necessary to provide additional information.

\section{Assessment of risk of bias in included studies}

One reviewer (LA) assessed the risk of bias in included studies using the Cochrane Collaboration's recommended tool, which is a domain-based critical evaluation of the following core risk of bias items: the quality of random sequence generation and allocation concealment, description of drop-outs and withdrawals, blinding of outcome assessment, and presence of selective reporting (Higgins 2011). We also assessed three further quality criteria: whether the study groups were balanced at baseline, if the study groups received comparable care (apart from the exercise component of the intervention), and whether an intention-to-treat analysis was undertaken. The criteria used for assessing these last three risk of bias domains are as follows.

\section{Groups balanced at baseline}

- Low risk of bias: the characteristics of the participants in the intervention and control groups at baseline is reported to be comparable or can be judged to be comparable (e.g. baseline data reported in Table 1 ) in terms of likely main prognostic factors.

- Uncertain risk of bias: it is not reported whether the participants' characteristics in the two groups are balanced at baseline and there is inadequate information reported (e.g. no Table 1) to assess this.

- High risk of bias: there is evidence of substantive imbalance in the baseline characteristics of the intervention and control groups with regard to likely major prognostic factors.

\section{Intention-to-treat analysis}

- Low risk of bias: the trial reports that the analyses were conducted according to an intention-to-treat analysis, and includes all the principles of such an analysis, e.g. keeping participants in the intervention groups to which they were randomised, regardless of the intervention they actually received; and measures outcome data on all or the majority of participants (i.e. $>80 \%$ of those randomised) or includes imputation of all missing data in the analysis, using appropriate methodology, e.g. multiple imputation.

- Uncertain risk of bias: it is unclear if the trial has performed an intention-to-treat analysis.

- High risk of bias: the trial does not include an intention-to-treat analysis, or there is a substantive loss of outcome data (e.g. $>20 \%$ ) and analyses are performed according to imputation methods known to create bias such as last observation carried forward.

\section{Groups received comparable treatment (except exercise)}

- Low risk of bias: all co-interventions were delivered equally across intervention and control groups.

- Uncertain risk of bias: there was insufficient information to access whether co-interventions were equally delivered across groups.

- High risk of bias: the co-interventions were not delivered equally across intervention and control groups.

All risk of bias assessments were checked by a second reviewer (RST) and any discrepancies were resolved by consensus. Details of the assessments of risk of bias for each included trial are shown in the Characteristics of included studies table.

\section{Quality of evidence in included reviews}

One author (LA) used GRADEProfiler software to assess the quality of evidence for outcomes reported in the review (GRADEpro GDT 2015), based on the following factors: indirectness of evidence, unexplained heterogeneity, publication bias, risk of bias due to study design limitations and imprecision of results (Balshem 2011). A second author (RST) checked the assessment.

\section{Data analysis}

We processed data in accordance with the Cochrane Handbook for Systematic Reviews of Interventions (Deeks 2011). Dichotomous outcomes for each comparison have been expressed as risk ratios (RR) with 95\% confidence intervals (Cl). If there was a statistically significant absolute risk difference, the associated number needed 
to treat for an additional beneficial or harmful outcome was calculated. Heterogeneity amongst included studies was explored qualitatively, by comparing the characteristics of included studies, and quantitatively, using the $\mathrm{Chi}^{2}$ test of heterogeneity and $\mathrm{I}^{2}$ statistic (Higgins 2003). Given the clinical heterogeneity of the included trials, we pooled data from each study using a random effects model. Compared with a fixed-effects, this model provides a more conservative statistical comparison of the difference between intervention and control by typically providing a wider confidence interval around the effect estimate. If a statistically significant difference was present using the random-effects model, we also reported the fixed effect pooled estimate and $95 \% \mathrm{Cl}$ because of the tendency of smaller trials, which are more susceptible to publication bias, to be over weighted with a random effects analysis (Heran 2008a; Heran 2008b). We planned to pool the results for HRQL using a standardised mean difference (SMD) but this was not possible due to the heterogeneity in outcome measures and methods of reporting findings.

As length of follow-up was anticipated to be a driver of intervention effect, we stratified meta-analysis of each outcome according to the length of trial duration i.e. 'short-term' follow up ( 6 to 12 months); 'medium-term' follow-up (13 to 36 months), and 'long-term' follow-up ( > 36 months). Univariate meta-regression was undertaken to explore heterogeneity and examine potential treatment effect modifiers. We tested nine hypotheses that there may be differences in the effect of exercise-based CR on total mortality, cardiovascular mortality, total $\mathrm{MI}$, revascularisation (CABG and $\mathrm{PCI}$ ) and hospitalisation across particular subgroups: (1) CHD case mix (MI-only trials versus other trials); (2) type of CR (exercise-only CR versus comprehensive CR); (3) 'dose' of exercise intervention [dose $=$ number of weeks of exercise training $x$ average number of sessions/week $x$ average duration of session in minutes] (dose $\geq 1000$ units versus dose $<1000$ units); (4) follow-up period; (5) year of publication; (6) sample size; (7) setting (home- or centrebased CR); (8) risk of bias (low risk of bias in $<5$ out of 8 domains) ; and (9) study location (continent). Hypotheses (1) to (5) were defined a priori and (7) to (9) during this update. Given the relatively small ratio of trials to covariates, meta-regression was limited to univariate analysis (Deeks 2011). The permute option in STATA was used to allow for multiple testing in meta-regression (StataCorp 2013).

We used the funnel plot and the Egger test to examine small study bias (Egger 1997). We processed data in accordance with the Cochrane Handbook for Systematic Reviews of Interventions (Deeks 2011). We completed data synthesis and analyses using Review Manager 5.3 software (RevMan 2014) and STATA version 13.0 (StataCorp 2013).

\section{RES U L T S}

\section{Description of studies}

The previous version of this review (Heran 2011) included 30 trials (55 publications) from the original Cochrane review (Andersen 1981; Bell 1998; Bengtsson 1983; Bertie 1992; Bethell 1990; Carlsson 1998; Carson 1982; DeBusk 1994; Engblom 1996; Erdman 1986; Fletcher 1994; Fridlund 1991; Haskell 1994; Heller 1993; Holmbäck 1994; Kallio 1979; Leizorovicz 1991; Lewin 1992; Miller 1984; Oldridge 1991; Ornish 1990; Schuler 1992; Shaw 1981; Sivarajan 1982; Specchia 1996; Stern 1983; Vecchio 1981; Vermeulen 1983; WHO 1983; Wilhelmsen 1975) and an additional 17 studies (26 publications) identified by the updated search (Belardinelli 2001; Bäck 2008; Dugmore 1999; Giallauria 2008; Hofman-Bang 1999; Kovoor 2006; La Rovere 2002; Manchanda 2000; Marchionni 2003; Seki 2003; Seki 2008; Ståhle 1999; Toobert 2000; VHSG 2003; Yu 2003; Yu 2004; Zwisler 2008). This 2015 update identified an additional 16 trials (20 publications) (Aronov 2010; Bettencourt 2005; Briffa 2005; Hambrecht 2004; Higgins 2001; Houle 2012; Maddison 2014; Maroto 2005; Munk 2009; Mutwalli 2012; Oerkild 2012; Reid 2012; Roman 1983; Sandström 2005; Wang 2012; West 2012) as well as one publication (Dorn 1999) which provided further follow-up data of a study included in the original review (Shaw 1981). The study selection process is summarised in the PRISMA flow diagram shown in Figure 1 (Liberati 2009). A total of 63 studies reporting data for a total of 14,486 patients have been included in this review update. 
Figure 1. Summary of study selection process

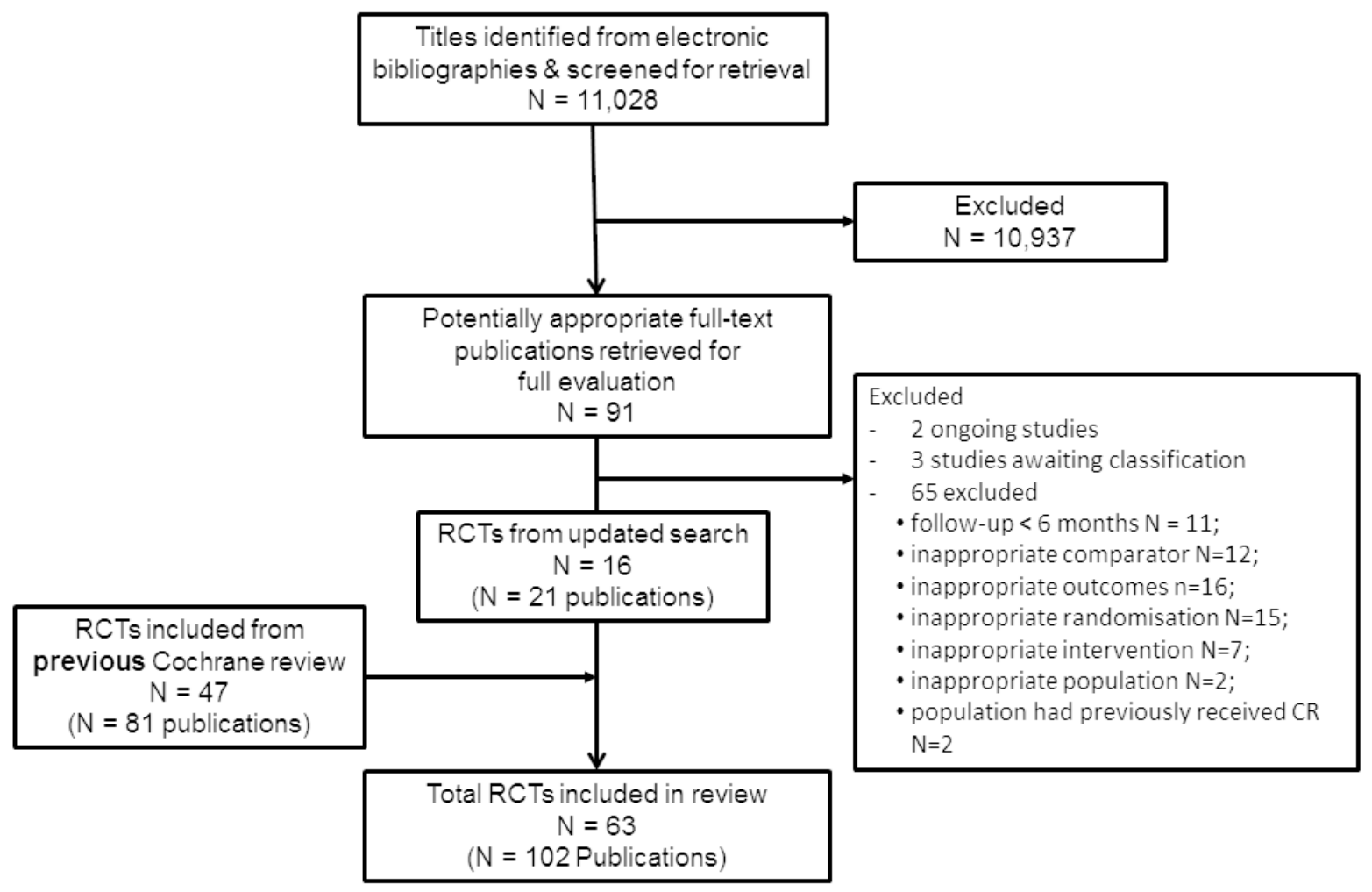

Details of the studies included in the review are listed in the Characteristics of included studies table. Thirty eight studies compared comprehensive programmes (i.e. exercise plus education or psychological management, or both), while 24 reported on an exercise-only intervention. In addition, one study randomised patients to a comprehensive programme, exercise only intervention or usual care (Sivarajan 1982). The majority of studies (37 studies, 59\%) were undertaken in Europe, either as single ( $\mathrm{n}=$ $45)$ or multicentre $(n=18)$ studies. Most trials were relatively small in sample size (median 126, range: 28-2304). Two large trials (WHO 1983; West 2012) contributed about 30\% (4997 participants) of all included participants. The median duration of trial intervention was six months (range 1 to 48) with median follow-up of 12 months (range 6 to 120) months. Patients with $\mathrm{Ml}$ alone were recruited in 31 trials (49\%); the remaining trials recruited patients suffering exclusively from angina (five trials), post-revascularisation patients (two trials) or a mixed population of patients with CHD. The mean age of patients within the trials ranged from 49.3 to 71.0 years. Although over half of the trials included women (42 studies, $67 \%$ ), women accounted for less than $15 \%$ of the patients recruited overall. More recent trials were less dominated by MI patients and were more likely to include older and female participants. The average mean age of patients within trials rose from 56.3 years for trials published prior to 2005 , to 61.7 years for trials published since 2005. In this time, the proportion of women in trials increased from $12.7 \%$ to $20.7 \%$.
The CR programmes were commonly delivered in either an exclusively supervised centre-based setting or a centre-based setting in combination with some home exercise sessions. Fifteen studies were conducted in an exclusively home-based setting (Bäck 2008; Bell 1998; DeBusk 1994; Fletcher 1994; Haskell 1994; Heller 1993; Higgins 2001; Houle 2012; Lewin 1992; Maddison 2014; Miller 1984; Mutwalli 2012; Oerkild 2012; Reid 2012; Wang 2012), with two of these studies randomising patients to usual care, or to an electronically-delivered intervention designed to increase exercise behaviour, accessed via a mobile phone or the internet (Maddison 2014; Reid 2012).The mode of exercise training in CR programmes was aerobic in nature and most commonly static cycling, walking or circuit training.The dose of exercise ranged considerably across trials, in overall duration (range 1 to 48 months), frequency (1 to 7 sessions/week), session length (20 to 90 minutes/session) and intensity ( $50 \%$ to $85 \%$ of maximal heart rate; $50 \%$ to $95 \%$ of maximal oxygen uptake $\left(\mathrm{VO}_{2} \mathrm{max}\right)$; Borg rating of 11 to 15$)$. Due to poor and inconsistent reporting of adherence and fidelity to exercise programmes in the RCTs, we were not able to consider the actual amount of exercise that the participants received or performed in this review. In general, comparator groups were described as receiving usual or standard care, which might have included medication, education and advice about diet and exercise, or psychosocial support, or both, but no formal exercise training. One trial (Hambrecht 2004) compared exercise training to stent angioplasty for patients with stable angina, while another (Kovoor 2006) compared exercise training to an "early return to normal 
activities group" where patients returned to work two weeks following a MI, without a formal CR programme.

Sixty eight publications identified in the current search were excluded for reasons listed in the Characteristics of excluded studies table. The most common reasons for exclusion were a failure to report any of the pre-specified outcomes of this review update, or that the study was not a RCT. The status of ongoing trials which meet the inclusion criteria of this review are detailed in the Characteristics of ongoing studies table.

\section{Risk of bias in included studies}

The overall risk of bias was low or unclear. A number of trials failed to give sufficient detail to assess their potential risk of bias although the quality of reporting was generally higher in more recently published trials (Figure 2).

\section{Figure 2. Risk of bias graph: review authors' judgements about each risk of bias item presented as percentages across all included studies.}

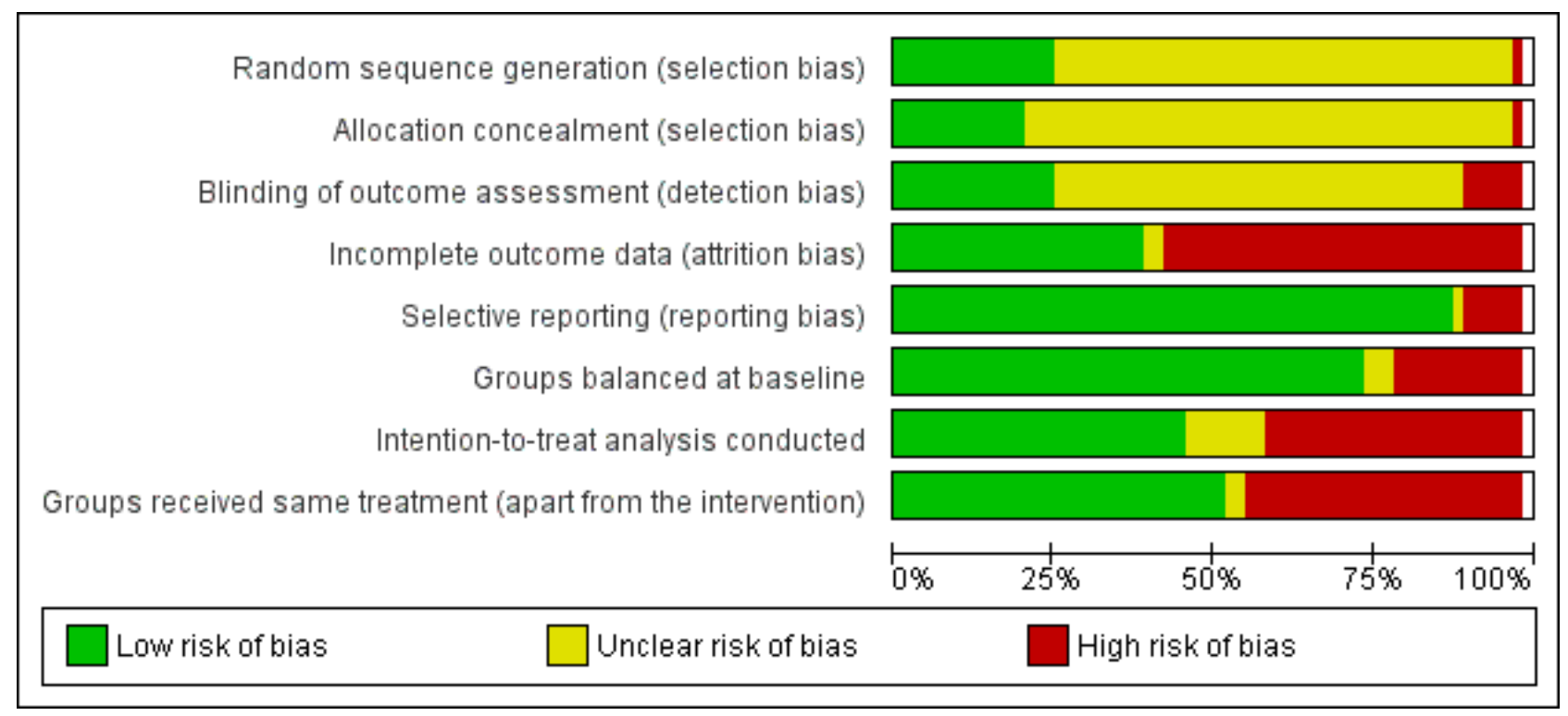

\section{Allocation}

Nearly all the trial publications reported that the trial was 'randomised' but did not provide sufficient details to assess whether the method was appropriate. A total of $16 / 63(25 \%)$ studies reported details of appropriate generation of the random sequence (Andersen 1981; Bell 1998; Bethell 1990; Briffa 2005; Erdman 1986; Hambrecht 2004; Haskell 1994; Holmbäck 1994; Houle 2012; Maddison 2014; Munk 2009; Oerkild 2012; Reid 2012; Wang 2012; Wilhelmsen 1975; Zwisler 2008) and 13/63 (21\%) studies reported appropriate concealment of allocation (Bell 1998; Briffa 2005; Haskell 1994; Holmbäck 1994; Kovoor 2006; Maddison 2014; Munk 2009; Oerkild 2012; Reid 2012; Schuler 1992; VHSG 2003; West 2012; Zwisler 2008).

\section{Blinding}

Given the nature of the exercise-based CR intervention, it is not possible to blind participants or programme personnel. Only 16/63 studies $(25 \%)$ reported adequate details of blinding of outcome assessment (Fletcher 1994; Giallauria 2008; Hambrecht 2004; Holmbäck 1994; Lewin 1992; Maddison 2014; Manchanda 2000; Marchionni 2003; Munk 2009; Ornish 1990; Reid 2012; Sandström 2005; Schuler 1992; West 2012; Wilhelmsen 1975; Zwisler 2008).

\section{Incomplete outcome data}

Although losses to follow-up and drop-out were relatively high (ranging from $21 \%$ to $48 \%$ in trials where losses to follow up were reported), follow-up of $80 \%$ or more was achieved in $45 / 63(71 \%)$ studies (Andersen 1981; Aronov 2010; Belardinelli 2001; Bell 1998; Bethell 1990; Bettencourt 2005; Bäck 2008; Briffa 2005; Carlsson 1998; Dugmore 1999; Engblom 1996; Giallauria 2008; Hambrecht 2004; Haskell 1994; Heller 1993; Holmbäck 1994; Kallio 1979; La Rovere 2002; Leizorovicz 1991; Lewin 1992; Maddison 2014; Manchanda 2000; Marchionni 2003; Maroto 2005; Miller 1984; Munk 2009; Oerkild 2012; Oldridge 1991; Roman 1983; Sandström 2005; Schuler 1992; Seki 2003; Shaw 1981; Specchia 1996; Stern 1983; Ståhle 1999; Toobert 2000; Vermeulen 1983; VHSG 2003; Wang 2012; West 2012; Wilhelmsen 1975; Yu 2003; Zwisler 2008). However, reasons for loss to follow-up and dropout were often not reported, and only $25 / 63(40 \%)$ of studies were judged to have adequately reported reasons for loss to follow-up, thus having a low risk of bias, with $36 / 63$ (57\%) studies judged as having a high risk of bias and two studies having an unclear risk of bias.

\section{Selective reporting}

While the majority $(56 / 63 ; 89 \%)$ of trials reported all outcomes listed in the methods section, six trials failed to report all outcomes at all time points collected (La Rovere 2002; Manchanda 2000; Oerkild 2012; Ornish 1990; Specchia 1996; Toobert 2000) and one trial was judged as having an unclear risk of bias as it didn't clearly describe the outcomes to be collected in the methods section (Wilhelmsen 1975). A number of the included studies were not designed to assess treatment group differences in morbidity and mortality (as these were not the primary outcomes of these trials) and, therefore, may not have fully reported all clinical events 
that occurred during the follow-up period. All studies collecting validated $\mathrm{HRQL}$ outcomes fully reported these outcomes.

\section{Other potential sources of bias}

\section{Groups balanced at baseline}

The majority of studies $(47 / 63 ; 75 \%)$ reported the baseline characteristics of participants in the intervention and comparator groups to be comparable in terms of likely main prognostic factors, or provided sufficient data for them to be judged to be comparable. In 13 studies there was evidence of substantive imbalance in the baseline characteristics of the intervention and control groups with regard to likely major prognostic factors (Bäck 2008; Carson 1982; Fletcher 1994; Haskell 1994; Hofman-Bang 1999; Kovoor 2006; Lewin 1992; Manchanda 2000; Specchia 1996; Stern 1983; Toobert 2000; WHO 1983; Wilhelmsen 1975), while three further studies reported inadequate information to assess whether the two groups were balanced (Bell 1998; Carlsson 1998; Vermeulen 1983).

\section{Intention-to-treat analysis conducted}

Twenty nine of the studies (46\%) reported that their analysis was conducted according to an intention-to-treat analysis, and measured outcome data on all or the majority of participants, or included imputation of all missing data using appropriate methodology in the analysis (Andersen 1981; Bäck 2008; Belardinelli 2001; Bengtsson 1983; Bettencourt 2005; Briffa 2005; Carlsson 1998; DeBusk 1994; Engblom 1996; Fletcher 1994; Fridlund 1991; Hambrecht 2004; Heller 1993; Houle 2012; Maddison 2014; Kovoor 2006; La Rovere 2002; Leizorovicz 1991; Oerkild 2012; Reid 2012; Roman 1983; Sandström 2005; Shaw 1981; Specchia 1996; Vecchio 1981; Vermeulen 1983; Wang 2012; West 2012; Zwisler 2008). Eight studies provided insufficient detail to determine if the trial performed an intention-to-treat analysis (Aronov 2010; Bell 1998; Dugmore 1999; Manchanda 2000; Munk 2009; Seki 2008; Toobert 2000; WHO 1983), while the remaining 26 studies did not conduct an intention-to-treat analysis, or use appropriate methodology for imputation of missing data.

\section{Groups received comparable treatment}

Thirty three studies (52\%) were judged to have a low risk of bias, with all co-interventions being described as being delivered equally to both the intervention and comparator groups (Andersen 1981; Aronov 2010; Bäck 2008; Belardinelli 2001; Bertie 1992; Bethell 1990; Bettencourt 2005; Briffa 2005; Carson 1982; Dugmore 1999; Engblom 1996; Erdman 1986; Fletcher 1994; Giallauria 2008; Hambrecht 2004; Holmbäck 1994; Houle 2012; La Rovere 2002; Maddison 2014; Marchionni 2003; Miller 1984; Munk 2009; Mutwalli 2012; Oerkild 2012; Sandström 2005; Schuler 1992; Shaw 1981; Specchia 1996; Ståhle 1999; Stern 1983; Vecchio 1981; Wang 2012; Wilhelmsen 1975). Twenty eight studies (44\%) were judged to have a high risk of bias as the intervention included additional components that were not received by the comparator group. Two studies did not describe the intervention and comparator groups with sufficient detail to assess if the two groups received comparable treatment (Bell 1998; Roman 1983).

\section{Effects of interventions}

See: Summary of findings for the main comparison Exercisebased cardiac rehabilitation for coronary heart disease

\section{Clinical Events}

\section{Mortality}

Forty seven ( $N=12,455$ participants) of the included studies reported total mortality (Analysis 1.1, Figure 3). Four trials contributed mortality data at more than one follow-up period (WHO 1983; Wilhelmsen 1975; Shaw 1981; West 2012). Compared with control, while there was a reduction in total mortality with exercise-based CR in trials with short- ( 29 trials, RR: $0.88,0.73$ to 1.05 ) and medium-term follow-up ( 13 trials, RR $0.89,95 \% \mathrm{Cl} 0.78$ to 1.01 ) this failed to reach statistical significance. There was no evidence of a difference between groups in the long-term follow-up (11 trials, RR $0.91,95 \% \mathrm{Cl} 0.75$ to 1.10 ) or across all trials reporting this outcome ( 47 trials, RR $0.96,95 \% \mathrm{Cl} 0.88$ to 1.04 ). 
Figure 3. Total mortality for all studies at their longest follow-up. Filled diamonds represent the risk ratio (RR) for individual studies at the longest reported follow-up. The boxes are proportional to the weight of each study in the analysis and the lines represent their $95 \%$ confidence interval $(\mathrm{CI})$. The open diamond represents the pooled $R R$, and its width represents its

95\% Cl.

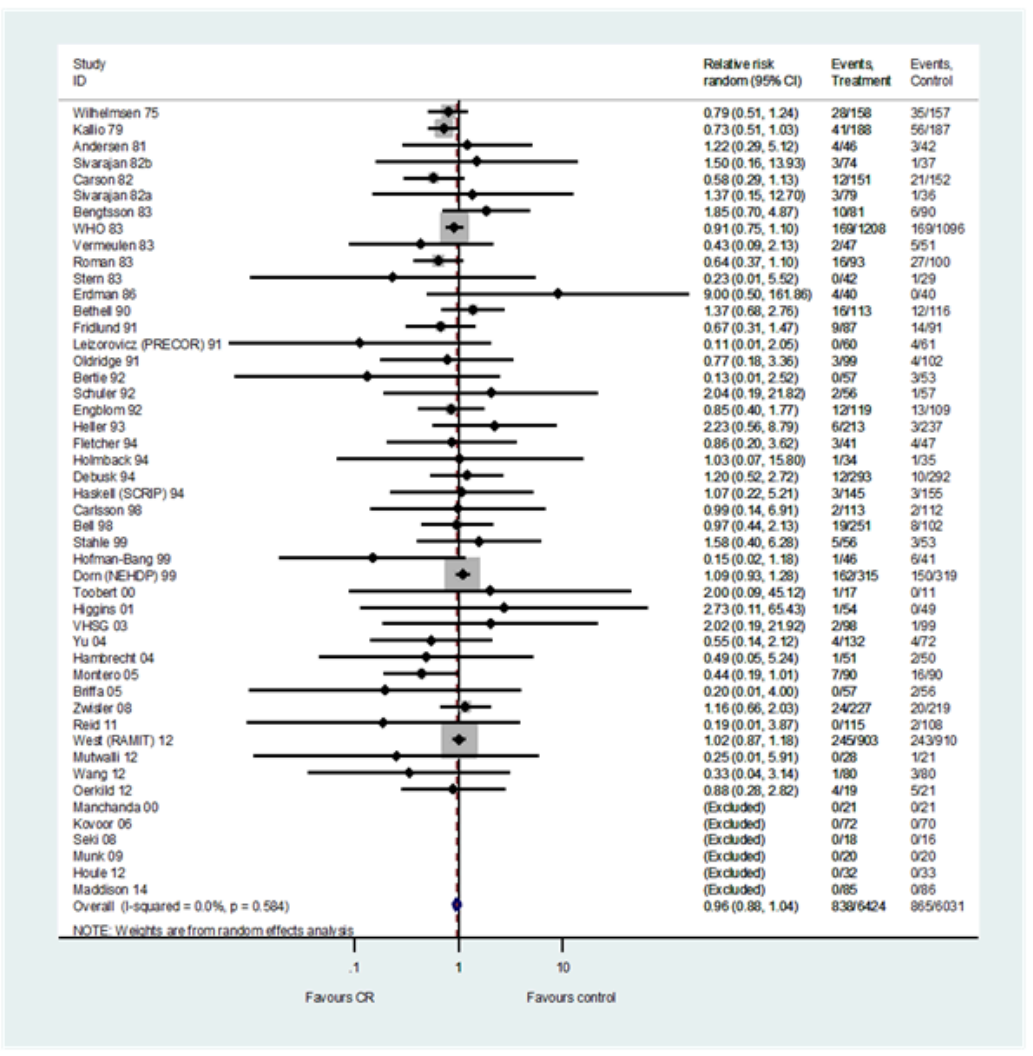

Twenty seven trials ( $\mathrm{N}=7469$ participants) reported cardiovascular mortality (Analysis 1.2, Figure 4). One trial reported both short- and medium-term follow-up (WHO 1983). While there was a reduction in cardiovascular mortality in the short-term (15 trials, RR 0.90 , $95 \% \mathrm{Cl} 0.69$ to 1.17 ) this only became statistically significant in the medium- (7 trials, RR $0.77,95 \% \mathrm{Cl} 0.63$ to 0.93 ) and long-term (8 trials, RR $0.58,95 \% \mathrm{Cl} 0.43$ to 0.78 ) follow-up. A reduction in cardiovascular mortality was also seen across all trials reporting this outcome ( 27 trials, RR $0.74,95 \% \mathrm{Cl} 0.64$ to 0.86 ). 
Figure 4. CV mortality for all studies at their longest follow-up. Filled diamonds represent the risk ratio (RR) for individual studies at the longest reported follow-up. The boxes are proportional to the weight of each study in the analysis and the lines represent their $95 \%$ confidence interval $(\mathrm{CI})$. The open diamond represents the pooled RR, and its width represents its

95\% Cl.

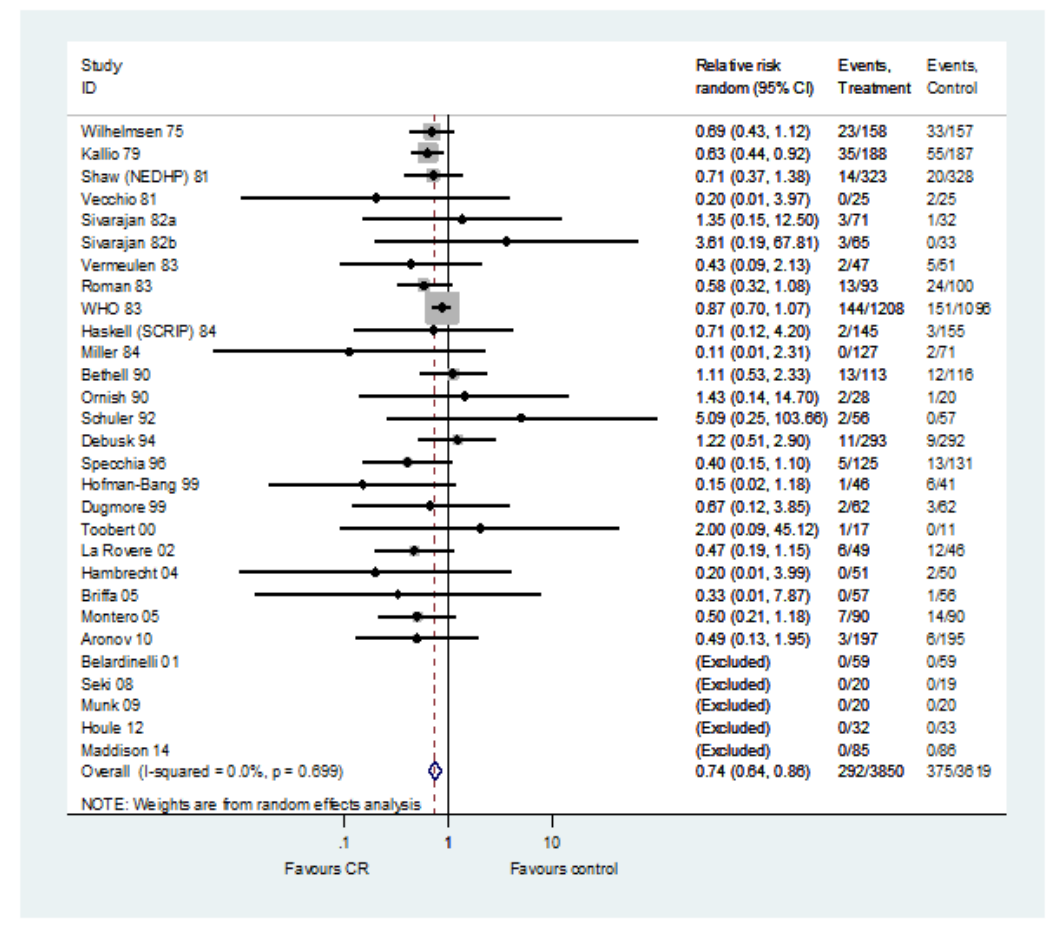

Twenty studies reported both mortality outcomes. Results for mortality outcomes in this sub-group were consistent with the overall meta-analysis results (all-cause mortality RR: $0.91,95 \% \mathrm{Cl}$ : 0.82 to 1.01 ; CV mortality RR: $0.78,95 \%$ : 0.67 to 0.90 ). There was no evidence of statistical heterogeneity across trials for either total or cardiovascular mortality.

\section{Myocardial infarctions}

Thirty six trials ( $N=9717$ participants) reported the risk of fatal or non-fatal MI (Analysis 1.3,Figure 5). Although there was no statistically significant difference in the risk of total $\mathrm{MI}$ in trials with follow-up in the short- ( 20 trials, RR $0.85,95 \% \mathrm{Cl} 0.67$ to 1.08 ) or medium-term (11 trials, RR $1.09,95 \% \mathrm{Cl} 0.91$ to 1.29 ), or across all trials reporting this outcome ( 36 trials, RR $0.90,95 \% \mathrm{Cl} 0.79$ to 1.04 ), there was evidence of a significant reduction in risk in studies with long-term follow-up ( 10 trials, RR $0.67,95 \% \mathrm{Cl} 0.50$ to 0.90 ). There was no evidence of statistical heterogeneity across trials. 
Figure 5. Fatal and / or nonfatal MI for all studies at their longest follow-up. Filled diamonds represent the risk ratio (RR) for individual studies at the longest reported follow-up. The boxes are proportional to the weight of each study in the analysis and the lines represent their $95 \%$ confidence interval $(\mathrm{CI})$. The open diamond represents the pooled $R R$, and its width represents its

$95 \% \mathrm{Cl}$.

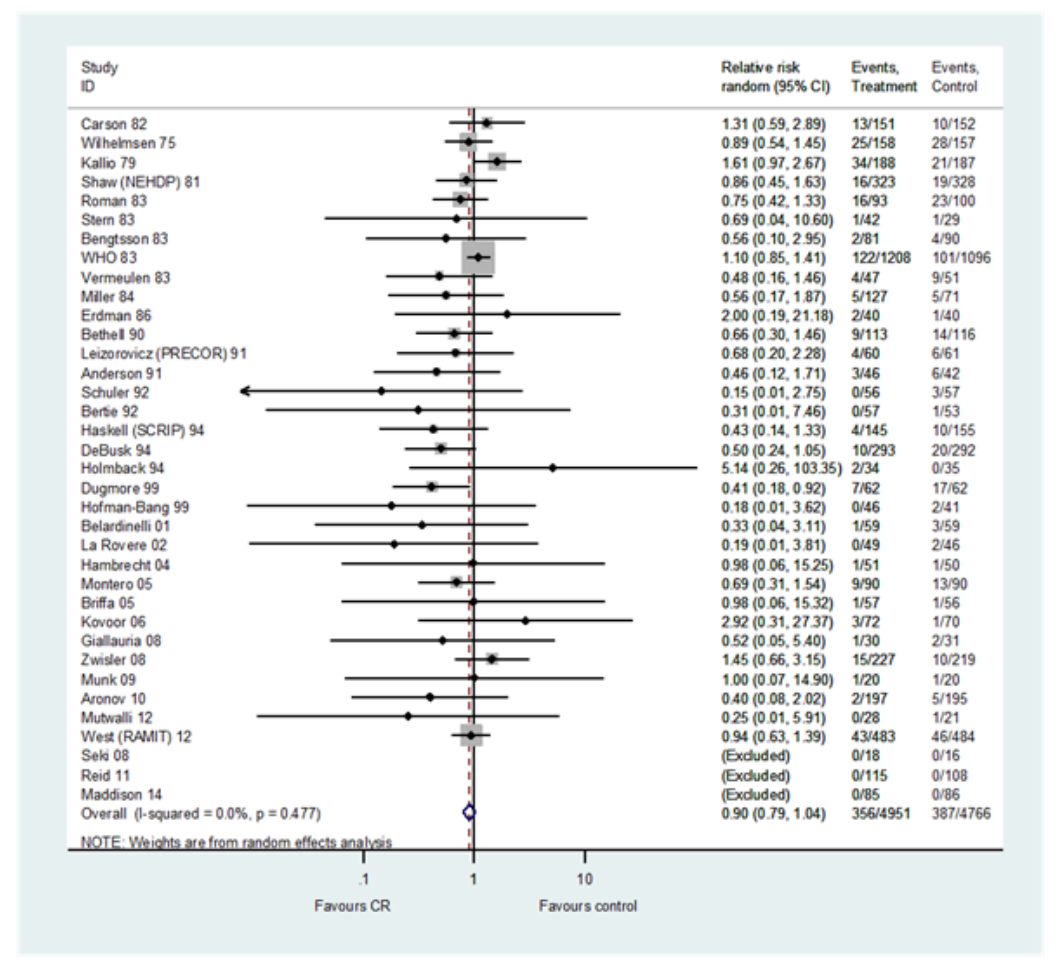

\section{Revascularisations}

Twenty nine ( $\mathrm{N}=5891$ participants), and 18 ( $\mathrm{N}=4012$ participants) of the included trials reported the risk of $C A B G$ and $\mathrm{PCl}$, respectively (Analysis 1.4, Figure 6; Analysis 1.5, Figure 7). There was no difference between exercise-based $\mathrm{CR}$ and usual care for either CABG or PCl in trials with short- (CABG: 21 trials, RR $0.99,95 \% \mathrm{Cl} 0.77$ to 1.26 ; $\mathrm{PCl}: 13$ trials, RR $0.92,95 \% \mathrm{Cl} 0.64$ to 1.33 ) or medium-term
(CABG: 8 trials, RR 0.98, 95\% Cl 0.78 to 1.25 ; PCl: 6 trials, RR 0.96, $95 \% \mathrm{Cl} 0.69$ to 1.35$)$ follow-up, or across all trials reporting these outcomes (CABG: 29 trials, RR 0.96, 95\% Cl 0.80 to 1.16 ; $\mathrm{PCl}$ : 18 trials, $\mathrm{RR} 0.85,95 \% \mathrm{Cl} 0.70$ to 1.04$)$. A reduction in revascularisation in the small number of trials reporting follow-up longer than 36 months did not reach statistical significance (CABG: 4 trials, RR $0.66,95 \% \mathrm{Cl}$ 0.34 to $1.27 ; \mathrm{PCl}: 3$ trials, RR $0.76,95 \% \mathrm{Cl} 0.48$ to 1.20 ). There was no evidence of major statistical heterogeneity across trials. 
Figure 6. CABG for all studies at their longest follow-up. Filled diamonds represent the risk ratio (RR) for individual studies at the longest reported follow-up. The boxes are proportional to the weight of each study in the analysis and the lines represent their $95 \%$ confidence interval (CI). The open diamond represents the pooled RR, and its width represents its

$95 \% \mathrm{Cl}$.

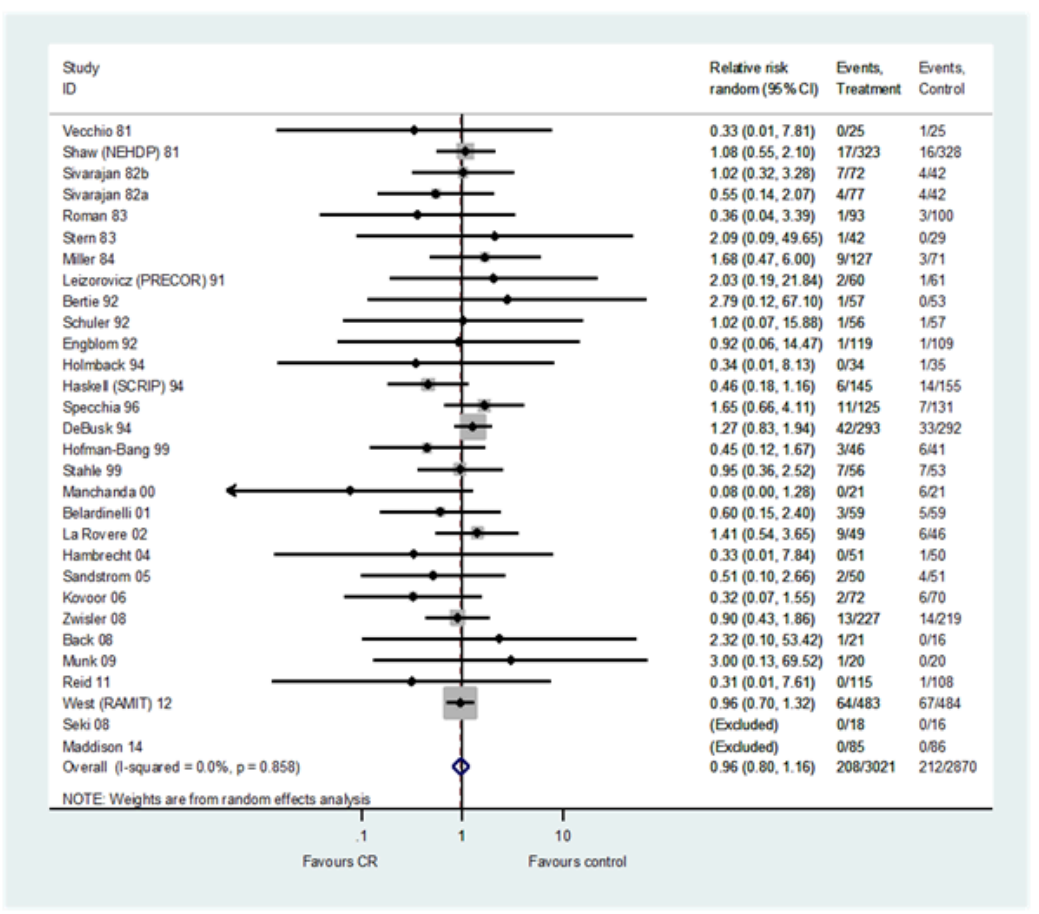


Figure 7. PCI for all studies at their longest follow-up. Filled diamonds represent the risk ratio (RR) for individual studies at the longest reported follow-up. The boxes are proportional to the weight of each study in the analysis and the lines represent their $95 \%$ confidence interval $(\mathrm{CI})$. The open diamond represents the pooled RR, and its width represents its

95\% Cl.

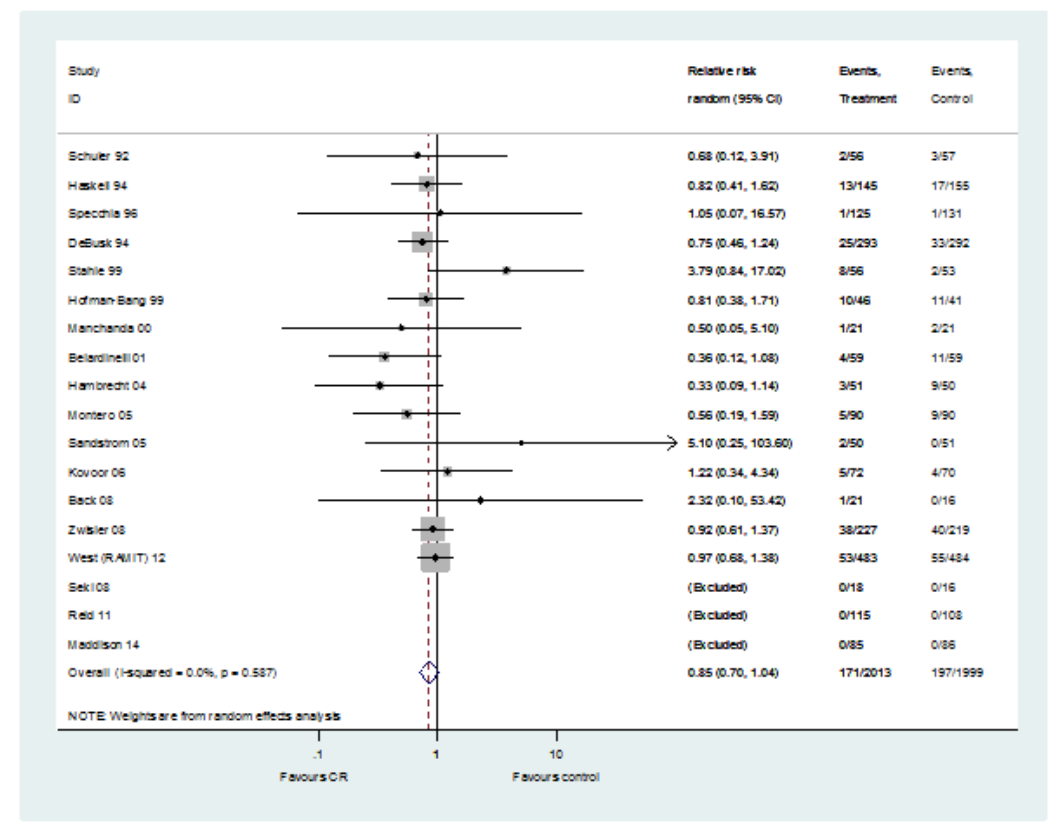

\section{Hospitalisations}

Fifteen ( $\mathrm{N}=3030$ participants) studies reported hospital admissions (Analysis 1.6, Figure 8). One study reported follow-up at both shortand medium-term (Hofman-Bang 1999). No trials with long-term follow-up reported data. Risk of hospital admissions was reduced with exercise-based CR compared with usual care in the short term (9 trials, RR $0.65,95 \% \mathrm{Cl} 0.46$ to 0.92 ) with no significant difference in trials with medium-term follow-up ( 6 trials, RR $0.95,95 \% \mathrm{Cl} 0.84$ to 1.07). A significant reduction in risk was seen across all trials reporting hospitalisations ( $\mathrm{RR} 0.82,95 \% \mathrm{Cl} 0.70$ to 0.96 ). 
Figure 8. Hospital admissions for all studies at their longest follow-up. Filled diamonds represent the risk ratio (RR) for individual studies at the longest reported follow-up. The boxes are proportional to the weight of each study in the analysis and the lines represent their $95 \%$ confidence interval (CI). The open diamond represents the pooled RR, and its width represents its

$95 \% \mathrm{Cl}$.

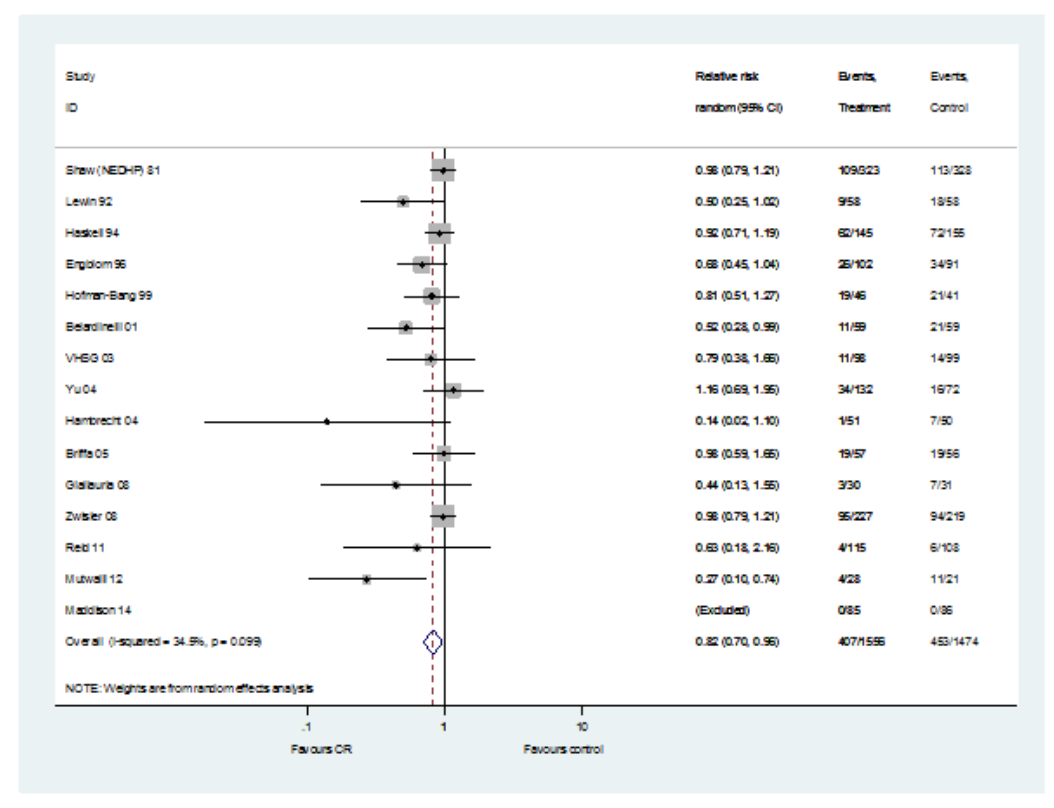

\section{Health-related quality of life}

Twenty trials ( $\mathrm{N}=5060$ participants) assessed HRQL using a range of validated generic (e.g. Short-Form 36) or diseasespecific (e.g. HeartQOL) outcome measures (Table 1). Given both the heterogeneity in HRQL outcome measures and methods of reporting findings, a meta-analysis was not undertaken. Although most trials demonstrated an improvement in $\mathrm{HRQL}$ at follow-up compared to baseline following exercise-based CR, a within-group improvement was also often reported in control patients. Fourteen out of the 20 trials reported higher levels of quality of life in one or more sub-scale with exercise-based CR compared with control at follow-up (Belardinelli 2001; Bell 1998; Bettencourt 2005; Briffa 2005; Engblom 1996; Heller 1993; Hofman-Bang 1999; Houle 2012; Maddison 2014; Mutwalli 2012; Reid 2012; Toobert 2000; Wang 2012; Yu 2003), and in five trials there was evidence of a significantly higher level of quality of life in half or more $(\geq 50 \%)$ of the sub-scales (Belardinelli 2001; Bell 1998; Mutwalli 2012; Reid 2012; Wang 2012).

\section{Costs and cost-effectiveness}

Seven of the included studies reported data on costs of CR and overall healthcare costs in both groups (Briffa 2005; Hambrecht 2004; Kovoor 2006; Maddison 2014; Marchionni 2003; Oldridge 1991; Yu 2004). These results are summarised in Table 2. While it was not possible to directly compare costs across studies due to differences in currencies and the timing of studies, it is possible to compare the within-study costs for CR and control groups. Three studies showed no difference in total healthcare costs between groups, (Briffa 2005; Kovoor 2006; Yu 2004), one study found healthcare costs for rehabilitation lower (USD 2378 less per patient) compared to control (Hambrecht 2004), and the remaining three did not report a p-value for the cost difference (Maddison 2014; Marchionni 2003; Oldridge 1991).

Four studies (Briffa 2005; Maddison 2014; Oldridge 1991; Yu 2004) also reported cost-effectiveness using a cost utility approach (i.e. cost per quality-adjusted life year (QALY). The incremental cost ratio ranged from an additional cost with CR compared to control of USD 42,535 more per QALY (Briffa 2005) to a reduction in cost of USD 650 less per QALY (Yu 2004). Based on these analyses, authors 
consistently concluded CR to be a cost-effective use of healthcare resources compared to usual care.

\section{Meta-regression}

Predictors of total mortality, cardiovascular mortality, recurrent $\mathrm{MI}$, revascularisation (CABG and $\mathrm{PCl}$ ) and hospitalisation were examined across the longest follow-up of each individual study, using univariate meta-regression. No statistically significant associations were seen in any of the analyses (Table 3, Table 4, Table 5, Table 6, Table 7, Table 8).

\section{Small study bias}

There was no evidence of funnel plot asymmetry or statistically significant Egger tests for total mortality, cardiovascular mortality or risk of revascularisation. However, the Egger test was statistically significant for $\mathrm{MI}(\mathrm{P}=0.009)$ and hospitalisation admission $(\mathrm{P}=$ 0.001 ) suggesting funnel plot asymmetry, which appears to be due to an absence of negative-result trials of small to medium size (Figure 9; Figure 10).

Figure 9. Funnel plot of comparison: 1 Exercise-based rehabilitation versus usual care, outcome: 1.3 Fatal and/or nonfatal MI.

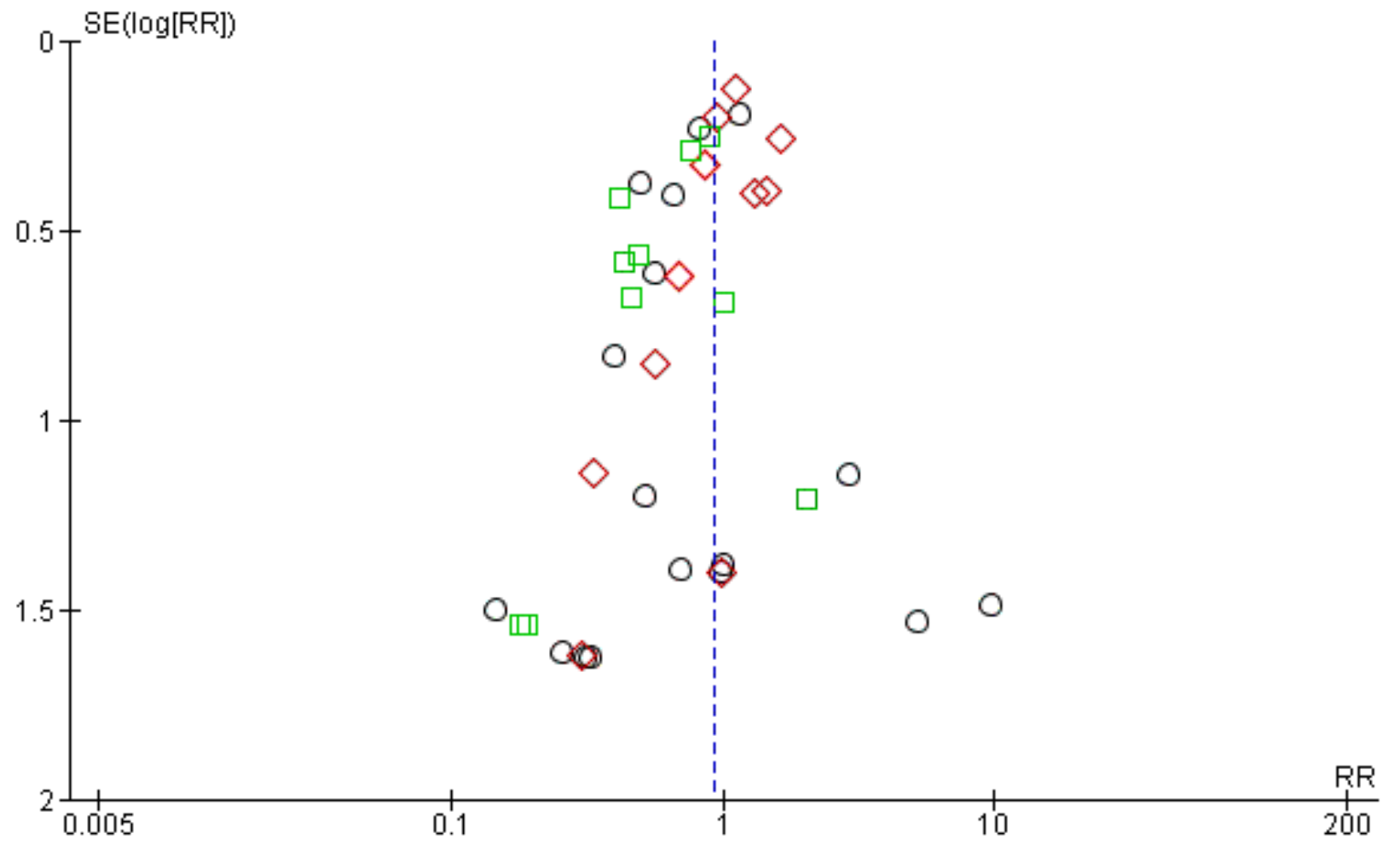

Subgroups

Follow-up of 6 to 12 months

Follow-up of longer than 3 years

Follow-up of $>12$ to 36 months 
Figure 10. Funnel plot of comparison: 1 Exercise-based rehabilitation versus usual care, outcome: 1.6 Hospital admissions.

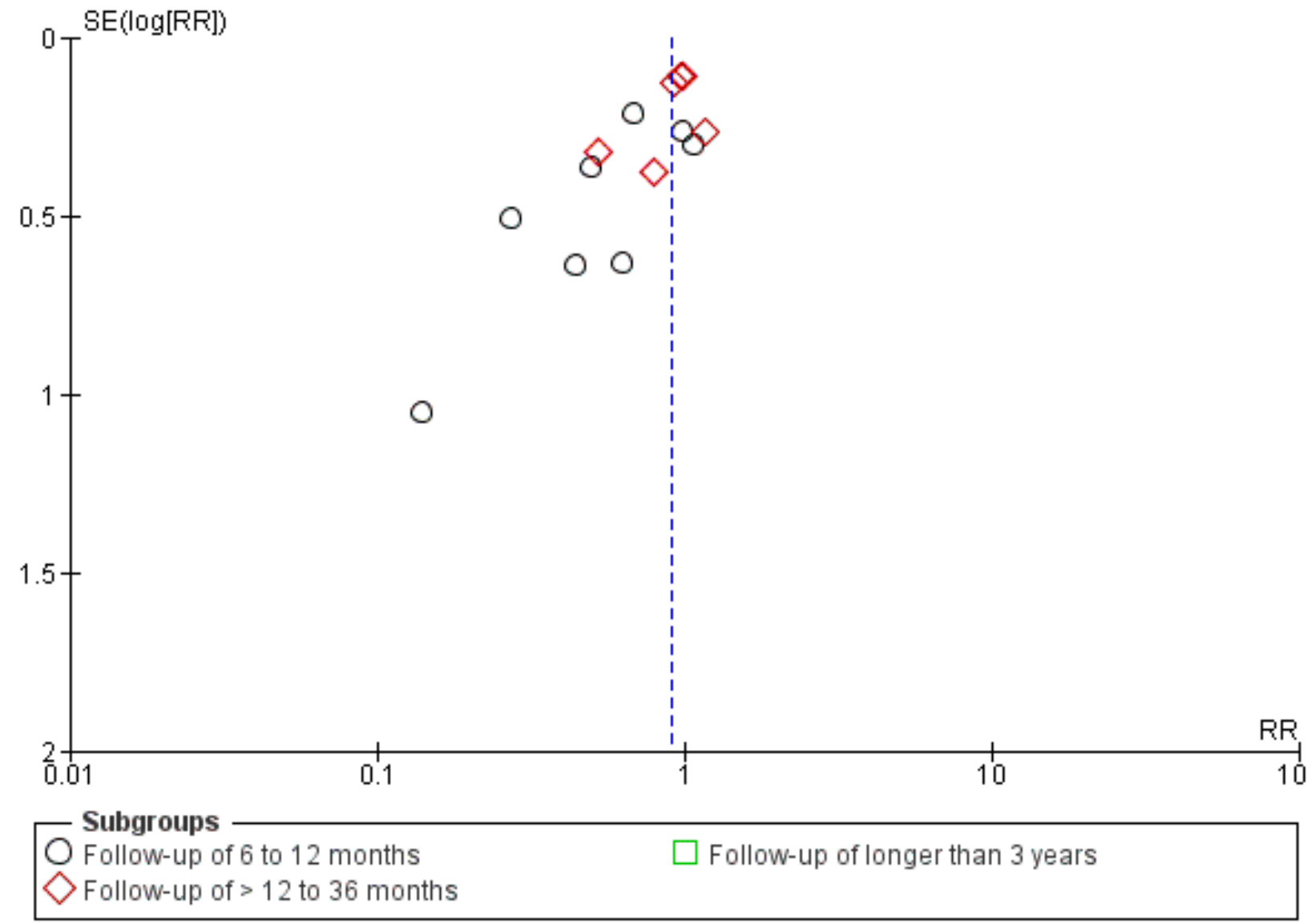

\section{Quality of evidence from randomised controlled trials}

The quality of the evidence for outcomes reported in the review was rated using the GRADE method (Schünemann 2011). The quality of the evidence varied widely by outcome and ranged from low to moderate (Summary of findings for the main comparison). The evidence of all outcomes in all followup categories was downgraded due to poor reporting of random sequence generation, allocation concealment or blinding of outcome assessors in at least $50 \%$ of the studies which contributed data to the evidence. In addition, some outcomes were downgraded for evidence of publication bias.

\section{DISCUSSION}

\section{Summary of main results}

We stratified the clinical event outcomes in this update by length of follow-up. However, as we found no significant difference in the impact of exercise-based CR on clinical outcomes across follow-up, we focused on reporting the findings pooled across all trials at longest follow-up (median 12 months). Exercise-based CR significantly reduced cardiovascular mortality, but not total mortality, compared with no exercise control. The risk of hospital admissions was reduced with exercise-based $C R$, but there was no significant impact on the risk of $\mathrm{MI}, \mathrm{CABG}$ or $\mathrm{PCl}$. Univariate meta-regression analysis shows that the impact of exercise-based
CR on clinical events appears to be largely consistent across trials irrespective of case mix (percentage of post-MI participants), type of rehabilitation (exercise-only vs comprehensive), dose of exercise training, duration of follow-up, study location, risk of bias or sample size. Although meta-analysis was not undertaken for HRQL outcomes (due to the range of outcome measures and methods of reporting), there was evidence of significantly higher levels of HRQL with exercise-based CR than with usual care across a number of trials. The four trial-based economic evaluation studies showed exercise-based CR to be a potentially cost-effective use of resources in terms of gain in QALYs. The majority of participants included in this review were post-MI or post-revascularisation. More recent trials have recruited a greater proportion of female and older patients and some have employed technologies such as pedometers, the internet or mobile phones as a means of encouraging activity amongst participants.

\section{Overall completeness and applicability of evidence}

The generalisability of the previous version of this review was limited as most included studies recruited predominantly younger men following MI or revascularisation. However, with the inclusion of more women and older participants in recent trials, and further data on the outcomes of hospitalisation and HRQL, the findings of this updated review potentially have greater external validity. 


\section{Quality of the evidence}

The general lack of reporting of methods in the included RCT reports made it difficult to assess their methodological quality and thereby judge their risk of bias. Largely due to this poor reporting, the quality of the evidence for all outcomes was evaluated as moderate at best. However, there appeared to be improvement in the quality of reporting in more recent trials. Several trials excluded significant numbers of patients post-randomisation, and thus in an intention-to-treat analysis, these patients have been regarded as dropouts. This may be partly explained by the fact that the majority of trials were not designed to assess treatment group differences in mortality and morbidity outcome but instead surrogate measures of treatment outcome, such as exercise capacity or risk factor levels. Reassuringly, meta-regression showed no significant association between the effect of CR compared to control and the level of risk of bias across trials.

\section{Potential biases in the review process}

We believe this is the most comprehensive systematic review to date of RCT-based evidence for the impact of exercise-based CR for people with CHD. However, our review has some limitations. Funnel plot asymmetry for the risk of $\mathrm{MI}$ and hospital admission is indicative of small-study bias and possible publication bias. Although a specific goal of this updated review was to clarify the impact of exercise training programmes on clinical events, many of the included trials were relatively small and of shortterm follow-up so that the number of deaths and hospitalisations reported by most trials was small. Indeed, in many studies, we located event data in the trial descriptions of losses to followup and exclusions, rather than as stated primary or secondary outcomes. We also acknowledge that the median outcome followup of 12 months is limited when assessing for impact on mortality and morbidity outcome measures. However, our results were consistent when pooling was limited to RCTs with a follow up $>12$ months. In this updated review, we also sought to categorise the $\mathrm{CHD}$ diagnoses of trial participants according to a more detailed framework developed by one of the review team (ADZ) based on Braunwald's classification of CHD (Braunwald 2011) and current clinical management of CHD. However, given the lack of details of the patients included in the trials, this more detailed assessment of diagnostic groups did not prove possible. All participants in the included studies had documented CHD, the majority of the participants having suffered an MI or undergone revascularisation. As with the previous versions of this review, we have combined these different patient groups as there are insufficient data at present to stratify trials by type of CHD.

\section{Agreements and disagreements with other studies or reviews}

The findings of this updated review are largely in accord with the previous version of this review. However, unlike the 2011 review, although there was a trend towards a reduction in total mortality with exercise-based CR compared to no exercise control, this reduction failed to reach statistical significance. This is likely to be explained by the inclusion of more recent trials of mixed CHD populations which have been conducted in the era of optimal medical therapy. Given the proven survival advantage of contemporary medical treatments, and the limited opportunity for mortality gain in this patient cohort, any incremental total mortality benefit with exercise is likely to be small.

\section{AUTHORS' CONCLUSIONS}

\section{Implications for practice}

This review shows that while exercise-based CR does not reduce total mortality, it does provide important benefits by reducing cardiovascular mortality and hospitalisation (and associated healthcare costs), and improving HRQL in younger men who have suffered MI or are post-revascularisation. While there was an increase in the proportion of female and older individuals in more recent trials, the application of this evidence base to a more poorly represented group, particularly angina pectoris and higher risk CHD patients, and those with major co-morbidities, remains a question of clinical judgement. There appears to be little to choose between exercise-only or exercise in combination with psychosocial or educational CR interventions. In the absence of definitive costeffectiveness comparing psychosocial or educational approaches to exercise-based CR, it would be rational to use cost considerations to determine practice.

\section{Implications for research}

In spite of incorporation of recent trial evidence including more older and female patients, the population of CHD patients studied in this review update remains predominately low risk middle-aged males following MI or revascularisation. Therefore, well-designed, and adequately reported RCTs of CR in groups of CHD patients more representative of usual clinical practice are still needed. These trials should include validated HRQL outcome measures, need to explicitly report clinical events including mortality and hospital admission, and assess costs and cost-effectiveness. Furthermore, further details of the presentation and diagnoses of CHD participants and interventions offered and received should be reported in trials, so that results of future reviews can better stratify outcomes according to the range of $\mathrm{CHD}$ populations or types of $\mathrm{CR}$ interventions.

\section{ACK N O WLEDGEMENTS}

We would like to thank Zhivko Zhelev, Shenqiu Zhang and Oriana Ciani for their translation services, and Harriot Hunt for her assistance with screening titles and abstracts. We would also like to thank all the authors who provided additional information about their trials. Finally we would like to acknowledge the support of coauthors on the two previous versions of this review. 


\section{R E F E R E N C E S}

\section{References to studies included in this review}

\section{Andersen 1981 \{published data only\}}

Andersen GS, Christiansen P, Madsen S, Schmidt G. The value of regular, supervised physical training after acute myocardial infarction [Vaerdien af regelmaessig og overvåget fysisk traening efter akut myokardieinfarkt.]. Ugeskrift for Laeger 1981;143(45):2952-5.

\section{Aronov 2010 \{published data only\}}

Aronov DM, Krasnitskij VB, Bubnova MG. Efficacy of physical training and analysis of lipid-lowering therapy in patients with ischemic heart disease after acute coronary incidents. Rational Pharmacotherapy Cardiology 2010; Vol. 6, issue 1:9-19.

\section{Bäck 2008 \{published data only\}}

Bäck M, Wennerblom B, Wittboldt S, Cider A. Effects of high frequency exercise in patients before and after elective percutaneous coronary intervention. European Journal of Cardiovascular Nursing 2008;7(4):307-13.

\section{Belardinelli 2001 \{published data only\}}

Belardinelli R, Paolini I, Cianci G, Piva R, Georgiou D, Purcaro A. Exercise training intervention after coronary angioplasty: The ETICA Trial. Journal of the American College of Cardiology 2001;37(7):1891-900.

\section{Bell 1998 \{unpublished data only\}}

Bell JM. A comparison of a multi-disciplinary home based cardiac rehabilitation programme with comprehensive conventional rehabilitation in post-myocardial infarction patients. PhD Thesis, University of London 1998.

\section{Bengtsson 1983 \{published data only\}}

Bengtsson K. Rehabilitation after myocardial infarction. Scandinavian Journal of Rehabilitation Medicine 1983;15(1):1-9.

\section{Bertie 1992 \{published data only\}}

Bertie J, King A, Reed N, Marshall AJ, Ricketts C. Benefits and weaknesses of a cardiac rehabilitation programme. Journal of the Royal College of Physicians of London 1992;26(2):147-51.

\section{Bethell 1990 \{published and unpublished data\}}

Bethell HJN, Mullee MA. A controlled trial of community based coronary rehabilitation. British Heart Journal 1990;64(6):370-5

\section{Bettencourt 2005 \{published data only\}}

Bettencourt N, Dias C, Mateus P, Sampaio F, Santos L, Adao L, et al. Impact of cardiac rehabilitation on quality of life and depression after acute coronary syndrome [Impacto da reabilitacao cardiaca na qualidade-de-vida e sintomatologia depressiva apos sindroma coronaria aguda]. Revista Portuguesa de Cardiologia 2005;24:687-96.

\section{Briffa 2005 \{published data only\}}

Briffa TG, Eckermann SD, Griffiths AD, Harris PJ, Heath MR, Freedman SB, et al. Cost-effectiveness of rehabilitation after an acute coronary event: a randomised controlled trial. Medical Journal of Australia 2005;183:450-5.

\section{Carlsson 1998 \{published data only\}}

Carlsson R. Serum cholesterol, lifestyle, working capacity and quality of life in patients with coronary artery disease. Experiences from a hospital-based secondary prevention programme. Scandinavian Cardiovascular Journal. Supplement 1998;50:1-20.

\section{Carson 1982 \{published data only\}}

Carson P, Phillips R, Lloyd M, Tucker H, Neophytou M, Buch NJ, et al. Exercise after myocardial infarction: a controlled trial. Journal of the Royal College of Physicians of London 1982;16(3):147-51.

\section{DeBusk 1994 \{published data only\}}

* DeBusk RF, Miller NH, Superko HR, Dennis CA, Thomas RJ, Lew $\mathrm{HT}$, et al. A case management system for coronary risk factor modification following acute myocardial infarction. Annals of Internal Medicine 1994;120(9):721-9.

Taylor CB, Miller NH, Smith PM, DeBusk RF. The effect of a home-based, case-managed, multifactorial risk-reduction program on reducing psychological distress in patients with cardiovascular disease. Journal of Cardiopulmonary Rehabilitation 1997;17(3):157-62.

\section{Dorn 1999 \{published data only\}}

Dorn J, Naughton J, Imamura D, Trevisan M. Results of a multicenter randomized clinical trial of exercise and longterm survival in myocardial infarction patients: the National Exercise and Heart Disease Project (NEHDP). Circulation 1999;100:1764-9.

\section{Dugmore 1999 \{published data only\}}

Dugmore LD, Tipson RJ, Phillips MH, Flint EJ, Stentiford NH, Bone MF, et al. Changes in cardiorespiratory fitness, psychological wellbeing, quality of life, and vocational status following a 12 month cardiac exercise rehabilitation programme. Heart 1999;81(4):359-66.

Engblom 1996 \{published data only\}

Engblom E, Hamalainen H, Lind J, Mattlar CE, Ollila S, Kallio V, et al. Quality of life during rehabilitation after coronary bypass surgery. Quality of Life Research 1992;1:167-75. [MEDLINE: 93244729]

Engblom E, Hietanen EK, Hamalainen H, Kallio V, Inberg M, Knuts L-R. Exercise habits and physical performance during comprehensive rehabilitation after coronary artery bypass surgery. European Heart Journal 1992;13:1053-9. [MEDLINE: 92209581]

* Engblom E, Korpilahti K, Hamalainen H, Puukka P, Ronnemaa T. Effects of five years of cardiac rehabilitation after coronary artery bypass grafting on coronary risk factors. American Journal of Cardiology 1996;78:1428-31. [MEDLINE: 97125341]

Engblom E, Korpilahti K, Hamalainen H, Ronnemaa T, Puukka P. Quality of life and return to work 5 years after coronary artery 
bypass surgery. Journal of Cardiopulmonary Rehabilitation 1997;17:29-36. [MEDLINE: 97193477]

Engblom E, Rönnemaa T, Hämäläinen H, Kallio V, Vänttinen, Knuts LR. Coronary heart disease risk factors before and after bypass surgery: results of a controlled trial on multifactorial rehabilitation. European Heart Journal 1992;13(2):232-7. [MEDLINE: 92209581]

\section{Erdman 1986 \{published data only\}}

Erdman RAM, Duivenvoorden HJ, Verhage F, Kazemier M, Hugenholtz PG. Predictability of beneficial effects in cardiac rehabilitation: A randomized clinical trial of psychosocial variables. Journal of Cardiopulmonary Rehabilitation 1986;6(6):206-13.

\section{Fletcher 1994 \{published data only\}}

Fletcher BJ, Dunbar SB, Felner JM, Jensen BE, Almon L, Cotsonis $\mathrm{G}$, et al. Exercise testing and training in physically disabled men with clinical evidence of coronary artery disease. American Journal of Cardiology 1994;73(2):170-4.

\section{Fridlund 1991 \{published data only\}}

* Fridlund B, Högstedt B, Lidell E, Larsson PA. Recovery after myocardial infarction: Effects of a caring rehabilitation programme. Scandinavian Journal of Caring Sciences 1991;5(1):23-32.

Fridlund B, Lidell E, Larsson PA. A caring perspective on rehabilitation after myocardial infarction: A theoretical framework and a suggestion for a rehabilitation programme. Scandinavian Journal of Caring Sciences 1989;3(3):129-35.

Fridlund B, Pihilgren C, Wannestig LB. A supportive - educative caring rehabilitation programme: improvements of physical health after myocardial infarction. Journal of Clinical Nursing 1992;1:141-6.

Lidell E, Fridlund B. Long-term effects of a comprehensive rehabilitation programme after myocardial infarction. Scandinavian Journal of Caring Sciences 1996;10:67-74.

\section{Giallauria 2008 \{published data only\}}

Giallauria F, Cirillo P, Lucci R, Pacileo M, De Lorenzo A, D'Agostino $M$, et al. Left ventricular remodelling in patients with moderate systolic dysfunction after myocardial infarction: favourable effects of exercise training and predictive role of $\mathrm{N}$-terminal pro-brain natriuretic peptide. European Journal of Cardiovascular Prevention and Rehabilitation 2008;15(1):113-8.

\section{Hambrecht 2004 \{published data only\}}

* Hambrecht R, Walther C, Mobius-Winkler S, Gielen S, Linke A, Conradi K, et al. Percutaneous coronary angioplasty compared with exercise training in patients with stable coronary artery disease: a randomized trial. Circulation 2004;109:1371-8.

Walther C, Mobius-Winkler S, Linke A, Bruegel M, Thiery J, Schuler $\mathrm{G}$, et al. Regular exercise training compared with percutaneous intervention leads to a reduction of inflammatory markers and cardiovascular events in patients with coronary artery disease. Eur J Cardiovasc Prev Rehabil 2008;15:107-12.

\section{Haskell 1994 \{published data only\}}

Haskell WL, Alderman EL, Fair JM, Maron DJ, Mackey SF, Superko HR, et al. Effects of intensive multiple risk factor reduction on coronary atherosclerosis and clinical cardiac events in men and women with coronary artery disease: The Stanford Coronary Risk Intervention Project (SCRIP). Circulation 1994;89(3):975-90.

\section{Heller 1993 \{published data only\}}

Heller RF, Knapp JC, Valenti LA, Dobson AJ. Secondary prevention after acute myocardial infarction. American Journal of Cardiology 1993;72(11):759-62.

Higgins 2001 \{published data only\}

Higgins H C, Hayes R L, McKenna K T. Rehabilitation outcomes following percutaneous coronary interventions ( $\mathrm{PCI})$. Patient Education \& Counseling 2001;43:219-30.

\section{Hofman-Bang 1999 \{published data only\}}

Hofman-Bang C, Lisspers J, Nordlander R, Nygren Å, Sundin Ö, Öhman A, et al. Two-year results of a controlled study of residential rehabilitation for patients treated with percutaneous transluminal coronary angioplasty. A randomized study of a multifactorial programme. European Heart Journal 1999;20(20):1465-74.

* Lisspers J, Sundin Ö, Hofman-Bang C, Nordlander R, Nygren $\AA$, Rydén $L$, et al. Behavioral effects of a comprehensive multifactorial program for lifestyle change after percutaneous transluminal coronary angioplasty: A prospective randomized, controlled study. Journal of Psychosomatic Research 1999;46(2):143-54.

Lisspers J, Sundin Ö, Öhman A, Hofman-Bang C, Rydén L, Nygren $\AA$. Long-term effects of lifestyle behavior change in coronary artery disease: Effects on recurrent coronary events after percutaneous coronary intervention. Health Psychology 2005;24(1):41-8.

\section{Holmbäck 1994 \{published data only\}}

Holmbäck AM, Säwe U, Fagher B. Training after myocardial infarction: Lack of long-term effects on physical capacity and psychological variables. Archives of Physical Medical and Rehabilitation 1994;75(5):551-4.

\section{Houle 2012 \{published data only\}}

Houle J, Doyon O, Vadeboncoeur N, Turbide G, Diaz A, Poirier P. Effectiveness of a pedometer-based program using a sociocognitive intervention on physical activity and quality of life in a setting of cardiac rehabilitation. Canadian Journal of Cardiology 2012;28:27-32.

\section{Kallio 1979 \{published data only\}}

Kallio V, Hämäläinen $\mathrm{H}$, Hakkila J, Luurila OJ. Reduction in sudden deaths by a multifactorial intervention programme after acute myocardial infarction. Lancet 1979;2(8152):1091-4.

\section{Kovoor 2006 \{published data only\}}

Hall JP, Wiseman VP, King MT, Ross DL, Kovoor P, Zecchin RP, et al. Economic Evaluation of a Randomised Trial of Early Return to Normal Activities Versus Cardiac Rehabilitation After 
Acute Myocardial Infarction. Heart, Lung and Circulation 2002 2002;11:10-18.

Kovoor P, Lee AKY, Carrozzi F, Wiseman V, Byth K, Zecchin R, et al. Return to full normal activities including work at two weeks after acute myocardial infarction. American Journal of Cardiology 2006;97(7):952-8.

\section{La Rovere 2002 \{published data only\}}

La Rovere MT, Bersano C, Gnemmi M, Specchia G, Schwartz PJ. Exercise-induced increase in baroreflex sensitivity predicts improved prognosis after myocardial infarction. Circulation 2002;106(8):945-9.

\section{Leizorovicz 1991 \{published data only\}}

Leizorovicz A, Saint-Pierre A, Vasselon C, Boissel JP. Comparison of a rehabilitation programme, a counselling programme and usual care after an acute myocardial infarction: Results of a long-term randomized trial. P.RE.COR. Group. European Heart Journal 1991;12(5):612-6.

\section{Lewin 1992 \{published data only\}}

Lewin B, Robertson IH, Cay EL, Irving JB, Campbell M. Effects of self-help post-myocardial infarction rehabilitation on psychological adjustment and use of health services. Lancet 1992;339(8800):1036-40.

\section{Maddison 2014 \{published data only\}}

Maddison R, Pfaeffli L, Whittaker R, Stewart R, Kerr A, Jiang Y, et al. A mobile phone intervention increases physical activity in people with cardiovascular disease: Results from the HEART randomized controlled trial. European Journal of Preventive Cardiology 2014;22(6):701-9. [DOI: 10.1177/2047487314535076]

\section{Manchanda 2000 \{published data only\}}

Manchanda SC, Narang R, Reddy KS, Sachdeva U, Prabhakaran D, Dharmanand S, et al. Retardation of coronary atherosclerosis with yoga lifestyle intervention. Journal of the Association of Physicians of India 2000;48(7):687-94.

\section{Marchionni 2003 \{published data only\}}

Marchionni N, Fattirolli F, Fumagalli S, Oldridge N, Del Lungo F, Morosi L, et al. Improved exercise tolerance and quality of life with cardiac rehabilitation of older patients after myocardial infarction: Results of a randomized, controlled trial. Circulation 2003;107(17):2201-6.

\section{Maroto 2005 \{published data only\}}

Maroto MJM, Artigao Ramirez R, Morales Duran MD, de Pablo Zarzosa C, Abraira V. Cardiac rehabilitation in patients with myocardial infarction: a 10-year follow-up study. Revista Espanola de Cardiologia 2005;58:1181-7.

\section{Miller 1984 \{published data only\}}

DeBusk RF, Haskell WL, Miller NH, Berra K, Taylor CB, Berger WE, et al. Medically directed at-home rehabilitation soon after clinically uncomplicated acute myocardial infarction: a new model for patient care. American Journal of Cardiology 1985;55(4):251-7.
* Miller NH, Haskell WL, Berra K, DeBusk RF. Home versus group exercise training for increasing functional capacity after myocardial infarction. Circulation 1984;70(4):645-9.

Taylor CB, Houston-Miller N, Ahn DK, Haskell WL, DeBusk RF. The effects of exercise training programs on psychosocial improvement in uncomplicated postmyocardial infarction patients. Journal of Psychosomatic Research 1986;30(5):581-7.

Taylor CB, Houston-Miller N, Haskell WL, DeBusk RF. Smoking cessation after acute myocardial infarction: The effects of exercise training. Addictive Behaviors 1988;13(4):331-5.

\section{Munk 2009 \{published data only\}}

Munk PS, Breland UM, Aukrust P, Ueland T, Kvaloy JT, Larsen AI. High intensity interval training reduces systemic inflammation in post- $\mathrm{PCl}$ patients. European Journal of Cardiovascular Prevention \& Rehabilitation 2011;18:850-7.

Munk PS, Staal EM, Butt N, Isaksen K, Larsen Al. High-intensity interval training may reduce in-stent restenosis following percutaneous coronary intervention with stent implantation. American Heart Journal 2009;158:734-41.

\section{Mutwalli 2012 \{published data only\}}

Mutwalli HA, Fallows SJ, Arnous AA, Zamzami MS. Randomized controlled evaluation shows the effectiveness of a homebased cardiac rehabilitation program. Saudi Medical Journal 2012;33:152-9.

\section{Oerkild 2012 \{published data only\}}

Oerkild B, Frederiksen M, Hansen J F, Prescott E. Homebased cardiac rehabilitation is an attractive alternative to no cardiac rehabilitation for elderly patients with coronary heart disease: results from a randomised clinical trial. BMJ Open 2012;2:e001820.

\section{Oldridge 1991 \{published and unpublished data\}}

Oldridge N, Furlong W, Feeny D, Torrance G, Guyatt G Crowe J, Jones N. Economic Evaluation of Cardiac Rehabilitation Soon After Acute Myocardial Infarction. THe American Journal of Cardiology 1993;72:154-161.

* Oldridge N, Guyatt G, Jones N, Crowe J, Singer J, Feeny D, et al. Effects on quality of life with comprehensive rehabilitation after acute myocardial infarction. American Journal of Cardiology 1991;67(13):1084-9.

Oldridge N, Streiner D, Hoffmann R, Guyatt G. Profile of mood states and cardiac rehabilitation after acute myocardial infarction. Medicine and Science in Sports and Exercise 1995;27(6):900-5.

\section{Ornish 1990 \{published data only\}}

* Ornish D, Brown SE, Scherwitz LW, Billings JH, Armstrong WT, Ports TA, et al. Can lifestyle changes reverse coronary heart disease? The Lifestyle Heart Trial. Lancet 1990;336(8708):129-33.

Ornish D, Scherwitz LW, Billings JH, Brown SE, Gould KL, Merritt TA, et al. Intensive lifestyle changes for reversal of coronary heart disease. JAMA 1998;280(23):2001-7. 
Pischke CR, Scherwitz L, Weidner G, Ornish D. Long-term effects of lifestyle changes on well-being and cardiac variables among coronary heart disease patients. Health Psychology 2008;27(5):584-92.

\section{Reid 2012 \{published data only\}}

Reid DR, Morrin LI, Beaton LJ, Papadakis S, Kocourek J, McDonnell $\mathrm{L}$, et al. Randomized trial of an internet-based computer-tailored expert system for physical activity in patients with heart disease. European Journal of Preventive Cardiology 2012;19(6):1357-1364.

\section{Roman 1983 \{published data only\}}

Roman O, Gutierrez M, Luksic I, Chavez E, Camuzzi AL, Villalon E, et al. Cardiac rehabilitation after acute myocardial infarction. 9year controlled follow-up study. Cardiology 1983;70:223-31.

\section{Sandström 2005 \{published data only\}}

Sandström L, Ståhle A. Rehabilitation of elderly with coronary heart disease - Improvement in quality of life at a low cost. Advances in physiotherapy 2005;7:60-6.

\section{Schuler 1992 \{published data only\}}

Hambrecht R, Niebauer J, Marburger C, Grunze M, Kalberer B, Hauer K, et al. Various intensities of leisure time physical activity in patients with coronary artery disease: Effects on cardiorespiratory fitness and progression of coronary atherosclerotic lesions. Journal of the American College of Cardiology 1993;22(2):468-77.

Niebauer J, Hambrecht R, Marburger C, Hauer K, Velich T, von Hodenberg E, et al. Impact of intensive physical exercise and low-fat diet on collateral vessel formation in stable angina pectoris and angiographically confirmed coronary artery disease. American Journal of Cardiology 1995;76(11):771-5.

Niebauer J, Hambrecht R, Velich T, Hauer K, Marburger C, Kalberer $\mathrm{B}$, et al. Attenuated progression of coronary artery disease after 6 years of multifactorial risk intervention: role of physical exercise. Circulation 1997;96(8):2534-41.

Niebauer J, Hambrecht R, Velich T, Marburger C, Hauer K, Kreuzer J, et al. Predictive value of lipid profile for salutary coronary angiographic changes in patients on a low-fat diet and physical exercise program. American Journal of Cardiology 1996;78(2):163-7.

Nikolaus T, Schlierf G, Vogel G, Schuler G, Wagner I. Treatment of coronary heart disease with diet and exercise: problems of compliance. Annals of Nutrition and Metabolism 1991;35:1-7.

* Schuler G, Hambrecht R, Schlierf G, Niebauer J, Hauer K, Neumann J, et al. Regular physical exercise and low-fat diet. Effects on progression of coronary artery disease. Circulation 1992;86(1):1-11.

\section{Seki 2003 \{published data only\}}

Seki E, Watanabe Y, Sunayama S, Iwama Y, Shimada K, Kawakami K, et al. Effects of phase III cardiac rehabilitation programs on health-related quality of life in elderly patients with coronary artery disease: Juntendo Cardiac Rehabilitation Program (J-CARP). Circulation Journal 2003;67(1):73-7.
Seki 2008 \{published data only\}

Seki E, Watanabe Y, Shimada K, Sunayama S, Onishi T, Kawakami K, et al. Effects of a phase III cardiac rehabilitation program on physical status and lipid profiles in elderly patients with coronary artery disease: Juntendo Cardiac Rehabilitation Program (J-CARP). Circulation Journal 2008;72(8):1230-4.

\section{Shaw 1981 \{published data only\}}

Naughton J. The National Exercise and Heart Disease Project. The pre-randomization exercise program. Report number 2 . Cardiology 1978;63(6):352-67.

* Shaw LW. Effects of a prescribed supervised exercise program on mortality and cardiovascular morbidity in patients after a myocardial infarction. The National Exercise and Heart Disease Project. American Journal of Cardiology 1981;48(1):39-46.

Stern MJ, Cleary P. The National Exercise and Heart Disease Project: Long-term psychosocial outcome. Archives of Internal Medicine 1982;142(6):1093-7.

\section{Sivarajan 1982 \{published data only\}}

Ott CR, Sivarajan ES, Newton KM, Almes MJ, Bruce RA, Bergner $\mathrm{M}$, et al. A controlled randomized study of early cardiac rehabilitation: The sickness impact profile as an assessment tool. Heart \& Lung 1983;12(2):162-70.

Sivarajan ES, Bruce RA, Almes MJ, Green B, Belanger L, Lindskog BD, et al. In-hospital exercise after myocardial infarction does not improve treadmill performance. New England Journal of Medicine 1981;305(7):357-62.

* Sivarajan ES, Bruce RA, Lindskog BD, Almes MJ, Belanger L, Green B. Treadmill test responses to an early exercise program after myocardial infarction: A randomized study. Circulation 1982;65(7):1420-8

Sivarajan ES, Newton KM, Almes MJ, Kempf TM, Mansfield LW, Bruce RA. Limited effects of outpatient teaching and counselling after myocardial infarction: A controlled study. Heart \& Lung 1983;12(1):65-73.

\section{Specchia 1996 \{published data only\}}

Specchia G, De Servi S, Scirè A, Assandri J, Berzuini C, Angoli L, et al. Interaction between exercise training and ejection fraction in predicting prognosis after a first myocardial infarction. Circulation 1996;94(5):978-82.

\section{Ståhle 1999 \{published data only\}}

Hage C, Mattsson E, Ståhle A. Long term effects of exercise training on physical activity level and quality of life in elderly coronary patients - a three- to six-year follow-up. Physiotherapy Research International 2003;8(1):13-22.

Ståhle A, Lindquist I, Mattsson E. Important factors for physical activity among elderly patients one year after an acute myocardial infarction. Scandinavian Journal of Rehabilitation Medicine 2000;32(3):111-6.

* Ståhle A, Mattsson E, Rydén L, Unden AL, Nordlander R. Improved physical fitness and quality of life following training of elderly patients after acute coronary events. A 1 year follow- 
up randomized controlled study. European Heart Journal 1999;20(20):1475-84.

Ståhle A, Nordlander R, Rydén L, Mattsson E. Effects of organized aerobic group training in elderly patients discharged after an acute coronary syndrome. A randomized controlled study.. Scandinavian Journal of Rehabilitation Medicine 1999;31(2):101-7.

Ståhle A, Tollbäck A. Effects of aerobic group training on exercise capacity, muscular endurance and recovery in elderly patients with recent coronary events: A randomized, controlled study. Advances in Physiotherapy 2001;3:29-37.

\section{Stern 1983 \{published data only\}}

Stern MJ, Gorman PA, Kaslow L. The group counseling v exercise therapy study. A controlled intervention with subjects following myocardial infarction. Archives of Internal Medicine 1983;143(9):1719-25.

\section{Toobert 2000 \{published data only\}}

Toobert DJ, Glasgow RE, Nettekoven LA, Brown JE. Behavioral and psychosocial effects of intensive lifestyle management for women with coronary heart disease. Patient Education and Counseling 1998;35(3):177-88.

* Toobert DJ, Glasgow RE, Radcliffe JL. Physiologic and related behavioral outcomes from the Women's Lifestyle Heart Trial. Annals of Behavioral Medicine 2000;22(1):1-9.

\section{Vecchio 1981 \{published data only\}}

Vecchio C, Cobelli F, Opasich C, Assandri J, Poggi G, Griffo R. Early functional evaluation and physical rehabilitation in patients with wide myocardial infarction [Valutazione funzionale precoce e riabilitazione fisica nei pazienti con infarto miocardico esteso]. Giornale Italiano di Cardiologia 1981;11:419-29.

\section{Vermeulen 1983 \{published data only\}}

Vermeulen A, Lie KI, Durrer D. Effects of cardiac rehabilitation after myocardial infarction: changes in coronary risk factors and long-term prognosis. American Heart Journal 1983;105(5):798-801.

\section{VHSG 2003 \{published data only\}}

Vestfold Heartcare Study Group. Influence on lifestyle measures and five-year coronary risk by a comprehensive lifestyle intervention programme in patients with coronary heart disease. European Journal of Cardiovascular Prevention and Rehabilitation 2003;10(6):429-37.

Wang 2012 \{published data only\}

Wang W, Chair SY, Thompson DR, Twinn SF. Effects of homebased rehabilitation on health-related quality of life and psychological status in Chinese patients recovering from acute myocardial infarction. Heart \& Lung 2012;41:15-25.

\section{West 2012 \{published data only\}}

West RR, Jones DA, Henderson AH. Rehabilitation after myocardial infarction trial (RAMIT): multi-centre randomised controlled trial of comprehensive cardiac rehabilitation in patients following acute myocardial infarction. Heart 2012;98:637-44.

WHO 1983 \{published data only\}

World Health Organization. Rehabilitation and comprehensive secondary prevention after acute myocardial infarction. EURO Reports and Studies 841983.

\section{Wilhelmsen 1975 \{published data only\}}

Sanne H. Exercise tolerance and physical training of nonselected patients after myocardial infarction. Acta Medica Scandinavica 1973;Supplementum 551:1-124.

* Wilhelmsen L, Sanne H, Elmfeldt D, Grimby G, Tibblin G, Wedel $\mathrm{H}$. A controlled trial of physical training after myocardial infarction. Effects on risk factors, nonfatal reinfarction, and death. Preventive Medicine 1975;4(4):491-508.

Yu 2003 \{published data only\}

Yu CM, Li LS, Ho HH, Lau CP. Long-term changes in exercise capacity, quality of life, body anthropometry, and lipid profiles after a cardiac rehabilitation program in obese patients with coronary heart disease. American Journal of Cardiology 2003;91(3):321-5.

\section{Yu 2004 \{published data only\}}

Yu C, Li L, Lam M, Siu D, Miu R, Lau C. Effect of a cardiac rehabilitation program on left ventricular diastolic function and its relationship to exercise capacity in patients with coronary heart disease: experience from a randomized, controlled study. American Heart Journal 2004;147(5):e24.

* Yu CM, Lau CP, Chau J, McGhee S, Kong SL, Cheung BM, et al. A short course of cardiac rehabilitation program is highly cost effective in improving long-term quality of life in patients with recent myocardial infarction or percutaneous coronary intervention. Archives of Physical Medicine and Rehabilitation 2004;85(12):1915-22.

\section{Zwisler 2008 \{published and unpublished data\}}

Kruse M, Hochstrasser S, Zwisler AD, Kjellberg J. Comprehensive cardiac rehabilitation: A cost assessment based on a randomized clinical trial. International Journal of Technology Assessment in Health Care 2006;22(4):478-83.

* Zwisler AD, Soja AM, Rasmussen S, Frederiksen M, Abedini S, Appel J, et al. Hospital-based comprehensive cardiac rehabilitation versus usual care among patients with congestive heart failure, ischemic heart disease, or high risk of ischemic heart disease: 12-month results of a randomized clinical trial. American Heart Journal 2008;155(6):1106-13.

\section{References to studies excluded from this review}

\section{Agren 1989 \{published data only\}}

Agren B, Olin C, Castenfors J, Nilsson-Ehle P. Improvements of the lipoprotein profile after coronary bypass surgery: additional effects of an exercise training program. European Heart Journal 1989;10(5):451-8. 
Andersson 2010 \{published data only\}

Andersson A, Sundel K L, Unden A L, Schenck-Gustafsson K, Eriksson I. A five-year rehabilitation programme for younger women after a coronary event reduces the need for hospital care. Scandinavian Journal of Public Health 2010;38:566-73.

\section{Aronov 2006 \{published data only\}}

Aronov DM, Krasnitski VB, Bubnova MG, Posdniakov luM, Ioseliani DV, Shchegol'kov AN, et al. Exercise in outpatient complex rehabilitation and secondary prophylaxis in patients with ischemic heart disease after acute coronary events (a cooperative trial in Russia). Terapevticheskii Arkhiv 2006;78(9):33-8.

\section{Asbury 2012 \{published data only\}}

Asbury EA, Webb CM, Probert H, Wright C, Barbir M, Fox K, et al. Cardiac rehabilitation to improve physical functioning in refractory angina: a pilot study. Cardiology 2012;122:170-7.

\section{Astengo 2010 \{published data only\}}

Astengo M, Dahl A, Karlsson T, Mattsson-Hulten L, Wiklund O, Wennerblom B. Physical training after percutaneous coronary intervention in patients with stable angina: effects on working capacity, metabolism, and markers of inflammation. European Journal of Cardiovascular Prevention \& Rehabilitation 2010;17:349-54.

\section{Ballantyne 1982 \{published data only\}}

Ballantyne FC, Clark RS, Simpson HS, Ballantyne D. The effect of moderate physical exercise on the plasma lipoprotein subfractions of male survivors of myocardial infarction. Circulation 1982;65(5):913-8.

\section{Bär 1992 \{published data only\}}

Bär FW, Hoppener P, Diederiks J, Vonken H, Bekkers J, Hoofd W, Appels A, et al. Cardiac rehabilitation contributes to the restoration of leisure and social activities. Journal of Cardiopulmonary Rehabilitation 1992;12(2):117-25.

\section{Belardinelli 2007 \{published data only\}}

Belardinelli R, Lacalaprice F, Piccoli G, lacobone G, Piva R. Long-term benefits of cardiac rehabilitation in patients with incomplete revascularization: 5-year follow-up. Circulation 2007;116(16):3543.

\section{Bilinska 2010 \{published data only\}}

Bilinska M, Kosydar-Piechna M, Gasiorowska A, Mikulski T, Piotrowski W, Nazar K, et al. Influence of dynamic training on hemodynamic, neurohormonal responses to static exercise and on inflammatory markers in patients after coronary artery bypass grafting. Circulation Journal 2010;74:2598-604.

\section{Bilinska 2013 \{published data only\}}

Bilinska M, Kosydar-Piechna M, Mikulski T, Piotrowicz E, Gasiorowska A, Piotrowski W, et al. Influence of aerobic training on neurohormonal and hemodynamic responses to head-up tilt test and on autonomic nervous activity at rest and after exercise in patients after bypass surgery. Cardiology Journal 2013;20:17-24.

\section{Björntorp 1972 \{published data only\}}

Björntorp, Berchtold P, Grimby G, Lindholm B, Sanne H, Tibblin $\mathrm{G}$, et al. Effects of physical training on glucose tolerance, plasma insulin and lipids and on body composition in men after myocardial infarction. Acta Medica Scandinavica 1972;192(1-6):439-43.

\section{Blumenthal 1997 \{published data only\}}

Blumenthal JA, Wei J, Babyak MA, Krantz DS, Frid DJ, Coleman RE, et al. Stress management and exercise training in cardiac patients with myocardial ischemia: effects on prognosis and evaluation of mechanisms. Archives of Internal Medicine 1997;157(19):2213-23.

\section{Bourke 2010 \{published data only\}}

Bourke L, Tew GA, Milo M, Crossman DC, Saxton JM, Chico TJ. Study protocol: a randomised controlled trial investigating the effect of exercise training on peripheral blood gene expression in patients with stable angina. BMC Public Health 2010;10:620.

\section{Bubnova 2014 \{published data only\}}

Bubnova MG, Aronov DM, Krasnitskii VB, Ioseliani DG, Novikova NK, Rodzinskaia EM. Программа обучения дома упражнения после острого коронарного синдрома и / или эндоваскулярнойкоронарной интервенции: эффективность и проблемы мотивации пациента. [A home exercise training program after acute coronary syndrome and/ or endovascular coronary intervention: efficiency and a patient motivation problem]. Terapevticheskii Arkhiv 2014;86:23-32.

\section{Busch 2012 \{published data only\}}

Busch JC, Lillou D, Wittig G, Bartsch P, Willemsen D, Oldridge $\mathrm{N}$, et al. Resistance and balance training improves functional capacity in very old participants attending cardiac rehabilitation after coronary bypass surgery.. Journal of the American Geriatrics Society 2012;60:2270-6. Erratum in: Journal of the American Geriatrics Society 2013;61:3:479.

\section{Butler 2009 \{published data only\}}

Butler L, Furber S, Phongsavan P, Mark A, Bauman A. Effects of a Pedometer-Based Intervention on Physical Activity Levels After Cardiac Rehabilitation: a randomized controlled trial. Journal of Cardiopulmonary Rehabilitation and Prevention 2009;29:105-14.

\section{Carlsson 1997 \{published data only\}}

Carlsson R, Lindberg G, Westin L, Israelsson B. Influence of coronary nursing management follow up on lifestyle after acute myocardial infarction. Heart 1997;77(3):256-9.

\section{Chang 2010 \{published data only\}}

Chang R, Koo M, Kan C, Yu Z, Chu I, Hsu C, et al. Effects of Tai Chi rehabilitation on heart rate responses in patients with coronary artery disease. American Journal of Chinese Medicine 2010;38:461-72.

\section{Chatian 2014 \{published data only\}}

Chatian M, Tarchalski J L, Lisowski J, Poziomska-Piatkowska E. Wpływ rehabilitacji ambulatoryjnej kardiologicznej na sprawności fizycznej na pacjentów po STEMI [The influence of the outpatient cardiologic rehabilitation on the physical 
fitness at patients after a STEMI]. Polski Merkuriusz Lekarski 2014;36:88-91.

\section{Chow 2012 \{published data only\}}

Chow CK, Redfern J, Thiagalingam A, Jan S, Whittaker R, Hackett $M$, et al. Design and rationale of the tobacco, exercise and diet messages (TEXT ME) trial of a text message-based intervention for ongoing prevention of cardiovascular disease in people with coronary disease: a randomised controlled trial protocol. BMJ Open 2012;2:e000606.

\section{Edstrom-Pluss 2009 \{published data only\}}

Edstrom-Pluss C, Billing E, Held C, Henriksson P, Kiessling A, Karlsson MR, et al. Long-term beneficial effects of an expanded cardiac rehabilitation after an acute myocardial infarction or coronary artery by-pass grafting: a five year follow-up of a randomized controlled study. Eur. Heart J. 2009;30:75-6.

\section{Espinosa 2004 \{published data only\}}

Espinosa Caliani S, Bravo Navas JC, Gomez-Doblas JJ, Collantes Rivera R, Gonzalez Jimenez B, Martinez Lao M, et al. Postmyocardial infarction cardiac rehabilitation in low risk patients. Results with a coordinated program of cardiological and primary care. Revista Espanola de Cardiologia 2004;57:53-9.

\section{Gao 2007 \{published data only\}}

Gao WG, Hu DY, Ma WL, Tang CZ, Li J, Hasimu B, et al. Effect of health management on the rehabilitation of patients undergoing coronary artery bypass graft. Journal of Clinical Rehabilitative Tissue Engineering Research 2007;11(25):4874-8.

\section{Ghashghaei 2012 \{published data only\}}

Ghashghaei FE, Sadeghi M, Marandi SM, Ghashghaei SE. Exercise-based cardiac rehabilitation improves hemodynamic responses after coronary artery bypass graft surgery. Arya Atherosclerosis 2012;7:151-6.

\section{Giallauria 2009 \{published data only\}}

Giallauria F, Galizia G, Lucci R, D'Agostino M, Vitelli A, Maresca L, et al. Favourable effects of exercise-based Cardiac Rehabilitation after acute myocardial infarction on left atrial remodeling. International Journal of Cardiology 2009;136:300-6.

\section{Giallauria 2012 \{published data only\}}

Giallauria F, Acampa W, Ricci F, Vitelli A, Maresca L, Mancini M, et al. Effects of exercise training started within 2 weeks after acute myocardial infarction on myocardial perfusion and left ventricular function: a gated SPECT imaging study. European Journal of Preventive Cardiology 2012;19:1410-9.

\section{Giallauria 2013 \{published data only\}}

Giallauria F, Acampa W, Ricci F, Vitelli A, Torella G, Lucci R, et al. Exercise training early after acute myocardial infarction reduces stress-induced hypoperfusion and improves left ventricular function. European Journal of Nuclear Medicine \& Molecular Imaging 2013;40:315-24.

\section{Giannuzzi 2008 \{published data only\}}

Giannuzzi P, Temporelli PL, Marchioli R, Maggioni AP, Balestroni G, Ceci V, et al. Global secondary prevention strategies to limit event recurrence after myocardial infarction:
Results of the GOSPEL study, a multicenter, randomized controlled trial from the Italian Cardiac Rehabilitation Network. Archives of Internal Medicine 2008;168(20):2194-204.

Gielen 2003 \{published data only\}

Gielen S, Erbs S, Linke A, Mobius-Winkler S, Schuler G, Hambrecht R. Home-based versus hospital-based exercise programs in patients with coronary artery disease: effects on coronary vasomotion. American Heart Journal 2003;145(1):e3.

\section{Ha 2011 \{published data only\}}

Ha Yi-Kyung, Jung Yoen-Yi. Development and application of an early exercise program for open heart surgery patients [Korean]. Journal of Korean Critical Care Nursing 2011;4:1p.

Haddadzadeh 2011 \{published data only\}

Haddadzadeh MH, Maiya AG, Padmakumar R, Shad B, Mirbolouk F. Effect of exercise-based cardiac rehabilitation on ejection fraction in coronary artery disease patients: a randomized controlled trial. Heart Views 2011;12:51-7.

\section{Hansen 2009 \{published data only\}}

Hansen D, Dendale P, Leenders M, Berger J, Raskin A, Vaes J, et al. Reduction of cardiovascular event rate: different effects of cardiac rehabilitation in CABG and $\mathrm{PCI}$ patients. Acta Cardiologica 2009;64:639-44.

\section{Hansen 2010 \{published data only\}}

Hansen D, Dendale P, Raskin A, Schoonis A, Berger J, Vlassak I, et al. Long-term effect of rehabilitation in coronary artery disease patients: randomized clinical trial of the impact of exercise volume. Clinical Rehabilitation 2010;24:319-27.

\section{Hanssen 2009 \{published data only\}}

Hanssen TA, Nordrehaug JE, Eide GE, Hanestad BR. Does a telephone follow-up intervention for patients discharged with acute myocardial infarction have long-term effects on healthrelated quality of life? A randomised controlled trial. Journal of Clinical Nursing 2009;18:1334-45.

\section{Hawkes 2009 \{published data only\}}

Hawkes AL, Atherton J, Taylor CB, Scuffham P, Eadie K, Miller $\mathrm{NH}$, et al. Randomised controlled trial of a secondary prevention program for myocardial infarction patients ('ProActive Heart'): study protocol. Secondary prevention program for myocardial infarction patients. BMC Cardiovascular Disorders 2009; Vol. 9, issue 1:16.

\section{Heldal 2000 \{published data only\}}

Heldal M, Sire S, Dale J. Randomised training after myocardial infarction: Short and long-term effects of exercise training after myocardial infarction in patients on beta-blocker treatment. A randomized, controlled study. Scandinavian Cardiovascular Journal 2000;34(1):59-64.

\section{Houle 2011 \{published data only\}}

Houle J, Doyon O, Vadeboncoeur N, Turbide G, Diaz A, Poirier P. Innovative program to increase physical activity following an acute coronary syndrome: randomized controlled trial. Patient Education \& Counseling 2011;85:e237-44. 
Huerre 2010 \{published data only\}

Huerre C, Guiot A, Marechaux S, Auffray JL, Bauchart JJ, Montaigne $\mathrm{D}$, et al. Functional decline in elderly patients presenting with acute coronary syndromes: impact on midterm outcome. Archives of cardiovascular diseases 2010;103:19-25.

\section{Jiang 2007 \{published data only\}}

Jiang X, Sit JW, Wong TKS. A nurse-led cardiac rehabilitation programme improves health behaviours and cardiac physiological risk parameters: evidence from Chengdu, China. Journal of Clinical Nursing 2007;16(10):1886-97.

Karpova 2009 \{published data only\}

Karpova ES, Kotel'nikova EV, Lipchanskaia TP, Poliakova NV, Liamina NP. Rehabilitative and prophylactic measures including physical training for the correction of risk factors in patients presenting with ischemic heart disease following percutaneous coronary interventions. Voprosy Kurortologii, Fizioterapii i Lechebnoi Fizicheskoi Kultury 2009;6:6-9.

Kavanagh 1973 \{published data only\}

Kavanagh T, Shephard RJ, Doney H, Pandit V. Exercise versus hypnotherapy in coronary rehabilitation. Canadian Family Physician 1973;19:62-6.

\section{Kentala 1972 \{published data only\}}

Kentala E. Physical fitness and feasibility of physical rehabilitation after myocardial infarction in men of working age. Annals of Clinical Research 1972;4(Suppl 9):1-84.

Kim 2011 \{published data only\}

Kim C, Kim DY, Moon CJ. Prognostic influences of cardiac rehabilitation in Korean acute myocardial infarction patients. Annals of Rehabilitation Medicine 2011;35:375-80.

Kim 2012 \{published data only\}

Kim C, Choi HE, Kim BO, Lim MH. Impact of Exercise-based Cardiac Rehabilitation on In-stent Restenosis with Different Generations of Drug Eluting Stent. Annals of Rehabilitation Medicine 2012;36:254-61.

\section{Kim 2013 \{published data only\}}

Kim HJ, Oh JK, Kim C, Jee H, Shin KA, Kim YJ. Effects of sixweek cardiac rehabilitation and exercise on adiponectin in patients with acute coronary syndrome. Kardiologia Polska 2013;71:924-30.

\section{Krachler 1997 \{published data only\}}

Krachler M, Lindschinger M, Eber B, Watzinger N, Wallner S. Trace elements in coronary heart disease. Biological Trace Element Research 1997;60(3):175-85.

\section{Kubilius 2012 \{published data only\}}

Kubilius R, Jasiukeviciene L, Grizas V, Kubiliene L, Jakubseviciene E, Vasiliauskas D. The impact of complex cardiac rehabilitation on manifestation of risk factors in patients with coronary heart disease. Medicina (Kaunas, Lithuania) 2012;48:166-73.

\section{Lee 2013 \{published data only\}}

Lee HY, Kim JH, Kim BO, Byun YS, Cho S, Goh CW, et al. Regular exercise training reduces coronary restenosis after percutaneous coronary intervention in patients with acute myocardial infarction. International Journal of Cardiology 2013;167:2617-22.

\section{Li 2004 \{published data only\}}

Li H, Guo L, Sun JZ, Feng JZ, Wang P, Wu GL, et al. Effect of exercise therapy on the quality of life in patients after successful percutaneous transluminal coronary angioplasty. Chinese Journal of Clinical Rehabilitation 2004;8(9):1601-3.

\section{Liao 2003 \{published data only\}}

Liao X, Ma H, Dong Y. Effects of early rehabilitation programme on heart rate variability and quality of life in patients with uncomplicated acute myocardial infarction. Journal of Rehabilitation Medicine 2003;18(3):153-5.

\section{Lie 2009 \{published data only\}}

Lie I, Arnesen H, Sandvik L, Hamilton G, Bunch EH. Healthrelated quality of life after coronary artery bypass grafting. The impact of a randomised controlled home-based intervention program. Quality of Life Research 2009; Vol. 18, issue 2:201-7.

\section{Mameletzi 2011 \{published data only\}}

Mameletzi D, Kouidi E, Koutlianos N, Deligiannis A. Effects of long-term exercise training on cardiac baroreflex sensitivity in patients with coronary artery disease: a randomized controlled trial. Clinical Rehabilitation 2011;25:217-27.

\section{Mandic 2013 \{published data only\}}

Mandic S, Hodge C, Stevens E, Walker R, Nye ER, Body D, et al. Effects of Community-Based Cardiac Rehabilitation on Body Composition and Physical Function in Individuals with Stable Coronary Artery Disease: 1.6-Year Follow-up. Biomed Research International 2013;2013:7.

\section{Martinez 2011 \{published data only\}}

Martinez DG, Nicolau JC, Lage RL, Toschi-Dias E, de Matos LD, Alves MJ, et al. Effects of long-term exercise training on autonomic control in myocardial infarction patients. Hypertension 2011;58:1049-56.

\section{Mayer-Berger 2014 \{published data only\}}

Mayer-Berger W, Simic D, Mahmoodzad J, Burtscher R, Kohlmeyer M, Schwitalla B, et al. Efficacy of a long-term secondary prevention programme following inpatient cardiovascular rehabilitation on risk and health-related quality of life in a low-education cohort: A randomized controlled study. European Journal of Preventive Cardiology 2014;21:145-52.

\section{Mezey 2008 \{published data only\}}

Mezey B, Kullmann L, Smith K, Sarolta B, Sandori K, Belicza E, et al. Outpatient cardiac rehabilitation: initial experience in the first Hungarian multicenter study. Orvosi Hetilap 2008;149(8):353-9. 


\section{Mohammed 2012 \{published data only\}}

Mehani SHM. Autonomic adaptation and functional capacity outcomes after hospital-based cardiac rehabilitation post coronary artery by pass graft. Indian Journal of Physiotherapy and Occupational Therapy 2012; Vol. 6, issue 3:263.

\section{Moholdt 2012a \{published data only\}}

Moholdt T, Aamot IL, Granoien I, Gjerde L, Myklebust G, Walderhaug $\mathrm{L}$, et al. Aerobic interval training increases peak oxygen uptake more than usual care exercise training in myocardial infarction patients: a randomized controlled study. Clinical Rehabilitation 2012;26:33-44.

\section{Moholdt 2012b \{published data only\}}

Moholdt T, Bekken Vold M, Grimsmo J, Slordahl SA, Wisloff U. Home-based aerobic interval training improves peak oxygen uptake equal to residential cardiac rehabilitation: a randomized, controlled trial. PLOS ONE [Electronic Resource] 2012; 7:e41199.

\section{Molino-Lova 2013 \{published data only\}}

Molino-Lova R, Pasquini G, Vannetti F, Paperini A, Forconi T, Polcaro $P$, et al. Effects of a structured physical activity intervention on measures of physical performance in frail elderly patients after cardiac rehabilitation: a pilot study with 1year follow-up. Internal and Emergency Medicine 2013;8:581-9.

\section{Murphy 2012 \{published data only\}}

Murphy SM, Edwards RT, Williams N, Raisanen L, Moore G, Linck $P$, et al. An evaluation of the effectiveness and cost effectiveness of the National Exercise Referral Scheme in Wales, UK: a randomised controlled trial of a public health policy initiative.. Journal of Epidemiology \& Community Health 2012;66:745-53 Erratum in: Journal of Epidemiology \& Community Health 2012;66:11:1082.

\section{Pater $\mathbf{2 0 0 0}$ \{published data only\}}

Pater C, Jacobsen C, Rollag A, Sandvik L, Erikssen J, Kogstad E. Design of a randomized controlled trial of comprehensive rehabilitation in patients with myocardial infarction, stabilized acute coronary syndrome, percutaneous transluminal coronary angioplasty or coronary artery bypass grafting: Akershus Comprehensive Cardiac Rehabilitation Trial (the CORE Study). Current Controlled Trials in Cardiovascular Medicine 2000;1(3):177-83.

\section{Pedersen 2013 \{published data only\}}

Pedersen LR, Olsen RH, Frederiksen M, Astrup A, Chabanova E, Hasbak P, et al. Copenhagen study of overweight patients with coronary artery disease undergoing low energy diet or interval training: the randomized CUT-IT trial protocol. BMC Cardiovascular Disorders 2013;13:106.

\section{Peschel 2007 \{published data only\}}

Peschel T, Sixt S, Beitz F, Sonnabend M, Muth G, Thiele H, et al. High, but not moderate frequency and duration of exercise training induces downregulation of the expression of inflammatory and atherogenic adhesion molecules. European Journal of Cardiovascular Prevention and Rehabilitation 2007;14(3):476-82.

\section{Piestrzeniewicz 2004 \{published data only\}}

Piestrzeniewicz K, Navarro-Kuczborska N, Bolinska H, Jegier A, Maciejewski M. The impact of comprehensive cardiac rehabilitation in young patients after acute myocardial infarction treated with primary coronary intervention on the clinical outcome and leading again a "normal" life [Korzystne efekty kompleksowej rehabilitacji kardiologicznej u osob do 55 roku zycia, po zawale miesnia sercowego, leczonych za pomoca pierwotnej angioplastyki]. Polskie Archiwum Medycyny Wewnetrznej 2004;111(3):309-17.

\section{Pluss 2011 \{published data only\}}

Pluss CE, Billing E, Held C, Henriksson P, Kiessling A, Karlsson MR, et al. Long-term effects of an expanded cardiac rehabilitation programme after myocardial infarction or coronary artery bypass surgery: a five-year follow-up of a randomized controlled study. Clinical Rehabilitation 2011;25:79-87.

\section{Poortaghi 2011 \{published data only\}}

Poortaghi S, Atri SB, Safayian A, Baghernia A. General health improves with home-based cardiac rehabilitation program. Saudi Medical Journal 2011;32:407-11.

\section{Poortaghi 2013 \{published data only\}}

Poortaghi S, Baghernia A, Golzari SE, Safayian A, Atri SB. The effect of home-based cardiac rehabilitation program on self efficacy of patients referred to cardiac rehabilitation center. BMC Research Notes 2013;6:287.

\section{Ribeiro 2012 \{published data only\}}

Ribeiro F, Alves AJ, Teixeira M, Miranda F, Azevedo C, Duarte JA, et al. Exercise training enhances autonomic function after acute myocardial infarction: a randomized controlled study. Revista Portuguesa de Cardiologia 2012;31:135-41.

\section{Rideout 2012 \{published data only\}}

Rideout A, Lindsay G, Godwin J. Patient mortality in the 12 years following enrolment into a pre-surgical cardiac rehabilitation programme. Clinical Rehabilitation 2012;26:642-7.

\section{Roviaro 1984 \{published data only\}}

Roviaro S, Holmes DS, Holmsten RD. Influence of a cardiac rehabilitation program on the cardiovascular, psychological, and social functioning of cardiac patients. Journal of Behavioral Medicine 1984;7(1):61-81.

\section{Sadeghi 2013 \{published data only\}}

Sadeghi M, Garakyaraghi M, Khosravi M, Taghavi M, Sarrafzadegan N, Roohafza H. The impacts of cardiac rehabilitation program on echocardiographic parameters in coronary artery disease patients with left ventricular dysfunction. Cardiology Research and Practice 2013; Vol. 2013.

\section{Sagar 2012 \{published data only\}}

Sagar N, Bangi NA, Moiz JA. Effect of supervised versus home based phase II cardiac rehabilitation program on exercise capacity and quality of life in post CABG patients. Indian Journal of Physiotherapy and Occupational Therapy - An International Journal 2012; Vol. 6:59-64. 
Sato 2010 \{published data only\}

Sato S, Makita S, Uchida R, Ishihara S, Masuda M. Effect of Tai Chi training on baroreflex sensitivity and heart rate variability in patients with coronary heart disease. International Heart Journal 2010;51:238-41.

\section{Sawatzky 2014 \{published data only\}}

Sawatzky JA, Kehler DS, Ready AE, Lerner N, Boreskie S, Lamont $\mathrm{D}$, et al. Prehabilitation program for elective coronary artery bypass graft surgery patients: a pilot randomized controlled study. Clinical Rehabilitation 2014; Vol. 28:648-57.

\section{Schumacher 2006 \{published data only\}}

Schumacher A, Peersen K, Sommervoll L, Seljeflot I, Arnesen H, Otterstad JE. Physical performance is associated with markers of vascular inflammation in patients with coronary heart disease. European Journal of Cardiovascular Prevention and Rehabilitation 2006;13(3):356-62.

\section{Schwaab 2011 \{published data only\}}

Schwaab B, Waldmann A, Katalinic A, Sheikhzadeh A, Raspe H. In-patient cardiac rehabilitation versus medical care - a prospective multicentre controlled 12 months follow-up in patients with coronary heart disease. European Journal of Cardiovascular Prevention \& Rehabilitation 2011;18:581-6.

\section{Shabani 2010 \{published data only\}}

Shabani R, Gaeini AA, Nikoo MR, Nikbackt H, Sadegifar M. Effect of cardiac rehabilitation program on exercise capacity in women undergoing coronary artery bypass graft in HamadanIran. International Journal of Preventive Medicine 2010;1:247-51.

\section{Shikhova 2010 \{published data only\}}

Shikhova EV, Guliaeva SF, Tsarev lu K, Chervotkina LA. Clinical and cost effectiveness of rehabilitation programs including physical exercises for patients with ischemic heart disease under conditions of resort and outpatient clinics. Voprosy Kurortologii, Fizioterapii i Lechebnoi Fizicheskoi Kultury 2010;6:9-12.

\section{Siqueira-Catania 2013 \{published data only\}}

Siqueira-Catania A, Cezaretto A, de Barros CR, Salvador EP, Dos Santos TC, Ferreira SR. Cardiometabolic risk reduction through lifestyle intervention programs in the Brazilian public health system. Diabetology \& metabolic syndrome 2013;5:21.

\section{Soleimannejad 2014 \{published data only\}}

Soleimannejad K, Nouzari Y, Ahsani A, Nejatian M, Sayehmiri K. Evaluation of the effect of cardiac rehabilitation on left ventricular diastolic and systolic function and cardiac chamber size in patients undergoing percutaneous coronary intervention. Journal of Tehran University Heart Center 2014;9:54-8.

\section{Stahle 1999 \{published data only\}}

Stahle A, Nordlander R, Ryden L, Mattsson E. Effects of organized aerobic group training in elderly patients discharged after an acute coronary syndrome. A randomized controlled study. Scandinavian Journal of Rehabilitation Medicine 1999;31:101-7.
Stenlund 2005 \{published data only\}

Stenlund T, Lindström B, Granlund M, Burell G. Cardiac rehabilitation for the elderly: Qi Gong and group discussions. European Journal of Cardiovascular Prevention and Rehabilitation 2005;12(1):5-11.

Takeyama 2000 \{published data only\}

Takeyama J, Itoh H, Kato M, Koike A, Aoki K, Fu LT, et al. Effects of physical training on the recovery of the autonomic nervous activity during exercise after coronary artery bypass grafting: effects of physical training after CABG. Japanese Circulation Journal 2000;64(11):809-13.

Tokmakidis 2003 \{published data only\}

* Tokmakidis SP, Volaklis KA. Training and detaining effects of a combined-strength and aerobic exercise program on blood lipids in patients with coronary artery disease. Journal of Cardiopulmonary Rehabilitation 2003;23(3):193-200.

Volaklis KA, Douda HT, Kokkinos PF, Tokmakidis SP. Physiological alterations to detraining following prolonged combined strength and aerobic training in cardiac patients. European Journal of Cardiovascular Prevention and Rehabilitation 2006;13(3):375-80.

\section{Turkstra 2013 \{published data only\}}

Turkstra E, Hawkes AL, Oldenburg B, Scuffham PA. Costeffectiveness of a coronary heart disease secondary prevention program in patients with myocardial infarction: Results from a randomised controlled trial (ProActive Heart). BMC Cardiovascular Disorders 2013;13(1):33.

Uhlemann 2012 \{published data only\}

Uhlemann M, Adams V, Lenk K, Linke A, Erbs S, Adam J, et al. Impact of different exercise training modalities on the coronary collateral circulation and plaque composition in patients with significant coronary artery disease (EXCITE trial): study protocol for a randomized controlled trial. Trials [Electronic Resource] 2012;13:167.

\section{Walters 2010 \{published data only\}}

Walters D L, Sarela A, Fairfull A, Neighbour K, Cowen C, Stephens B, et al. A mobile phone-based care model for outpatient cardiac rehabilitation: the care assessment platform (CAP). Bmc Cardiovascular Disorders 2010;10:8

\section{Wood 2008 \{published data only\}}

Wood DA, Kotseva K, Connolly S, Jennings C, Mead A, Jones J, et al. Nurse-coordinated multidisciplinary, family-based cardiovascular disease prevention programme (EUROACTION) for patients with coronary heart disease and asymptomatic individuals at high risk of cardiovascular disease: a paired, cluster-randomised controlled trial. The Lancet 2008; Vol. 371:1999-2012.

\section{Wosornu 1996 \{published data only\}}

Wosornu D, Bedford D, Ballantyne D. A comparison of the effects of strength and aerobic exercise training on exercise capacity and lipids after coronary artery bypass surgery. European Heart Journal 1996;17(6):854-63. 
Yonezawa 2009 \{published data only\}

Yonezawa R, Masuda T, Matsunaga A, Takahashi Y, Saitoh M, Ishii A, et al. Effects of phase II cardiac rehabilitation on job stress and health-related quality of life after return to work in middle-aged patients with acute myocardial infarction. International Heart Journal 2009; Vol. 50, issue 3:279-90.

\section{Zheng 2008 \{published data only\}}

Zheng H, Luo M, Shen Y, Ma Y, Kang W. Effects of 6 months exercise training on ventricular remodelling and autonomic tone in patients with acute myocardial infarction and percutaneous coronary intervention. Journal of Rehabilitation Medicine 2008;40(9):776-9.

Zhu 2013 \{published data only\}

Zhu LX, Ho SC, Sit JWH. The effect of a TTM-based exercise stage-matched intervention on angina in patients with coronary heart disease: A randomized controlled trial. International Journal of Cardiology 2013;1):S6.

\section{References to studies awaiting assessment}

Devi 2014 \{published data only\}

Devi R, Powell J, Singh S. A Web-Based Program Improves Physical Activity Outcomes ina Primary Care Angina Population: Randomized Controlled Trial. J Med Internet Res 2014;16(9):e186.

\section{Ghroubi 2012 \{published data only\}}

Ghroubi S, Elleuch W, Abid L, Kammoun S, Elleuch MH. The effects of cardiovascular rehabilitation after coronary stenting [Apport de la readaptation cardiovasculaire dans les suites d'une angioplastie transluminale]. Annals of Physical and Rehabilitation Medicine 2012;55:e307+e309.

\section{Son 2008 \{published data only\}}

Son YJ. The development and effects of an integrated symptom management program for prevention of recurrent cardiac events after percutaneous coronary intervention. Journal of Korean Academy of Nursing 2008;38(2):217-28.

\section{Von Roeder 2011 \{published data only\}}

Von Roeder MDW, Adams V, Walther C, Erbs S, Linke A, Hambrecht $\mathrm{R}$, et al. Exercise training vs. $\mathrm{PCl} /$ stenting in stable coronary artery disease: Long term effects on antiatherosclerotic mediators. European Heart Journal 2011;32:226-7.

\section{Walther 2010 \{published data only\}}

Walther C, Fiess A. Preoperative exercise training is associated with less peri- and postoperative adverse events but similar long term outcome in patients with stable coronary artery disease. European Journal of Cardiovascular Prevention and Rehabilitation 2010; Vol. 17:S59.

\section{References to ongoing studies}

Alsaleh 2012 \{published data only\}

Alsaleh E, Blake $\mathrm{H}$, Windle R. Behavioural intervention to increase physical activity among patients with coronary heart disease: protocol for a randomised controlled trial. International Journal of Nursing Studies 2012;49:1489-93.

CTRI/2012/02/002408 \{unpublished data only\}

CTRI/2012/02/002408. A study on effectiveness of YOGA based cardiac rehabilitation programme in India and United Kingdom. http://apps.who.int/trialsearch/Trial2.aspx? TrialID=CTRI/2012/02/002408 (accessed 6 March 2015).

IRCT2014061418075N2 \{unpublished data only\} IRCT2014061418075N2. The Effect of a Cardiac Rehabilitation Program on Quality of Life in Acute Coronary Syndrome Patients. http://apps.who.int/trialsearch/Trial2.aspx? TrialID=IRCT2014061418075N2 (accessed 6 March 2015).

\section{JPRN-UMIN000005177 \{unpublished data only\}}

JPRN-UMIN000005177. Japanese prospective multicenter study on outpatient cardiac rehabilitation after the percutaneous coronary intervention. http://apps.who.int/trialsearch/ Trial2.aspx?TrialID=JPRN-UMIN000005177 (accessed 6 March 2015).

\section{JPRN-UMIN000010031 \{unpublished data only\}} JPRN-UMIN000010031. Impact of comprehensive cardiac rehabilitation program on stabilization of coronary plaque after acute coronary syndrome. http://apps.who.int/trialsearch/ Trial2.aspx?TrialID=JPRN-UMIN000010031 (acessed 6 March 2015).

NCT00725088 \{unpublished data only\}

NCT00725088. Study of Rehabilitation Therapy on Patients After Acute Myocardial Infarction. clinicaltrial.gov/NCT00725088 (accessed 6 March 2015).

NCT01916525 \{unpublished data only\} NCT01916525. Effectiveness of Exercise Cardiac Rehabilitation (EFEX-CARE). clinicaltrials.gov/NCT01916525 (accessed 6 March 2015).

NCT01941355 \{unpublished data only\}

NCT01941355. Trial of Rehabilitation in Phase 1 After Coronary Artery Bypass Grafting (SheppHeart). clinicaltrials.gov/ NCT01941355.

NCT02025257 \{unpublished data only\}

NCT02025257. Effects of Exercise in Patients With Coronary Artery Disease Aged 80 Years or Older. clinicaltrials.gov/ NCT02025257 (accessed 6 March 2015).

NCT02219815 \{unpublished data only\} NCT02219815. Pre-operative Rehabilitation for Reduction of Hospitalization After Coronary Bypass and Valvular Surgery. clinicaltrials.gov/NCT02219815 (accessed 6 March 2015).

NCT02235753 \{unpublished data only\}

NCT02235753. High-intensity Exercise After Acute Cardiac Event (HITCARE). clinicaltrials.gov/NCT02235753 (accessed 6 March 2015). 
Santaularia 2013 \{published data only\}

Santaularia N, Caminal J, Arnau A, Perramon M, Montesinos J, Trape J, et al. Randomized clinical trial to evaluate the effect of a supervised exercise training program on readmissions in patients with myocardial ischemia: A study protocol. BMC Cardiovascular Disorders 2013;13(1):32.

\section{Additional references}

\section{BACPR 2012}

British Association for Cardiovascular Prevention and Rehabilitation. The BACPR standards and core components for cardiovascular disease prevention and rehabilitation,2nd edition. http://www.bacpr.com/ resources/46C_BACPR_Standards_and_Core_Components_2012.pdf 2012 (accessed 27 January 2015).

\section{Balady 2011}

Balady GJ, Ades PA, Bittner VA, Franklin BA, Gordon NF, Thomas RJ, et al. Referral, enrollment, and delivery of cardiac rehabilitation/secondary prevention programs at clinical centers and beyond: a presidential advisory from the American Heart Association. Circulation 2011;124:2951-2960.

\section{Balshem 2011}

Balshem H, Helfand M, Schunemann HJ, Oxman AD, Kunz R, Brozek J, et al. GRADE guidelines: 3 . Rating the quality of evidence. Journal of Clinical Epidemiology 2011;64:401-6.

\section{Beswick 2004}

Beswick AD, Rees K, Griebsch I, Taylor FC, Burke M, West RR, et al. Provision, uptake and cost of cardiac rehabilitation programmes: improving services to under-represented groups. Health Technology Assessment 2004;8(iii-iv,ix-x):1-152.

\section{Bethell 2008}

Bethell H, Lewin R, Evans J, Turner S, Allender S, Petersen S. Outpatient cardiac rehabilitation attendance in England: variability by region and clinical characteristics. Journal of Cardiopulmonary Rehabilitation and Prevention 2008;28:386-91.

\section{Braunwald 2011}

Bonow RO, Mann DL, Zipes DP, Libby P. Braunwald's heart disease: a textbook of cardiovascular medicine. 9th Edition. Elsevier Saunders, 2011.

\section{Clark 2005}

Clark AM, Hartling L, Vandermeer B, McAlister FA. Metaanalysis:secondary prevention programs for patients with coronary artery disease. Annals of Internal Medicine 2005;143:659-672.

\section{Clark 2012}

Clark AM, King-Shier KM, Thompson DR, Spaling MA, Duncan AS, Stone JA, et al. A qualitative systematic review of influences on attendance at cardiac rehabilitation programs after referral. American Heart Journal 2012;164(6):835-845.

\section{Clausen 1976}

Clausen JP, Trap-Jensen J. Heart rate and arterial blood pressure during exercise in patients with angina pectoris: effects of exercise training and of nitroglycerin. Circulation 1976;53:436-42.

\section{Deeks 2011}

Deeks JJ, Higgins JPT, Altman DG (editors). Chapter 9: Analysing data and undertaking meta-analyses. In: Higgins JPT, Green S (editors). Cochrane Handbook for Systematic Reviews of Interventions Version 5.1.0 (updated March 2011). The Cochrane Collaboration, 2011. Available from www.cochranehandbook.org.

\section{Egger 1997}

Egger M, Davey Smith G, Schneider M, Minder C. Bias in meta-analysis detected by a simple graphical test. BMJ 1997;315:629-34.

\section{GRADEpro GDT 2015}

GRADEpro GTD: GRADEpro Guideline Development Tool [software]. McMaster University, 2015 (developed by Evidence Prime, Inc). Available from www.gradepro.org.

\section{Hambrecht 2000}

Hambrecht R, Wolff A, Gielen S, Linke A, Hofer J, Erbs S, et al. Effect of exercise on coronary endothelial function in patients with coronary artery disease. New England Journal of Medicine 2000;342:454-60.

\section{Heran 2008a}

Heran BS, Wong MM, Heran IK, Wright JM. Blood pressure lowering efficacy of angiotensin converting enzyme (ACE) inhibitors for primary hypertension. Cochrane Database of Systematic Reviews 2008, Issue 4. [DOI: 10.1002/14651858.CD003823.pub2]

\section{Heran 2008b}

Heran BS, Wong MMY, Heran IK, Wright JM. Blood pressure lowering efficacy of angiotensin receptor blockers for primary hypertension. Cochrane Database of Systematic Reviews 2008, Issue 4. [DOI: 10.1002/14651858.CD003822.pub2]

\section{Higgins 2003}

Higgins JPT, Thompson SG, Deeks JJ, Altman DG. Measuring inconsistency in meta-analyses. BMJ 2003;327(7414):557-60.

\section{Higgins 2011}

Higgins JPT, Altman DG, Sterne JAC (editors). Chapter 8: Assessing risk of bias in included studies. In: Higgins JPT, Green S (editors). Cochrane Handbook for Systematic Reviews of Interventions Version 5.1.0 (updated March 2011). The Cochrane Collaboration, 2011. Available from www.cochranehandbook.org.

\section{Karmali 2014}

Karmali KN, Davies P, Taylor F, Beswick A, Martin N, Ebrahim S. Promoting patient uptake and adherence in cardiac rehabilitation. Cochrane Database of Systematic Reviews 2014, Issue 6. [DOI: 10.1002/14651858.CD007131.pub3] 


\section{Lefebvre 2011}

Lefebvre C, Manheimer E, Glanville J. Chapter 6: Searching for studies. Cochrane Handbook for Systematic Reviews of Interventions Version 5.1.0 (updated March 2011).The Cochrane Collaboration, 2011. Available from www.cochranehandbook.org 2011.

\section{Liberati 2009}

Liberati A, Altman DG, Tetzlaff J, Mulrow C, Gotzsche PC, Ioannidis JP, et al. The PRISMA statement for reporting systematic reviews and meta-analyses of studies that evaluate health care interventions: explanation and elaboration. PLoS Medicine 2009;6:e1000100.

\section{Nichols 2012}

Nichols M, Townsend N, Luengo-Fernandez R, Leal J, Gray A, Scarborough P, et al. European Cardiovascular Disease Statistics. Brussels: European Heart Network, Brussels, European Society of Cardiology, Sophia Antipolis, 2012.

\section{Pavy 2006}

Pavy B, Iliou MC, Meurin P, Tabet JY, Corone S. Safety of exercise training for cardiac patients: results of the French registry of complications during cardiac rehabilitation. Arch Intern Med 2006;166:2329-34.

\section{Perk 2012}

Perk J, De Backer G, Gohlke H, Graham I, Reiner Z, Verschuren M, et al. European Association for Cardiovascular Prevention \& Rehabilitation(EACPR); ESC Committee for Practice Guidelines (CPG).European Guidelines on cardiovascular disease prevention in clinical practice (version 2012). The Fifth Joint Task Force of the European Society of Cardiology and Other Societies on Cardiovascular Disease Prevention in Clinical Practice (constituted by representatives of nine societies and by invited experts). European Heart Journal 2012;33(13):1635-1701.

\section{Piepoli 2004}

Piepoli MF, Davos C, Francis DP, Coats AJ. Exercise training meta-analysis of trials in patients with chronic heart failure (ExTraMATCH). BMJ 2004;328:189.

\section{RevMan 2014 [Computer program]}

The Nordic Cochrane Centre, The Cochrane Collaboration. Review Manager (RevMan) Version 5.3.. Copenhagen: The Nordic Cochrane Centre, The Cochrane Collaboration, 2014.

\section{Risom 2014}

Risom SS, Zwisler AD, Johansen PP, Sibilitz KL, Lindschou J, Taylor RS, et al. Exercise-based cardiac rehabilitation for adults with atrial fibrillation. Cochrane Database of Systematic Reviews 2014, Issue 7. [DOI: 10.1002/14651858.CD011197]

\section{Schünemann 2011}

Schünemann HJ, Oxman AD, Vist GE, Higgins JPT, Deeks JJ, Glasziou P, Guyatt GH. Chapter 12: Interpreting results and drawing conclusions. In: Higgins JPT, Green S (editors), Cochrane Handbook for Systematic Reviews of Interventions Version 5.1.0 (updated March 2011). The Cochrane
Collaboration, 2011. Available from www.cochranehandbook.org.

\section{Smith 2011}

Smith SC, Benjamin EJ, Bonow RO, Braun LT, Creager MA, Franklin BA, et al. AHA/ACCF secondary prevention and risk reduction therapy for patients with coronary and other atherosclerotic vascular disease: 2011 update: a guideline from the American Heart Association and American College of Cardiology Foundation endorsed by the World Heart Federation and the Preventive Cardiovascular Nurses Association. Journal of the American college of cardiology 2011;58(23):2432-2446.

\section{StataCorp 2013 [Computer program]}

StataCorp, College Station, TX: StataCorp LP. Stata Statistical Software: Release 13.. StataCorp, College Station, TX: StataCorp LP, 2013.

\section{Taylor 2006}

Taylor RS, Unal B, Critchley JA, Capewell S. Mortality reductions in patients receiving exercise-based cardiac rehabilitation: How much can be attributed to cardiovascular risk factors improvements?. European Journal of Cardiopulmonary Rehabilitation 2006;136:369-74.

\section{Taylor 2010}

Taylor RS, Dalal H, Jolly K, Moxham T, Zawada A. Homebased versus centre-based cardiac rehabilitation. Cochrane Database of Systematic Reviews 2010, Issue 1. [DOI: 10.1002/14651858.CD007130.pub2]

\section{Taylor 2014}

Taylor RS, Sagar VA, Davies EJ, Briscoe S, Coats AJS, Dalal $\mathrm{H}$, et al. Exercise-based rehabilitation for heart failure. Cochrane Database of Systematic Reviews 2014, Issue 4. [DOI: 10.1002/14651858.CD003331.pub4]

\section{Townsend 2012}

Townsend N, Wickramasinghe K, Bhatnagar P, Smolina K, Nichols M, Leal J, et al. Coronary heart disease statistics 2012 edition. British Heart Foundation. London, 2012:107.

\section{Unal 2004}

Unal B, Critchley J, Capewell S. Explaining the decline in coronary heart disease mortality in England and Wales between 1981 and 2000. Circulation 2004;109:1101-7.

\section{Van Camp 1986}

Van Camp SP, Peterson RA. Cardiovascular complications of outpatient cardiac rehabilitation programs. JAMA 1986;256:1160-3.

\section{WHO 2014}

World Health Organization. The top 10 causes of death. Fact sheet No. 310. http://www.who.int/mediacentre/factsheets/ fs310/en/ Updated May 2014. 


\section{References to other published versions of this review}

\section{Anderson 2015}

Anderson LA, Oldridge N, Thompson DR, Zwisler AD, Rees K, Martin N, et al. Exercise-based cardiac rehabilitation for coronary heart disease Cochrane systematic review and metaanalysis. Journal of the American College of Cardiology in press.

\section{Heran 2011}

Heran BS, Chen JM, Ebrahim S, Moxham T, Oldridge N, Rees K, et al. Exercise-based cardiac rehabilitation for coronary heart disease. Cochrane Database of Systematic Reviews 2011, Issue 7. [DOI: 10.1002/14651858.CD001800.pub2]

\section{Jolliffe 2001}

Jolliffe J, Rees K, Taylor RRS, Thompson DR, Oldridge N, Ebrahim S. Exercise-based rehabilitation for coronary heart

CHARACTERISTICS OF STUDIES

Characteristics of included studies [ordered by study ID] disease. Cochrane Database of Systematic Reviews 2001, Issue 1. [DOI: 10.1002/14651858.CD001800]

\section{Sibilitz 2014}

Sibilitz KL, Berg SK, Tang LH, Risom SS, Gluud C, Lindschou J, et al. Exercise-based cardiac rehabilitation for adults after heart valve surgery. Cochrane Database of Systematic Reviews 2013, Issue 12. [DOI: 10.1002/14651858.CD010876]

\section{Taylor 2004}

Taylor RS, Brown A, Ebrahim S, Jolliffe J, Noorani H, Rees K, et al. Exercise-based rehabilitation for patients with coronary heart disease: systematic review and meta-analysis of randomized controlled trials. American Journal of Medicine 2004;116(110):682-92.

* Indicates the major publication for the study

Andersen 1981

Study design: RCT
Country: Denmark
Dates patients recruited: NR
Maximum follow up: 37 months
Post MI randomised four weeks after discharge.

Participants Inclusion criteria: $<66 \mathrm{yrs}$ with 1 st MI.

Exclusion criteria: patients without motivation and patients with impairment of the motorial apparatus that excluded training.

N Randomised: total: 75 intervention: 38 ; comparator: 37

Diagnosis (\% of pts): post MI: $100 \%$

Age (mean $\pm \mathbf{S D}$ ): intervention: $52.2 \pm 7.5$; comparator: $55.6 \pm 6.3$

Percentage male: intervention: $100 \%$; comparator: $100 \%$

Ethnicity: NR

Interventions

Intervention: aerobic activity e.g. running, cycling, skipping + weights for 1 hour $\times 2$ weekly for 2 months, then $x 1$ week for 10 months. Then continue at home.

Components: exercise.

Setting: centre-based initially, followed by home.

Aerobic exercise:

Modality: e.g. running, cycling, skipping.

Length of session: 1 hour

Frequency: twice a week for two months, and then weekly for 10 months.

Intensity: initial load of $150 \mathrm{kpm} / \mathrm{min}(24.5 \mathrm{~W})$. increased with $150 \mathrm{kpm} / \mathrm{min}$ every 6 mins. 
Resistance training included? yes - weights.

Total duration: 12 months.

Co-interventions: none described

Comparator: non-trained group (although some patients trained on own initiative).

Co-interventions: none described.

\begin{tabular}{|c|c|}
\hline Outcomes & $\begin{array}{l}\text { Total \& CHD mortality. } \\
\text { Non fatal MI. } \\
\text { Outcomes measured at } 1,13,25, \& 37 \text { months post-discharge. }\end{array}$ \\
\hline Source of funding & NR \\
\hline Conflicts of interest & NR \\
\hline Notes & $\begin{array}{l}88 \text { participants were randomised, but } 13 \text { failed to follow up. Therefore } 75 \text { took part in the study. } \\
\text { Several participants in C trained on own initiative, but were analysed as intention to treat. } \\
\text { Authors concluded that physical training after MI appears to reduce consequences and to improve } \\
\text { PWC, but PWC declines once participant on their own } \\
\text { Physcial training had no effect on period of convalescence or return to work, but age and previous oc- } \\
\text { cupation were of significance. }\end{array}$ \\
\hline
\end{tabular}

\section{Risk of bias}

\begin{tabular}{|c|c|c|}
\hline Bias & Authors' judgement & Support for judgement \\
\hline $\begin{array}{l}\text { Random sequence genera- } \\
\text { tion (selection bias) }\end{array}$ & Low risk & "random numbers". \\
\hline $\begin{array}{l}\text { Allocation concealment } \\
\text { (selection bias) }\end{array}$ & Unclear risk & Allocation concealment not reported. \\
\hline $\begin{array}{l}\text { Blinding of outcome as- } \\
\text { sessment (detection bias) } \\
\text { All outcomes }\end{array}$ & Unclear risk & Blinding not described. \\
\hline $\begin{array}{l}\text { Incomplete outcome data } \\
\text { (attrition bias) } \\
\text { All outcomes }\end{array}$ & High risk & $15 \%$ lost to follow-up, no description of withdrawals or dropouts. \\
\hline $\begin{array}{l}\text { Selective reporting (re- } \\
\text { porting bias) }\end{array}$ & Low risk & All outcomes were reported at all time points. \\
\hline $\begin{array}{l}\text { Groups balanced at base- } \\
\text { line }\end{array}$ & Low risk & No significant differences in "basic data" for training and control patients. \\
\hline $\begin{array}{l}\text { Intention-to-treat analysis } \\
\text { conducted }\end{array}$ & Low risk & Yes. \\
\hline $\begin{array}{l}\text { Groups received same } \\
\text { treatment (apart from the } \\
\text { intervention) }\end{array}$ & Low risk & Intervention included exercise only. \\
\hline
\end{tabular}




\section{Dates patients recruited: NR}

Maximum follow up: 1 year

Participants

Inclusion criteria: Patients 3 to 8 weeks after MI, unstable angina or reconstructive coronary arteries intervention. In some cases (at discretion of the researchers) patients with stable angina after hospital treatment with unconfirmed diagnosis of MI or unstable angina were included in the study.

Exclusion criteria: none reported

N Randomised: total: 392; intervention: 197; comparator: 195

Diagnosis (\% of pts):

Stable angina: intervention: 62.7; comparator: 77.7

Post MI: intervention: 78.4; comparator: 77.3

Unstable angina: intervention: 5.0; comparator: 10.9

(not mutually exclusive).

Age (mean \pm SD): intervention: $51.9 \pm 7.2$; comparator: $51.9 \pm 7$

Percentage male: intervention: 95.5; comparator: 91.7

Ethnicity: NR

Intervention: Patients of the main group received moderate-intensity PT (50-60\% of the performed capacity by bicycle ergometry (BE) test) 3 times per week with duration of exercises from 45 minutes to 1 hour for 1 year.

Components: exercise only.

Setting: NR

Aerobic exercise:

Modality: cycling.

Length of session: $45-60$ mins.

Frequency: 3 times a week.

Intensity: $50-60 \%$ of the performed capacity by bicycle ergometry test.

\section{Resistance training included? No.}

Total duration: 1 year.

Co-interventions: patients received standard medical therapy described below.

Comparator: Patients received standard medical therapy which included beta-blocker, acetylsalicylic acid or other antithrombotic drug, as well as nitrate, and ACE inhibitor. Some patients took lipid-lowering drugs.

Co-interventions: none described

Outcomes Mortality and MI


Aronov 2010 (Continued)

\begin{tabular}{ll} 
Source of funding & NR \\
\hline Conflicts of interest & NR \\
\hline Notes &
\end{tabular}

\section{Risk of bias}

\begin{tabular}{|c|c|c|}
\hline Bias & Authors' judgement & Support for judgement \\
\hline $\begin{array}{l}\text { Random sequence genera- } \\
\text { tion (selection bias) }\end{array}$ & Unclear risk & $\begin{array}{l}\text { Method of randomisation not described...."patients were randomised into } 2 \\
\text { groups....". }\end{array}$ \\
\hline $\begin{array}{l}\text { Allocation concealment } \\
\text { (selection bias) }\end{array}$ & Unclear risk & Allocation concealment not described. \\
\hline $\begin{array}{l}\text { Blinding of outcome as- } \\
\text { sessment (detection bias) } \\
\text { All outcomes }\end{array}$ & Unclear risk & Blinding of assessments not described. \\
\hline $\begin{array}{l}\text { Incomplete outcome data } \\
\text { (attrition bias) } \\
\text { All outcomes }\end{array}$ & Low risk & Withdrawals were similar for both groups. \\
\hline $\begin{array}{l}\text { Selective reporting (re- } \\
\text { porting bias) }\end{array}$ & Low risk & All outcomes were reported at all time points. \\
\hline $\begin{array}{l}\text { Groups balanced at base- } \\
\text { line }\end{array}$ & Low risk & $\begin{array}{l}\text { "the groups did not differ in major clinical, anamnesis and functional indica- } \\
\text { tors." }\end{array}$ \\
\hline $\begin{array}{l}\text { Intention-to-treat analysis } \\
\text { conducted }\end{array}$ & Unclear risk & $\begin{array}{l}\text { Intention-to-treat analysis is not reported, no details of how missing data is } \\
\text { handled, and no Ns are given in the results tables. }\end{array}$ \\
\hline $\begin{array}{l}\text { Groups received same } \\
\text { treatment (apart from the } \\
\text { intervention) }\end{array}$ & Low risk & Both groups received standard medical therapy. \\
\hline
\end{tabular}

Belardinelli 2001

\begin{tabular}{ll} 
Methods & Study design: Single centre RCT \\
Country: Italy & \\
& Dates patients recruited: NR \\
& Maximum follow up: 33 (SD 7) months \\
\hline Participants & $\begin{array}{l}\text { Inclusion criteria: Successful procedure of coronary angioplasty in } 1 \text { or } 2 \text { native epicardial coronary ar- } \\
\text { teries and ability to exercise. }\end{array}$ \\
& $\begin{array}{l}\text { Exclusion criteria: Previous coronary artery procedures, cardiogenic shock, unsuccessful angioplasty } \\
\text { (defined as residual stenosis }>30 \% \text { of initial value), complex ventricular arrhythmias, uncontrolled hy- } \\
\text { pertension and diabetes mellitus, creatinine }>2.5 \text { mg/dl, orthopedic or neurological limitations to exer- } \\
\text { cise or unstable angina after procedure and before enrolment. }\end{array}$
\end{tabular}

N Randomised: total:118; intervention: 59; comparator: 59 
Belardinelli 2001 (Continued)

\section{Diagnosis (\% of pts):}

Myocardial Infarction: intervention: 51; comparator: 47

Hypercholesterolemia: intervention: 61; comparator: 54

Diabetes: intervention: 17; comparator: 20

Hypertension: intervention: 42; comparator: 47

LVEF (\%): intervention: 52 (SD 16); comparator: 50 (SD 14)

Age (mean \pm SD): intervention: $53 \pm 11$; comparator: $59 \pm 10$

Percentage male: intervention: $83.1 \%$; comparator: $84.8 \%$

Percentage white: NR

Interventions

Intervention: Exercise sessions were performed at the hospital gym and were supervised by a cardiologist. After a 15-min phase of stretching and calisthenics, patients pedalled on an electronically braked cycle ergometer at the target work rate for $30 \mathrm{~min}$. This working phase was preceded by a 5 -min loadless warm-up and followed by $3 \mathrm{~min}$ of unloaded cool-down pedaling.

Components: exercise only.

Setting: supervised in hospital gym.

\section{Aerobic exercise:}

Modality: electronically braked cycle ergometer.

Length of session: $53 \mathrm{~min}$.

Frequency: 3 sessions/week.

Intensity: $60 \%$ of peak oxygen uptake $\left(\mathrm{VO}_{2}\right)$.

Resistance training included? Yes - calisthenics.

Total duration: six months.

Co-interventions: none described.

Comparator: Control patients were recommended to perform basic daily mild physical activities but to avoid any physical training. A list of acceptable physical activities was provided, together with a diary to report daily activities.

Co-interventions: none described.

Outcomes

Cardiac mortality; myocardial infarction; coronary angioplasty (percutaneous transluminal coronary angioplasty, coronary stent); coronary artery bypass graft; health-related quality of life: MOS ShortForm General Health Survey.

Source of funding NR

Conflicts of interest

NR

Notes

\section{Risk of bias}


Belardinelli 2001 (Continued)

Random sequence genera- Unclear risk $\quad$ Not reported.
tion (selection bias)

\begin{tabular}{ll}
\hline $\begin{array}{l}\text { Allocation concealment } \\
\text { (selection bias) }\end{array}$ & Unclear risk
\end{tabular}

\begin{tabular}{lll}
\hline $\begin{array}{l}\text { Blinding of outcome as- } \\
\text { sessment (detection bias) } \\
\text { All outcomes }\end{array}$ & Unclear risk & Blinding not described. \\
\hline $\begin{array}{l}\text { Incomplete outcome data } \\
\text { (attrition bias) } \\
\text { All outcomes }\end{array}$ & High risk & Cardiac events of 12 patients who were excluded not accounted for. \\
\hline $\begin{array}{l}\text { Selective reporting (re- } \\
\text { porting bias) }\end{array}$ & Low risk & All outcomes were reported at all time points. \\
\hline $\begin{array}{l}\text { Groups balanced at base- } \\
\text { line }\end{array}$ & Low risk & Groups were well balanced for pathophysiological and clinical variables. \\
\hline $\begin{array}{l}\text { Intention-to-treat analysis } \\
\text { conducted }\end{array}$ & Low risk & Yes. \\
\hline $\begin{array}{l}\text { Groups received same } \\
\text { treatment (apart from the } \\
\text { intervention) }\end{array}$ & Low risk & Both the exercise and the control groups were subjected to the same \\
\hline
\end{tabular}

\section{Bell 1998}

Methods

Study design: Multicentre RCT ( 5 sites), participants randomised 4 to 6 days post-event.

Two independent 2-way evaluations: conventional CR versus the Heart Manual (HM) and HM versus usual care.

Country: UK

Dates patients recruited: NR

Maximum follow up: 1 year

Participants

Inclusion criteria: Post $\mathrm{MI}<65$ years

Exclusion criteria: NR

N Randomised: total: 353; intervention: 251; comparator: 102

Diagnosis (\% of pts): MI: $100 \%$

Age (mean \pm SD): for women: $60.7 \pm 7.2$ to $64.3 \pm 7.3$; for men: $57.8 \pm 8.9$ to $59.4 \pm 9.4$

Percentage male: $78 \%$

Ethnicity: NR

Interventions Intervention:

Heart Manual Group: The Heart Manual is a comprehensive home-based programme which includes an exercise regimen, relaxation and stress management techniques, specific self-help treatments for psychological problems commonly experienced by MI patients and advice on coronary risk-related behaviours. 
Bell 1998 (Continued)

Components: exercise, education and psychological.

Setting: home

Aerobic exercise:

Modality: walking

Length of session: NR

Frequency: NR

Intensity: NR

Resistance training included? NR

Total duration: up to 6 weeks

Co-interventions: Relaxation and stress management techniques, specific self-help treatments for psychological problems commonly experienced by MI patients and advice on coronary risk-related behaviours.

Conventional CR Group: 1 to 2 group classes per week, walking etc other days for 8-12 weeks with multidisciplinary team.

Comparator: usual care.

Co-interventions: none described.

Outcomes Total mortality, health-related quality of life: Nottingham Health Profile.

\begin{tabular}{|c|c|c|}
\hline Source of funding & \multicolumn{2}{|l|}{ NR } \\
\hline Conflicts of interest & \multicolumn{2}{|l|}{ NR } \\
\hline Notes & \multicolumn{2}{|c|}{$\begin{array}{l}\text { Hospital readmissions significantly reduced in Heart Manual group compared with conventional CR } \\
\text { and control in initial six-month period. }\end{array}$} \\
\hline \multicolumn{3}{|l|}{ Risk of bias } \\
\hline Bias & Authors' judgement & Support for judgement \\
\hline $\begin{array}{l}\text { Random sequence genera- } \\
\text { tion (selection bias) }\end{array}$ & Low risk & $\begin{array}{l}\text { "Randomisation was achieved by providing each hospital with a series of } \\
\text { sealed envelopes containing cards evenly distributed between conditions. The } \\
\text { envelopes were taken sequentially and, before opening the envelope, the pa- } \\
\text { tient's surname was written diagonally across the sealed flap, in such a way } \\
\text { that when the envelope was opened the name was 'torn in two'. Opened en- } \\
\text { velopes were retained and returned to the trial coordinator. The importance } \\
\text { of remaining neutral when advising the patients of the outcome of randomi- } \\
\text { sation was emphasised in the written protocol and was reinforced during the } \\
\text { sessions which were held to familiarise facilitators with the protocol." }\end{array}$ \\
\hline
\end{tabular}

Allocation concealment Low risk (selection bias)

\begin{abstract}
"Randomisation was achieved by providing each hospital with a series of sealed envelopes containing cards evenly distributed between conditions. The envelopes were taken sequentially and, before opening the envelope, the patient's surname was written diagonally across the sealed flap, in such a way that when the envelope was opened the name was 'torn in two'. Opened envelopes were retained and returned to the trial coordinator. The importance of remaining neutral when advising the patients of the outcome of randomisation was emphasised in the written protocol and was reinforced during the sessions which were held to familiarise facilitators with the protocol."
\end{abstract}


Bell 1998 (Continued)

Comment: Patients were informed of outcome of randomisation.

\begin{tabular}{lll}
\hline $\begin{array}{l}\text { Blinding of outcome as- } \\
\text { sessment (detection bias) } \\
\text { All outcomes }\end{array}$ & Unclear risk & Blinding not described \\
\hline $\begin{array}{l}\text { Incomplete outcome data } \\
\text { (attrition bias) }\end{array}$ & Low risk & $\begin{array}{l}1.5 \% \text { lost to follow up and reported description of withdrawals and/or } \\
\text { dropouts. }\end{array}$ \\
\hline
\end{tabular}

All outcomes

Selective reporting (re- Low risk All outcomes were reported at all time points.
porting bias)
porting bias)

\begin{tabular}{lll}
\hline $\begin{array}{l}\text { Groups balanced at base- } \\
\text { line }\end{array}$ & Unclear risk & Full text no longer available. \\
\hline $\begin{array}{l}\text { Intention-to-treat analysis } \\
\text { conducted }\end{array}$ & Unclear risk & Full text no longer available. \\
\hline $\begin{array}{l}\text { Groups received same } \\
\text { treatment (apart from the } \\
\text { intervention) }\end{array}$ & Unclear risk & Full text no longer available. \\
\hline
\end{tabular}

Methods Study design: Single centre RCT

Country: Sweden

Dates patients recruited: October 1973 to January 1975

Maximum follow up: 14 months

Participants Inclusion criteria: patients $>65$ years with MI.

Exclusion criteria: Severe cardiac failure, PMI-syndrome, aortic regurgitation, cerebral infarct hemiparesis, disease of hip, status post-poliomyelitis, amputation of lower extremity, diabetes with retinopathy, hyper/hypo thyroidism, hyperparathyroidism, mental illness.

N Randomised: total: 87; intervention: 44; comparator: 43

Diagnosis (\% of pts): AMI: $100 \%$

Age (years \pm SD): intervention: $55.3 \pm 6.6$; comparator: $57.1 \pm 6.6$

Percentage male: $85 \%$

Ethnicity: NR

Interventions

Intervention: Physical training under the supervision of a specially trained physiotherapist attached to the cardiological unit. Exercises consisted of interval training of large muscle groups on a mechanically braked ergometer bicycle, calisthenics and jogging for 30 minutes twice weekly over a period of 3 months. The intensity of the exercises was graded individually on the basis of the findings at the exercise tolerance test, and a maximum heart rate at exercise was prescribed.

Components: exercise, counselling and social measures.

Setting: supervised at the cardiological unit.

\section{Aerobic exercise:}


Modality: ergometer cycling.

Length of session: $30 \mathrm{~min}$.

Frequency: twice per week.

Intensity: $90 \%$ of the max heart rate at the exercise tolerance test.

Resistance training included? interval training of large muscle groups, callisthenics.

Total duration: 3 months.

Co-interventions: Counselling was given, supplying practical information on avoiding weight gain, to stop smoking, to keep on with the physical exercise and to resume leisure activities as much as possible.

Comparator: conventional care.

Co-interventions: none described.

\begin{tabular}{ll}
\hline Outcomes & Total mortality, CHD mortality, non-fatal MI up to average 14 months. \\
\hline Source of funding & NR \\
\hline Conflicts of interest & NR \\
\hline Notes & $\begin{array}{l}\text { Most emphasis on social/ psychological aspects. } \\
\text { to take part in the rehab programme - 45 patients were excluded at this point. Seven of intervention } \\
\text { group declined to take part, but six of these were seen at follow up and included in the analysis be- } \\
\text { cause "control group probably had a comparable number who would have declined further treat- } \\
\text { ment." }\end{array}$ \\
\hline
\end{tabular}

\section{Risk of bias}

\begin{tabular}{|c|c|c|}
\hline Bias & Authors' judgement & Support for judgement \\
\hline $\begin{array}{l}\text { Random sequence genera- } \\
\text { tion (selection bias) }\end{array}$ & Unclear risk & "allocated at random". \\
\hline $\begin{array}{l}\text { Allocation concealment } \\
\text { (selection bias) }\end{array}$ & Unclear risk & Not reported. \\
\hline $\begin{array}{l}\text { Blinding of outcome as- } \\
\text { sessment (detection bias) } \\
\text { All outcomes }\end{array}$ & Unclear risk & Blinding not described. \\
\hline $\begin{array}{l}\text { Incomplete outcome data } \\
\text { (attrition bias) } \\
\text { All outcomes }\end{array}$ & High risk & $\begin{array}{l}\text { Description of withdrawals \& dropouts: Intervention Group } 29 \% \text {; Control group } \\
33 \% \text { lost to follow up from } 126 \text { who took part. } 171 \text { were randomised and then } \\
45 \text { excluded by cardiologist. }\end{array}$ \\
\hline $\begin{array}{l}\text { Selective reporting (re- } \\
\text { porting bias) }\end{array}$ & Low risk & All outcomes were reported at all time points. \\
\hline $\begin{array}{l}\text { Groups balanced at base- } \\
\text { line }\end{array}$ & Low risk & $\begin{array}{l}\text { "No significant differences with regard to age, sex, number of infarcts, highest } \\
\text { serum glutamic oxaloacetic transaminase value, heart size on X-ray, or number } \\
\text { of days in hospital existed between the two groups". }\end{array}$ \\
\hline
\end{tabular}


Bengtsson 1983 (Continued)

Intention-to-treat analysis Low risk Yes. conducted

Groups received same treatment (apart from the intervention)
High risk

ren risk

"The program comprised.... Physical training supervised by a physiotherapist; counselling, individually and in groups; counselling of members of the family; social measures".

\section{Bertie 1992}

Methods

Study design: Single centre RCT; patients were randomised on day of discharge after MI.

Country: UK

Dates patients recruited: NR

Maximum follow up: 24 months

Participants

Inclusion criteria: Men and women with AMI.

Exclusion criteria: Uncontrolled heart failure; serious rhythm disturbances which persisted and required treatment at time of discharge; another disabling disease.

N Randomised: total: 110; intervention: 57; comparator: 53

Diagnosis (\% of pts): AMI: $100 \%$

Age (mean \pm SD): Intervention: $52.1 \pm 1.3$; Comparator: $52.7 \pm 1.3$

Percentage male: NR

Ethnicity: NR

Interventions

Exercise: A formal rehabilitation programme at the hospital started 3 weeks post-discharge. The programme concentrated mainly on standard pulse-monitored group exercise, supervised by a physiotherapist. The patient completed a circuit of 12 exercises, and after a five minute interval they repeated the circuit up to a maximum of four circuits.

Components: exercise.

Setting:supervised group sessions in the hospital gymnasium.

\section{Aerobic exercise:}

Modality: "group exercises".

Length of session: NR

Frequency: twice per week.

Intensity: NR

Total duration: 4 weeks.

Co-interventions: health, smoking and dietary advice and a relaxation technique.

Comparator: standard hospital care.

Co-interventions: All patients were asked to stop smoking and given dietary advice either for weight reduction or because of elevated serum cholesterol. To boost confidence each patient was asked to walk up two flights of stairs under supervision and was given advice on mobilisation on discharge. 
Bertie 1992 (Continued)

Outcomes

Total mortality, non-fatal MI, revascularisation; assessments at day of discharge, 3rd week after discharge; after rehabilitation (for intervention group); four months after infarct and 12-24 months after infarct).

\begin{tabular}{ll}
\hline Source of funding & NR \\
\hline Conflicts of interest & NR \\
\hline Notes &
\end{tabular}

\section{Risk of bias}

\begin{tabular}{|c|c|c|}
\hline Bias & Authors' judgement & Support for judgement \\
\hline $\begin{array}{l}\text { Random sequence genera- } \\
\text { tion (selection bias) }\end{array}$ & Unclear risk & "randomised". \\
\hline $\begin{array}{l}\text { Allocation concealment } \\
\text { (selection bias) }\end{array}$ & Unclear risk & Not reported. \\
\hline $\begin{array}{l}\text { Blinding of outcome as- } \\
\text { sessment (detection bias) } \\
\text { All outcomes }\end{array}$ & Unclear risk & Blinding not described. \\
\hline $\begin{array}{l}\text { Incomplete outcome data } \\
\text { (attrition bias) } \\
\text { All outcomes }\end{array}$ & High risk & $24 \%$ lost to follow-up, no description of withdrawals or dropouts. \\
\hline $\begin{array}{l}\text { Selective reporting (re- } \\
\text { porting bias) }\end{array}$ & Low risk & All outcomes were reported at all time points. \\
\hline $\begin{array}{l}\text { Groups balanced at base- } \\
\text { line }\end{array}$ & Low risk & $\begin{array}{l}\text { "The differences in age and employment between the two groups were not sig- } \\
\text { nificant". }\end{array}$ \\
\hline $\begin{array}{l}\text { Intention-to-treat analysis } \\
\text { conducted }\end{array}$ & High risk & No. \\
\hline $\begin{array}{l}\text { Groups received same } \\
\text { treatment (apart from the } \\
\text { intervention) }\end{array}$ & Low risk & $\begin{array}{l}\text { Patients were randomised into two groups: one for experimental rehabilita- } \\
\text { tion and a control group to receive standard hospital care......all patients were } \\
\text { asked to stop smoking and given dietary advice either for weight reduction or } \\
\text { because of elevated serum cholesterol". }\end{array}$ \\
\hline
\end{tabular}

\section{Bethell 1990}

\begin{tabular}{ll}
\hline Methods & Study design: Single centre RCT \\
Country: UK & Dates patients recruited: 1 December 1979 to March 1984 \\
& Maximum follow up: 5 years \\
\hline Participants & $\begin{array}{l}\text { Inclusion criteria: }<65 \text { yrs post Ml; history of chest pain typical of MI, progressive ECG changes, rise and } \\
\text { fall in aspartate transaminase concentrations with at least one reading above } 40 \text { units/ml. }\end{array}$
\end{tabular}


Bethell 1990 (Continued)

Exclusion criteria: Medical or orthopaedic problems that precluded their taking part in the exercise course; insulin-dependent diabetes mellitus; atrial fibrillation; on investigator's personal general practice list.

N Randomised: total: 200; intervention: 99; comparator: 101

Diagnosis (\% of pts): MI: $100 \%$

Age (mean \pm SD): intervention: $54.2 \pm 7.2$; comparator: $54.2 \pm 7.2$

Percentage male: intervention: $100 \%$; comparator: $100 \%$

Ethnicity: NR

\begin{tabular}{|c|c|}
\hline Interventions & $\begin{array}{l}\text { Intervention: Treatment patients entered a three-month course of three times a week circuit training. } \\
\text { Components: exercise only } \\
\text { Setting: centre } \\
\text { Aerobic exercise: } \\
\text { Modality: } 8 \text { stage circuit aerobic training. } \\
\text { Length of session: NR } \\
\text { Frequency: } 3 \text { times a week. } \\
\text { Intensity: } 70-85 \% \text { predicted HR max. } \\
\text { Resistance training included? weight training. } \\
\text { Total duration: } 3 \text { months. } \\
\text { Co-interventions: NR } \\
\text { Comparator: Patients were given a short talk on the sort of exercise that they might safely take unsu- } \\
\text { pervised. } \\
\text { Co-interventions: NR }\end{array}$ \\
\hline Outcomes & $\begin{array}{l}\text { Total mortality, CHD mortality, non fatal MI } \\
\text { (11 year follow up published in } 1999.5 \text { year follow up data from unpublished material used for meta } \\
\text { analysis.) }\end{array}$ \\
\hline Source of funding & British Heart Foundation and Wessex Regional Health Authority \\
\hline Conflicts of interest & NR \\
\hline Notes & $\begin{array}{l}229 \text { patients were randomised; } 14 \text { in the intervention group and } 15 \text { in control dropped out before the } \\
\text { first exercise test due to death, refusal or other problems. Therefore } 200 \text { took part in the study. } \\
\text { Cardiac mortality of } 3 \% \text { pa, once patients survived to be in the trial. Suggests more severely affected } \\
\text { patients were not included. } \\
\text { Significant predictors of cardiac death were pulmonary oedema on admission, complications during } \\
\text { admission, one or more previous infarcts, increasing age and low initial fitness. }\end{array}$ \\
\hline
\end{tabular}

\section{Risk of bias}

\begin{tabular}{lll}
\hline Bias & Authors' judgement & Support for judgement \\
\hline $\begin{array}{l}\text { Random sequence genera- } \\
\text { tion (selection bias) }\end{array}$ & Low risk & Random letter sequence. \\
\hline
\end{tabular}


Bethell 1990 (Continued)

$\begin{aligned} & \text { Allocation concealment } \\ & \text { (selection bias) }\end{aligned}$ Unclear risk Not reported.

\begin{tabular}{lll}
\hline Blinding of outcome as- & Unclear risk & Blinding not described.
\end{tabular}

All outcomes

Incomplete outcome data High risk $\quad 16 \%$ lost to follow up, no description of withdrawals or dropouts.
(attrition bias)

All outcomes

Selective reporting (re- Low risk $\quad$ All outcomes were reported at all time points. porting bias)

\begin{tabular}{ll}
\hline $\begin{array}{l}\text { Groups balanced at base- } \\
\text { line }\end{array}$ & Low risk \\
& $\begin{array}{l}\text { "The two groups were comparable in terms of age, presence of Q waves on the } \\
\text { electrocardiogram, aspartate transaminase concentration, presence of pul- } \\
\text { monary oedema, presence of complications, initial Vo2 max, and time to re- } \\
\text { turn to work". }\end{array}$
\end{tabular}

\begin{tabular}{lll}
\hline $\begin{array}{l}\text { Intention-to-treat analysis } \\
\text { conducted }\end{array}$ & High risk & No. \\
\hline $\begin{array}{l}\text { Groups received same } \\
\text { treatment (apart from the } \\
\text { intervention) }\end{array}$ & Low risk & $\begin{array}{l}\text { "Control patients were given a short talk on the sort of exercise that they } \\
\text { might safely take unsupervised. Treatment patients entered a three-month } \\
\text { course of three times a week circuit training at Alton Sports Centre." }\end{array}$ \\
\hline
\end{tabular}

\section{Bettencourt 2005}

Methods Study design: Single centre RCT (1:3 randomisation)

Country: Portugal

Dates patients recruited: September 1, 2001 to December 31, 2002

Maximum follow up: 1 year

Participants Inclusion criteria: Patients without previous cardiological follow-up, with $>4$ years' education, following hospitalisation for acute coronary syndrome (ACS).

Exclusion criteria: none stated.

N Randomised: total: 126; intervention: 31; comparator: 95

\section{Diagnosis (\% of pts):}

Unstable angina: intervention 20; comparator: 27

Non-Q wave MI: intervention 33; comparator: 31

Anterior MI: intervention 23; comparator: 20

Inferior MI: intervention 24; comparator: 21

MI of undetermined location: intervention 10; comparator 11

Age (years): intervention: 56 (range: 31-80); comparator: 58 (range: 33-86)

Percentage male: intervention: $84 \%$; comparator $83 \%$ 
Bettencourt 2005 (Continued)

\section{Ethnicity: NR}

Interventions

Intervention: The sessions took place in the hospital's gymnasium under qualified supervision. They consisted of a warm-up period at the beginning of each session, 20 to 30 minutes on a treadmill or ergometric bicycle and a recovery period with low intensity activities. The exercise program was initially based on the maximum heart rate reached on the exercise test prior to beginning the programme (performed on average five weeks after the ACS).

Components: exercise only.

Setting: aerobic exercise in supervised group sessions.

\section{Aerobic Exercise:}

Modality: treadmill and bicycle.

Length of session: 60 minutes.

Frequency: 3 times/week.

Intensity: NR

\section{Resistance training included? No.}

Total duration: 12 weeks, followed by one session a month for the remainder of the year.

Co-interventions: none described.

Comparator: Standard follow-up consisting of a mean of 3.5 consultations per year following the first event

Co-interventions: none described.

\begin{tabular}{|c|c|c|}
\hline Outcomes & \multicolumn{2}{|l|}{ HRQL } \\
\hline Source of funding & \multicolumn{2}{|c|}{ The Commission to Foster Health Care Research } \\
\hline Conflicts of interest & \multicolumn{2}{|l|}{ NR } \\
\hline \multicolumn{3}{|l|}{ Notes } \\
\hline \multicolumn{3}{|l|}{ Risk of bias } \\
\hline Bias & Authors' judgement & Support for judgement \\
\hline $\begin{array}{l}\text { Random sequence genera- } \\
\text { tion (selection bias) }\end{array}$ & Unclear risk & $\begin{array}{l}\text { "...the patients were randomly allocated to our hospital's cardiac rehabilita- } \\
\text { tion program or standard cardiological follow-up." }\end{array}$ \\
\hline $\begin{array}{l}\text { Allocation concealment } \\
\text { (selection bias) }\end{array}$ & High risk & Allocation concealment not described. \\
\hline $\begin{array}{l}\text { Blinding of outcome as- } \\
\text { sessment (detection bias) } \\
\text { All outcomes }\end{array}$ & High risk & "nature of the intervention being assessed did not permit blinding". \\
\hline $\begin{array}{l}\text { Incomplete outcome data } \\
\text { (attrition bias) } \\
\text { All outcomes }\end{array}$ & Low risk & There was no loss to follow up. \\
\hline $\begin{array}{l}\text { Selective reporting (re- } \\
\text { porting bias) }\end{array}$ & Low risk & $\begin{array}{l}\text { All outcomes described in the methods were reported in the results section for } \\
\text { both time points. }\end{array}$ \\
\hline
\end{tabular}


Bettencourt 2005 (Continued)

Groups balanced at base- Low risk "There were no significant differences between the two groups in any of the line baseline clinical or demographic characteristics studied (Table I), nor in any of the variables evaluated by the questionnaires during hospitalization."
Intention-to-treat analysis Low risk
ITT conducted.

conducted

\begin{tabular}{|c|c|c|}
\hline $\begin{array}{l}\text { Groups received same } \\
\text { treatment (apart from the } \\
\text { intervention) }\end{array}$ & Low risk & $\begin{array}{l}\text { "Besides standard cardiological follow-up in accordance with our depart- } \\
\text { ment's usual procedures, the cardiac rehabilitation program group had three } \\
60 \text { minute-sessions per week for the first } 12 \text { weeks, followed by one session a } \\
\text { month for the remainder of the year." }\end{array}$ \\
\hline
\end{tabular}

Briffa 2005

Methods Study design: Multicentre open RCT (2 sites)

Country: Australia

Dates patients recruited: 2 year period. No dates given.

Maximum follow up: 1 year.

Participants

Inclusion criteria: Uncomplicated acute myocardial infarction (AMI) or recovery from unstable angina aged under 75 years, self-caring, adequately literate in the English language, residing in the geographical area of the health service.

Exclusion criteria: Presentation with uncompensated heart failure, uncontrolled arrhythmias, severe and symptomatic aortic stenosis, or other conditions precluding physical activity.

N Randomised: total: 113; intervention: 57; comparator: 56

Diagnosis (\% of pts):

AMI: intervention 36.8; comparator 48.2

Unstable angina: intervention 63.2; comparator 51.8

Thrombolytic therapy: intervention 14.0; comparator 25.0

PCI/CAGS: intervention 59.6; comparator 46.4

Prior AMI, $\mathrm{PCI}, \mathrm{CAGS}$ : intervention 36.8; comparator 50.0

Age (Mean \pm SD): intervention: $60.8 \pm 8.7$; comparator: $61.9 \pm 9.4$

Percentage male: intervention $72 \%$; comparator $75 \%$

Ethnicity: NR

Interventions

Intervention: Comprehensive exercise-based outpatient cardiac rehabilitation.

Components: exercise plus education plus psychosocial counselling.

Setting: hospital-based, supervised exercise.

\section{Aerobic exercise:}

Modality: aerobic circuit training interspaced with resistance training.

Length of session: $60-90$ minutes.

Frequency: 3 times per week. 
Briffa 2005 (Continued)

\section{Intensity: NR \\ Resistance training included? no.}

Total duration: 6 weeks.

Co-interventions: 45 minutes of education (12 occasions) and 45 minutes of psychosocial counselling (6 occasions). If necessary, additional one-on-one counselling was provided.

Comparator: Conventional care: patients from both groups received individualised medical treatment including non-invasive and invasive cardiological procedures, surgical revascularisation, pharmacotherapy, and lifestyle counselling as determined by their usual doctors.

Co-interventions: none described ("Access to community cardiac rehabilitation programs was limited for the conventional management group").

\begin{tabular}{ll}
\hline Outcomes & Costs, HRQL \\
\hline Source of funding & $\begin{array}{l}\text { University of Sydney, the Cardiac Society of Australia and New Zealand, and the National Heart Foun- } \\
\text { dation of Australia; NHMRC; Department of Cardiology, Royal Prince Alfred Hospital. }\end{array}$ \\
\hline Conflicts of interest & "None identified" \\
\hline Notes &
\end{tabular}

\section{Risk of bias}

\begin{tabular}{|c|c|c|}
\hline Bias & Authors' judgement & Support for judgement \\
\hline $\begin{array}{l}\text { Random sequence genera- } \\
\text { tion (selection bias) }\end{array}$ & Low risk & "...randomisation using dynamic balancing was performed". \\
\hline $\begin{array}{l}\text { Allocation concealment } \\
\text { (selection bias) }\end{array}$ & Low risk & $\begin{array}{l}\text { "Central randomisation of participants was performed at the National Health } \\
\text { and Medical Research Council Clinical Trials Centre". }\end{array}$ \\
\hline $\begin{array}{l}\text { Blinding of outcome as- } \\
\text { sessment (detection bias) } \\
\text { All outcomes }\end{array}$ & High risk & "Open" trial so we assume that outcomes were not blinded. \\
\hline $\begin{array}{l}\text { Incomplete outcome data } \\
\text { (attrition bias) } \\
\text { All outcomes }\end{array}$ & Low risk & $\begin{array}{l}\text { One person was lost to follow up and } 5 \text { patients changed groups; } 2 \text { patients } \\
\text { were excluded from each group i.e. } 4 / 113(4 \%) \text {. }\end{array}$ \\
\hline $\begin{array}{l}\text { Selective reporting (re- } \\
\text { porting bias) }\end{array}$ & Low risk & All outcomes described in the methods section are reported in results. \\
\hline $\begin{array}{l}\text { Groups balanced at base- } \\
\text { line }\end{array}$ & Low risk & "The randomised groups were well balanced for baseline characteristics". \\
\hline $\begin{array}{l}\text { Intention-to-treat analysis } \\
\text { conducted }\end{array}$ & Low risk & $\begin{array}{l}\text { "all analyses were done on an intention-to-treat basis." } \\
\text { No reporting of how missing data handled. }\end{array}$ \\
\hline $\begin{array}{l}\text { Groups received same } \\
\text { treatment (apart from the } \\
\text { intervention) }\end{array}$ & Low risk & $\begin{array}{l}\text { "Patients from both groups received individualised medical treatment includ- } \\
\text { ing non-invasive and invasive cardiological procedures, surgical revascularisa- } \\
\text { tion, pharmacotherapy, and lifestyle counselling as determined by their usual } \\
\text { doctors. Access to community cardiac rehabilitation programs was limited for } \\
\text { the conventional management group." }\end{array}$ \\
\hline
\end{tabular}


Bäck 2008

Methods

Study design: Single centre RCT

Country: Sweden

Dates patients recruited: 2004 to 2006

Maximum follow up: 8 months (6 months following $\mathrm{PCl}$ )

Participants Inclusion criteria: Coronary artery stenosis documented by angiography or previous coronary artery bypass grafting, classes I-III angina pectoris, classified according to Canadian Cardiovascular Society.

Exclusion criteria: disabling disease that hindered regular exercise, or if the patient has already engaged in exercise more than 3 days/week.

N Randomised: total: 37; intervention: 21; comparator: 16

Diagnosis (\% of pts): stable CAD: $100 \%$

Age (years): 63.6 years; intervention: 61.5 (59.8 - 65.5) ; comparator: 64 (58.5 - 71.0)

Percentage male: $86.5 \%$. intervention: $81.0 \%$; comparator: $93.8 \%$

Ethnicity: NR

Interventions

Intervention: Patients were asked to exercise at home on a bicycle ergometer for $30 \mathrm{~min}$ (including a 10 min warm up and a 5 min cool down), 5 days a week for 8 months. The training programme was initiated 2 months before the $\mathrm{PCl}$. Twice a week the training patients were allowed to exchange cycling for an equivalent exercise such as jogging or swimming.

Components: exercise and education.

Setting: home.

Aerobic exercise:

Modality: bicycle ergometer.

Length of session: $30 \mathrm{~min}$.

Frequency: 5 times a week.

Intensity: $70 \%$ of $\mathrm{V}_{2}$ max.

Resistance training included? Resistance exercise with elastic bands, 3 times a week.

Total duration: 8 months.

Co-interventions: Patients in both groups were invited to participate in the CR care consisting of group-based lifestyle education and aerobic as well as resistance exercise twice a week during months 4 to 6.

Comparator: usual care.

Co-interventions: as above.

Outcomes $\quad \mathrm{PCl}$ at 2 months before $\mathrm{PCl}$ and 6 months after $\mathrm{PCl}$.

Source of funding The Swedish Heart Association, The Research and Development Council for Southern Gothenberg and
Bohuslan, and Rene Eanders Foundation.

Conflicts of interest

NR 
Bäck 2008 (Continued)

Notes

\section{Risk of bias}

\begin{tabular}{|c|c|c|}
\hline Bias & Authors' judgement & Support for judgement \\
\hline $\begin{array}{l}\text { Random sequence genera- } \\
\text { tion (selection bias) }\end{array}$ & Unclear risk & "randomised". \\
\hline $\begin{array}{l}\text { Allocation concealment } \\
\text { (selection bias) }\end{array}$ & Unclear risk & Not reported. \\
\hline $\begin{array}{l}\text { Blinding of outcome as- } \\
\text { sessment (detection bias) } \\
\text { All outcomes }\end{array}$ & Unclear risk & Blinding not described. \\
\hline $\begin{array}{l}\text { Incomplete outcome data } \\
\text { (attrition bias) } \\
\text { All outcomes }\end{array}$ & High risk & $8.1 \%$ lost to follow-up, no description of withdrawals or dropouts. \\
\hline $\begin{array}{l}\text { Selective reporting (re- } \\
\text { porting bias) }\end{array}$ & Low risk & $\begin{array}{l}\text { All outcomes reported at all time points (although absolute values not always } \\
\text { given). }\end{array}$ \\
\hline $\begin{array}{l}\text { Groups balanced at base- } \\
\text { line }\end{array}$ & High risk & $\begin{array}{l}\text { "There were no significant differences in baseline characteristics between the } \\
\text { training and control group, except for physical activity with the control group } \\
\text { being more physically active". }\end{array}$ \\
\hline $\begin{array}{l}\text { Intention-to-treat analysis } \\
\text { conducted }\end{array}$ & Low risk & Yes. \\
\hline $\begin{array}{l}\text { Groups received same } \\
\text { treatment (apart from the } \\
\text { intervention) }\end{array}$ & Low risk & $\begin{array}{l}\text { "patients were randomised,....to either training group or control group. All pa- } \\
\text { tients in the training group were asked to exercise......". }\end{array}$ \\
\hline
\end{tabular}

\section{Carlsson 1998}

Methods Study design: Single centre RCT

Country: Sweden

Dates patients recruited: NR

Maximum follow up: 1 year

Participants Inclusion criteria: $\mathrm{AMI}$; $\mathrm{CABG}<2$ weeks prior; $\mathrm{PCl}<2$ weeks prior.

Exclusion criteria: Signs of unstable angina; signs of ST-depression at exercise test of more than $3 \mathrm{~mm}$ in 2 chest leads or more than $2 \mathrm{~mm}$ in two limb leads at four weeks post-discharge from hospital, signs of CHF, severe, non-cardiac disease; drinking problems, not a Swedish speaker.

N Randomised: total: 235; intervention: 118; comparator: 117

Diagnosis (\% of pts):

CABG: $29 \%$

AMI: $21 \%$ 
Carlsson 1998 (Continued)

\author{
Age (mean $\pm S D)$ : \\ AMI patients: intervention: $62.2 \pm 5.8$; comparator: $61.7 \pm 6$ \\ CABG patients: intervention: $62.7 \pm 4.8$; comparator: $59.8 \pm 4.8$ \\ Percentage male: NR \\ Ethnicity: NR
}

Interventions

Intervention: Continuous physical exercise programme 2-3 times weekly for a period of 2-3 months. The exercise sessions lasted one hour and were comprised of the following parts: 10 minutes of warmup; 40 minutes of interval walking or jogging; 10 minute cool down period (consisting of relaxation and light stretching exercises). Individual exercise schedules were provided in order to maintain the effects of the exercise programme beyond the discharge from the hospital training centre.

Components: exercise plus education.

Setting: centre and then home.

\title{
Aerobic exercise:
}

Modality: walking or jogging.

Length of session: 60 minutes.

Frequency: 2-3 times/week.

Intensity: NR

Resistance training included? no.

Total duration: 2-3 months.

Co-interventions: 9 hours of nurse counselling in individual and group sessions over 1 year; smoking cessation 1.5 hours, dietary management 5.5 hours.

Comparator: Usual Care, which included two or three visits to their general practitioners during the first year.

Co-interventions: All patients were informed about CAD risk factors and the effect of lifestyle changes on the prognosis.

\begin{tabular}{ll}
\hline Outcomes & Mortality. \\
\hline Source of funding & NR \\
\hline Conflicts of interest & NR \\
\hline Notes & $\begin{array}{l}\text { Groups of 20 patients randomly allocated to intervention and control groups (usual care). Randomised } \\
\text { In first 3 weeks post discharge all participants had 2 visits by nurse \& } 1 \text { by cardiologist + all participants } \\
\text { invited to join regular exercise group x 1 per week for } 30 \text { mins information \& 30 mins easy interval train- } \\
\text { ing. }\end{array}$ \\
\hline Risk of bias & Authors' judgement Support for judgement \\
\hline Bias & Unclear risk $\quad$ Not reported. \\
\hline $\begin{array}{l}\text { Random sequence genera- } \\
\text { tion (selection bias) }\end{array}$ &
\end{tabular}


Carlsson 1998 (Continued)

Allocation concealment $\quad$ Unclear risk $\quad$ Not reported.
(selection bias)

Blinding of outcome as- Unclear risk Blinding not described.

sessment (detection bias)

All outcomes

\begin{tabular}{lll}
\hline $\begin{array}{l}\text { Incomplete outcome data } \\
\text { (attrition bias) } \\
\text { All outcomes }\end{array}$ & High risk & $<20 \%$ lost to follow up, no description of withdrawals or dropouts. \\
\hline $\begin{array}{l}\text { Selective reporting (re- } \\
\text { porting bias) }\end{array}$ & Low risk & All outcomes reported at all time points. \\
\hline $\begin{array}{l}\text { Groups balanced at base- } \\
\text { line }\end{array}$ & Unclear risk & Basline data not shown. \\
\hline $\begin{array}{l}\text { Intention-to-treat analysis } \\
\text { conducted }\end{array}$ & Low risk & Yes. \\
\hline $\begin{array}{l}\text { Groups received same } \\
\text { treatment (apart from the } \\
\text { intervention) }\end{array}$ & High risk & $\begin{array}{l}\text { "The intervention consisted of nurse counselling, dietary education and phys- } \\
\text { ical training........During the time from randomisation, three weeks after dis- } \\
\text { charge from hospital to three months later, the patients in the intervention } \\
\text { group participated in an education programme." }\end{array}$ \\
\hline
\end{tabular}

\section{Carson 1982}

Methods Study design: Single centre RCT; patients randomised 6 weeks post admission.

Country: UK

Dates patients recruited: NR (Recruited over a $31 / 2$ year period)

Maximum follow up: 3 years

Participants

Inclusion criteria: MI; diagnosis based on ECG changes and/or elevation of serum glutamic oxaloacetic transaminase or lactic dehydrogenase taken on three consecutive days.

Exclusion criteria: > 70 years; heart failure at follow-up clinic; cardio-thoracic ratio exceeding 59\%; severe chronic obstructive lung disease; hypertension requiring treatment; diabetes requiring insulin; disabling angina during convalescence; orthopaedic or medical disorders likely to impede progress in the gym, personality disorders likely to render patient unsuitable for the course.

N Randomised: total: 303; intervention: 151; comparator: 152

Diagnosis (\% of pts): MI: $100 \%$

Age (Mean \pm SE): intervention: $50.3 \pm 0.65$; comparator: $52.8 \pm 0.67$

Percentage male: intervention: $100 \%$; comparator: $100 \%$

Ethnicity: NR

Interventions

Intervention: Patients attended the hospital gym twice weekly for 12 weeks. They were supervised by a doctor and physical educationalist and full resuscitative equipment was available. The exercises were arranged on a circuit basis and pure isometric exercise was avoided.

Components: exercise only.

Setting: centre. 
Carson 1982 (Continued)

\section{Aerobic exercise:}

Modality: exercises arranged on a circuit basis.

Length of session: NR

Frequency: twice per week.

Intensity: NR

Resistance training included? No.

Total duration: 12 weeks.

Co-interventions: none described.

Comparator: did not attend gym.

Co-interventions: none described.

\begin{tabular}{ll}
\hline Outcomes & Total mortality, non fatal MI at 5 months, 1 year, 2 years and 3 years after MI (mean follow-up 2.1 years). \\
\hline Source of funding & Department for Health and Social Security Grant. \\
\hline Conflicts of interest & NR \\
\hline Notes & There appears to be a reduction in mortality in exercise participants with inferior MI.
\end{tabular}

\section{Risk of bias}

\begin{tabular}{|c|c|c|}
\hline Bias & Authors' judgement & Support for judgement \\
\hline $\begin{array}{l}\text { Random sequence genera- } \\
\text { tion (selection bias) }\end{array}$ & Unclear risk & "randomly allocated". \\
\hline $\begin{array}{l}\text { Allocation concealment } \\
\text { (selection bias) }\end{array}$ & Unclear risk & Not reported. \\
\hline $\begin{array}{l}\text { Blinding of outcome as- } \\
\text { sessment (detection bias) } \\
\text { All outcomes }\end{array}$ & Unclear risk & Blinding not described. \\
\hline $\begin{array}{l}\text { Incomplete outcome data } \\
\text { (attrition bias) } \\
\text { All outcomes }\end{array}$ & High risk & $21 \%$ lost to follow up, no description of withdrawals or dropouts. \\
\hline $\begin{array}{l}\text { Selective reporting (re- } \\
\text { porting bias) }\end{array}$ & Low risk & All outcomes were reported at all time points described in the methods. \\
\hline $\begin{array}{l}\text { Groups balanced at base- } \\
\text { line }\end{array}$ & High risk & $\begin{array}{l}\text { The mean age of the exercise group was } 50.3 \text { years and of the control group } 52 \\
\text { years; these values lie outside the } 95 \text { per cent confidence limits for the popula- } \\
\text { tion mean ( } 50.7 \text { to } 52.5) \text {. }\end{array}$ \\
\hline $\begin{array}{l}\text { Intention-to-treat analysis } \\
\text { conducted }\end{array}$ & High risk & No. \\
\hline $\begin{array}{l}\text { Groups received same } \\
\text { treatment (apart from the } \\
\text { intervention) }\end{array}$ & Low risk & "the exercise group attended the hospital gym twice weekly for 12 weeks." \\
\hline
\end{tabular}




\section{Dates patients recruited: NR}

Maximum follow up: 12 months

Participants Inclusion criteria: Men and women aged 70 years or younger who were hospitalised for AMI.

Exclusion criteria: none described.

N Randomised: total: 585; intervention: 293; comparator: 292

Diagnosis (\% of pts): MI: $100 \%$

Age (mean): intervention: $57 \pm 8$; comparator: $57 \pm 8$

Percentage male: intervention: $78.5 \%$; comparator: $79.1 \%$

Ethnicity (White, \%): intervention: $78.0 \%$; comparator: $75.9 \%$

Intervention: The exercise prescription was based on a heart rate range corresponding to $60 \%$ to $85 \%$ of the peak heart rate achieved during treadmill testing. Patients were instructed to exercise at the prescribed heart rate for 30 minutes per day 5 days per week. Patients walked briskly, jogged, rode a bicycle, or swam. After 4 weeks, the ceiling of the heart-rate training range was raised to $100 \%$ of the peak treadmill exercise heart rate or $85 \%$ of the age-predicted max HR.

Components: exercise plus education.

Setting: nurse-managed, home-based.

\section{Aerobic exercise:}

Modality: walking, jogging, cycling, or swimming.

Length of session: 30 minutes per day.

Frequency: 5 days per week.

Intensity: $60 \%$ to $85 \%$ of the peak heart rate achieved during treadmill testing, then raised to $100 \%$.

Resistance training included? No.

Total duration: 12 months.

Co-interventions: All medically eligible patients received exercise training; all smokers received the smoking cessation intervention; and all patients received dietary counselling and, if needed, lipid-lowering drug therapy.

Comparator: Usual care including physician counselling on smoking cessation, nutritionist counselling on dietary change during hospitalisation, and physician-managed, lipid-lowering drug therapy after hospital discharge.

Co-interventions: Group outpatient smoking cessation programmes were available for a $\$ 50$ fee. Group exercise rehabilitation, not generally provided, was available to patients at various community facilities at an average cost of $\$ 1800$ to $\$ 2700$ for 3 months' participation.

Outcomes Total mortality.


DeBusk 1994 (Continued)

Source of funding

Grant Support: By HL38874 from the National Heart, Lung, and Blood Institute, Bethesda, Maryland and a Shannon Award from the National Institutes of Health, Bethesda, Maryland. Dr. Thomas participated as a Clinical Scholar of the Robert Wood Johnson Foundation.

Conflicts of interest NR

Notes Levels of psychological distress dropped significantly for both groups by 12 months.

\section{Risk of bias}

\begin{tabular}{|c|c|c|}
\hline Bias & Authors' judgement & Support for judgement \\
\hline $\begin{array}{l}\text { Random sequence genera- } \\
\text { tion (selection bias) }\end{array}$ & Unclear risk & "randomly allocated". \\
\hline $\begin{array}{l}\text { Allocation concealment } \\
\text { (selection bias) }\end{array}$ & Unclear risk & Not reported. \\
\hline $\begin{array}{l}\text { Blinding of outcome as- } \\
\text { sessment (detection bias) } \\
\text { All outcomes }\end{array}$ & Unclear risk & Blinding not described. \\
\hline $\begin{array}{l}\text { Incomplete outcome data } \\
\text { (attrition bias) } \\
\text { All outcomes }\end{array}$ & High risk & $33 \%$ lost to follow up, no description of withdrawals \& dropouts. \\
\hline $\begin{array}{l}\text { Selective reporting (re- } \\
\text { porting bias) }\end{array}$ & Low risk & All outcomes reported for all time points described. \\
\hline $\begin{array}{l}\text { Groups balanced at base- } \\
\text { line }\end{array}$ & Low risk & $\begin{array}{l}\text { "No significant differences were noted between groups for any of the vari- } \\
\text { ables." }\end{array}$ \\
\hline $\begin{array}{l}\text { Intention-to-treat analysis } \\
\text { conducted }\end{array}$ & Low risk & $\begin{array}{l}\text { Yes - "Patients remained in their original groups throughout the study, and } \\
\text { analysis was based on intention to treat." }\end{array}$ \\
\hline $\begin{array}{l}\text { Groups received same } \\
\text { treatment (apart from the } \\
\text { intervention) }\end{array}$ & High risk & $\begin{array}{l}\text { "The behavioral interventions in our case-management system, were offered } \\
\text { to the } 293 \text { patients in the intervention group in addition to usual care...." } \\
\text { "All medically eligible patients received exercise training; all smokers received } \\
\text { the smoking cessation intervention; and all patients received dietary coun- } \\
\text { selling and, if needed, lipid-lowering drug therapy." }\end{array}$ \\
\hline
\end{tabular}

Dorn 1999

Methods See Shaw 1981 for study characteristics and risk of bias assessment

\section{Participants}

Interventions

\section{Outcomes}

\section{Source of funding}

Conflicts of interest 
Dorn 1999 (Continued)

Notes

Dugmore 1999

Methods

Study design: Single centre RCT

Country: UK

Dates patients recruited: between 1984 and 1988

Maximum follow up: 5 yrs

Participants

Inclusion criteria: MI according to conventional WHO cardiac enzyme and ECG criteria of MI.

Exclusion criteria: NR

N Randomised: total: 124; intervention: 62; comparator: 62

Diagnosis (\% of pts): MI: $100 \%$

Age (years): Intervention: 54.8; Comparator: 55.7

Percentage male: $98 \%$ intervention: NR; comparator: NR

Ethnicity: NR

Interventions

Intervention: Patients received regular aerobic and local muscular endurance training three times a week for 12 months. This consisted of warm up and cool down exercises, sit ups, wall bar/bench step ups, cycle ergometry, and a major component centred on the training of aerobic capacity, using walking and jogging. Training programmes were individually designed and based on the results of regular exercise tests and trial exercise prescriptions.

Components: exercise only.

Setting: centre.

\section{Aerobic exercise:}

Modality: walking, jogging and cycle ergometry.

Length of session: individually designed.

Frequency: 3 times a week.

Intensity: varied between approx 50-65\% of measured peak oxygen uptake $\left(\mathrm{VO}_{2}\right)$ in the poor prognosis patients and $65-80 \%$ of peak $\mathrm{VO}_{2}$ in those with a good prognosis.

Resistance training included? local muscular endurance training.

Total duration: 12 months.

Co-interventions: none described.

Comparator: received no formal exercise training throughout the same 12 month period.

Co-interventions: none described. 
Dugmore 1999 (Continued)

Conflicts of interest

NR

Notes

The population was subdivided into groups with good and bad prognosis. There were 36 patients with a good prognosis and 26 patients with a poor prognosis. Each group were matched with control patients.

\section{Risk of bias}

\begin{tabular}{|c|c|c|}
\hline Bias & Authors' judgement & Support for judgement \\
\hline $\begin{array}{l}\text { Random sequence genera- } \\
\text { tion (selection bias) }\end{array}$ & Unclear risk & "randomly allocated" \\
\hline $\begin{array}{l}\text { Allocation concealment } \\
\text { (selection bias) }\end{array}$ & Unclear risk & Not reported. \\
\hline $\begin{array}{l}\text { Blinding of outcome as- } \\
\text { sessment (detection bias) } \\
\text { All outcomes }\end{array}$ & Unclear risk & Blinding not described. \\
\hline $\begin{array}{l}\text { Incomplete outcome data } \\
\text { (attrition bias) } \\
\text { All outcomes }\end{array}$ & Low risk & All patients accounted for. \\
\hline $\begin{array}{l}\text { Selective reporting (re- } \\
\text { porting bias) }\end{array}$ & Low risk & All outcomes reported for all time points described. \\
\hline \multirow[t]{2}{*}{$\begin{array}{l}\text { Groups balanced at base- } \\
\text { line }\end{array}$} & Low risk & $\begin{array}{l}\text { Patients were classified and matched prior to randomisation "patients were } \\
\text { classified as having either a good or a poor prognosis on the basis of their ini- } \\
\text { tial responses to early exercise testing". }\end{array}$ \\
\hline & & Figures tabulated; no P values given, but all look very well matched. \\
\hline $\begin{array}{l}\text { Intention-to-treat analysis } \\
\text { conducted }\end{array}$ & Unclear risk & Unclear. \\
\hline $\begin{array}{l}\text { Groups received same } \\
\text { treatment (apart from the } \\
\text { intervention) }\end{array}$ & Low risk & $\begin{array}{l}\text { "62 patients were randomly allocated to a regular weekly aerobic training pro- } \\
\text { gramme, three times a week for } 12 \text { months, and compared with } 62 \text { matched } \\
\text { controls who did not receive any formal exercise training." }\end{array}$ \\
\hline
\end{tabular}

Engblom 1996

Study design: Single centre open RCT
Country: Finland
Dates patients recruited: February 1986 to December 1987
Maximum follow up: 5 years

\section{Participants}

Inclusion criteria: patients who underwent elective CABG.

Exclusion criteria: any other serious disease; $>65$ years of age.

N Randomised: total: 228; intervention: 119; comparator: 109

Diagnosis (\% of pts): 
Engblom 1996 (Continued)

Previous unstable angina: intervention: 29; comparator: 31

Previous MI: intervention: 42; comparator: 46

Hypertension: intervention: 31; comparator: 23

LVEF: intervention: 70.3; comparator: 71.4

Age (mean \pm SD): intervention: $54.1 \pm 5.9$; comparator: $54.3 \pm 6.2$

Percentage male: $88 \%$

Ethnicity: NR

Intervention: 6 to 8 weeks after the CABG, patients followed a 3 week general CR program, mainly based on exercises, including 24 hours of supervised activities consisting of ergometer cycle training, ball games, outdoor activities, gymnastics, and swimming. The patients were also advised to increase their physical activity in leisure time.

Components: exercise and education.

Setting: supervised group sessions at centre.

\section{Aerobic exercise:}

Modality: ergometer cycle training, ball games, outdoor activities, gymnastics, and swimming.

Length of session: NR

Frequency: NR

Intensity: NR

\section{Resistance training included? NR}

Total duration: 3 weeks (plus an additional 5 days over a 30 month period).

Co-interventions: Patients participated in a 4-stage CR programme over 30 months, including dietary counselling and advice about the importance of healthy nutrition and economical cooking.

Comparator: All of the patients in both groups received standard postoperative care which consisted of visits to the cardiac outpatient clinic 2, 6, 12, 24, 36, and 60 months after the CABG.

Co-interventions: none described.

\begin{tabular}{ll}
\hline Outcomes & Mortality, CABG, HRQL: Nottingham Health Profile. \\
\hline Source of funding & Grants from the Sauli Viikari Fund within the Cultural Foundation of Varsinais-Suomi, Turku, Finland. \\
\hline Conflicts of interest & NR \\
\hline Notes & $\begin{array}{l}\text { Five years after CABG only 20\% of participants were working, despite } 90 \% \text { of participants being in func- } \\
\text { tional classes 1-2. Almost half of participants had retired pre CABG. Many other factors affect return to } \\
\text { work post-CABG - age, education, physical requirements of the job, type of occupation, self employed } \\
\text { status, non work income, personality type, self perception of working capacity and mostly length of ab- } \\
\text { sence from work pre- CABG. }\end{array}$
\end{tabular}

\section{Risk of bias}

\begin{tabular}{lll}
\hline Bias & Authors' judgement & Support for judgement \\
\hline $\begin{array}{l}\text { Random sequence genera- } \\
\text { tion (selection bias) }\end{array}$ & Unclear risk & Not reported. \\
\hline
\end{tabular}


Engblom 1996 (Continued)

\begin{tabular}{l}
$\begin{array}{l}\text { Allocation concealment } \\
\text { (selection bias) }\end{array} \quad$ Unclear risk Not reported. \\
\hline
\end{tabular}

Blinding of outcome as- Unclear risk Blinding not described.

sessment (detection bias)

All outcomes

\begin{tabular}{|c|c|c|}
\hline $\begin{array}{l}\text { Incomplete outcome data } \\
\text { (attrition bias) } \\
\text { All outcomes }\end{array}$ & High risk & $13 \%$ lost to follow up, no description of withdrawals or dropouts. \\
\hline $\begin{array}{l}\text { Selective reporting (re- } \\
\text { porting bias) }\end{array}$ & Low risk & All outcomes were reported for all time points described. \\
\hline $\begin{array}{l}\text { Groups balanced at base- } \\
\text { line }\end{array}$ & Low risk & $\begin{array}{l}\text { "The baseline characteristics and surgical data for the patients were not statis- } \\
\text { tically significantly different between the rehabilitation and hospital groups". }\end{array}$ \\
\hline $\begin{array}{l}\text { Intention-to-treat analysis } \\
\text { conducted }\end{array}$ & Low risk & $\begin{array}{l}\text { "The few patients who did not participate in all rehabilitation courses were in- } \\
\text { cluded in the analyses". }\end{array}$ \\
\hline $\begin{array}{l}\text { Groups received same } \\
\text { treatment (apart from the } \\
\text { intervention) }\end{array}$ & Low risk & $\begin{array}{l}\text { "Consecutive patients....... were randomly allocated to receive standard care } \\
\text { plus rehabilitation (rehabilitation group, } \mathrm{n}=119) \text { or standard care alone". } \\
\text { "It followed a general cardiac rehabilitation program, mainly based on exercis- } \\
\text { es." }\end{array}$ \\
\hline
\end{tabular}

\section{Erdman 1986}

\begin{tabular}{ll} 
Methods & Study design: Single centre RCT \\
Country: Netherlands \\
Dates patients recruited: September 1976 to March 1978 \\
Maximum follow up: 5 years \\
\hline Participants & $\begin{array}{l}\text { Inclusion criteria: First MI within } 6 \text { months before the first psychological investigation; <65 years; meet } \\
\text { three psychological inclusion criteria - one or more symptoms of the anxiety reaction, diminished self- } \\
\text { esteem, positive motivation to take part in the programme. }\end{array}$
\end{tabular}

Exclusion criteria: Severe cardiomyopathy, severe valvular disorders, inadequate performance on exercise, unstable angina pectoris.

N Randomised: total: 80; intervention: 40; comparator: 40

Diagnosis (\% of pts): MI: $100 \%$

Age (years): 51 years (range 35-60 years); intervention: NR; comparator: NR

Percentage male: intervention: 100\%; comparator: $100 \%$

Ethnicity: NR

Interventions

Intervention: Two $1 \frac{1 / 2}{2}$ hour sessions of fitness training a week in a conventional gymnasium, supervised by a cardiologist. Each session consisted of a 15 min warm up, gymnastics and jogging (both 15 $\mathrm{min}$ ); sport such as volleyball, soccer and hockey (30 $\mathrm{min}$ ) and relation exercises (15 min).

Components: exercise and education.

Setting: supervised group sessions in centre. 


\section{Aerobic exercise:}

Modality: gymnastics, jogging and team sports.

Length of session: $90 \mathrm{~min}$.

Frequency: twice a week.

Intensity: NR

Resistance training included? No.

Total duration: 6 months.

Co-interventions: in cases of severe psychopathology, a psychologist or a psychiatrist was consulted.

Comparator: Home rehabilitation- patients received an educational brochure with guidelines and advice about physical fitness training and jogging.

Co-interventions: Treatment with either beta blockers or anticoagulants was given upon indication only and not as a prophylactic measure.

\begin{tabular}{ll}
\hline Outcomes & Mortality, non fatal MI at 5 years. \\
\hline Source of funding & Dutch Heart Foundation. \\
\hline Conflicts of interest & NR \\
\hline Notes & $\begin{array}{l}\text { Complex presentation of results. } \\
\text { Authors conclude that patients who will benefit from rehab can be detected on psychological grounds. } \\
\text { Those who have engaged in habitual exercise, but feel seriously disabled, yet do not inhibited in a } \\
\text { group will benefit from rehab. }\end{array}$ \\
\hline
\end{tabular}

\section{Risk of bias}

\begin{tabular}{lll}
\hline Bias & Authors' judgement & Support for judgement \\
\hline $\begin{array}{l}\text { Random sequence genera- } \\
\text { tion (selection bias) }\end{array}$ & Low risk & "randomly allocated by means of a table for random numbers". \\
\hline $\begin{array}{l}\text { Allocation concealment } \\
\text { (selection bias) }\end{array}$ & Unclear risk & Not reported. \\
\hline $\begin{array}{l}\text { Blinding of outcome as- } \\
\text { sessment (detection bias) } \\
\text { All outcomes }\end{array}$ & Unclear risk & Blinding not described. \\
\hline $\begin{array}{l}\text { Incomplete outcome data } \\
\text { (attrition bias) }\end{array}$ & High risk & $29 \%$ lost to follow up, no description of withdrawals or dropouts. \\
$\begin{array}{l}\text { All outcomes } \\
\begin{array}{l}\text { Selective reporting (re- } \\
\text { porting bias) }\end{array}\end{array}$ & Low risk & All outcomes were reported at all time points. \\
\hline $\begin{array}{l}\text { Groups balanced at base- } \\
\text { line }\end{array}$ & Low risk & “There were no differences between the study groups in terms of prior stress- \\
\hline $\begin{array}{l}\text { Intention-to-treat analysis } \\
\text { conducted }\end{array}$ & High risk & ful life-events". No other baseline measures are reported. \\
\hline
\end{tabular}


Erdman 1986 (Continued)

Groups received same treatment (apart from the intervention)
Low risk

"The rehab program consists of two $1 \frac{1}{2}$ hour sessions of fitness training a week in a conventional gym, supervised by a cardiologist. The multidisciplinary team is composed of two physiotherapists, a social worker and a nurse. In cases of severe psychopathology, a psychologist or a psychiatrist was consulted...".

"Both groups received the usual outpatient cardiologic care."

\section{Fletcher 1994}

\section{Methods}

Study design: Single centre RCT

Country: US

Dates patients recruited: NR

Maximum follow up: 6 months.
Inclusion criteria: $\leq 73$ years; CAD and physical disability. CAD documented by history of MI, coronary artery bypass surgery, $\mathrm{PCl}$ or angiographically demonstrated $\mathrm{CAD}$; have the functional use of more than 2 extremities, 1 being an arm, in order to perform the exercise test and training protocols.

Exclusion criteria: Uncontrolled hypertension or diabetes mellitus, clinically significant cardiac dysrhythmias, unstable angina pectoris, cognitive deficits, or other problems that would interfere with compliance to the prescribed exercise and diet protocol.

N Randomised: total: 88; intervention: 41; comparator: 47

Diagnosis (\% of pts): CAD and a physical disability

Age (mean \pm SD): intervention: $62 \pm 8$; comparator: $63 \pm 7$

Percentage male: intervention: 100\%; comparator: 100\% Ethnicity: NR

Interventions

Intervention: Participants were provided with a wheelchair ramp with rollers and a telephone electrocardiographic recording device. They were instructed to exercise using the ramp which essentially transformed their wheelchair into a stationary wheelchair ergometer. Specific instructions were to exercise 5 days/week for 20 minutes a day for a total of 100 minutes each week.

Components: exercise plus education.

Setting: home.

\section{Aerobic exercise:}

Modality: stationary wheelchair ergometer.

Length of session: $20 \mathrm{~min}$.

Frequency: 5 days/week.

Intensity: $85 \%$ of predicted maximal heart rate.

Resistance training included? no.

Total duration: 6 months.

Co-interventions: Both groups received didactic and written dietary instruction from a registered dietitian on the American Heart Association Step I low-cholesterol, low-saturated fat diet.

Comparator: usual care. 
Fletcher 1994 (Continued)

Co-interventions: Participants in the control group received dietary instruction and were instructed to follow activity guidelines provided by their primary physician and health care team.

\begin{tabular}{|c|c|c|}
\hline Outcomes & \multicolumn{2}{|c|}{ Total mortality, non fatal MI at 6 months. } \\
\hline Source of funding & \multicolumn{2}{|c|}{ United States Department of Education. } \\
\hline Conflicts of interest & \multicolumn{2}{|l|}{ NR } \\
\hline Notes & \multicolumn{2}{|c|}{ The treatment programme decreased myocardial oxygen demand. } \\
\hline \multicolumn{3}{|l|}{ Risk of bias } \\
\hline Bias & Authors' judgement & Support for judgement \\
\hline $\begin{array}{l}\text { Random sequence genera- } \\
\text { tion (selection bias) }\end{array}$ & Unclear risk & "randomized" \\
\hline $\begin{array}{l}\text { Allocation concealment } \\
\text { (selection bias) }\end{array}$ & Unclear risk & Not reported. \\
\hline $\begin{array}{l}\text { Blinding of outcome as- } \\
\text { sessment (detection bias) } \\
\text { All outcomes }\end{array}$ & Low risk & $\begin{array}{l}\text { "The same experienced cardiologist interpreted all echocardiograms and was } \\
\text { unaware of randomization procedures". }\end{array}$ \\
\hline $\begin{array}{l}\text { Incomplete outcome data } \\
\text { (attrition bias) } \\
\text { All outcomes }\end{array}$ & High risk & $32 \%$ lost to follow up, no description of withdrawals or dropouts. \\
\hline $\begin{array}{l}\text { Selective reporting (re- } \\
\text { porting bias) }\end{array}$ & Low risk & All outcomes reported for all time points. \\
\hline $\begin{array}{l}\text { Groups balanced at base- } \\
\text { line }\end{array}$ & High risk & $\begin{array}{l}\text { "Despite randomization procedures, the treatment group was further from } \\
\text { their physical disability event than the control Group". }\end{array}$ \\
\hline $\begin{array}{l}\text { Intention-to-treat analysis } \\
\text { conducted }\end{array}$ & Low risk & Yes \\
\hline $\begin{array}{l}\text { Groups received same } \\
\text { treatment (apart from the } \\
\text { intervention) }\end{array}$ & Low risk & $\begin{array}{l}\text { "Eighty eight men ...... were randomized to either a } 6 \text { month home exercise } \\
\text { training program using wheelchair ergometry or to a control group that re- } \\
\text { ceived usual and customary care....Both groups received dietary instructions } \\
\text { and were requested to follow a fat-controlled diet." }\end{array}$ \\
\hline
\end{tabular}

\section{Fridlund 1991}

\begin{tabular}{ll}
\hline Methods & Study design: Single centre RCT \\
Country: Sweden \\
Dates patients recruited: September 1985 to March 1988 \\
Maximum follow up: 5 years. \\
\hline Participants & $\begin{array}{l}\text { Inclusion criteria: } 65 \text { years or younger at the time of Ml; independent living in the Health Care District } \\
\text { after discharge from hospital; meaningful communication and rehabilitation that was not hindered by } \\
\text { the Ml or other serious illness. }\end{array}$
\end{tabular}


Exclusion criteria: cerebral or cardiac disorders or serious alcohol abuse.

N Randomised: total: 178; intervention:87 comparator: 91

Diagnosis (\% of pts):

MI: $100 \%$

Angina: intervention: $32.1 \%$; comparator: $33.3 \%$

Age (years): intervention: 55; comparator: 57.6

Percentage male: $87 \%$ intervention: $86.8 \%$; comparator: $87.3 \%$

Ethnicity: NR

Interventions

Intervention: Patients and their spouses visited the hospital for a 2 hour group session each week for 6 months. These group sessions consisted of a physical and a psychosocial part and were carried out together with a support team consisting of a physiotherapist, a physician and a rehabilitation nurse. The physical part consisted of both exercise and relaxation.

Components: exercise plus psychosocial support.

Setting: centre.

\section{Aerobic exercise:}

Modality: NR

Length of session: $2 \mathrm{hrs}$.

Frequency: once a week.

Intensity: NR

\section{Resistance training included? NR}

Total duration: 6 months.

Co-interventions: The psychosocial part contained eleven themes concerning lifestyle and risks after $\mathrm{MI}$ and psychosocial consequences of MI.

Comparator: routine cardiac follow-up.

Co-interventions: none described.

\begin{tabular}{ll}
\hline Outcomes & Total mortality, non fatal MI, revascularisations. \\
\hline Source of funding & $\begin{array}{l}\text { Swedish Heart Lung Foundation, National Association for Heart and Lung Patients, Sweden, and the } \\
\text { County Council, Halland, Sweden. }\end{array}$ \\
\hline Conflicts of interest & NR \\
\hline Notes & $\begin{array}{l}\text { Positive long-term effects on physical condition, life habits, cardiac health knowledge. No effects found } \\
\text { for cardiac events or psychological condition. }\end{array}$ \\
\hline Risk of bias & Authors' judgement Support for judgement \\
\hline Bias & Unclear risk "randomly subdivided" \\
\hline $\begin{array}{l}\text { Random sequence genera- } \\
\text { tion (selection bias) }\end{array}$ & \\
\hline
\end{tabular}


Fridlund 1991 (Continued)

$\begin{aligned} & \text { Allocation concealment } \\ & \text { (selection bias) }\end{aligned}$ Unclear risk Not reported.

\begin{tabular}{|c|c|c|}
\hline $\begin{array}{l}\text { Blinding of outcome as- } \\
\text { sessment (detection bias) } \\
\text { All outcomes }\end{array}$ & Unclear risk & Blinding not described. \\
\hline $\begin{array}{l}\text { Incomplete outcome data } \\
\text { (attrition bias) } \\
\text { All outcomes }\end{array}$ & High risk & $32 \%$ lost to follow up, no description of withdrawals or dropouts. \\
\hline $\begin{array}{l}\text { Selective reporting (re- } \\
\text { porting bias) }\end{array}$ & Low risk & $\begin{array}{l}\text { All outcomes reported at all time points (although absolute values not always } \\
\text { given). }\end{array}$ \\
\hline $\begin{array}{l}\text { Groups balanced at base- } \\
\text { line }\end{array}$ & Low risk & $\begin{array}{l}\text { "All differences are non-significant according to the chi-square test and /or } \\
\text { ANOVA test". }\end{array}$ \\
\hline $\begin{array}{l}\text { Intention-to-treat analysis } \\
\text { conducted }\end{array}$ & Low risk & Yes. \\
\hline $\begin{array}{l}\text { Groups received same } \\
\text { treatment (apart from the } \\
\text { intervention) }\end{array}$ & High risk & $\begin{array}{l}\text { "The rehabilitation programme involved two intervention strategies as its } \\
\text { main objective (a) lifestyle and life stress orientated and (b) social support ori- } \\
\text { ented.....group sessions consisted of a physical and a psychosocial part and } \\
\text { were carried out together with a support team..." }\end{array}$ \\
\hline
\end{tabular}

Giallauria 2008

\begin{tabular}{ll} 
Study design: Single centre RCT \\
Country: Italy \\
Dates patients recruited: NR \\
Maximum follow up: 6 months \\
\hline
\end{tabular}

Participants Inclusion criteria: acute ST elevation MI.

Exclusion criteria: residual myocardial ischemia, severe ventricular arrhythmias, AV block, valvular disease requiring surgery, pericarditis, severe renal dysfunction (creatinine $>2.5 \mathrm{mg} / \mathrm{dL}$ ).

N Randomised: total: 61; intervention: 30; comparator: 31

Diagnosis (\% of pts): MI: $100 \%$

Age (mean \pm SD): intervention: $55.9 \pm 3.1$; comparator: $55.1 \pm 3.7$

Percentage male: intervention: $73 \%$; comparator: $71 \%$

Ethnicity NR

Interventions

Intervention: Training sessions were supervised under continuous eletrocardiography monitoring. Each session was preceeded by a $5 \mathrm{~min}$ warm up and followed by a $5 \mathrm{~min}$ cool down. Exercise was performed for $30 \mathrm{~min}$ on a bicycle ergometer with the target of $60 \%$ to $70 \%$ of $\mathrm{VO}_{2}$ peak achieved at the initial symptom-limited cardiopulmonary exercise test. Exercise workload was gradually increased until the achievement of the predefined target.

Components: exercise only.

Setting: supervised in centre. 
Giallauria 2008 (Continued)

\section{Aerobic exercise:}

Modality: bicycle ergometer.

Length of session: $40 \mathrm{~min}$.

Frequency: 3 times a week.

Intensity: Target of $60-70 \%$ of $\mathrm{VO}_{2}$ peak achieved at the initial symptom-limited cardiopulmonary exercise test.

\section{Resistance training included? no.}

Total duration: 6 months.

Co-interventions: none described.

Comparator: Discharged with generic instructions on maintaining physical activity and a correct lifestyle.

Co-interventions: none described.

\begin{tabular}{ll}
\hline Outcomes & Fatal/non-fatal MI (6 month follow-up). \\
\hline Source of funding & "None" \\
\hline Conflicts of interest & "None" \\
\hline
\end{tabular}

Notes

\section{Risk of bias}

\begin{tabular}{|c|c|c|}
\hline Bias & Authors' judgement & Support for judgement \\
\hline $\begin{array}{l}\text { Random sequence genera- } \\
\text { tion (selection bias) }\end{array}$ & Unclear risk & "randomized" \\
\hline $\begin{array}{l}\text { Allocation concealment } \\
\text { (selection bias) }\end{array}$ & Unclear risk & Not reported \\
\hline $\begin{array}{l}\text { Blinding of outcome as- } \\
\text { sessment (detection bias) } \\
\text { All outcomes }\end{array}$ & Low risk & $\begin{array}{l}\text { "The physician performing all Doppler-echocardioraphy studies was.....blinded } \\
\text { to the patient allocation into the study protocol." }\end{array}$ \\
\hline $\begin{array}{l}\text { Incomplete outcome data } \\
\text { (attrition bias) } \\
\text { All outcomes }\end{array}$ & Low risk & All patients were accounted for. \\
\hline $\begin{array}{l}\text { Selective reporting (re- } \\
\text { porting bias) }\end{array}$ & Low risk & All outcomes were reported at all time points. \\
\hline $\begin{array}{l}\text { Groups balanced at base- } \\
\text { line }\end{array}$ & Low risk & $\begin{array}{l}\text { "no significant differences were observed between the two groups in baseline } \\
\text { cardiopulmonary parameters" }\end{array}$ \\
\hline $\begin{array}{l}\text { Intention-to-treat analysis } \\
\text { conducted }\end{array}$ & High risk & No. \\
\hline $\begin{array}{l}\text { Groups received same } \\
\text { treatment (apart from the } \\
\text { intervention) }\end{array}$ & Low risk & $\begin{array}{l}\text { "Group T patients were enrolled in a } 6 \text { month exercise-based cardiac rehabili- } \\
\text { tation programme whereas group C patients were discharged with generic in- } \\
\text { structions on maintaining physical activity and a correct lifestyle". }\end{array}$ \\
\hline
\end{tabular}


Maximum follow up: 1 year

Participants

Inclusion criteria: Angina pectoris according to Canadian Cardiovascular Society class I-III, with documented myocardial ischemia during stress-electrocardiogram and/or $99 \mathrm{mTc}$ scintigraphy and amenable to $\mathrm{PCl}$. Only patients living within a $25-\mathrm{km}$ radius of the host institution were recruited.

Exclusion criteria: Acute coronary syndromes or recent myocardial infarction ( $<2$ months); left main coronary artery stenosis $>25 \%$; reduced left ventricular function (ejection fraction $<40 \%$ ); significant valvular heart disease; insulin-dependent diabetes mellitus; previous coronary artery bypass graft or $\mathrm{PCl}$; and conditions excluding regular exercise.

N Randomised: total: 101; intervention: 51; comparator: 50

\section{Diagnosis ( $\%$ of pts):}

Stable CAD: $100 \%$

(class I to III angina pectoris)

Age (years \pm SEM): intervention: $62 \pm 1$; comparator: $60 \pm 1$

Percentage male: intervention: $100 \%$; comparator: $100 \%$ Ethnicity: NR

Intervention: During the first 2 weeks, patients exercised in the hospital 6 times/day for 10 min on a bicycle ergometer at $70 \%$ of the symptom-limited max HR. Before discharge, a maximal symptom-limited ergospirometry was performed to calculate the target heart rate for home training, which was defined as $70 \%$ of the maximal heart rate during symptom-limited exercise. Patients were asked to exercise on their bicycle ergometer close to the target heart rate for $20 \mathrm{~min}$ per day and to participate in one $60 \mathrm{~min}$ group training session of aerobic exercise/week.

Components: exercise only.

Setting: supervised exercise in hospital, followed by unsupervised at home plus weekly group training.

\section{Aerobic exercise:}

Modality: bicycle ergometer.

Length of session: 10 minutes.

Frequency: 6 times a day.

Intensity: $70 \%$ of symptom-limited max heart rate.

\section{Resistance training included? No.}

Total duration: 2 weeks, followed by 20 min per day unsupervised at $70 \%$ plus 60 min aerobic group training per week.

Co-interventions: All patients were recommended to receive acetylsalicyl acid, $\beta$-blockers, angiotensin-converting enzyme inhibitors and statins according to common guidelines.

Comparator: stent angioplasty: "the target lesion was treated with PCl after a bolus of 10,000 IU of heparin with a $6 \mathrm{~F}$ guiding catheter." 
Hambrecht 2004 (Continued)

Co-interventions: All patients were given acetylsalicylic acid $100 \mathrm{mg} / \mathrm{d}$ and clopidogrel $300 \mathrm{mg} / \mathrm{d}$ on the day before the procedure.

\begin{tabular}{ll}
\hline Outcomes & $\begin{array}{l}\text { Clinical symptoms, angina-free exercise capacity, myocardial perfusion, cost-effectiveness, and fre- } \\
\text { quency of a combined clinical end point (death of cardiac cause, stroke, CABG, angioplasty, acute my- } \\
\text { ocardial infarction, and worsening angina with objective evidence resulting in hospitalization). }\end{array}$ \\
\hline Source of funding & "This study was supported by an unconditional scientific grant from Aventis Germany". \\
\hline Conflicts of interest & NR \\
\hline Notes & 2 year results of this study are reported by Walther 2008. \\
\hline
\end{tabular}

\section{Risk of bias}

\begin{tabular}{|c|c|c|}
\hline Bias & Authors' judgement & Support for judgement \\
\hline $\begin{array}{l}\text { Random sequence genera- } \\
\text { tion (selection bias) }\end{array}$ & Low risk & $\begin{array}{l}\text { "Patients were randomly assigned to either stent angioplasty or exercise train- } \\
\text { ing by drawing an envelope with the treatment assignment enclosed." }\end{array}$ \\
\hline $\begin{array}{l}\text { Allocation concealment } \\
\text { (selection bias) }\end{array}$ & Unclear risk & Allocation concealment not described. \\
\hline $\begin{array}{l}\text { Blinding of outcome as- } \\
\text { sessment (detection bias) } \\
\text { All outcomes }\end{array}$ & Low risk & $\begin{array}{l}\text { "Initially and after } 12 \text { months the angina pectoris status of all patients was } \\
\text { classified according to CCS class by a physician blinded for patient assign- } \\
\text { ment." }\end{array}$ \\
\hline $\begin{array}{l}\text { Incomplete outcome data } \\
\text { (attrition bias) } \\
\text { All outcomes }\end{array}$ & Low risk & $\begin{array}{l}\text { Discontinued study, } \mathrm{n} \text { : intervention } 2 / 51 \text {; comparator } 2 / 50 \\
\text { Disabling stroke, } \mathrm{n} \text { : intervention } 1 / 51 \text {; comparator } 1 / 50 \\
\text { Refused angiography, n: intervention } 1 / 51 \text {; comparator } 0 / 50\end{array}$ \\
\hline $\begin{array}{l}\text { Selective reporting (re- } \\
\text { porting bias) }\end{array}$ & Low risk & All outcomes reported. \\
\hline $\begin{array}{l}\text { Groups balanced at base- } \\
\text { line }\end{array}$ & Low risk & $\begin{array}{l}\text { "Both groups were comparable with regard to baseline characteristics and } \\
\text { medical therapy (Table 1)." }\end{array}$ \\
\hline $\begin{array}{l}\text { Intention-to-treat analysis } \\
\text { conducted }\end{array}$ & Low risk & $\begin{array}{l}\text { "Follow-up began after randomization on an intention-to-treat basis." } \\
\text { "All dropout patients were followed up on an intention-to-treat basis for clini- } \\
\text { cal events and were contacted by phone." }\end{array}$ \\
\hline $\begin{array}{l}\text { Groups received same } \\
\text { treatment (apart from the } \\
\text { intervention) }\end{array}$ & Low risk & $\begin{array}{l}\text { "Medical treatment was adjusted according to current clinical guidelines and } \\
\text { was continued by the patients' private physicians..." }\end{array}$ \\
\hline
\end{tabular}

$\begin{array}{ll}\text { Methods } & \text { Study design: Multicentre RCT (4 sites) } \\ \text { Country: USA } \\ \text { Dates patients recruited: February } 1984 \text { to March } 1987 \\ \text { Maximum follow up: } 4 \text { years }\end{array}$


Haskell 1994 (Continued)

Participants
Inclusion criteria: Men and women < 75 years of age with clinically indicated coronary arteriography who lived within a 5-hour drive of Stanford University and considered capable of following the study protocol. After arteriography, patients received $\mathrm{PCI}$ or CABG and remained eligible if at least one major coronary artery had a segment with lumen narrowing between $5 \%$ and $69 \%$ that was unaffected by revascularisation procedures.

Exclusion criteria: Severe congestive heart failure, pulmonary disease, intermittent claudication, or noncardiac life-threatening illnesses; no qualifying segments, medical complication occurred during angiography, left ventricular ejection fraction of less than $20 \%$, or patient was in another research study.

N Randomised: total: 300; intervention: 145; comparator: 155

Diagnosis (\% of pts): CHD: $100 \%$

Age (mean \pm SD): intervention: $58.3 \pm 9.2$; comparator: $56.2 \pm 8.2$

Percentage male: $86 \%$

Ethnicity: NR
Intervention: A physical activity programme consisting of an increase in daily activities such as walking, climbing stairs, and household chores and a specific endurance exercise training programme* with the exercise intensity based on the subject's treadmill exercise test performance.

Components: exercise plus education.

Setting: home.

\section{Aerobic exercise:}

Modality: stationary cycling or walking.

Length of session: 30 min.

Frequency: 5 days a week.

Intensity: $70 \%$ to $85 \%$ of the peak heart rate attained on exercise testing at 3 weeks, an average of 96 to 121 beats/min.

\section{Resistance training included? no.}

\section{Total duration: NR}

Co-interventions: Each risk-reduction subject met with a nurse to design an individualised risk-reduction programme based on the subject's risk profile, his or her motivation, and resources for making specific changes. Patients were instructed by a dietitian in a low-fat, low-cholesterol, and high-carbohydrate diet with a goal of $<20 \%$ of energy intake from fat, $<6 \%$ from saturated fat, and $<75 \mathrm{mg}$ of cholesterol per day. Current or recent ex-smokers were provided with an individualised stop-smoking or relapse-prevention programme by a staff psychologist.

Comparator: usual care.

Co-interventions: none described.

Total \& CHD mortality, non fatal MI, revascularisation at yr 1, 2, 3 and 4.

\section{Source of funding} National Heart, Lung, and Blood Institute and a gift from the Claude R. Lambe Charitable Foundation. Lipid

drugs for patients in the risk reduction group provided by The Upjohn Company, Merck \& Company, and Parke-Davis, Inc. 
Haskell 1994 (Continued)

Notes
*This exercise programme followed guidelines developed previously for home-based exercise training of cardiac patients (Miller 1984).

The rate of change in the minimal coronary artery diameter was $47 \%$ less in I than $\mathrm{C}$. This was still significant when adjusted for age and baseline segment diameter $(P=0.03)$.

\section{Risk of bias}

\begin{tabular}{|c|c|c|}
\hline Bias & Authors' judgement & Support for judgement \\
\hline $\begin{array}{l}\text { Random sequence genera- } \\
\text { tion (selection bias) }\end{array}$ & Low risk & "Randomization was performed using a random-numbers table." \\
\hline $\begin{array}{l}\text { Allocation concealment } \\
\text { (selection bias) }\end{array}$ & Low risk & $\begin{array}{l}\text { "....sequentially numbered, sealed opaque envelopes for each stratification } \\
\text { category that were provided by the biostatistician". }\end{array}$ \\
\hline $\begin{array}{l}\text { Blinding of outcome as- } \\
\text { sessment (detection bias) } \\
\text { All outcomes }\end{array}$ & High risk & $\begin{array}{l}\text { "The staff collecting data in the clinic were not blinded to group assignment of } \\
\text { subjects". }\end{array}$ \\
\hline $\begin{array}{l}\text { Incomplete outcome data } \\
\text { (attrition bias) } \\
\text { All outcomes }\end{array}$ & High risk & $18 \%$ lost to follow up, no description of withdrawals or dropouts. \\
\hline $\begin{array}{l}\text { Selective reporting (re- } \\
\text { porting bias) }\end{array}$ & Low risk & All outcomes reported at all time points. \\
\hline $\begin{array}{l}\text { Groups balanced at base- } \\
\text { line }\end{array}$ & High risk & $\begin{array}{l}\text { "Significant differences between the usual-care and risk-reduction groups in- } \\
\text { clude body weight and HDL-C" }\end{array}$ \\
\hline $\begin{array}{l}\text { Intention-to-treat analysis } \\
\text { conducted }\end{array}$ & High risk & No. \\
\hline $\begin{array}{l}\text { Groups received same } \\
\text { treatment (apart from the } \\
\text { intervention) }\end{array}$ & High risk & $\begin{array}{l}\text { "After baseline evaluations, subjects were randomized to the usual care of } \\
\text { their own physician or to an individualized, multifactor, risk-reduction pro- } \\
\text { gram managed by the SCRIP staff in cooperation with the patient's personal } \\
\text { physician" }\end{array}$ \\
\hline & & $\begin{array}{l}\text { "Patients assigned to risk reduction were provided individualized programs in- } \\
\text { volving a low-fat and -cholesterol diet, exercise, weight loss, smoking cessa- } \\
\text { tion, and medications to favourably alter lipoprotein profiles." }\end{array}$ \\
\hline
\end{tabular}

Heller 1993

Study design: Cluster randomised multicentre RCT
Country: Australia
Dates patients recruited: 18 September 1990 to 5 December 1991
Maximum follow up: 6 months
Inclusion criteria: < 70 years with a suspected heart attack registered by the Newcastle collaborating
centre of the WHO MONICA Project and discharged alive from hospital.
$\begin{aligned} & \text { Exclusion criteria: Renal failure or other special dietary requirements and those considered by their } \\ & \text { physicians to have 'endstage' heart disease. }\end{aligned}$


Diagnosis ( $\%$ of pts): MI: $100 \%$

Age (mean \pm SD): intervention: $59 \pm 8$; comparator: $58 \pm 8$

Percentage male: $71 \%$

Ethnicity: NR

Interventions

Intervention: A mail-out programme designed to help patients reduce dietary fat, obtain regular exercise by walking and to quit smoking.

- 1st package: Step 1 "Facts on fat" kit, together with walking programmme information, encouragement to walk in the form of a magnetic reminder sticker, and "Quit for Life" programme for smokers.

- 2nd package: Steps 2-3 "Facts on fat" kit; exercise log.

- 3rd package: Steps 4-5 "Facts on fat" kit, together with information regarding local "Walking for Pleasure" groups.

Components: exercise plus education.

Setting: home.

\section{Aerobic exercise:}

Modality: walking.

Length of session: NR

Frequency: NR

Intensity: NR

\section{Resistance training included? NR}

Total duration: 6 months.

Co-interventions: Supplementary telephone contact was also used and a letter was sent to the family doctor regarding the benefit of aspirin and $\beta$ blockers for secondary prevention.

Comparator: usual care.

Co-interventions: none described.

\section{Outcomes}

Total mortality, HRQL.

Study outcomes assessed at 6 months.

\begin{tabular}{|c|c|c|}
\hline Source of funding & \multicolumn{2}{|c|}{ National Health and Medical Research Council of Australia. } \\
\hline Conflicts of interest & \multicolumn{2}{|l|}{ NR } \\
\hline Notes & \multicolumn{2}{|c|}{$\begin{array}{l}\text { Low use of preventative services (dietary, anti smoking) by both groups. } \\
10 \% \text { of patients received CR - mostly having had CABG. }\end{array}$} \\
\hline \multicolumn{3}{|l|}{ Risk of bias } \\
\hline Bias & Authors' judgement & Support for judgement \\
\hline $\begin{array}{l}\text { Random sequence genera- } \\
\text { tion (selection bias) }\end{array}$ & Unclear risk & $\begin{array}{l}\text { Cluster randomisation by GP. "All general practices were randomly allocated to } \\
\text { intervention or usual care within those strata." Method of randomisation not } \\
\text { described. }\end{array}$ \\
\hline
\end{tabular}


Heller 1993 (Continued)

$\begin{aligned} & \text { Allocation concealment } \\ & \text { (selection bias) }\end{aligned}$
Unclear risk

Blinding of outcome as- Unclear risk Blinding not described.

sessment (detection bias)

All outcomes

Incomplete outcome data High risk $\quad 17 \%$ lost to follow up, no description of withdrawals or dropouts.
(attrition bias)

All outcomes

Selective reporting (re- Low risk $\quad$ All outcomes reported at all time points.

porting bias)

\begin{tabular}{lll}
\hline $\begin{array}{l}\text { Groups balanced at base- } \\
\text { line }\end{array}$ & Low risk & $\begin{array}{l}\text { There were no significant differences in demographic characteristics, medical } \\
\text { history or patterns of consumption of tobacco, alcohol and fat. }\end{array}$ \\
\hline $\begin{array}{l}\text { Intention-to-treat analysis } \\
\text { conducted }\end{array}$ & Low risk & Yes. \\
\hline $\begin{array}{l}\text { Groups received same } \\
\begin{array}{l}\text { treatment (apart from the } \\
\text { intervention) }\end{array}\end{array}$ & High risk & $\begin{array}{l}\text { "A low-cost mail-out program was designed to help patients reduce dietary } \\
\text { fat, obtain regular exercise by walking and (for smokers only) to quit smoking. } \\
\text { Supplementary telephone contact was also used." }\end{array}$ \\
\hline
\end{tabular}

Higgins 2001

Methods

Study design: Single centre RCT

Country: Australia

Dates patients recruited: June 1995 to January 1997

Maximum follow up: Mean $=51$ weeks; range $=36$ to 56 weeks post $\mathrm{PCI}$

Participants Inclusion criteria: Patients scheduled for PCI.

Exclusion criteria: Major co-morbidity such as malignancy, a history of cerebrovascular accident, or other severe, chronic debilitating disease; previous CABG or peri-PCI complications; unemployment in previous year; MI within 1 month pre-procedure; surgical management at home time during the 1 year duration of study.

N Randomised: total: 105; intervention: 54; comparator: 51

Diagnosis (\% of pts):

Previous MI: intervention: 52\%; comparator: 51\%

Previous PCI: intervention: 10\%; comparator: 16\%

Age (years): intervention: 48 (range 31 to 63 ); comparator: 47 (range 26 to 63 )

Percentage male: intervention: $83 \%$; comparator: $96 \%$

Ethnicity: NR

Interventions

Intervention: Individualised comprehensive CR programme based on the principles of social cognitive theory involved a moderate-intensity walking programme with a graded increase in the frequency and duration of exercise. In the 2 months post- $\mathrm{PCl}$, the clinician made 3 home visits to each participant and went walking with them as part of this visit. In addition, during home visits, participants were taught 
to monitor their rate of perceived exertion (RPE) during their walking programme and to document the frequency, duration and RPE of those sessions in an exercise log.

Components: exercise plus psychological plus education.

Setting: home.

\section{Aerobic exercise:}

Modality: walking

Length of session: not specified - goal setting was based on personalised risk-factor profiles.

\section{Frequency: NR}

Intensity: NR

\section{Resistance training included? No.}

Total duration: not specified.

Co-interventions: The intervention group received the same education sessions as the control group as well as an individualised, comprehensive CR program based on the principles of social cognitive theory. Strategies used to modify risk factors included (1) goal setting, (2) self-monitoring and feedback, (3) skills training, (4) reinforcement of target behaviours and (5) the provision of social support by the clinician. Vocational counselling included specific recommendations regarding return to work. The clinician also made monthly calls when she provided counselling and guidance.

Comparator: Whilst hospitalised, control participants received two, one-to-one bedside education sessions; one $45 \mathrm{~min}$ session pre $\mathrm{PCl}$ and one $60 \mathrm{~min}$ session post- $\mathrm{PCl}$. Teaching media included videotapes of the procedure, photographs of coronary anatomy during the procedure, and equipment. Post-PCI education included providing information about the pathology and risk factors for CHD and instruction on wound and medication management.

Co-interventions: The clinician made 3 monthly post-discharge CHD information-focused telephone calls to each control participant.

\begin{tabular}{ll}
\hline Outcomes & Mortality \\
\hline Source of funding & "Prince Charles Hospital Private Practice Fund supported the research". \\
\hline Conflicts of interest & NR \\
\hline Notes &
\end{tabular}

\section{Risk of bias}

\begin{tabular}{lll}
\hline Bias & Authors' judgement & Support for judgement \\
\hline $\begin{array}{l}\text { Random sequence genera- } \\
\text { tion (selection bias) }\end{array}$ & Unclear risk & "Patients .......were randomly assigned to either control or intervention." \\
\hline $\begin{array}{l}\text { Allocation concealment } \\
\text { (selection bias) }\end{array}$ & Unclear risk & Allocation concealment not described. \\
\hline
\end{tabular}

Blinding of outcome as-

High risk

Assessments do not appear to be blinded.

sessment (detection bias)

All outcomes

\begin{tabular}{|c|c|c|}
\hline $\begin{array}{l}\text { Incomplete outcome data } \\
\text { (attrition bias) }\end{array}$ & High risk & $\begin{array}{l}\text { Although all withdrawals and exclusions were clearly described and the num- } \\
\text { ber of withdrawals were similar in the intervention (5) and control (4) groups, }\end{array}$ \\
\hline
\end{tabular}



groups respectively.

\begin{tabular}{lll}
\hline $\begin{array}{l}\text { Selective reporting (re- } \\
\text { porting bias) }\end{array}$ & Low risk & All outcomes have been reported at all time points. \\
\hline $\begin{array}{l}\text { Groups balanced at base- } \\
\text { line }\end{array}$ & Low risk & $\begin{array}{l}\text { "There were no significant differences between control and intervention } \\
\text { groups on any T1 demographic, risk-factor characteristic, or medical charac- } \\
\text { teristic." }\end{array}$ \\
\hline $\begin{array}{l}\text { Intention-to-treat analysis } \\
\text { conducted }\end{array}$ & High risk & $\begin{array}{l}\text { The paper does not report that an intention-to-treat analysis was conducted, } \\
\text { and does not describe how it deals with missing data. }\end{array}$ \\
\hline $\begin{array}{l}\text { Groups received same } \\
\text { treatment (apart from the } \\
\text { intervention) }\end{array}$ & High risk & $\begin{array}{l}\text { Both groups received the same education sessions, but the Intervention group } \\
\text { also received a comprehensive programme of risk factor modification strate- } \\
\text { gies. }\end{array}$ \\
\hline
\end{tabular}

\begin{tabular}{ll}
\hline Methods & Study design: Single centre RCT \\
& Country: Sweden \\
& Dates patients recruited: February 1993 to December 1995 \\
& Maximum follow up: 2 years \\
\hline Participants & $\begin{array}{l}\text { Inclusion criteria: (a) at least one significant stenosis suitable for PTCA and at least one additional-al- } \\
\text { though clinically nonsignificant-stenosis or plaque, measurable with quantitative computerised an- } \\
\text { giography (QCA); (b) age < } 65 \text { years; (c) employed; (d) absence of other diseases of importance for the } \\
\text { programme or with poor prognosis; and (e) able to perform a bicycle ergometer test with a minimum } \\
\text { exercise capacity of } 70 \text { watts. }\end{array}$
\end{tabular}

Exclusion criteria: None described

N Randomised: total: 87; intervention: 46; comparator: 41

Diagnosis (\% of pts): treated with percutaneous transluminal angioplasty.

Age (mean): intervention: 53; comparator: 53

Percentage male: $83.9 \%$

Ethnicity: NR

Interventions

Intervention: Started with a 4-week residential stay at the intervention unit. The programme included intense health education and activities promoting behavioural changes - stress management, diet, exercise and smoking habits. Each subject was assigned a daily individual task including self-observation, Type A behavioural drills, relaxation training and exercise. Followed by 11-month structured maintenance programme.

Components: Exercise plus psychological plus education.

Setting: Centre followed by home.

Aerobic exercise: NR

Modality: NR

Length of session: NR 
Hofman-Bang 1999 (Continued)

\section{Frequency: NR}

Intensity: NR

Resistance training included? NR

Total duration: 12 months.

Co-interventions: Maintenance programme consisted of continuous self-observation and self-recording of important everyday lifestyle behaviours, feedback of behaviour changes, and of regular follow-up contacts between the patient and his/her personal coach for verbal feedback, problem-solving, and replanning discussions when needed.

Comparator: standard care.

Co-interventions: none described.

Outcomes

Cardiovascular mortality, MI, CABG, PTCA, hospitalisations, health-related quality of life: Angina Pectoris Quality of Life Questionnaire (APQLQ) recorded during the 2 years follow up.

\begin{tabular}{ll}
\hline Source of funding & AMF Insurance Co., the SPP Insurance Co., and The Swedish Heart and Lung Foundation. \\
\hline Conflicts of interest & NR \\
\hline Notes & $\begin{array}{l}93 \text { patients were randomly assigned to an intervention group or a control group, respectively. Six sub- } \\
\text { jects (two in the intervention group and four in the control group) refused further participation in close } \\
\text { connection to randomisation. }\end{array}$
\end{tabular}

\section{Risk of bias}

\begin{tabular}{|c|c|c|}
\hline Bias & Authors' judgement & Support for judgement \\
\hline $\begin{array}{l}\text { Random sequence genera- } \\
\text { tion (selection bias) }\end{array}$ & Unclear risk & "randomly assigned" \\
\hline $\begin{array}{l}\text { Allocation concealment } \\
\text { (selection bias) }\end{array}$ & Unclear risk & Not reported. \\
\hline $\begin{array}{l}\text { Blinding of outcome as- } \\
\text { sessment (detection bias) } \\
\text { All outcomes }\end{array}$ & Unclear risk & Blinding not described. \\
\hline $\begin{array}{l}\text { Incomplete outcome data } \\
\text { (attrition bias) } \\
\text { All outcomes }\end{array}$ & High risk & $21.8 \%$ lost to follow up, no description of withdrawals or dropouts. \\
\hline $\begin{array}{l}\text { Selective reporting (re- } \\
\text { porting bias) }\end{array}$ & Low risk & All outcomes reported at all time points. \\
\hline $\begin{array}{l}\text { Groups balanced at base- } \\
\text { line }\end{array}$ & High risk & Significant difference between groups in use of beta blockers. \\
\hline $\begin{array}{l}\text { Intention-to-treat analysis } \\
\text { conducted }\end{array}$ & High risk & No. \\
\hline $\begin{array}{l}\text { Groups received same } \\
\text { treatment (apart from the } \\
\text { intervention) }\end{array}$ & High risk & $\begin{array}{l}\text { "Subjects in the intervention group participated in a comprehensive behav- } \\
\text { iorally oriented program aimed at achieving significant long-term changes in } \\
\text { risk factor-related lifestyle behavior....included health education and behav- } \\
\text { ior-change activities, including lectures and discussions, habit rehearsal di- } \\
\text { rected toward stress management and diet, exercise, and smoking habits. ....." }\end{array}$ \\
\hline
\end{tabular}


Country: Sweden

Dates patients recruited: "during a 2-year period"

Maximum follow up: $1 \mathrm{yr}$

\section{Participants}

Inclusion criteria: Acute MI patients under 65 years of age.

Exclusion criteria: Not stated but patients have been excluded for being incapable of performing strenuous training due to poor left ventricular function or arrhythmias, orthopaedic disorders, other incapacitating somatic diseases or mental disorders.

N Randomised: total: 69; intervention: 34; comparator:35

Diagnosis (\% of pts): Post-MI: $100 \%$

Age (mean years [range]): intervention: 55 (38-65); comparator:55 (43-63)

Percentage male: $97 \%$

Ethnicity: NR

Interventions

Intervention: Started 8 weeks post-MI and patients trained over a 12-week period for at least 45 minutes (effective time) twice a week with interval training involving large muscle groups: bicycling (10 $\mathrm{min})$, calisthenics (10 $\mathrm{min})$, jogging (15 min) ending with relaxation (10 min).

Components: exercise only.

Setting: not described, but assumed in a centre.

\section{Aerobic exercise:}

Modality: bicycling 10 mins, $10 \mathrm{~min}$, jogging.

Length of session: at least 45 mins.

Frequency: twice per week.

Intensity: $70 \%$ to $85 \%$ of peak heart at the bicycle test for initial session and workload individually adjusted to obtain the desired maximum heart rate if possible.

Resistance training included? callisthenics.

Total duration: 12 weeks.

Co-interventions: none described.

Comparator: recieved regular medical care with no emphasis on exercise.

Co-interventions: none described.

Outcomes

Total mortality, non-fatal MI \& revascularisation.

Health-related quality of life: self-report questionnaire.

Evaluations at 6 weeks and 1 year post MI.

\section{Source of funding}

Conflicts of interest
Research support was given by Malmöhus County Council. 
Holmbäck 1994 (Continued)

Notes

Study authors found no benefit from exercise training. Outcomes were related to self-rated levels of physical and psychological well being.

\section{Risk of bias}

\begin{tabular}{|c|c|c|}
\hline Bias & Authors' judgement & Support for judgement \\
\hline $\begin{array}{l}\text { Random sequence genera- } \\
\text { tion (selection bias) }\end{array}$ & Low risk & $\begin{array}{l}\text { "Randomization was performed according to random numbers in sealed en- } \\
\text { velopes". }\end{array}$ \\
\hline $\begin{array}{l}\text { Allocation concealment } \\
\text { (selection bias) }\end{array}$ & Low risk & $\begin{array}{l}\text { "Randomization was performed according to random numbers in sealed en- } \\
\text { velopes". }\end{array}$ \\
\hline $\begin{array}{l}\text { Blinding of outcome as- } \\
\text { sessment (detection bias) } \\
\text { All outcomes }\end{array}$ & Low risk & Evaluations were "supervised by independent investigators". \\
\hline $\begin{array}{l}\text { Incomplete outcome data } \\
\text { (attrition bias) } \\
\text { All outcomes }\end{array}$ & High risk & $14.5 \%$ lost to follow up, no description of withdrawals or dropouts. \\
\hline $\begin{array}{l}\text { Selective reporting (re- } \\
\text { porting bias) }\end{array}$ & Low risk & $\begin{array}{l}\text { All outcomes reported for all time points (although absolute values not always } \\
\text { given). }\end{array}$ \\
\hline $\begin{array}{l}\text { Groups balanced at base- } \\
\text { line }\end{array}$ & Low risk & Balanced except some some differences in MI situation. \\
\hline $\begin{array}{l}\text { Intention-to-treat analysis } \\
\text { conducted }\end{array}$ & High risk & No. \\
\hline $\begin{array}{l}\text { Groups received same } \\
\text { treatment (apart from the } \\
\text { intervention) }\end{array}$ & Low risk & $\begin{array}{l}\text { "Patients were randomised to either an exercise or a non-exercise group..... } \\
\text { No special psychosocial benefits were given to the training group. The control } \\
\text { group received regular medical care with no special emphasis on exercise." }\end{array}$ \\
\hline
\end{tabular}

Houle 2012

Methods Study design: Multicentre RCT (2 sites)

Country: Canada

Dates patients recruited: April 2007 to April 2008

Maximum follow up: 12 months

Inclusion criteria: Patients hospitalised for an ACS (unstable angina, non-ST-elevation or ST elevation myocardial infarction) and willing to travel to the CR centre every 3 months to meet the clinical nurse specialist and able to read and speak French.

Exclusion criteria: Inability to perform activities of daily living (such as feeding themselves, bathing, dressing, grooming, work, homemaking, and leisure); enrolment in another research project or in a heart failure clinic where serial follow-up creates a bias and contraindication to exercise testing; medical diagnosis of debilitating chronic illness (such as cancer without remission), musculoskeletal or neurological disorder (such as multiple sclerosis, Parkinson's disease, etc); subjects with a previous history of stroke could be included if they had no residual effects related to their stroke); serious and unstable mental incapacities or major depression.

N Randomised: total: 65; intervention: 32; comparator: 33 
Houle 2012 (Continued)

\section{Diagnosis ( $\%$ of pts):}

Unstable angina: intervention: 50\%; comparator: 52\%

STeMI: intervention: $28 \%$; comparator: $27 \%$

Non STeMI: intervention:22\%; comparator: $21 \%$

Age (mean \pm SD): intervention: $58 \pm 8$; comparator: $59 \pm 9$

Percentage male: total: $78 \%$; intervention: $81 \%$; comparator: $76 \%$

Ethnicity: NR

Interventions

Intervention: Participants received a pedometer-based programme concomitantly with a socio-cognitive intervention led by a clinical nurse specialist. Participants used 1 pedometer blinded and used a second one to monitor their daily steps since discharge.

Components: Exercise plus education plus socio-cognitive intervention.

Setting: home.

\section{Aerobic exercise:}

Modality: walking.

Length of session: not specified.

Frequency: not specified.

Intensity: not specified.

Resistance training included? No.

Total duration: 12 months.

Co-interventions: Participants received received a socio-cognitive intervention led by a clinical nurse specialist, and a blinded pedometer with instructions about how to wear the pedometer correctly during 7 consecutive days from morning to bedtime.

Comparator: Patients received the usual advice by the nurse or the physician, or both at discharge regarding physical activity, diet, and medication. They had no restriction to go to a centre-based cardiac rehabilitation programme or to consult a health care professional such as a nutritionist, an exercise specialist, or a psychologist. Subjects in both groups received usual medical follow-up by their own physicians (cardiologist and family physician).

Co-interventions: Participants received a blinded pedometer and instructions about how to wear the pedometer correctly during 7 consecutive days from morning to bedtime.

Outcomes HRQL

Source of funding Heart and Stroke Foundation of Canada, Research centre of Institut Universitaire de Cardiologie et Pneumologie de Québec, and Pfizer Canada.

\section{Risk of bias}

Bias Authors' judgement Support for judgement


Houle 2012 (Continued)

\begin{tabular}{|c|c|}
\hline $\begin{array}{l}\text { Random sequence genera- Low risk } \\
\text { tion (selection bias) }\end{array}$ & $\begin{array}{l}\text { "They were randomly allocated to the experimental group or to the usual care } \\
\text { group using a randomization table". }\end{array}$ \\
\hline
\end{tabular}
tion (selection bias) group using a randomization table".

Allocation concealment Unclear risk
(selection bias)

\begin{tabular}{|c|c|c|}
\hline $\begin{array}{l}\text { Blinding of outcome as- } \\
\text { sessment (detection bias) } \\
\text { All outcomes }\end{array}$ & Unclear risk & $\begin{array}{l}\text { Physical activity recorded by a blinded pedometer. However, blinding of as- } \\
\text { sessors of other tests and measurements not described. }\end{array}$ \\
\hline $\begin{array}{l}\text { Incomplete outcome data } \\
\text { (attrition bias) } \\
\text { All outcomes }\end{array}$ & High risk & $\begin{array}{l}\text { Loss to follow up was high in both groups: } 9 / 32 \text { [28\%] and } 11 / 33[33 \%] \text { were } \\
\text { lost to follow up from the Intervention and control groups. }\end{array}$ \\
\hline $\begin{array}{l}\text { Selective reporting (re- } \\
\text { porting bias) }\end{array}$ & Low risk & $\begin{array}{l}\text { All outcomes were reported at all time points described either in the paper or } \\
\text { in the supplementary material online. }\end{array}$ \\
\hline $\begin{array}{l}\text { Groups balanced at base- } \\
\text { line }\end{array}$ & Low risk & "Group characteristics were comparable (Table 1)." \\
\hline $\begin{array}{l}\text { Intention-to-treat analysis } \\
\text { conducted }\end{array}$ & Low risk & "The data was analyzed using an "intention to treat" approach." \\
\hline $\begin{array}{l}\text { Groups received same } \\
\text { treatment (apart from the } \\
\text { intervention) }\end{array}$ & Low risk & $\begin{array}{l}\text { "Subjects in both groups received usual medical follow-up by their own physi- } \\
\text { cians (cardiologist and family physician) and...... received a blinded pedome- } \\
\text { ter and instructions about how to wear the pedometer correctly during } 7 \text { con- } \\
\text { secutive days from morning to bedtime" }\end{array}$ \\
\hline
\end{tabular}

Kallio 1979

\begin{tabular}{|c|c|}
\hline Methods & $\begin{array}{l}\text { Study design: Multicentre RCT ( } 2 \text { sites) } \\
\text { Country: Finland } \\
\text { Dates patients recruited: May 1973, to October } 1975 \\
\text { Maximum follow up: } 3 \text { years }\end{array}$ \\
\hline Participants & $\begin{array}{l}\text { Inclusion criteria: Patients treated in hospital for acute myocardial infarction based on WHO criteria. } \\
\text { Exclusion criteria: NR } \\
\text { N Randomised: total: } 375 \text {; intervention: } 188 \text {; comparator: } 187 \\
\text { Diagnosis (\% of pts): AMI: } 100 \% \\
\text { Age (mean): intervention: } 54.4 \text {; comparator: } 54.1 \\
\text { Percentage male: } 80.3 \% \\
\text { Ethnicity: NR }\end{array}$ \\
\hline Interventions & $\begin{array}{l}\text { Intervention: The programme was started two weeks after discharge from hospital and consisted of } \\
\text { medical examinations by an internist at least monthly for the first six months after AMI, then when nec- } \\
\text { essary or at least 3-monthly. A physical exercise programme, tailored to the individual's working capac- } \\
\text { ity determined in a bicycle ergometer test, was recommended, and for most patients it was done under } \\
\text { supervision. The rehabilitation programme was most intensive during the first three months after my- } \\
\text { ocardial infarction. }\end{array}$ \\
\hline
\end{tabular}


Kallio 1979 (Continued)

Components: Exercise, education and psyochological.

Setting: Supervised in a centre.

\section{Aerobic exercise:}

Modality: NR

Length of session: NR

Frequency: NR

Intensity: NR

Resistance training included? NR

Total duration: NR

Co-interventions: Besides the internist the team included a social worker, a psychologist, a dietitian, and a physiotherapist. Health education consisted of anti-smoking and dietary advice, and discussions on psychosocial problems.

Comparator: usual care.

Co-interventions: none described.

Outcomes Total mortality; cardiovascular mortality (follow-up 3 years).

Source of funding Social Insurance Institution.

Conflicts of interest NR

\section{Notes}

\section{Risk of bias}

\begin{tabular}{|c|c|c|}
\hline Bias & Authors' judgement & Support for judgement \\
\hline $\begin{array}{l}\text { Random sequence genera- } \\
\text { tion (selection bias) }\end{array}$ & Unclear risk & "randomly allocated" \\
\hline $\begin{array}{l}\text { Allocation concealment } \\
\text { (selection bias) }\end{array}$ & Unclear risk & Not reported. \\
\hline $\begin{array}{l}\text { Blinding of outcome as- } \\
\text { sessment (detection bias) } \\
\text { All outcomes }\end{array}$ & Unclear risk & Blinding not described. \\
\hline $\begin{array}{l}\text { Incomplete outcome data } \\
\text { (attrition bias) } \\
\text { All outcomes }\end{array}$ & Low risk & $1 \%$ lost to follow up. \\
\hline $\begin{array}{l}\text { Selective reporting (re- } \\
\text { porting bias) }\end{array}$ & Low risk & All outcomes reported at all time points. \\
\hline $\begin{array}{l}\text { Groups balanced at base- } \\
\text { line }\end{array}$ & Low risk & $\begin{array}{l}\text { "The differences between the two groups were insignificant as regards past illi- } \\
\text { ness and findings during the present illness." }\end{array}$ \\
\hline $\begin{array}{l}\text { Intention-to-treat analysis } \\
\text { conducted }\end{array}$ & High risk & No. \\
\hline
\end{tabular}


Kallio 1979 (Continued)

Groups received same treatment (apart from the intervention)
High risk

"As well as an internist, the team consisted of a social worker, a psychologist, a dietician and a physiotherapist..... Health education consisted of anti-smoking and dietary advice, and discussions on psychosocial problems."

\section{Kovoor 2006}

Methods

Study design: Multicentre RCT (2 sites)

Country: Australia

Dates patients recruited: NR

Maximum follow up: 6 months

\section{Participants}

Inclusion criteria: AMI; < 75 years of age; no angina; $<2 \mathrm{~mm} \mathrm{ST-segment} \mathrm{depression} \mathrm{with} \mathrm{exercise} \mathrm{and}$ if they attained $>7$-METS workload; left ventricular ejection fraction $>40 \%$ or no inducible ventricular tachycardia.

Exclusion criteria: Patients were excluded if there was $2 \mathrm{~mm}$ ST-segment depression with exercise or if 7-METS workload was attained.

N Randomised: total: 142; intervention: 70; comparator: 72

Diagnosis (\% of pts): AMI: $100 \%$

Age (mean): intervention: 56.2; comparator: 55.8

Percentage male: intervention: $89 \%$; comparator: $86 \%$

Ethnicity: NR

Interventions

Intervention: Exercise (conventional treatment group): 5 week rehabilitation program consisted of exercise, education, and counselling sessions that were held 2 to 4 times per week, including work at 6 weeks after AMI.

Components: Exercise, education and psychological.

Setting: NR

Aerobic exercise:

Modality: NR

Length of session: NR

Frequency: 2 to 4 times per week.

Intensity: NR

Resistance training included? NR

Total duration: 5 weeks

Co-interventions: The 2 groups of patients were encouraged to exercise at home on a regular basis. $\mathrm{Pa}$ tients were given the telephone numbers of the cardiologist and the nurse co-ordinator so they could be contacted in case of problems.

Comparator: Control group (ERNA - early return to normal activities group): return to work at 2 weeks after AMI without a formal CR programme.

Co-interventions: This group of patients was contacted over the telephone by the nurse co-ordinator once per week for 5 weeks. The 2 groups of patients were encouraged to exercise at home on a regu- 
Kovoor 2006 (Continued)

lar basis. Patients were given the telephone numbers of the cardiologist and the nurse co-ordinator so they could be contacted in case of problems.

\begin{tabular}{ll}
\hline Outcomes & Total mortality; fatal/non-fatal mortality; CABG; PCl; HRQL. Costs reported in Hall 2002 \\
& Assessment at 6 weeks and at 6 months. \\
\hline Source of funding & National Health and Medical Research Council, Sydney, Australia. \\
\hline Conflicts of interest & NR \\
\hline Notes &
\end{tabular}

\section{Risk of bias}

\begin{tabular}{|c|c|c|}
\hline Bias & Authors' judgement & Support for judgement \\
\hline $\begin{array}{l}\text { Random sequence genera- } \\
\text { tion (selection bias) }\end{array}$ & Unclear risk & Method of randomisation not described. \\
\hline $\begin{array}{l}\text { Allocation concealment } \\
\text { (selection bias) }\end{array}$ & Low risk & $\begin{array}{l}\text { "Randomization schedules were generated by an independent investigator } \\
\text { and were kept in opaque sealed envelopes." }\end{array}$ \\
\hline $\begin{array}{l}\text { Blinding of outcome as- } \\
\text { sessment (detection bias) } \\
\text { All outcomes }\end{array}$ & Unclear risk & $\begin{array}{l}\text { "GHPS .... scans being analyzed in a blinded fashion by an independent nu- } \\
\text { clear medicine specialist." Blinding of other outcome assessments not de- } \\
\text { scribed. }\end{array}$ \\
\hline $\begin{array}{l}\text { Incomplete outcome data } \\
\text { (attrition bias) } \\
\text { All outcomes }\end{array}$ & High risk & $20.4 \%$ lost to follow-up, no description of withdrawals or dropouts. \\
\hline $\begin{array}{l}\text { Selective reporting (re- } \\
\text { porting bias) }\end{array}$ & Low risk & All outcomes reported all time points. \\
\hline $\begin{array}{l}\text { Groups balanced at base- } \\
\text { line }\end{array}$ & High risk & $\begin{array}{l}\text { "At the time of randomization, there was a larger number of patients }(p=0.02) \\
\text { in the conventional treatment group who never adhered to a low-cholesterol, } \\
\text { low-fat diet than in the ERNA group." }\end{array}$ \\
\hline $\begin{array}{l}\text { Intention-to-treat analysis } \\
\text { conducted }\end{array}$ & Low risk & Yes. \\
\hline $\begin{array}{l}\text { Groups received same } \\
\text { treatment (apart from the } \\
\text { intervention) }\end{array}$ & High risk & $\begin{array}{l}\text { "conventional treatment group" = 5-week rehabilitation program which con- } \\
\text { sisted of exercise, education, and counselling sessions that were held } 2 \text { to } 4 \\
\text { times per week vs "early return to normal activities group" = return to full nor- } \\
\text { mal activities, including work at } 2 \text { weeks, after AMI without a formal rehabilita- } \\
\text { tion programme. }\end{array}$ \\
\hline
\end{tabular}

La Rovere 2002

\begin{tabular}{ll}
\hline Methods & Study design: Single centre RCT \\
Country: Italy \\
Dates patients recruited: 1984 to 1985 \\
Maximum follow up: 10 yrs \\
\hline
\end{tabular}


La Rovere 2002 (Continued)

Participants
Inclusion criteria: Post-MI patients admitted at Centro Medico di Montescano in 1984 to 1985

Exclusion criteria: Atrial fibrillation or abnormal sinus node function, insulin-dependent diabetes, exercise-induced myocardial ischemia, and arterial BP > 160/90.

N Randomised: total: 95; intervention: 49; comparator: 46

Diagnosis (\% of pts): uncomplicated MI: $100 \%$

Age (mean): intervention: 51; comparator: 52

Percentage male: $100 \%$

Ethnicity: NR

Interventions

Intervention: The exercise sessions (30 minutes, 5 times a week) consisted of calisthenics and stationary bicycle ergometry.

Components: Exercise, education and psychological.

Setting: Supervised in a centre.

\section{Aerobic exercise:}

Modality: stationary bicycle ergometry.

Length of session: 30 minutes.

Frequency: 5 times a week.

Intensity: $75 \%$ of heart rate at peak $\mathrm{VO}_{2}$, rising to $85 \%$ in the second and third weeks and $95 \%$ in the final week.

Resistance training included? Callisthenics.

Total duration: 4-weeks.

Co-interventions: Sessions were held by cardiologists and psychologists, dealing with secondary prevention of cardiovascular disease and stressing dietary changes and smoking cessation.

Comparator: No training.

Co-interventions: All patients attended sessions, held by a cardiologist and a psychologist, dealing with secondary prevention of cardiovascular disease and stressing dietary changes and smoking cessation.

Outcomes

Cardiac mortality; nonfatal Ml; CABG at 3 to 4 month intervals from the time of entry into the study for the first 3 years and contacted periodically by telephone thereafter.

Source of funding NR

Conflicts of interest NR

Notes

\section{Risk of bias}

\begin{tabular}{lll}
\hline Bias & Authors' judgement & Support for judgement \\
\hline $\begin{array}{l}\text { Random sequence genera- } \\
\text { tion (selection bias) }\end{array}$ & Unclear risk & "randomized" \\
\hline
\end{tabular}


La Rovere 2002 (Continued)

Allocation concealment $\quad$ Unclear risk $\quad$ Not reported.
(selection bias)

\begin{tabular}{lll}
\hline Blinding of outcome as- & Unclear risk & Blinding not described. \\
sessment (detection bias)
\end{tabular}

All outcomes

\begin{tabular}{l}
\hline Incomplete outcome data Low risk $\quad$ All patients accounted for. \\
(attrition bias) \\
All outcomes
\end{tabular}

Selective reporting (re- High risk $\quad$ Results not reported for all time points collected.
porting bias)

\begin{tabular}{lll}
\hline $\begin{array}{l}\text { Groups balanced at base- } \\
\text { line }\end{array}$ & Low risk & $\begin{array}{l}\text { "There were no significant differences in age, site of MI, left ventricular ejection } \\
\text { fraction, and extent of coronary artery disease." }\end{array}$ \\
\hline $\begin{array}{l}\text { Intention-to-treat analysis } \\
\text { conducted }\end{array}$ & Low risk & Yes. \\
\hline $\begin{array}{l}\text { Groups received same } \\
\text { treatment (apart from the } \\
\text { intervention) }\end{array}$ & Low risk & $\begin{array}{l}\text { "Patients were randomized to a 4-week training period or to a control group. } \\
\text { The exercise sessions (30 minutes, } 5 \text { times a week) consisted of calisthenics } \\
\text { and stationary bicycle ergometry" }\end{array}$ \\
& $\begin{array}{l}\text { "All patients attended sessions, held by a cardiologist and a psychologist, deal- } \\
\text { ing with secondary prevention of cardiovascular disease and stressing dietary } \\
\text { changes and smoking cessation." }\end{array}$ \\
\hline
\end{tabular}

Leizorovicz 1991

\begin{tabular}{ll}
\hline Methods & Study design: Multicentre RCT (4 sites) \\
Country: France \\
Dates patients recruited: February 1981 to May 1984 \\
Maximum follow up: 2 years \\
Inclusion criteria: Admitted to participating coronary care units with suspected MI; <65 years old with \\
typical MI, no major irreversible complication or disability. \\
Exclusion criteria: Contraindication to exercise testing i.e., recent stroke, disability of lower limbs, un- \\
Controlled heart failure, severe rhythm disturbances, SBP > 180 mmHg, severe angina pectoris, or ab- \\
normalities triggered by baseline exercise test. \\
N Randomised: total: $182 ;$ intervention: 61 ; comparator (usual care): 60 counselling programme: 61 (no \\
data analysed in this review) \\
Diagnosis (\% of pts): MI: $100 \%$ \\
Age (mean): intervention: $51 ;$ comparator: 49 \\
Percentage male: $100 \%$ \\
Ethnicity: NR
\end{tabular}

Interventions

Intervention: The programme started within a few days of randomisation and included three training sessions a week on a cycloergometer, walking and gymnastics.

Components: Exercise and education. 
Leizorovicz 1991 (Continued)

\section{Setting: Centre.}

\section{Aerobic exercise:}

Modality: cycloergometer, walking and gymnastics.

Length of session: $25 \mathrm{~min}$.

Frequency: 3 times per week.

Intensity: $80 \%$ of max HR and then decreased progressively over 2 min (increased as the sessions progressed).

\section{Resistance training included? No.}

Total duration: 6 weeks.

Co-interventions: Also included respiratory physiotherapy, relaxation, recommendations on control of cardiovascular risk factors (smoking habits, diet); recommendations to continue regular physical training at the end of the 6-week programme.

Comparator: Patients in the usual care group were referred to their usual private practioner or cardiologist or both.

Co-interventions: None described.

\begin{tabular}{ll}
\hline Outcomes & Non fatal MI, angina, surgery. \\
\hline Source of funding & $\begin{array}{l}\text { Institut National de la Same et de la Recherche Medicale, by the Hospices Civils de Lyon and by the } \\
\text { Association pour la Promotion et la Realisation d'Essais Therapeutiques. }\end{array}$ \\
\hline Conflicts of interest & NR \\
\hline Notes & $\begin{array}{l}\text { Only } 14 \% \text { of all MI patients admitted to the participating hospitals were randomised to the trial. Exclu- } \\
\text { sion of women and patients }>65 \text { accounted for } 60 \% \text { of exclusions. }\end{array}$
\end{tabular}

\section{Risk of bias}

\begin{tabular}{lll}
\hline Bias & Authors' judgement & Support for judgement \\
\hline $\begin{array}{l}\text { Random sequence genera- } \\
\text { tion (selection bias) }\end{array}$ & Unclear risk & Not reported. \\
\hline $\begin{array}{l}\text { Allocation concealment } \\
\text { (selection bias) }\end{array}$ & Unclear risk & Not reported. \\
\hline $\begin{array}{l}\text { Blinding of outcome as- } \\
\text { sessment (detection bias) } \\
\text { All outcomes }\end{array}$ & Unclear risk & Blinding not described. \\
\hline $\begin{array}{l}\text { Incomplete outcome data } \\
\text { (attrition bias) } \\
\text { All outcomes }\end{array}$ & Low risk & No losses to follow up. \\
\hline $\begin{array}{l}\text { Selective reporting (re- } \\
\text { porting bias) }\end{array}$ & Low risk & $\begin{array}{l}\text { All outcomes reported for all time points (although absolute values not always } \\
\text { given). }\end{array}$ \\
\hline $\begin{array}{l}\text { Groups balanced at base- } \\
\text { line }\end{array}$ & Low risk & "Baseline characteristics were identical in the three groups". \\
\hline
\end{tabular}


Leizorovicz 1991 (Continued)

Intention-to-treat analysis Low risk Yes. conducted

Groups received same treatment (apart from the intervention)
High risk

\begin{abstract}
"The rehabilitation programme .... included: three training sessions a week on a cycloergometer; walking; gymnastic and respiratory physiotherapy; relaxation; recommendations on control of cardiovascular risk factors (smoking habits, diet); recommendations to continue regular physical training at the end of the 6-week programme."

"Patients randomized to CP attended a group session with a cardiologist, a psychiatrist, a nutritionist and a physiotherapist whenever possible.......Patients in the UC group were just referred to their usual private practioner and/ or cardiologist."
\end{abstract}

\begin{tabular}{ll}
\hline Methods & Study design: Single centre RCT \\
Country: Scotland, UK \\
Dates patients recruited: March 1988 to March 1991 \\
Maximum follow up: 1 year \\
\hline Inclusion criteria: Confirmed MI (WHO criteria); age less than 80 years; able to speak and read English; \\
resident in the hospital catchment area. \\
Exclusion criteria: Known history of major psychiatric illness; current psychotic symptoms; evidence \\
of dementia or continuing uncontrolled arrhythmias or heart failure. \\
N Randomised: total: $176 ;$ intervention: $88 ;$ comparator: 88 \\
Diagnosis (\% of pts): MI: $100 \%$ \\
Age (mean \pm SD): intervention: $55.3 \pm 10.7 ;$ comparator: $56.3 \pm 10.5$ \\
Percentage male: intervention: $70.0 \%$; comparator: $72.7 \%$ \\
Ethnicity: NR
\end{tabular}

Components: Exercise, education and psychological.

Setting: home.

Aerobic exercise: NR

Modality: NR

Length of session: NR

Frequency: NR

Intensity: NR

Resistance training included? NR

Total duration: 6 weeks. 
Lewin 1992 (Continued)

Co-interventions: Specific self-help treatments were provided for psychological problems commonly experienced by post-MI patients. Before the patient was discharged from hospital spouses were given an audiotape that provided information and advice. After discharge the facilitator made contact with both groups of patients at 1,3, and 6 weeks, by telephone, at a hospital clinic, or, when neither of these was possible, by brief home visits.

Comparator: The control group received an equal amount of the facilitator's time (approximately 10 $\min )$.

Co-interventions: Patients were given an extensive package of leaflets from various sources, intended to cover the same information as that presented in the manual.

\begin{tabular}{ll}
\hline Outcomes & HRQL, Hospital Anxiety and Depression Scale (HAD), General Health Questionnaire (GHQ). \\
\hline Source of funding & $\begin{array}{l}\text { This research was supported by a grant from the Chief Scientist Office of the Scottish Home and Health } \\
\text { Department. The British Heart Foundation donated additional computer equipment. }\end{array}$ \\
\hline Conflicts of interest & NR \\
\hline Notes & $\begin{array}{l}\text { Study terminated (due to expiry of funding) before all pts reached } 6 \text { or 12-month stage. } \\
\text { Anxiety scores showed significant treatment effect @ } 6 \text { weeks and 1 year, depression @ } 6 \text { weeks. } \\
\text { Pre hospital discharge 52\% of all pts had HAD scores indicating clinically significant anxiety or depres- } \\
\text { sion (8+). C were significantly more anxious and depressed at all follow ups. }\end{array}$
\end{tabular}

\section{Risk of bias}

\begin{tabular}{lll}
\hline Bias & Authors' judgement & Support for judgement \\
\hline $\begin{array}{l}\text { Random sequence genera- } \\
\text { tion (selection bias) }\end{array}$ & Unclear risk & $\begin{array}{l}\text { "allocated to the experimental or control group by use of a written pre-deter- } \\
\text { mined randomisation protocol". Method of randomisation not described. }\end{array}$ \\
\hline $\begin{array}{l}\text { Allocation concealment } \\
\text { (selection bias) }\end{array}$ & Unclear risk & Allocation concealment not described. \\
\hline $\begin{array}{l}\text { Blinding of outcome as- } \\
\text { sessment (detection bias) } \\
\text { All outcomes }\end{array}$ & Low risk & $\begin{array}{l}\text { "Questionnaires were scored and the data entered into the statistical analysis } \\
\text { programme by a clerical assistant based at a separate hospital who was blind } \\
\text { both to the experimental design and } \\
\text { to the patients." }\end{array}$ \\
\hline
\end{tabular}

Incomplete outcome data High risk 17\% lost to follow up, no description of withdrawals or dropouts.

(attrition bias)

All outcomes

\begin{tabular}{lll}
\hline $\begin{array}{l}\text { Selective reporting (re- } \\
\text { porting bias) }\end{array}$ & Low risk & All outcomes reported at all time points. \\
\hline $\begin{array}{l}\text { Groups balanced at base- } \\
\text { line }\end{array}$ & High risk & $\begin{array}{l}\text { "Before intervention there were no major differences between the rehabilita- } \\
\text { tion and control groups in any of the demographic or physiological measures, } \\
\text { but the controls were less likely to be working and to have had a previous MI. } \\
\text { There was a tendency for the rehabilitation group to be more distressed than } \\
\text { controls on all psychological variables." }\end{array}$ \\
\hline
\end{tabular}

Intention-to-treat analysis High risk No.

conducted

No.

\begin{tabular}{|c|c|c|}
\hline $\begin{array}{l}\text { Groups received same } \\
\text { treatment (apart from the } \\
\text { intervention) }\end{array}$ & High risk & $\begin{array}{l}\text { "The final version consisted of six weekly sections that included education, } \\
\text { a home-based exercise programme, and a tape-based relaxation and stress } \\
\text { management programme".Groups received same treatment (apart from the } \\
\text { intervention). }\end{array}$ \\
\hline
\end{tabular}


Country: New Zealand

Dates patients recruited: 2010 to 2012

Maximum follow up: 24 weeks

Participants

Inclusion criteria: Aged 18 years or more, with a diagnosis of IHD, defined as angina, myocardial infarction, revascularisation, including angioplasty, stent or coronary artery bypass graft within the previous 3 to 24 months. All participants were clinically stable as outpatients, able to perform exercise, able to understand and write English, and had access to the Internet (e.g. at home, work, library or through friends or relatives).

Exclusion criteria: Patients were excluded if they had been admitted to hospital with heart disease within the previous 6 weeks; had terminal cancer, or had significant exercise limitations other than IHD

N Randomised: total: 171; intervention: 85; comparator: 86

\section{Diagnosis ( $\%$ of pts):}

IHD: $100 \%$

MI: $74 \%$

Angina: $50 \%$

Age (mean \pm SD): total: $60.2 \pm 9.3$; intervention: $61.4 \pm 8.9$; comparator: $59.0 \pm 9.5$

Percentage male: total: $81 \%$; intervention: $81 \%$; comparator: $81 \%$

\section{Ethnicity:}

NZ Maori: total: $8 \%$; intervention: $7 \%$; comparator: $8 \%$

Pacific: total: 6\%; intervention: 6\%; comparator: $6 \%$

Asian: total: 10\%; intervention: $9 \%$; comparator: $10 \%$

NZ European/other: total: 76\%; intervention: 78\%; comparator: 76\%

Intervention: The HEART programme is a personalised, automated package of text messages via mobile phones aimed at increasing exercise behaviour over 24 weeks. Patients received six messages per week for the first 12 weeks, five messages per week for 6 weeks, and then four messages per week for the remaining 6 weeks.

Components: exercise.

Setting: home.

\section{Aerobic exercise:}

Modality: moderate to vigorous aerobic-based exercise e.g. walking and household chores.

Length of session: minimum of 30 minutes.

Frequency: at least 5 days/week.

Intensity: NR

Resistance training included? No.

Total duration: 24 weeks.

Co-interventions: focus on altering the key mediators of behaviour change, including self-efficacy, social support and motivation. 
Comparator: usual care, with encouragement to be physically active and attend a cardiac club.

Co-interventions: All participants were free to participate in any other CR service or support that they wished to use e.g. participating in community-based CR education sessions on modifying CVD risk factors and psychological support, as well as encouragement to be physically active.

\begin{tabular}{ll}
\hline Outcomes & HRQL, costs. \\
\hline Source of funding & $\begin{array}{l}\text { Health Research Council of New Zealand and the Heart Foundation. Dr Maddison was supported by a } \\
\text { Heart Foundation Research Fellowship and a Health Research Council Sir Charles Hercus Research Fel- } \\
\text { lowship. }\end{array}$
\end{tabular}

Conflicts of interest None declared.

\section{Notes}

\section{Risk of bias}

\begin{tabular}{|c|c|c|}
\hline Bias & Authors' judgement & Support for judgement \\
\hline $\begin{array}{l}\text { Random sequence genera- } \\
\text { tion (selection bias) }\end{array}$ & Low risk & $\begin{array}{l}\text { "....were randomly allocated..... by means of a central computerized service. } \\
\text { Randomization was conducted using the minimization method, stratifying by } \\
\text { sex (male and female), ethnicity (Maori - indigenous - and non-Maori), and ex- } \\
\text { ercise history" }\end{array}$ \\
\hline $\begin{array}{l}\text { Allocation concealment } \\
\text { (selection bias) }\end{array}$ & Low risk & "Allocation concealment was maintained up to the point of randomization" \\
\hline $\begin{array}{l}\text { Blinding of outcome as- } \\
\text { sessment (detection bias) } \\
\text { All outcomes }\end{array}$ & Low risk & $\begin{array}{l}\text { "This was a single-blind trial, where outcome assessors were blinded to treat- } \\
\text { ment allocation" }\end{array}$ \\
\hline $\begin{array}{l}\text { Incomplete outcome data } \\
\text { (attrition bias) } \\
\text { All outcomes }\end{array}$ & Low risk & $\begin{array}{l}\text { Loss to follow-up was well reported and was similar in both groups. } 10 / 85 \\
{[12 \%] \text { and } 8 / 86[9 \%] \text { were lost to follow up from the Intervention and control }} \\
\text { groups. }\end{array}$ \\
\hline $\begin{array}{l}\text { Selective reporting (re- } \\
\text { porting bias) }\end{array}$ & Low risk & All outcomes described in the methods section are reported in results. \\
\hline $\begin{array}{l}\text { Groups balanced at base- } \\
\text { line }\end{array}$ & Low risk & "Treatment groups were well balanced at baseline." \\
\hline $\begin{array}{l}\text { Intention-to-treat analysis } \\
\text { conducted }\end{array}$ & Low risk & $\begin{array}{l}\text { "Treatment evaluations were performed on the principle of intention to treat } \\
\text { (ITT), using data collected from all randomized participants." }\end{array}$ \\
\hline $\begin{array}{l}\text { Groups received same } \\
\text { treatment (apart from the } \\
\text { intervention) }\end{array}$ & Low risk & $\begin{array}{l}\text { "All participants were free to participate in any other CR service or support that } \\
\text { they wished to use.......In addition, participants in the intervention group re- } \\
\text { ceived the HEART programme." }\end{array}$ \\
\hline
\end{tabular}

Manchanda 2000

Methods Study design: Single centre RCT

Country: India

Dates patients recruited: NR 
Manchanda 2000 (Continued)

\section{Maximum follow up: 1 year}

Participants

Inclusion criteria: Chronic stable angina and angiographically proven CAD.

Exclusion criteria: Recent (within last six months) MI or unstable angina.

N Randomised: total: 42; intervention: 21; comparator: 21

Diagnosis (\% of pts): chronic stable angina and angiographically proven CAD.

Age (years): intervention: 51; comparator: 52

Percentage male: intervention: $100 \%$; comparator: $100 \%$

Ethnicity: NR

Interventions

Intervention: Patients and their spouses spent four days at a yoga residential centre where they underwent training in various yogic lifestyle techniques. Subsequently they carried out the yogic exercises at home for an average of $90 \mathrm{~min}$ daily. The programme included health rejuvenating exercises, breathing exercises, relaxation, meditation, reflection, stress management, dietary control and moderate aerobic exercises.

Components: exercise, education and psychosocial support.

Setting: centre followed by home.

\section{Aerobic exercise:}

Modality: yoga and "moderate aerobic exercises".

Length of session: $90 \mathrm{~min}$.

Frequency: daily.

Intensity: NR

Resistance training included? No.

Total duration: 1 year.

Co-interventions: relaxation, reflection, stress management, dietary control.

Comparator: managed by conventional methods i.e. risk factor control and American Heart Association step I diet.

Co-interventions: none described.

\begin{tabular}{ll}
\hline Outcomes & $\begin{array}{l}\text { total mortality; CABG; PCI. } \\
\text { Assessments are baseline and 1 yr. }\end{array}$ \\
\hline Source of funding & $\begin{array}{l}\text { This study was supported in part by a grant from the Central Research Institute of Yoga, Ministry of } \\
\text { Health, Government of India. }\end{array}$ \\
\hline Conflicts of interest & NR \\
\hline Notes & Authors' judgement Support for judgement \\
\hline Risk of bias & Unclear risk "randomized" \\
\hline Bias & \\
\hline $\begin{array}{l}\text { Random sequence genera- } \\
\text { tion (selection bias) }\end{array}$ & \\
\hline \hline
\end{tabular}


Manchanda 2000 (Continued)

\begin{tabular}{lll}
$\begin{array}{l}\text { Allocation concealment } \\
\text { (selection bias) }\end{array}$ & Unclear risk & Not reported. \\
\hline $\begin{array}{l}\text { Blinding of outcome as- } \\
\text { sessment (detection bias) } \\
\text { All outcomes }\end{array}$ & Low risk & $\begin{array}{l}\text { "Two independent observers who were blinded to group allocation analysed } \\
\text { all ateriograms." }\end{array}$ \\
\hline
\end{tabular}

\begin{tabular}{lll}
\hline $\begin{array}{l}\text { Incomplete outcome data } \\
\text { (attrition bias) } \\
\text { All outcomes }\end{array}$ & Low risk & All patients accounted for. \\
\hline $\begin{array}{l}\text { Selective reporting (re- } \\
\text { porting bias) }\end{array}$ & High risk & $\begin{array}{l}\text { While patients were given a clinical exam and clinical investiatigations every } \\
\text { month, only the results at 1 year are presented. }\end{array}$ \\
\hline $\begin{array}{l}\text { Groups balanced at base- } \\
\text { line }\end{array}$ & High risk & Patients in the yoga group had significantly more anginal episodes per week. \\
\hline $\begin{array}{l}\text { Intention-to-treat analysis } \\
\text { conducted }\end{array}$ & Unclear risk & Unclear. \\
\hline $\begin{array}{l}\text { Groups received same } \\
\text { treatment (apart from the } \\
\text { intervention) }\end{array}$ & High risk & $\begin{array}{l}\text { "The active group was treated with a user-friendly program consisting of yoga, } \\
\text { control of risk factors, diet control and moderate aerobic exercise. The con- } \\
\text { trol group was managed by conventional methods i.e. risk factor control and } \\
\text { American Heart Association step I diet." }\end{array}$ \\
\hline
\end{tabular}

Marchionni 2003

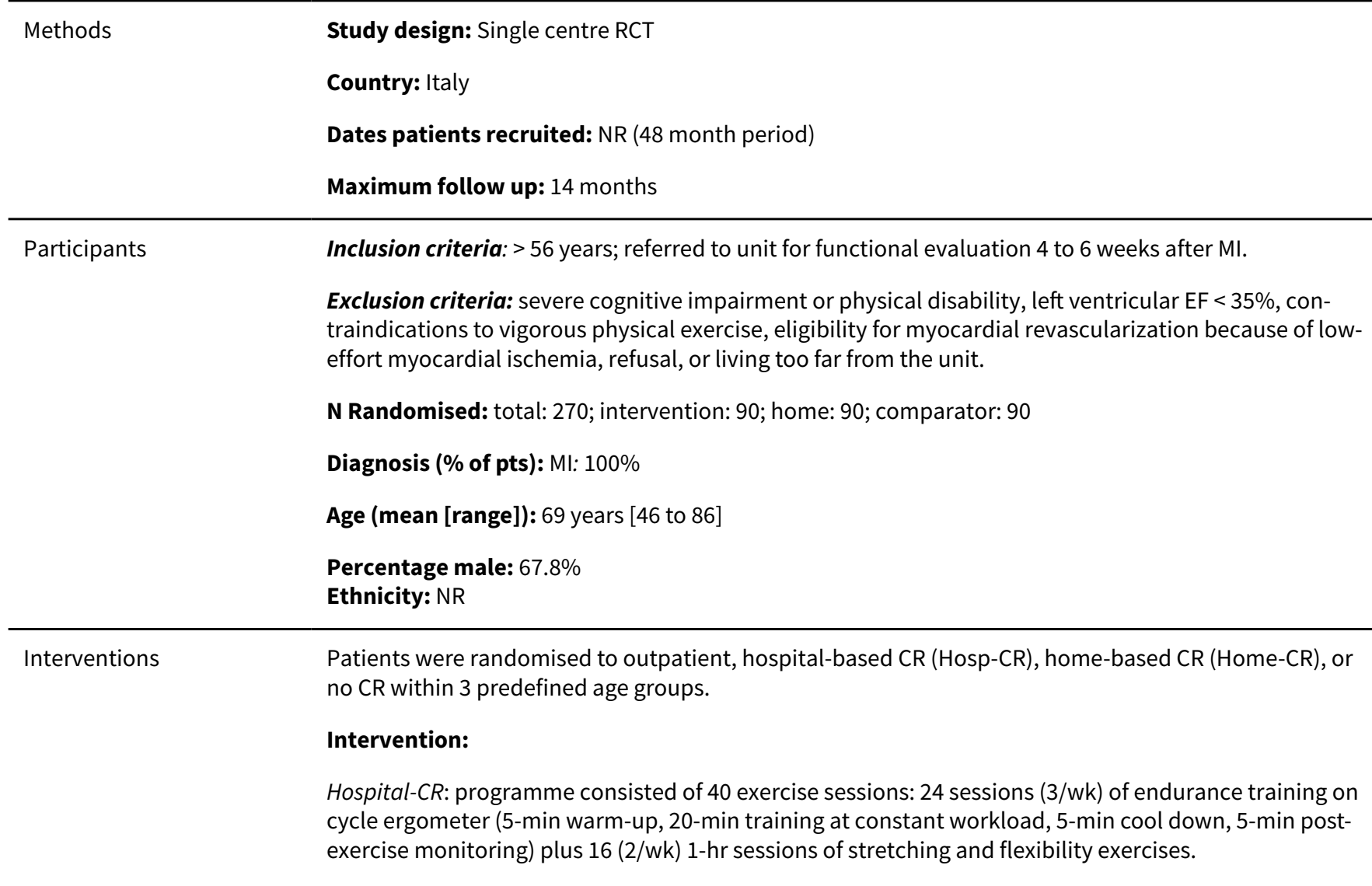


Marchionni 2003 (Continued)

Home-CR: 4-8 supervised instruction sessions in CR unit, where taught how to perform training at home; then patients received exercise prescription similar to Hosp-CR group.

Components:

Setting: centre or home.

Aerobic exercise:

Modality: cycle ergometer.

Length of session: 35 min edurance training; 1 hour stretching and flexibility exercises.

Frequency: 3 per week of endurance training; 2 per week of stretching and flexibility exercises.

Intensity: $70 \%$ to $85 \%$ of heart rate.

\section{Resistance training included? No.}

Total duration: 8 weeks.

Co-interventions: Patients received cardiovascular risk factor management counselling twice per week and were invited to join a monthly support group together with family members.

Comparator: Patients randomised to no CR were referred back to their family physicians.

Co-interventions: Patients received a single structured education session on cardiovascular risk factor management.

Outcomes HRQL at month 2, 8 and 14 .

Costs over study duration.

Source of funding National Research Council (CNR), the University of Florence, and the Regional Government of Tuscany, Italy.

Conflicts of interest NR

\section{Notes}

\section{Risk of bias}

\begin{tabular}{lll}
\hline Bias & Authors' judgement & Support for judgement \\
\hline $\begin{array}{l}\text { Random sequence genera- } \\
\text { tion (selection bias) }\end{array}$ & Unclear risk & Not reported. \\
\hline $\begin{array}{l}\text { Allocation concealment } \\
\text { (selection bias) }\end{array}$ & Unclear risk & Not reported. \\
\hline $\begin{array}{l}\text { Blinding of outcome as- } \\
\text { sessment (detection bias) } \\
\text { All outcomes }\end{array}$ & Low risk & "Testing personnel were blinded to patient assignment." \\
\hline $\begin{array}{l}\text { Incomplete outcome data } \\
\text { (attrition bias) } \\
\text { All outcomes }\end{array}$ & High risk & $\begin{array}{l}38 \text { (14.1\%) dropped out; clinical event data for these patients not reported per } \\
\text { treatment group. }\end{array}$ \\
\hline $\begin{array}{l}\text { Selective reporting (re- } \\
\text { porting bias) }\end{array}$ & Low risk & $\begin{array}{l}\text { Changes in all outcomes reported for all time points (although absolute values } \\
\text { not given). }\end{array}$ \\
\hline
\end{tabular}


Marchionni 2003 (Continued)

Groups balanced at base- Low risk In the entire series and within each age stratum, baseline sociodemographic line and clinical characteristics were similar across the 3 arms of the trial (analysis not shown).
No...but.... "we performed a sensitivity analysis comparing results obtained with and without replacement of missing data with data obtained with the expectation-maximization imputation method. Because the 2 analyses provided similar results, which were also similar with missing data substituted with data estimated in a worst-case scenario, only the data from patients who completed the study are presented"

\section{Groups received same Low risk} treatment (apart from the intervention)
"Within each age group, participants were randomized to Hosp-CR, Home-CR, or no CR." "Patients in Hosp-CR group received cardiovascular risk factor management counseling twice per week and were invited to join a monthly support group together with family members."

"Patients randomized to Home-CR participated in 4 to 8 supervised instruction sessions in the CR unit, where they were taught necessary precautions and how to perform their training at home. Patients received cardiovascular risk factor management counseling at each in-hospital session and were invited to join a monthly family oriented support group.....and an exercise prescription similar to that of the Hosp-CR group"

Patients randomized to no $\mathrm{CR}$ attended a single structured education session on

cardiovascular risk factor management with no exercise prescription and were referred back to their family physicians.

Dates patients recruited: NR (2 year enrolment period)

Maximum follow up: 10 years

Participants

Inclusion criteria: Male patients diagnosed with AMI and admitted to the coronary care unit; age $<65$ years; low risk (hospital course without complications, absence of signs of myocardial ischemia, functional capacity $>7$ metabolic equivalent time [MET], ejection fraction $>50 \%$, and absence of severe ventricular arrhythmias).

Exclusion criteria: none described

N Randomised: total: 180; intervention: 90; comparator: 90

Diagnosis (\% of pts):

AMI: $100 \%$

Anterior: intervention: $40.0 \%$; comparator: $48.3 \%$

Inferior/posterior: intervention: $48.3 \%$; comparator: $46.3 \%$

Non-Q wave: intervention: 11.6\%; comparator: $5.3 \%$

Age (mean \pm SD): intervention: $50.3 \pm 6$; comparator: $52.6 \pm 9$ 
Maroto 2005 (Continued)

Percentage male: intervention: 100\%; comparator: $100 \%$

Ethnicity: NR

Interventions

\section{Intervention:}

Multidisciplinary CR programme, consisting of:

- three months supervised, individualised physical training;

- psychological programme including behavior modification techniques, group therapy, and relaxation sessions;

- educational programme on modifying lifestyle and controlling coronary risk factors;

- return to work counselling.

Supervised training was complemented by progressively increasing daily walks of 1 hour in duration, when patients tried to maintain the heart rate achieved during training. Walks were undertaken by patients individually

and were unsupervised.

Components: exercise plus psychological plus education plus return to work counselling.

Setting: individualised supervised programme in hospital gym.

\section{Aerobic exercise:}

Modality: physiotherapy and aerobic training on mats or an exercise bicycle.

Length of session: 1-hour sessions.

Frequency: 3 times per week.

Intensity: $75-85 \%$ max HR.

Resistance training included? No.

Total duration: 3 months.

\section{Co-interventions:}

Participants received a psychological programme including behaviour modification techniques, group therapy, and relaxation sessions, an educational programme on modifying lifestyle and controlling coronary risk factors, and return to work counselling.

Comparator: Participants received conventional treatment.

Co-interventions: None described.

Outcomes Mortality, MI

\begin{tabular}{ll}
\hline Source of funding & NR \\
\hline Conflicts of interest & NR \\
\hline
\end{tabular}

Notes

\section{Risk of bias}

\begin{tabular}{lll}
\hline Bias & Authors' judgement & Support for judgement \\
\hline $\begin{array}{l}\text { Random sequence genera- } \\
\text { tion (selection bias) }\end{array}$ & Unclear risk & "The 180 patients were randomized into 2 groups".
\end{tabular}


Maroto 2005 (Continued)

Allocation concealment $\quad$ Unclear risk $\quad$ Allocation concealment is not described.
(selection bias)

Blinding of outcome as-

Unclear risk

Blinding not described.

sessment (detection bias)

All outcomes

\begin{tabular}{ll}
\hline $\begin{array}{l}\text { Incomplete outcome data } \\
\text { (attrition bias) }\end{array}$ & Low risk \\
All outcomes & $\begin{array}{l}7 / 90 \text { lost to sample in intervention group and 4/90 lost to sample in control } \\
\text { group. }\end{array}$
\end{tabular}

\begin{tabular}{lll}
\hline $\begin{array}{l}\text { Selective reporting (re- } \\
\text { porting bias) }\end{array}$ & Low risk & All outcomes described in methods section are reported at all time points. \\
\hline $\begin{array}{l}\text { Groups balanced at base- } \\
\text { line }\end{array}$ & Low risk & Baseline patient characteristics were similar in both groups. \\
\hline $\begin{array}{l}\text { Intention-to-treat analysis } \\
\text { conducted }\end{array}$ & High risk & ITT not described and no details of how missing data was handled is given. \\
\hline $\begin{array}{l}\text { Groups received same } \\
\text { treatment (apart from the } \\
\text { intervention) }\end{array}$ & High risk & No "N" given in Table 4. \\
\hline
\end{tabular}

Miller 1984

Methods Study design: RCT; patients randomised 3 weeks post-MI

Country: USA

Dates patients recruited: NR

Maximum follow up: 6 months

Participants Inclusion criteria: Men $<70 \mathrm{yrs}$ with MI documented by the combination of characteristic elevation of serum creatine kinase or oxaloacetic transaminase, a history of prolonged chest pain consistent with myocardial infarction, and the appearance of new $\mathrm{Q}$ waves or evolutionary ST segment changes.

Exclusion criteria: Conditions that precluded symptom-limited treadmill testing 3 weeks after infarction. e.g. congestive heart failure, unstable angina pectoris, valvular heart disease, atrial fibrillation, bundle branch block, stroke, limiting orthopedic abnormalities, peripheral vascular disease, chronic obstructive pulmonary disease and obesity, a history of coronary artery bypass graft (CABG) surgery, reinfarction before testing, and intercurrent noncardiac illness.

N Randomised: total: 198; group 1: 66; group 2: 61; group 3: 34; comparator: 37

Diagnosis (\% of pts): MI: $100 \%$

Age (mean \pm SD): $52 \pm 9$

Percentage male: intervention: 100\%; comparator: $100 \%$ Ethnicity: NR

Interventions

Patients were randomly assigned to one of four exercise protocols:

- group 1: 8 to 26 weeks of training at home;

- group 2: training in a group programme; 
- group 3: treadmill testing at 3 weeks without subsequent training;

- control: treadmill testing for the first time at 26 weeks.

Regimens of home and group exercise training were designed to provide a similar intensity and duration of exercise training.

Intervention: home training.

Components: exercise.

Setting: home.

\section{Aerobic exercise:}

Modality: stationary cycling or walking.

Length of session: $30 \mathrm{~min}$.

Frequency: 5 days a week.

Intensity: week 3-11: $70 \%$ to $85 \%$ of the peak heart rate at week 3; Week $11-26: 70 \%$ to $85 \%$ of the peak heart rate at week 11 .

\section{Resistance training included? No.}

Total duration: 8 weeks or 26 weeks.

Co-interventions: none described.

Intervention: group training.

Components: exercise.

Setting: supervised in centre.

\section{Aerobic exercise:}

Modality: walking or jogging.

Length of session: 1 hour.

Frequency: 3 times a week.

Intensity: Patients regulated their training intensity by palpation of the radial or carotid pulse during the first $10 \mathrm{sec}$ after brief cessation of walking or jogging.

\section{Resistance training included? No.}

Total duration: 8 weeks or 26 weeks.

Co-interventions: none described.

Comparator: usual care (treadmill testing for the first time at 26 weeks).

Co-interventions: none described.

Outcomes CHD mortality, non fatal MI and revascularisation.

Source of funding Supported by grant from the NHLBI, Bethesda, and by a grant from the PepsiCo Foundation, Purchase, NY.

Conflicts of interest
NR 
Miller 1984 (Continued)

\section{Risk of bias}

\begin{tabular}{|c|c|c|}
\hline Bias & Authors' judgement & Support for judgement \\
\hline $\begin{array}{l}\text { Random sequence genera- } \\
\text { tion (selection bias) }\end{array}$ & Unclear risk & Not reported. \\
\hline $\begin{array}{l}\text { Allocation concealment } \\
\text { (selection bias) }\end{array}$ & Unclear risk & Not reported. \\
\hline $\begin{array}{l}\text { Blinding of outcome as- } \\
\text { sessment (detection bias) } \\
\text { All outcomes }\end{array}$ & Unclear risk & Blinding not described. \\
\hline $\begin{array}{l}\text { Incomplete outcome data } \\
\text { (attrition bias) } \\
\text { All outcomes }\end{array}$ & High risk & $5 \%$ lost to follow up, no description of withdrawals or dropouts. \\
\hline $\begin{array}{l}\text { Selective reporting (re- } \\
\text { porting bias) }\end{array}$ & Low risk & All outcomes reported for all time points. \\
\hline $\begin{array}{l}\text { Groups balanced at base- } \\
\text { line }\end{array}$ & Low risk & $\begin{array}{l}\text { "Demographic and medical characteristics were not significantly different be- } \\
\text { tween } \\
\text { groups." No data given. }\end{array}$ \\
\hline $\begin{array}{l}\text { Intention-to-treat analysis } \\
\text { conducted }\end{array}$ & High risk & No. \\
\hline $\begin{array}{l}\text { Groups received same } \\
\text { treatment (apart from the } \\
\text { intervention) }\end{array}$ & Low risk & Intervention included exercise only. \\
\hline
\end{tabular}

\section{Munk 2009}

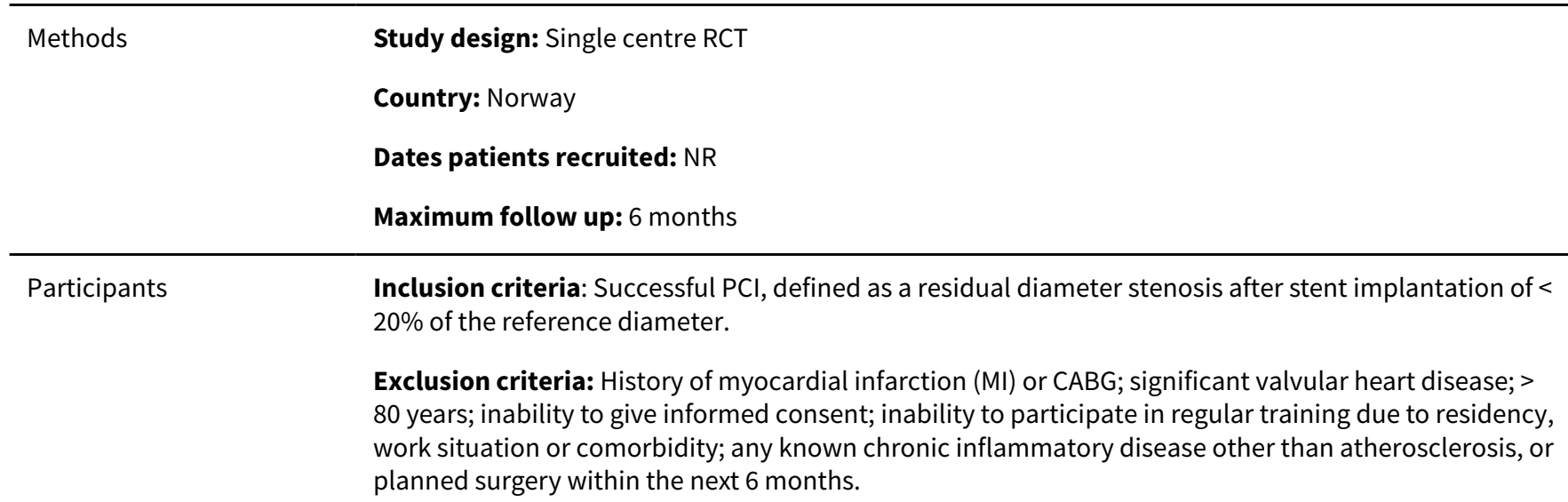

N Randomised: total: 40; intervention: 20; comparator: 20

Diagnosis ( $\%$ of pts):

Stable angina, post $\mathrm{PCl}$ intervention: $85 \%$; comparator: $95 \%$

Unstable angina, post PCl: intervention: 15\%; comparator: 5\% 
Munk 2009 (Continued)

Age (mean \pm SD): intervention: $57 \pm 14$; comparator: $61 \pm 10$

Percentage male: Total: 21\%; intervention: $18 \%$; comparator: $25 \%$

Ethnicity: NR

Interventions

Intervention: Starting $11 \pm 4$ days after $\mathrm{PCl}$,the training model included 10 min warm-up at $60 \%$ to $70 \%$ of max HR, followed by 4 min intervals at $80 \%$ to $90 \%$ of max HR, when patients were riding an ergometric bicycle or were running. Intervals were interrupted by 3 minutes of active recovery at $60 \%$ to $70 \%$ of maximal heart rate. Afterwards, there was $5 \mathrm{~min}$ cool-down, $10 \mathrm{~min}$ of abdominal and spine resistance exercises, and 5 min of stretching and relaxing. The training sessions were monitored with individual pulse watches allowing the patient to achieve the target heart rate.

Components: exercise only.

Setting: centre-based supervised training in groups of 10 .

\section{Aerobic exercise:}

Modality: ergometric bicycle or running.

Length of session: 1 hour.

Frequency: 3 times a week.

Intensity: $60-70 \%$ max HR.

Resistance training included? Spine \& abdominal resistance exercises.

Total duration: 6 months.

Co-interventions: None described.

Comparator: Participants received usual care (not described), including drug therapy of clopidogrel, aspirin and statins.

Co-interventions: None described.

Outcomes Mortality, MI, and revascularisations.

Source of funding Norwegian Health Association, Oslo, Norway, and Stavanger University Hospital.

Conflicts of interest $\quad$ NR in this paper, but none declared in Munk 2011.

Notes

\section{Risk of bias}

\begin{tabular}{|c|c|c|}
\hline Bias & Authors' judgement & Support for judgement \\
\hline $\begin{array}{l}\text { Random sequence genera- } \\
\text { tion (selection bias) }\end{array}$ & Low risk & $\begin{array}{l}\text { "The order of treatments within the block was randomly permuted by a com- } \\
\text { puter-generated sequence." }\end{array}$ \\
\hline $\begin{array}{l}\text { Allocation concealment } \\
\text { (selection bias) }\end{array}$ & Low risk & $\begin{array}{l}\text { "The investigator, who recruited patients into the trial, was unaware of the } \\
\text { group to which a participant was allocated." }\end{array}$ \\
\hline $\begin{array}{l}\text { Blinding of outcome as- } \\
\text { sessment (detection bias) } \\
\text { All outcomes }\end{array}$ & Low risk & $\begin{array}{l}\text { "All scans were analysed twice with EchoPACtm (GE Vingmed Ultrasound) by } \\
\text { two blinded investigators. Two experienced cardiologists independently inter- } \\
\text { preted the images in a blinded manner." However, not clear if blinded for clini- } \\
\text { cal events and exercise capacity. }\end{array}$ \\
\hline $\begin{array}{l}\text { Incomplete outcome data } \\
\text { (attrition bias) }\end{array}$ & Low risk & "No patient was lost to follow up." \\
\hline
\end{tabular}


Munk 2009 (Continued)

All outcomes

Selective reporting (re- Low risk $\quad$ All outcomes described in methods were reported at all time points.
porting bias)

\begin{tabular}{ll}
\hline $\begin{array}{l}\text { Groups balanced at base- } \\
\text { line }\end{array}$ & "Tow risk \\
& medical treatment, or angiographic or procedural characteristics between the \\
& 2 groups."
\end{tabular}

\begin{tabular}{lll}
\hline $\begin{array}{l}\text { Intention-to-treat analysis } \\
\text { conducted }\end{array}$ & Unclear risk & $\begin{array}{l}\text { Not stated but no loss to follow up and groups appear to be analysed accord- } \\
\text { ing to original random allocation. }\end{array}$ \\
\hline $\begin{array}{l}\text { Groups received same } \\
\text { treatment (apart from the } \\
\text { intervention) }\end{array}$ & Low risk & $\begin{array}{l}\text { "All patients received Aspirin, Clopidogrel and a statin during the study peri- } \\
\text { od." }\end{array}$ \\
\hline
\end{tabular}

Mutwalli 2012

Study design: Single centre RCT
Country: Kingdom of Saudi Arabia
Dates patients recruited: 8 June 2008 to 3 January 2010
Maximum follow up: 6 months

Participants

Inclusion criteria: Patients admitted for coronary artery bypass graft (CABG) surgery.

Exclusion criteria: History of ejection fraction less than $30 \%$, poor mobility leading to difficulty in walking, chronic atrial fibrillation, repeat CABG or implantable pacemaker were excluded from the study.

N Randomised: total: 49; intervention: 28; comparator:21

Diagnosis (\% of pts): post-CABG: $100 \%$

Age (years): intervention: 56.75 (range 53.6 - 59.8); comparator: 57.22 (range 54.4 - 60.2)

Percentage male: intervention: 100\%; comparator: $100 \%$

Ethnicity: NR

Interventions

Intervention: Whilst in the cardiac ward, the participants walked daily for 30 minutes. Additionally, before discharge, the participants climbed one flight of stairs and were then asked to walk unaided at a comfortable pace 30 minutes per day until they completed the 6-month home-based CR programme.

Components: exercise plus education.

Setting: at home, unsupervised with telephone support.

\section{Aerobic exercise:}

Modality: walking.

Length of session: 30 minutes.

Frequency: daily.

Intensity: NR

\section{Resistance training included? No.}


Total duration: 6 months.

Co-interventions: Patients received pre-CABG, immediately post-CABG, and home-based CR program, including education, food management education and a one-hour group workshop which included advice on modifiable and non-modifiable risk factors, change of lifestyle, active life, stress, and then discussed participant's problems and feelings during the past 2-months. This group workshop was repeated 4-months and 6-months after hospital discharge.

Comparator: The control group received standard hospital care, including regular advice from doctors and followed usual hospital instructions. This did not include a rehabilitation programme or telephone calls by the study authors.

Co-interventions: None described.

\begin{tabular}{ll}
\hline Outcomes & Mortality, MI, hospitalisation and HRQL. \\
\hline Source of funding & "Work was not supported or funded by any drug company." \\
\hline Conflicts of interest & "Authors have no conflict of interests." \\
\hline Notes &
\end{tabular}

\section{Risk of bias}

\begin{tabular}{|c|c|c|}
\hline Bias & Authors' judgement & Support for judgement \\
\hline $\begin{array}{l}\text { Random sequence genera- } \\
\text { tion (selection bias) }\end{array}$ & Unclear risk & $\begin{array}{l}\text { "Patients who consented to participate in the study, were randomly as- } \\
\text { signed...." }\end{array}$ \\
\hline $\begin{array}{l}\text { Allocation concealment } \\
\text { (selection bias) }\end{array}$ & Unclear risk & Allocation concealment not described \\
\hline $\begin{array}{l}\text { Blinding of outcome as- } \\
\text { sessment (detection bias) } \\
\text { All outcomes }\end{array}$ & Unclear risk & Blinding not described \\
\hline $\begin{array}{l}\text { Incomplete outcome data } \\
\text { (attrition bias) } \\
\text { All outcomes }\end{array}$ & High risk & $\begin{array}{l}7 / 50 \text { pts }(14 \%) \text { lost to follow up: one from control group died }(1 / 22,5 \%) \text { and } 6 \\
\text { from the intervention group }(6 / 28,21 \%) \text { could not complete the study require- } \\
\text { ments. }\end{array}$ \\
\hline $\begin{array}{l}\text { Selective reporting (re- } \\
\text { porting bias) }\end{array}$ & Low risk & All outcomes described in methods are reported at all time points. \\
\hline $\begin{array}{l}\text { Groups balanced at base- } \\
\text { line }\end{array}$ & Low risk & $\begin{array}{l}\text { "there were no significant differences between the } 2 \text { groups in age and risk fac- } \\
\text { tors at baseline } \\
(p>0.05) . "\end{array}$ \\
\hline $\begin{array}{l}\text { Intention-to-treat analysis } \\
\text { conducted }\end{array}$ & High risk & $\begin{array}{l}\text { Intention-to-treat analysis is not stated, and Table } 4 \text { suggests this was not con- } \\
\text { ducted. There are no details of how missing data was handled. }\end{array}$ \\
\hline $\begin{array}{l}\text { Groups received same } \\
\text { treatment (apart from the } \\
\text { intervention) }\end{array}$ & Low risk & $\begin{array}{l}\text { "This (control) group followed the usual hospital care and did not receive reha- } \\
\text { bilitation programme or telephone calls by the authors". }\end{array}$ \\
\hline
\end{tabular}


Oerkild 2012

Methods
Study design: Single centre RCT

Country: Denmark

Dates patients recruited: January 2007 to July 2008.

Maximum follow up: 12 months; mortality data after 5.5 years (mean follow-up $4 \frac{1}{2}$ years).
Inclusion criteria: Patients $\geq 65$ years with a recent coronary event defined as acute myocardial infarction (MI), percutaneous transluminal coronary intervention (PCI) or coronary artery bypass graft (CABG) and who declined participation in centre-based CR.

Exclusion criteria: Mental disorders (dementia), social disorders (severe alcoholism and drug abuse), living in a nursing home, language barriers or use of wheelchair.

N Randomised: total: 40; intervention: 19; comparator: 21

Diagnosis (\% of pts):

Previous MI: intervention: 31.7; comparator: 38.1

Previous PCl: intervention: 21.1; comparator: 23.8

Previous CABG: intervention: 0; comparator: 9.5

Heart failure LVEF $\leq 45 \%$ : intervention: 50.0; comparator: 42.9

\section{Event prior to entry into the study}

Post-MI without invasive procedure: intervention:0; comparator: 19.1

Post-PCl: intervention: 84.2; comparator: 66.7

Post-CABG: intervention:15.8; comparator: 14.3

Age (mean \pm SD): intervention:77.3 \pm 6.0 ; comparator: $76.5 \pm 7.7$

Percentage male: intervention: $63.2 \%$; comparator: $52.3 \%$

Ethnicity: NR

Interventions
Intervention: Individualised exercise programmes followed the international recommendations with 30 min exercise/day including 5-10 min warm up (e.g. slow walking) and $10 \mathrm{~min}$ cool-down at a frequency of 6 days/week at an intensity of 11-13 on the Borg scale. For very disabled patients, the exercise programmes were of shorter duration but then repeated several times a day. At 4 and 5 months, a telephone call was made by the cardiologist to encourage continuous exercising and to answer any medical questions.

Components: exercise plus risk factor management.

Setting: unsupervised individualised programme at home, with telephone support.

\section{Aerobic exercise:}

Modality: individualised.

Length of session: $30 \mathrm{~min}$.

Frequency: 6 days a week.

Intensity: $11-13$ on the Borg scale.

Resistance training included? no.

Total duration: 12 months. 
Oerkild 2012 (Continued)

Co-interventions: The patients consulted a cardiologist at baseline and after 3, 6 and 12 months, regarding risk factor intervention and medical adjustment. All patients were offered dietary counselling and, if required, smoking cessation.

Comparator: Patients received usual care. They received consultation with a cardiologist, and telephone calls at 4 and 5 months. They were not offered exercise education or dietary counselling.

Co-interventions: Patients were offered risk factor intervention and medical adjustment by a cardiologist at baseline and after 3, 6 and 12 months.

\begin{tabular}{ll}
\hline Outcomes & Mortality, HRQL. \\
\hline Source of funding & Velux Foundations. \\
\hline Conflicts of interest & None. \\
\hline Notes & \\
\hline
\end{tabular}

\section{Risk of bias}

\begin{tabular}{|c|c|c|}
\hline Bias & Authors' judgement & Support for judgement \\
\hline $\begin{array}{l}\text { Random sequence genera- } \\
\text { tion (selection bias) }\end{array}$ & Low risk & $\begin{array}{l}\text { "Patients were randomised in alternated block sizes of 4-6 using comput- } \\
\text { er-generated randomly permuted blocks". }\end{array}$ \\
\hline $\begin{array}{l}\text { Allocation concealment } \\
\text { (selection bias) }\end{array}$ & Low risk & "An impartial person, not related to the study, randomised the patients". \\
\hline $\begin{array}{l}\text { Blinding of outcome as- } \\
\text { sessment (detection bias) } \\
\text { All outcomes }\end{array}$ & Unclear risk & $\begin{array}{l}\text { "Because of the nature of the intervention, concealment of randomisation was } \\
\text { not feasible with regard to both patients and researcher". It is not clear if out- } \\
\text { come measures are blinded. }\end{array}$ \\
\hline $\begin{array}{l}\text { Incomplete outcome data } \\
\text { (attrition bias) } \\
\text { All outcomes }\end{array}$ & Low risk & $\begin{array}{l}\text { "A total of nine patients died during a mean follow-up of } 4.5 \text { years (usual care } \\
\text { group } n=5 \text { and home group } n=4 \text { ). There was no loss to follow-up." }\end{array}$ \\
\hline $\begin{array}{l}\text { Selective reporting (re- } \\
\text { porting bias) }\end{array}$ & High risk & $\begin{array}{l}\text { Although the methods state that outcomes were measured at 3, } 6 \text { and } 12 \\
\text { months, only exercise capacity is reported at } 6 \text { months. }\end{array}$ \\
\hline $\begin{array}{l}\text { Groups balanced at base- } \\
\text { line }\end{array}$ & Low risk & Table 1 shows groups are similar. \\
\hline $\begin{array}{l}\text { Intention-to-treat analysis } \\
\text { conducted }\end{array}$ & Low risk & "Data were analysed by intention to treat". \\
\hline $\begin{array}{l}\text { Groups received same } \\
\text { treatment (apart from the } \\
\text { intervention) }\end{array}$ & Low risk & $\begin{array}{l}\text { "Patients were not offered exercise education or dietary counselling but, as for } \\
\text { the home group, offered risk factor intervention and medical adjustment by a } \\
\text { cardiologist at baseline and after 3, } 6 \text { and } 12 \text { months". }\end{array}$ \\
\hline
\end{tabular}

\section{Oldridge 1991}

$\begin{array}{ll}\text { Methods } & \text { Study design: Multicentre RCT (6 sites) } \\ \text { Country: Canada }\end{array}$

Dates patients recruited: NR 
Oldridge 1991 (Continued)

\section{Maximum follow up: 1 year}

Participants

Inclusion criteria: Diagnosis of AMI and scoring > 5 on the short form of the Beck Depression Inventory or $>43$ on the Spielberger State Anxiety Inventory or $>42$ on the Spielberger Trait Anxiety Inventory while still in hospital.

Exclusion criteria: Residence $>30$ miles from the Health Sciences Centre; inability to exercise due to uncontrolled dysrhythmias, heart failure or unstable angina; neurologic, orthopedic, peripheral vascular or respiratory disease; and inability to complete the quality of life questionnaires due to cognitive or language problems.

N Randomised: total: 201; intervention: 99; comparator: 102

Diagnosis (\% of pts): MI: $100 \%$

Age (mean \pm SD): intervention: $52.9 \pm 9.5$; comparator: $52.7 \pm 9.5$

Percentage male: intervention: $88 \%$; comparator: $90 \%$

Ethnicity: NR

Interventions

Intervention: Participants attended 50 min exercise sessions twice a week for 8 consecutive weeks. These sessions were held in a hospital gymnasium under the direct supervision of a cardiologist and qualified exercise specialists. There was a 10 min group warm-up at the beginning of each session; stationary cycle ergometry, treadmill walking and arm ergometry followed for 20 to 30 minutes. A cooldown, involving low-intensity activities, concluded the exercise session.

Components: exercise and behavioural counselling.

Setting: centre.

\section{Aerobic exercise:}

Modality: stationary cycle ergometry, treadmill walking and arm ergometry.

Length of session: $50 \mathrm{~min}$.

Frequency: twice a week.

Intensity: initially on $65 \%$ of the maximal heart rate.

Resistance training included? No.

Total duration: 8 weeks.

Co-interventions: The cognitive behavioural group intervention, facilitated by group leaders without formal training in counselling, consisted of 8 sessions of 90 minutes complemented by progressive relaxation training at the end of the session. Both patient and spouse were invited to attend the group sessions.

Comparator: conventional care.

Co-interventions: none described.

\begin{tabular}{ll}
\hline Outcomes & Mortality \\
& Health-related quality of life: QOLMI time trade-off. Cost data reported in Oldridge 1993 \\
\hline Source of funding & $\begin{array}{l}\text { This work was supported by the National Health Research and Development Programme, Health and } \\
\text { Welfare, Canada }\end{array}$
\end{tabular}

Conflicts of interest NR 
Oldridge 1991 (Continued)

Risk of bias

\begin{tabular}{|c|c|c|}
\hline Bias & Authors' judgement & Support for judgement \\
\hline $\begin{array}{l}\text { Random sequence genera- } \\
\text { tion (selection bias) }\end{array}$ & Unclear risk & "randomized" \\
\hline $\begin{array}{l}\text { Allocation concealment } \\
\text { (selection bias) }\end{array}$ & Unclear risk & Not reported. \\
\hline $\begin{array}{l}\text { Blinding of outcome as- } \\
\text { sessment (detection bias) } \\
\text { All outcomes }\end{array}$ & High risk & "the investigators were not blinded to allocation" \\
\hline $\begin{array}{l}\text { Incomplete outcome data } \\
\text { (attrition bias) } \\
\text { All outcomes }\end{array}$ & High risk & $\begin{array}{l}\text { For the primary outcome -HRQL- } 9 \% \text { lost to follow up, no description of with- } \\
\text { drawals or dropouts. }\end{array}$ \\
\hline $\begin{array}{l}\text { Selective reporting (re- } \\
\text { porting bias) }\end{array}$ & Low risk & All outcomes were reported at all time points. \\
\hline $\begin{array}{l}\text { Groups balanced at base- } \\
\text { line }\end{array}$ & Low risk & $\begin{array}{l}\text { "Randomization was successful, in that patients allocated to rehabilitation } \\
\text { and conventional care groups were essentially comparable." }\end{array}$ \\
\hline $\begin{array}{l}\text { Intention-to-treat analysis } \\
\text { conducted }\end{array}$ & High risk & No. \\
\hline $\begin{array}{l}\text { Groups received same } \\
\text { treatment (apart from the } \\
\text { intervention) }\end{array}$ & High risk & $\begin{array}{l}\text { "Eligible patients were .... randomized to either community care (control) or } \\
\text { an experimental (treatment) group in which small groups of patients received } \\
\text { an exercise prescription and behavioural counselling." }\end{array}$ \\
\hline
\end{tabular}

Ornish 1990

\begin{tabular}{ll} 
Methods & Study design: Multicentre RCT (2 sites) \\
Country: US \\
Dates patients recruited: NR \\
Maximum follow up: 5 years \\
\hline Inclusion criteria: Age $35-75$ years, male or female; residence in the \\
two, or three vessel CAD (defined as any measurable coronary ather \\
bypassed coronary artery); LVEF > 25\% \\
Exclusion criteria: Other life-threatening illnesses; MI during the \\
ing streptokinase or alteplase; currently receiving lipid-lowering \\
N Randomised: total: 48 ; intervention: $28 ;$ comparator: 20 \\
Diagnosis (\% of pts): moderate to severe CAD: $100 \%$ \\
Age (mean \pm SD): Intervention: $56.1 \pm 7.5$; Comparator: $59.8 \pm 9.1$ \\
Percentage male: Intervention: $95 \%$; Comparator: $79 \%$ \\
Ethnicity: NR
\end{tabular}


Ornish 1990 (Continued)

Interventions

Intervention: The intervention began with a week-long residential retreat at a hotel to teach the lifestyle intervention to the experimental-group patients. Patients then attended regular group support meetings ( $4 \mathrm{~h}$ twice a week). Patients were individually prescribed exercise levels (typically walking) according to their baseline treadmill test results. Patients were asked to exercise for a minimum of $3 \mathrm{~h}$ per week and to spend a minimum of 30 min per session exercising within their target heart rates.

\section{Components:}

Setting: centre.

\section{Aerobic exercise:}

Modality: typically walking.

Length of session: minimum of $30 \mathrm{~min}$.

Frequency: up to 6 times a week.

Intensity: heart rate of $50-80 \%$.

Resistance training included? No.

Total duration: 1 year.

Co-interventions: stress management, low fat vegetarian diet, group psychosocial support.

Comparator: usual care.

Co-interventions: none described.

\begin{tabular}{|c|c|}
\hline Outcomes & $\begin{array}{l}\text { CHD mortality, non-fatal MI, revascularisation. } \\
\text { Assessment at baseline and after } 1 \text { year and } 5 \text { years. }\end{array}$ \\
\hline Source of funding & $\begin{array}{l}\text { National Heart, Lung, and Blood Institute of the National Institutes of Health, the Department of Health } \\
\text { Services of the State of California, Gerald D. Hines Interests, Houston Endowment Inc, the Henry J. } \\
\text { Kaiser Family Foundation. the John E. Fetzer Institute, Continental Airlines, the Enron Foundation, the } \\
\text { Nathan Cummings Foundation, the Pritzker Foundation, the First Boston Corporation, Quaker Oats Co., } \\
\text { Texas Commerce Bank, Corrine and David Gould, Pacific Presbyterian Medical Center Foundation, Gen- } \\
\text { eral Growth Companies, Arthur Andersen and Co. }\end{array}$ \\
\hline
\end{tabular}

\begin{tabular}{ll}
\hline Conflicts of interest & NR \\
\hline Notes & Intervention group had 91\% reduction in reported frequency of angina after 1 year and $72 \%$ after 5 \\
& years, comparator group had $186 \%$ increase in reported frequency of angina after 1 year and $36 \%$ de- \\
& crease after 5 years. \\
& Intervention group had $7.9 \%$ relative improvement in coronary artery diameter at 5 years, comparator \\
& group had 27.7\% relative worsening at 5 years.
\end{tabular}

\section{Risk of bias}

\begin{tabular}{lll}
\hline Bias & Authors' judgement & Support for judgement \\
\hline $\begin{array}{l}\text { Random sequence genera- } \\
\text { tion (selection bias) }\end{array}$ & Unclear risk & "randomly assigned" \\
\hline $\begin{array}{l}\text { Allocation concealment } \\
\text { (selection bias) }\end{array}$ & Unclear risk & Not reported. \\
\hline $\begin{array}{l}\text { Blinding of outcome as- } \\
\text { sessment (detection bias) }\end{array}$ & Low risk & $\begin{array}{l}\text { "Investigators carrying out out all medical tests remained unaware of both pa- } \\
\text { tient group assignment and the order of the tests". }\end{array}$
\end{tabular}


Ornish 1990 (Continued)

All outcomes

\begin{tabular}{|c|c|c|}
\hline $\begin{array}{l}\text { Incomplete outcome data } \\
\text { (attrition bias) }\end{array}$ & High risk & $\begin{array}{l}45 / 93(48 \%) \text { of randomised patients did not participate, no description of with- } \\
\text { drawals or dropouts. }\end{array}$ \\
\hline
\end{tabular}

All outcomes

drawals or dropouts.

\begin{tabular}{lll}
\hline $\begin{array}{l}\text { Selective reporting (re- } \\
\text { porting bias) }\end{array}$ & High risk & $\begin{array}{l}\text { Outcomes are only presented for } 1 \text { year, although blood tests were also taken } \\
\text { at } 6 \text { months. }\end{array}$ \\
\hline $\begin{array}{l}\text { Groups balanced at base- } \\
\text { line }\end{array}$ & Low risk & $\begin{array}{l}\text { "The experimental and control groups did not differ significantly in disease } \\
\text { severity at baseline". }\end{array}$ \\
\hline $\begin{array}{l}\text { Intention-to-treat analysis } \\
\text { conducted }\end{array}$ & High risk & No. \\
\hline $\begin{array}{l}\text { Groups received same } \\
\text { treatment (apart from the } \\
\text { intervention) }\end{array}$ & High risk & $\begin{array}{l}\text { "Patients were assigned to an experimental group or to a usual-care control } \\
\text { group. Experimental-group patients were prescribed a lifestyle programme } \\
\text { that included a low-fat vegetarian diet, moderate aerobic exercise, stress man- } \\
\text { agement training, stopping smoking, and group support. Control-group pa- } \\
\text { tients were not asked to make lifestyle changes, although they were free to do } \\
\text { so." }\end{array}$ \\
\hline
\end{tabular}

Reid 2012

\begin{tabular}{ll} 
Methods & Study design: Multicentre RCT (2 sites) \\
Country: Canada \\
Dates patients recruited: December 2004 to December 2007 \\
Maximum follow up: 12 months \\
\hline Participants & $\begin{array}{l}\text { Inclusion criteria: Admitted for acute coronary syndromes who: underwent successful percutaneous } \\
\text { coronary revascularization; were not planning on enrolling in CR; had internet access at home or work; } \\
\text { and were } 20 \text { to } 80 \text { years of age. }\end{array}$
\end{tabular}

Exclusion criteria: CABG; implantable cardioverter-defibrillator; NYHA Class III or IV heart failure; inability to speak and read English.

N Randomised: total: 223 ; intervention: 115; comparator: 108

Diagnosis (\% of pts):

AMI this admission: $29.1 \%$

$\mathrm{PCl}$ this admission: $98.2 \%$

First cardiac event: $64.6 \%$

Previous AMI: $18.8 \%$

Previous PCI: $27.4 \%$

Previous CABG: $9.0 \%$

Age (mean \pm SD): intervention: $56.7 \pm 9.0$; comparator: $56.0 \pm 9.0$

Percentage male: intervention: $82.6 \%$; comparator: $86.1 \%$

Ethnicity: NR

Interventions

Intervention: Participants were visited in hospital by an exercise specialist, who presented a personally tailored physical activity plan and instructions on how to access the CardioFit website. Following discharge, participants were asked to log their daily activity on the CardioFit website and complete a se- 
Reid 2012 (Continued)

ries of five online tutorials (at weeks 2, 4, 8, 14, and 20). Following each tutorial, a new physical activity plan was developed. Between tutorials, participants received emails from the exercise specialist providing motivational feedback on their progress.

Components: exercise plus psychological support.

Setting: home.

Aerobic exercise:

Modality: NR

Length of session: NR

Frequency: NR

Intensity: NR

Resistance training included? NR

Total duration: 20 weeks

Co-interventions: The CardioFit website and tutorials were designed to foster behavioural capability, self-efficacy, social support, and realistic outcome expectations. Tutorials were organised to engage self-control processes including exercise planning, goal setting, monitoring and self-regulation, and relapse prevention.

Comparator: physical activity guidance from their attending cardiologist and an education booklet.

Co-interventions: none described.

\begin{tabular}{ll}
\hline Outcomes & HRQL \\
\hline Source of funding & $\begin{array}{l}\text { Heart and Stroke Foundation of Ontario. Dr Reid was supported by a New Investigator Award from the } \\
\text { Heart and Stroke Foundation of Canada. Dr Blanchard is supported by the Canada Research Chairs pro- } \\
\text { gramme. }\end{array}$ \\
\hline
\end{tabular}

Conflicts of interest "The authors declare that there is no conflict of interests"

\section{Notes}

\section{Risk of bias}

\begin{tabular}{|c|c|c|}
\hline Bias & Authors' judgement & Support for judgement \\
\hline $\begin{array}{l}\text { Random sequence genera- } \\
\text { tion (selection bias) }\end{array}$ & Low risk & $\begin{array}{l}\text { "Participants were randomized ... using a random sequence that was comput- } \\
\text { er generated by a statistical consultant in blocks of } 4,8 \text {, and } 10 . "\end{array}$ \\
\hline $\begin{array}{l}\text { Allocation concealment } \\
\text { (selection bias) }\end{array}$ & Low risk & $\begin{array}{l}\text { "Sequences were generated for Ottawa and London and placed in sealed, } \\
\text { numbered envelopes to ensure that treatment allocation was concealed until } \\
\text { after baseline data collection. Research coordinators allocated the next avail- } \\
\text { able number on study entry (while the participant was still hospitalized)" }\end{array}$ \\
\hline $\begin{array}{l}\text { Blinding of outcome as- } \\
\text { sessment (detection bias) } \\
\text { All outcomes }\end{array}$ & Low risk & $\begin{array}{l}\text { "Research assistants, blinded to the participants' treatment allocation, con- } \\
\text { ducted follow-up assessments" }\end{array}$ \\
\hline $\begin{array}{l}\text { Incomplete outcome data } \\
\text { (attrition bias) } \\
\text { All outcomes }\end{array}$ & High risk & $\begin{array}{l}\text { Loss to follow-up was well reported but was high in both groups } 36 / 115 \text { [31\%] } \\
\text { and 33/108 [31\%] were lost to follow up from the Intervention and control } \\
\text { groups. }\end{array}$ \\
\hline
\end{tabular}


Reid 2012 (Continued)

Selective reporting (re- Low risk All outcomes described in the methods section are reported in results. porting bias)

Groups balanced at base- Low risk line
"The two study groups were similar when demographic and clinical factors and pre-hospitalization levels of leisure-time physical activity were compared."
Intention-to-treat analysis Low risk conducted
No intention-to-treat analysis was conducted, but missing outcome values were replaced by multiple imputations after confirming that the data were missing at random.

\begin{tabular}{|c|c|c|}
\hline $\begin{array}{l}\text { Groups received same } \\
\text { treatment (apart from the } \\
\text { intervention) }\end{array}$ & High risk & $\begin{array}{l}\text { "The intervention also focused on altering the key mediators of behaviour } \\
\text { change, including self-efficacy, social support and motivation". The compara- } \\
\text { tor group did not recieve this support. }\end{array}$ \\
\hline
\end{tabular}

Roman 1983

Methods

Study design: Single centre RCT

Country: Chile

Dates patients recruited: June 1973 to June 1981

Maximum follow up: 9 years

Participants

Inclusion criteria: Patients with transmural AMI.

Exclusion criteria: Severe arrhythmias persisting after the acute phase of AMI (frequent ventricular premature beats, grade iii-iv of the Lown classification, atrial flutter, partial or complete A_V block);great left-ventricular enlargement; left ventricular aneurysm; persistent cardiac failure; severe diastolic hypertension post-myocardial infarction angina.

N Randomised: total: 193; intervention: 93; comparator: 100

\section{Diagnosis (\% of pts):}

Transmural AMI: $100 \%$

Anterior wall infarction: $55 \%$

Posteroinferior infarction: $45 \%$

Age (mean \pm SD): intervention: $56.2 \pm 10.3$; comparator: $59.1 \pm 8.8$

Percentage male: intervention: 93.6\%; comparator: $87 \%$

Ethnicity: NR

Interventions

Intervention: Supervised physical training programme according to the guidelines reported by Zohman and Tobias. It was started with combined ergometric, calisthenic and walk-jogging exercise lasting $30 \mathrm{~min}$, three times a week. The intensity of the training was graded according to the target heart rate threshold, defined as $70 \%$ of maximal heart rate achieved by the patient in the former ergometric work test.

Components: exercise only.

Setting: centre.

\section{Aerobic exercise:}


Roman 1983 (Continued)

Modality: combined ergometric and walk-jogging exercise.

Length of session: $30 \mathrm{~min}$.

Frequency: three times a week.

Intensity: $70 \%$ of maximal heart rate.

Resistance training included? Calisthenics.

Total duration: average 42 months (range 6 to 108 months).

Co-interventions: none described.

Comparator: Control patients were medically treated according to the guidelines commonly used, namely, short- and long-lasting nitrites, ß-blockers or Ca antagonists (nifedipine).

Co-interventions: A small number (8 patients) were also treated with oral anticoagulants.

\begin{tabular}{ll}
\hline Outcomes & Mortality, MI and revascularisations. \\
\hline Source of funding & NR \\
\hline Conflicts of interest & NR \\
\hline
\end{tabular}

\section{Notes}

\section{Risk of bias}

\begin{tabular}{|c|c|c|}
\hline Bias & Authors' judgement & Support for judgement \\
\hline $\begin{array}{l}\text { Random sequence genera- } \\
\text { tion (selection bias) }\end{array}$ & Unclear risk & "Patients were randomly allocated..." \\
\hline $\begin{array}{l}\text { Allocation concealment } \\
\text { (selection bias) }\end{array}$ & Unclear risk & Allocation concealment not described. \\
\hline $\begin{array}{l}\text { Blinding of outcome as- } \\
\text { sessment (detection bias) } \\
\text { All outcomes }\end{array}$ & Unclear risk & Blinding not described. \\
\hline $\begin{array}{l}\text { Incomplete outcome data } \\
\text { (attrition bias) } \\
\text { All outcomes }\end{array}$ & Low risk & $\begin{array}{l}18 / 93(19.4 \%) \text { and } 18 / 100(18 \%) \text { withdrew or dropped out from intervention } \\
\text { and control groups over the 9-year period. }\end{array}$ \\
\hline $\begin{array}{l}\text { Selective reporting (re- } \\
\text { porting bias) }\end{array}$ & Low risk & $\begin{array}{l}\text { Mortality, morbidity and complications were recorded over the duration of the } \\
\text { study and are presented as rates. }\end{array}$ \\
\hline $\begin{array}{l}\text { Groups balanced at base- } \\
\text { line }\end{array}$ & Low risk & $\begin{array}{l}\text { "as can be observed, both groups were matched in all the characteristics that } \\
\text { could eventually alter the late prognosis of the disease" }\end{array}$ \\
\hline $\begin{array}{l}\text { Intention-to-treat analysis } \\
\text { conducted }\end{array}$ & Low risk & $\begin{array}{l}\text { ITT not described, and no details of how missing data is handled are given, but } \\
\text { groups appeared to be analysed according to original allocation. }\end{array}$ \\
\hline $\begin{array}{l}\text { Groups received same } \\
\text { treatment (apart from the } \\
\text { intervention) }\end{array}$ & Unclear risk & $\begin{array}{l}\text { Control patients were medically treated throughout, but it appears that CR pa- } \\
\text { tients were only prescribed medication on the appearance of unstable angina } \\
\text { or electrocardiographic ischemia. }\end{array}$ \\
\hline
\end{tabular}


Sandström 2005

Methods

Study design: Single centre RCT

Country: Sweden

Dates patients recruited: NR (recruited over a period of $2 \frac{1}{2}$ years)

Maximum follow up: 12 months

Participants

Inclusion criteria: Patients $>65$ years admitted following an acute coronary event. Patients had to perform a pre-discharge exercise test with a workload of $\geq 70$ watts in men and $\geq 50$ watts in women.

Exclusion criteria: Patients with neurological sequels, memory dysfunction such as dementia, orthopaedic disability, inability to speak or understand Swedish, or both, and a planned coronary intervention within 3 months.

N Randomised: total: 101; intervention: 50; comparator: 51

Diagnosis (\% of pts):

Angina pectoris: intervention: $20 \%$; comparator: $21 \%$

Previous AMI: intervention: 18\%; comparator: $11 \%$

Acute coronary event: intervention: 50\%; comparator: 51\%

Previous $\mathrm{PCl}$ : intervention: 7\%; comparator: 5\%

Previous CABG: intervention: 9\%; comparator: 9\%

(Not mutually exclusive numbers.)

Age (median): total: 71 years (range 64-84); intervention: 71 years (range 64-84); comparator: 71 years (range 65-83)

Percentage male: total $80.2 \%$; intervention: $82 \%$; comparator: $78.4 \%$

Ethnicity: NR

Intervention: 50 min aerobic group training programme three times a week for 3 months, with a voluntary 50 min step-down period once a week for another 3 months. The complete programme was supported by music, which guided the intensity of the performance during the session. The training sessions were followed by 10 min of relaxation, also supported by music.

Components: exercise only.

Setting: centre-based supervised group sessions.

\section{Aerobic exercise:}

Modality: aerobic exercises to music.

Length of session: $50 \mathrm{~min}$ with a voluntary $50 \mathrm{~min}$ step-down period once a week for another 3 months.

Frequency: 3 times a week.

Intensity: NR

Resistance training included? No.

Total duration: 3 months.

Co-interventions: none described.

Comparator: patients were recommended to take a daily walk at a comfortable speed, and to gradually increase the time, length and speed, and were encouraged to restart their prior physical activity as soon as they felt fit enough for this. 
Sandström 2005 (Continued)

Co-interventions: none described.

\begin{tabular}{|c|c|c|}
\hline Outcomes & \multicolumn{2}{|c|}{ HRQL and revascularisation } \\
\hline Source of funding & \multicolumn{2}{|l|}{ NR } \\
\hline Conflicts of interest & \multicolumn{2}{|l|}{ NR } \\
\hline \multicolumn{3}{|l|}{ Notes } \\
\hline \multicolumn{3}{|l|}{ Risk of bias } \\
\hline Bias & Authors' judgement & Support for judgement \\
\hline $\begin{array}{l}\text { Random sequence genera- } \\
\text { tion (selection bias) }\end{array}$ & Unclear risk & "....were randomly allocated into one of two groups:" \\
\hline $\begin{array}{l}\text { Allocation concealment } \\
\text { (selection bias) }\end{array}$ & Unclear risk & Allocation concealment was not described. \\
\hline $\begin{array}{l}\text { Blinding of outcome as- } \\
\text { sessment (detection bias) } \\
\text { All outcomes }\end{array}$ & Low risk & $\begin{array}{l}\text { "patients were evaluated ..... by an independent, blinded to group allocation, } \\
\text { researcher." }\end{array}$ \\
\hline $\begin{array}{l}\text { Incomplete outcome data } \\
\text { (attrition bias) } \\
\text { All outcomes }\end{array}$ & Low risk & There was no attrition - data was reported for all patients randomised. \\
\hline $\begin{array}{l}\text { Selective reporting (re- } \\
\text { porting bias) }\end{array}$ & Low risk & All outcomes mentioned in methods were reported at all time points. \\
\hline $\begin{array}{l}\text { Groups balanced at base- } \\
\text { line }\end{array}$ & Low risk & $\begin{array}{l}\text { "There were neither demographic nor medical differences between the two } \\
\text { groups at baseline." }\end{array}$ \\
\hline $\begin{array}{l}\text { Intention-to-treat analysis } \\
\text { conducted }\end{array}$ & Low risk & $\begin{array}{l}\text { ITT was not described, but results are reported for same number of patients } \\
\text { randomised to each group. }\end{array}$ \\
\hline $\begin{array}{l}\text { Groups received same } \\
\text { treatment (apart from the } \\
\text { intervention) }\end{array}$ & Low risk & $\begin{array}{l}\text { All patients received verbal and written information about the importance of } \\
\text { regular physical activity after an acute coronary event. They were recommend- } \\
\text { ed to take a daily walk at a comfortable speed, and to gradually increase the } \\
\text { time, length and speed. }\end{array}$ \\
\hline
\end{tabular}

Schuler 1992

Methods Study design: Single centre RCT. Participants randomised after routine angiography for angina.

Country: Germany

Dates patients recruited: NR

Maximum follow up: 6 years

Participants Inclusion criteria: Male, stable symptoms, willingness to participate in the study for at least 12 months, coronary artery stenoses well documented by angiography, and permanent residence within $25 \mathrm{~km}$ of the training facilities at Heidelberg. 
Exclusion criteria: Unstable angina pectoris, left main coronary artery stenosis $>25 \%$ luminal diameter reduction, severely depressed left ventricular function (ejection fraction $<35 \%$ ), significant valvular heart disease, insulin-dependent diabetes mellitus, primary hypercholesterolemia (type II hyperlipoproteinemia, low density lipoprotein $[\mathrm{LDL}]>210 \mathrm{mg} / \mathrm{dl}$ ), and occupational, orthopedic, and other conditions precluding regular participation in exercise sessions.

N Randomised: total: 113; intervention: 56; comparator: 57

Diagnosis (\% of pts): AMI: $66 \%$

Age (mean \pm SD): intervention: $52.8 \pm 5.8$; comparator: $54.2 \pm 7.7$

Percentage male: intervention: $100 \%$; comparator: $100 \%$

Ethnicity: NR

Intervention: Patients stayed on a metabolic ward during the initial 3 weeks, during which they were instructed how to lower the fat content of their regular diet. Patients were asked to exercise daily at home on a cycle ergometer for a minimum of 30 minutes close to their target heart rates, which were determined as $75 \%$

of the maximal heart rate during symptom-limited exercise. In addition, they were expected to participate in at least

two group training sessions of 60 minutes each week.

Components: exercise and education.

Setting: centre (group session) and unsupervised at home.

\section{Aerobic exercise:}

Modality: cycle ergometer.

Length of session: $30 \mathrm{~min}$ at home and $60 \mathrm{~min}$ group session.

Frequency: daily at home; twice a week at centre.

Intensity: $75 \%$ maximal HR.

Resistance training included? No.

Total duration: 12 months.

Co-interventions: Patients were on their regular antianginal medication, including,$\beta$-blocking agents.

Comparator: Patients spent 1 week on the metabolic ward, where they received identical instructions about the necessity of regular physical exercise and how to lower fat consumption. "Usual care" was rendered by their private physicians.

Co-interventions: They were asked not to take lipid-lowering medications.

\begin{tabular}{ll}
\hline Outcomes & Total and CHD mortality, non fatal MI, revascularisation. \\
\hline Source of funding & Bundesministerium fir Forschung und Technologie, Bonn, FRG. \\
\hline Conflicts of interest & NR \\
\hline Notes & $\begin{array}{l}\text { Exercise adherence in the first year was } 68 \%(39 \% \text { to } 92 \%), \text { over the next } 5 \text { years } 33 \%(3 \% \text { to } 89 \%) . \\
\text { Pts with regression of coronary atheroma attended exercise sessions significantly more often (54+/- } \\
24 \%) \text { than patients with no change }(20+/-24 \%) \text { or progression } 31+/-20 \%) .\end{array}$ \\
\hline
\end{tabular}

\section{Risk of bias}


Schuler 1992 (Continued)

Random sequence genera- Unclear risk $\quad$ Not reported.
tion (selection bias)

Allocation concealment Low risk "sealed envelopes"
(selection bias)

\begin{tabular}{|c|c|c|}
\hline $\begin{array}{l}\text { Blinding of outcome as- } \\
\text { sessment (detection bias) } \\
\text { All outcomes }\end{array}$ & Low risk & $\begin{array}{l}\text { "Evaluation of coronary angiograms was performed by two technicians blind- } \\
\text { ed to the sequence of films and the patient's identity or group assignment." }\end{array}$ \\
\hline
\end{tabular}

\begin{tabular}{lll}
\hline $\begin{array}{l}\text { Incomplete outcome data } \\
\text { (attrition bias) } \\
\text { All outcomes }\end{array}$ & High risk & \\
\hline $\begin{array}{l}\text { Selective reporting (re- } \\
\text { porting bias) }\end{array}$ & Low risk & All outcomes were reported at all time points. \\
\hline $\begin{array}{l}\text { Groups balanced at base- } \\
\text { line }\end{array}$ & Low risk & "No significant difference between groups was detected for any variable \\
\hline $\begin{array}{l}\text { Intention-to-treat analysis } \\
\text { conducted }\end{array}$ & High risk & (Mann-Whitney rank sum test, X2 analysis)." \\
\hline $\begin{array}{l}\text { Groups received same } \\
\text { treatment (apart from the } \\
\text { intervention) }\end{array}$ & Low risk & $\begin{array}{l}\text { No. } \\
\text { "Patients assigned to the intervention group stayed on a metabolic ward dur- } \\
\text { ing the initial } 3 \text { weeks of the program, during which they were instructed how } \\
\text { to lower the fat content of their regular diet...Patients assigned to the control } \\
\text { group spent } 1 \text { week on the metabolic ward, where they received identical in- } \\
\text { structions about the necessity of regular physical exercise and how to lower } \\
\text { fat consumption". }\end{array}$ \\
\hline
\end{tabular}

Seki 2003

\begin{tabular}{ll}
\hline Study design: Single centre RCT \\
Country: Japan \\
Dates patients recruited: NR \\
Maximum follow up: 6 months \\
\hline Inclusion criteria: Male patients; $>65$ years of age; with chronic CAD; referred at least 6 months after a \\
major coronary event, including acute MI, coronary artery bypass grafting or percutaneous balloon an- \\
gioplasty for acute coronary syndrome. \\
Exclusion criteria: none described. \\
N Randomised: total: $38 ;$ intervention: $20 ;$ comparator: 18 \\
Diagnosis (\% of pts): \\
Chronic CAD: $100 \%$ \\
MI: $55 \%$ \\
PCl: $39 \%$ \\
CABG: $39 \%$ \\
Age (mean \pm SD): intervention: $69.3 \pm 2.9 ;$ comparator: $70.1 \pm 3.7$ \\
Percentage male: intervention: $100 \% ;$ comparator: $100 \%$ \\
\hline
\end{tabular}


Seki 2003 (Continued)

\section{Ethnicity: NR}

Interventions

Intervention: Patients participated in an outpatient phase III CR program for 6 months. The weekly supervised exercise session at the clinic consisted of approximately 20 min of warm-up exercises including stretching and calisthenics, followed by $20-30 \mathrm{~min}$ of continuous upright aerobic and dynamic exercise (various combinations of walking, bicycling, jogging, and other activities) and light isometric exercise, such as hand weights, and approximately $20 \mathrm{~min}$ of cool-down stretching and calisthenics. The intensity of exercise was prescribed individually at the anaerobic threshold level measured by a symptom-limited treadmill exercise test at baseline. In addition to the supervised exercise session, patients were encouraged to exercise twice a week outside of the clinic. Each patient's exercise prescription was also periodically adjusted on the basis of repeated treadmill exercise test to encourage a gradual increase in overall exercise performance.

Components: exercise and education.

Setting: supervised in a centre and independent at home.

\section{Aerobic exercise:}

Modality: e.g. walking, bicycling, jogging.

Length of session: 60-70 min.

Frequency: weekly at centre plus twice a week at home.

Intensity: prescribed individually.

Resistance training included? Calisthenics.

Total duration: 6 months.

Co-interventions: Patients were encouraged and interviewed at the supervised exercise session by physicians, dietitians, nurses, and exercise physiologists to comply with both the exercise and dietary education of the programme throughout its duration.

Comparator: Patients were followed by an individual physician as a usual outpatient.

Co-interventions: none described.

\begin{tabular}{|c|c|}
\hline Outcomes & Health-related quality of life at 6 months. \\
\hline Source of funding & $\begin{array}{l}\text { Health Sciences Research Grants from Ministry of Health and Welfare (Comprehensive Research on Ag- } \\
\text { ing and } \\
\text { Health). }\end{array}$ \\
\hline Conflicts of interest & NR \\
\hline \multicolumn{2}{|l|}{ Notes } \\
\hline \multicolumn{2}{|l|}{ Risk of bias } \\
\hline Bias & Authors' judgement Support for judgement \\
\hline $\begin{array}{l}\text { Random sequence genera- } \\
\text { tion (selection bias) }\end{array}$ & "randomly assigned..by envelope method" \\
\hline $\begin{array}{l}\text { Allocation concealment } \\
\text { (selection bias) }\end{array}$ & "randomly assigned..by envelope method" \\
\hline
\end{tabular}


Seki 2003 (Continued)
Blinding of outcome as-
Unclear risk
Blinding not described. sessment (detection bias)

All outcomes

\begin{tabular}{lll}
\hline $\begin{array}{l}\text { Incomplete outcome data } \\
\text { (attrition bias) } \\
\text { All outcomes }\end{array}$ & Low risk 38 patients accounted for. \\
\hline $\begin{array}{l}\text { Selective reporting (re- } \\
\text { porting bias) }\end{array}$ & Low risk & All outcomes are reported for all time points. \\
\hline $\begin{array}{l}\text { Groups balanced at base- } \\
\text { line }\end{array}$ & Low risk & $\begin{array}{l}\text { "...age and body mass index, the prevalence of hypertension, smoking and di- } \\
\text { abetes, as well as the other clinical characteristics, were not statistically differ- } \\
\text { ent between the groups." }\end{array}$
\end{tabular}

Intention-to-treat analysis High risk No.
conducted

No.

\begin{tabular}{|c|c|c|}
\hline $\begin{array}{l}\text { Groups received same } \\
\text { treatment (apart from the }\end{array}$ & High risk & $\begin{array}{l}\text { "The program included an exercise session and exercise prescription, and a di- } \\
\text { etary and educational program." }\end{array}$ \\
\hline
\end{tabular}
intervention)

Seki 2008

$\begin{array}{ll}\text { Methods } & \text { Study design: Single centre RCT } \\ \text { Country: Japan } \\ \text { Dates patients recruited: NR } \\ \text { Maximum follow up: NR }\end{array}$

Participants Inclusion criteria: $>65$ years old with stable CAD

Exclusion criteria: Ongoing congestive heart failure, liver dysfunction, renal dysfunction, or systemic diseases, including malignancy and collagen disease.

N Randomised: total: 39; intervention: 20; comparator: 19

\section{Diagnosis (\% of pts):}

stable CAD: $100 \%$

MI: $46 \%$

PCI: $31 \%$

CABG: $36 \%$

Age (mean \pm SD): intervention: $69 \pm 3$; comparator: $70 \pm 4$

Percentage male: intervention: 100\%; comparator: 100\% Ethnicity: NR

Intervention: Weekly outpatient phase III cardiac rehabilitation programme that included an exercise session, exercise prescription, dietary instruction and an educational programme for 6 months. Supervised exercise sessions at the clinic consisted of approximately 15 min of warm-up exercises including stretching, followed by 20 to 60 min of continuous upright aerobic exercise and light isotonic exercise such as sit-ups and squatting using the patient's own body weight, followed by approximately $15 \mathrm{~min}$ of cool-down stretching and calisthenics. The intensity of exercise was prescribed individually at the anaerobic threshold (AT) level as measured by a treadmill exercise test using expiratory gas analysis 
Seki 2008 (Continued)

or a rating of 12 to 13 on the standard Borg perceived exertion scale. In addition to the weekly supervised exercise sessions, subjects were encouraged to perform aerobic exercise twice weekly ( $\geq 30 \mathrm{~min}$ ) at home at an intensity of heat rate of AT or a rating of 12 to 13 on the Borg scale.

Components: exericse and education.

Setting: centre and home.

\section{Aerobic exercise:}

Modality: e.g. walking, bicycling, jogging.

Length of session: 50 to $110 \mathrm{~min}$ at the centre; $\geq 30 \mathrm{~min}$ at home.

Frequency: weekly at the centre plus twice a week at home.

Intensity: 12 to 13 on the standard Borg scale.

Resistance training included? Calisthenics.

Total duration: 6 months.

Co-interventions: Patients were instructed about the phase II diet of the American Heart Association at the beginning and every 2 months of the study. An educational programme was also given to each subject by physicians and nurses regarding ischemic heart disease and risk factors at baseline. Subjects were frequently encouraged by physicians, dietitians, nurses, and exercise physiologists to comply with both exercise and dietary instructions throughout the programme. Standard medical care was provided for both groups. Lipid-lowering drugs and other medications that may affect lipid levels were given at stable doses for at least 4 weeks before entry, and the doses of these medications were not altered during the study period.

Comparator: usual outpatient care.

Co-interventions: none described.

\begin{tabular}{ll} 
Outcomes & Total mortality; non-fatal/fatal mortality. \\
\hline Source of funding & $\begin{array}{l}\text { Health Sciences Research Grants from Ministry of Health, Labour and Welfare (Comprehensive Re- } \\
\text { search on } \\
\text { Aging and Health). }\end{array}$
\end{tabular}

Conflicts of interest NR

\begin{tabular}{ll}
\hline Notes & "No subject in either group showed any worsening of symptoms or had clinical events during this \\
study."
\end{tabular}
study."

\section{Risk of bias}

\begin{tabular}{lll}
\hline Bias & Authors' judgement & Support for judgement \\
\hline $\begin{array}{l}\text { Random sequence genera- } \\
\text { tion (selection bias) }\end{array}$ & Unclear risk & "randomly assigned" \\
\hline $\begin{array}{l}\text { Allocation concealment } \\
\text { (selection bias) }\end{array}$ & Unclear risk & Not reported. \\
\hline $\begin{array}{l}\text { Blinding of outcome as- } \\
\text { sessment (detection bias) } \\
\text { All outcomes }\end{array}$ & Unclear risk & Blinding not described. \\
\hline $\begin{array}{l}\text { Incomplete outcome data } \\
\text { (attrition bias) }\end{array}$ & Unclear risk & No information reported. \\
\hline
\end{tabular}


Seki 2008 (Continued)

All outcomes

Selective reporting (re- Low risk $\quad$ All outcomes were reported for all time points.
porting bias)

\begin{tabular}{lll}
\hline $\begin{array}{l}\text { Groups balanced at base- } \\
\text { line }\end{array}$ & Low risk & $\begin{array}{l}\text { "Age and BMI, as well as the prevalence of smoking, hypertension, and dia- } \\
\text { betes and other clinical characteristics, were not statistically different be- } \\
\text { tween groups." }\end{array}$ \\
\hline $\begin{array}{l}\text { Intention-to-treat analysis } \\
\text { conducted }\end{array}$ & Unclear risk & Unclear. \\
\hline $\begin{array}{l}\text { Groups received same } \\
\text { treatment (apart from the } \\
\text { intervention) }\end{array}$ & High risk & $\begin{array}{l}\text { "The intervention group participated in a phase III cardiac rehabilitation pro- } \\
\text { gramme consisting of exercise training, diet therapy, and weekly counselling } \\
\text { for } 6 \text { months. In the control group, usual outpatient care was provided". }\end{array}$ \\
\hline
\end{tabular}

Shaw 1981

Study design: Multicentre RCT (5 sites)
Country: USA
Dates patients recruited: 1976
Maximum follow up: 5 years
Participants were randomised after completion of a 6-week, low-level-exercise-programme run-in pe-
riod.

Inclusion criteria: Documented $\mathrm{MI} \geq 8$ weeks but $\leq 3$ years before being enrolled. Other eligibility criteria included the ability to exercise at an intensity level $\geq 3$ metabolic equivalents (METs) and a supine resting diastolic blood pressure $<100 \mathrm{mmHg}$.

Exclusion criteria: Patients were considered ineligible if they had any other significant coexisting CVD or other disease likely to be fatal in the near future, uncontrolled diabetes mellitus, complete heart block with or without ventricular pacemaker, or emotional or physical impairments that would make participation and adherence difficult, or if they were already participants in a formal exercise programme.

N Randomised: total:651; intervention: 323; comparator: 328

Diagnosis (\% of pts): MI: $100 \%$

Age (mean \pm SD): intervention: $51.5 \pm 7.4$; comparator: $52.1 \pm 7.2$

Percentage male: intervention: $100 \%$; comparator: $100 \%$

Ethnicity \% white: intervention: $93.3 \%$; comparator: $94.4 \%$

Intervention: An exercise prescription was developed on the basis of each patient's multistage graded exercise test (MSET) results. An exercise target heart rate guided the prescription and was determined as $85 \%$ of the peak heart rate achieved on the test. This group performed brisk physical activity in the laboratory for 8 weeks, exercising 1 hour per day, 3 days per week. The patients were supervised and underwent continuous ECG monitoring. Each individual exercised for 4 minutes on each of 6 stationary machines with a 2-minute rest interval between machines. Attainment of the target heart rate was the goal for every 4-minute exercise period.

After 8 weeks, participants exercised in a gymnasium or swimming pool without ECG monitoring, although exercise heart rates were periodically checked. Activities consisted of 15 minutes of continuous jogging, cycling, or swimming, followed by 25 minutes of recreational games. The activities were performed at an intensity level enabling each participant to reach his individually prescribed target heart 
rate. The men were encouraged to attend 3 sessions per week but in some situations were allowed to exercise on their own.

Components: exercise only.

Setting: group sessions in centre ("but in some situations were allowed to exercise on their own").

\section{Aerobic exercise:}

Modality: "brisk physical activity" on "stationary machines".

Length of session: $40 \mathrm{~min}$.

Frequency: 3 days per week.

Intensity: $85 \%$ of the peak heart rate.

\section{Resistance training included?}

Total duration: 8 weeks in the laboratory, followed by regular jogging, cycling, or swimming and recreational games.

Co-interventions: none described.

Comparator: Participants in the non-exercising control group were encouraged to maintain normal routines but not to participate in any regular exercise programme.

Co-interventions: none described.

\begin{tabular}{|c|c|}
\hline Outcomes & Total \& CHD mortality, non fatal MI. \\
\hline Source of funding & National Heart, Lung, and Blood Institute. \\
\hline Conflicts of interest & NR \\
\hline Notes & $\begin{array}{l}90 \% \text { of ET attended } 90 \% \text { of } 24 \text { scheduled sessions post-randomisation, only } 48 \% \text { attending }>50 \% \text { of } \\
\text { sessions at } 18 \text { months. } \\
30 \% \text { of control alleged exercising regularly, on own initiative. } \\
\text { At } 19 \text { years any protective effect from the programme had decreased over time, but an increase with } \\
\text { PWC from the beginning to the end of the trial was associated with a consistent reduction in mortality } \\
\text { throughout the } 19 \text { years of follow up. }\end{array}$ \\
\hline
\end{tabular}

\section{Risk of bias}

\begin{tabular}{lll}
\hline Bias & Authors' judgement & Support for judgement \\
\hline $\begin{array}{l}\text { Random sequence genera- } \\
\text { tion (selection bias) }\end{array}$ & Unclear risk & Sequence generation not described...."the men were randomly assigned." \\
\hline $\begin{array}{l}\text { Allocation concealment } \\
\text { (selection bias) }\end{array}$ & Unclear risk & Allocation concealment not described. \\
\hline $\begin{array}{l}\text { Blinding of outcome as- } \\
\text { sessment (detection bias) } \\
\text { All outcomes }\end{array}$ & Unclear risk & Blinding not described. \\
\hline $\begin{array}{l}\text { Incomplete outcome data } \\
\text { (attrition bias) } \\
\text { All outcomes }\end{array}$ & High risk & $6.5 \%$ lost to follow up, no description of withdrawals or dropouts. \\
\hline
\end{tabular}


Shaw 1981 (Continued)
Selective reporting (re-
Low risk
All outcomes reported for all time points. porting bias)

Groups balanced at base- Low risk
line
line
"With the exception of resting heart rate, which was on average lower in control subjects than in the exercise group, no significant differences were noted between the groups for any of the baseline characteristics."

\begin{tabular}{|c|c|c|}
\hline $\begin{array}{l}\text { Intention-to-treat analysis } \\
\text { conducted }\end{array}$ & Low risk & "Intention-to-treat methodology was used in all primary analyses" \\
\hline $\begin{array}{l}\text { Groups received same } \\
\text { treatment (apart from the } \\
\text { intervention) }\end{array}$ & Low risk & $\begin{array}{l}\text { "The men In the exercise group pursued intensive exercise In the laboratory } \\
\text { for } 6 \text { weeks and then in a gymnasium for } 34 \text { months." }\end{array}$ \\
\hline
\end{tabular}

\section{Sivarajan 1982}

$\begin{array}{ll}\text { Methods } & \text { Study design: Multicentre RCT (7 sites) } \\ \text { Country: USA } & \text { Dates patients recruited: } 1 \text { September } 1977 \text { to } 2 \text { December } 1979 \\ & \text { Maximum follow up: } 6 \text { months } \\ & \text { Random allocation of individuals to two intervention groups (exercise only [Intervention B1] or exercise } \\ & \text { plus teaching and counselling [Intervention B2]) and a control group (usual care). }\end{array}$

Participants

Inclusion criteria: Previous MI, age $<70$ years, living $<50$ miles of centre.

Exclusion criteria: prolonged complications, physical limitations, noncardiac or cardiac diseases, communication porblems, other issues e.g. massive obesity, psychological problems, etc.

N Randomised: total: 258; Intervention B1: 88; Intervention B2: 86; comparator: 84

Diagnosis (\% of pts): AMI: $100 \%$

Age (mean \pm SD): Intervention B1: $55.6 \pm 9.3$; Intervention B2: $56.3 \pm 8.3$; comparator $=57.1+/-7.3$

Percentage male: $>80 \%$

Ethnicity: $>80 \%$ caucasion

Intervention: The outpatient exercise programme was identical for the patients in groups Bl and B2. It consisted of a gradually progressive calisthenic and walking programme prescribed at weekly 30 minute clinic visits and performed by the patient at home. Patients were instructed to exercise twice a day until they returned to work and once a day thereafter. If the patient was symptom free, the prescription was gradually increased to add calisthenics of increasing intensity and the distance and time (or rate) of walking were gradually advanced.

Components: exercise only or exercise plus education and counselling.

Setting: centre and home.

\section{Aerobic exercise:}

Modality: walking.

Length of session: NR

Frequency: twice a day until return to work and once a day thereafter. 
Sivarajan 1982 (Continued)

\section{Intensity: NR}

Resistance training included? calisthenics.

\section{Total duration: NR}

Co-interventions: Patients in group B2, in addition to receiving exercise prescriptions as described above, attended a series of eight 1-hour group sessions during weekly clinic visits. The sessions emphasised the practical aspects of anatomy and physiology of the heart, coronary artery disease, myocardial infarction and medications; risk factors, including smoking, hypercholesterolemia, hypertension, stress and sedentary living; nutritional aspects of fats, cholesterol, salt and alcohol; activities and exercises; emotional reactions to myocardial infarction

in patients and their families; resumption of sexual activity; and issues concerning return to work or, if retired, to an alternative, meaningful lifestyle.

Comparator: conventional medical and nursing management throughout all phases of hospitalisation and convalescence at home.

Co-interventions: none described.

\begin{tabular}{ll}
\hline Outcomes & Total mortality; health-related quality of life: Sickness Impact Profile. \\
\hline Source of funding & Bureau of Health Professions, Division of Nursing, Department of Health and Human Services. \\
\hline Conflicts of interest & NR \\
\hline Notes & $\begin{array}{l}\text { Several reports of the same trial all with various bits of information. Study authors conclude that multi- } \\
\text { ple intervention trial of this short duration did not change patient's behaviour. MI itself acts as a strong } \\
\text { stimulus to alter behaviour with respect to risk factors. }\end{array}$
\end{tabular}

\section{Risk of bias}

\begin{tabular}{lll}
\hline Bias & Authors' judgement & Support for judgement \\
\hline $\begin{array}{l}\text { Random sequence genera- } \\
\text { tion (selection bias) }\end{array}$ & Unclear risk & Not reported. \\
\hline $\begin{array}{l}\text { Allocation concealment } \\
\text { (selection bias) }\end{array}$ & Unclear risk & Not reported. \\
\hline $\begin{array}{l}\text { Blinding of outcome as- } \\
\text { sessment (detection bias) } \\
\text { All outcomes }\end{array}$ & Unclear risk & Blinding not described. \\
\hline $\begin{array}{l}\text { Incomplete outcome data } \\
\text { (attrition bias) } \\
\text { All outcomes }\end{array}$ & High risk & 24\% lost to follow up, no description of withdrawals or dropouts. \\
\hline $\begin{array}{l}\text { Selective reporting (re- } \\
\text { porting bias) }\end{array}$ & Low risk & All outcomes reported at all time points. \\
\hline $\begin{array}{l}\text { Groups balanced at base- } \\
\text { line }\end{array}$ & Low risk & No statistically significant differences between the groups was reported. \\
\hline $\begin{array}{l}\text { Intention-to-treat analysis } \\
\text { conducted }\end{array}$ & High risk & No. \\
\hline
\end{tabular}


Sivarajan 1982 (Continued)

Groups received same treatment (apart from the intervention)
High risk

"A, a control group; B1, a group of patients who were provided with an exercise program in the hospital and a continued exercise program during weekly clinic appointments for the first 3 months after discharge; and B2, a group of patients who were provided with the same exercise program as the Bl group and were also given a teaching-counseling program about risk factors and emotional adjustment after discharge from the hospital.

\section{Specchia 1996}

Methods Study design: Single centre RCT

Country: Italy

Dates patients recruited: NR (40-month period)

Maximum follow up: mean 34.5 months

\section{Participants}

Inclusion criteria: Patients $<65$ years of age who had not had previous MI, admitted due to chest pain lasting $>30$ minutes and because they had a diagnosis of AMI based on evolutionary ECG changes and serum kinase elevation.

Exclusion criteria: Complicated in-hospital clinical course e.g. postinfarction angina requiring urgent revascularisation; evidence of congestive HF; chronic concomitant illnesses or musculoskeletal handicaps that would prevent them from finishing the exercise training period.

N Randomised: total: 256; intervention: 125; comparator: 131

\section{Diagnosis ( $\%$ of pts):}

MI: $100 \%$

Prior angina: $42 \%$

Age (Mean \pm SD): intervention: $51.5 \pm 7$; comparator: $54.3 \pm 8$

Percentage male: $91 \%$ intervention: $91 \%$; comparator: $91 \%$

Ethnicity: NR

Intervention: Patients underwent a 4-week physical training period consisting of supervised training sessions of 30 minutes of bicycle ergometry five times a week combined with calisthenics. Training intensity was graded according to $75 \%$ of maximal work capacity reached in the previous exercise test. At the end of the 4-week training period, a second symptom-limited exercise test was performed. Patients were then discharged with the instructions to continue the calisthenics daily and to walk for $\geq 30 \mathrm{~min}$ utes every 2 days

Components: exericse, education and psychology.

Setting: centre and then home.

\section{Aerobic exercise:}

Modality: bicycle ergometry in centre followed by calisthenics and walking at home.

Length of session: $\geq 30$ minutes.

Frequency: five times a week in centre followed by daily calisthenics and walking every other day.

Intensity: $75 \%$ of maximal work capacity.

Resistance training included? Calisthenics. 
Total duration: 4 weeks supervised and then continued at home.

Co-interventions: All patients went to the Rehabilitation Center for 3 weeks.and underwent a symptom-limited exercise test ( $28 \pm 2$ days after myocardial infarction), 24-hour Holter monitoring, and coronary arteriography ( $31 \pm 3$ days after the acute episode). All patients attended colloquial sessions, held by a cardiologist and a psychologist, dealing with secondary prevention of cardiovascular diseases and stressing dietary changes and smoking cessation.

Comparator: Discharged after rehab centre and clinically re-examined 1 month later when they underwent a second symptom-limited exercise test.

Co-interventions: as above.

\begin{tabular}{ll}
\hline Outcomes & CHD mortality, revascularisations. \\
\hline Source of funding & NR. \\
\hline Conflicts of interest & NR. \\
\hline Notes & $\begin{array}{l}\text { Ejection fraction (EF) was the only prognostic factor. } \\
\text { Among } 51 \text { patients with } E F<41 \%, \text { relative risk for the } 27 \text { untrained participants was } 8.63 \text { times higher } \\
\text { than for } 24 \text { trained ones. }(P=0.04) \\
\text { If } E F>40 \% \text {, estimated risk for untrained participant was } 1.07 \text { times higher than for trained. }\end{array}$ \\
\hline
\end{tabular}

\section{Risk of bias}

\begin{tabular}{|c|c|c|}
\hline Bias & Authors' judgement & Support for judgement \\
\hline $\begin{array}{l}\text { Random sequence genera- } \\
\text { tion (selection bias) }\end{array}$ & Unclear risk & "randomized" \\
\hline $\begin{array}{l}\text { Allocation concealment } \\
\text { (selection bias) }\end{array}$ & Unclear risk & Not reported. \\
\hline $\begin{array}{l}\text { Blinding of outcome as- } \\
\text { sessment (detection bias) } \\
\text { All outcomes }\end{array}$ & Unclear risk & Blinding not described. \\
\hline $\begin{array}{l}\text { Incomplete outcome data } \\
\text { (attrition bias) } \\
\text { All outcomes }\end{array}$ & Low risk & No losses to follow up. \\
\hline $\begin{array}{l}\text { Selective reporting (re- } \\
\text { porting bias) }\end{array}$ & High risk & $\begin{array}{l}\text { While survival data is provided, detailed clinical information was obtained } \\
\text { from all patients at 3- to 4-month intervals and this data is not reported. }\end{array}$ \\
\hline $\begin{array}{l}\text { Groups balanced at base- } \\
\text { line }\end{array}$ & High risk & $\begin{array}{l}\text { "There was a small but significant difference in age between the two groups } \\
\text { ( } 51.5 \pm 5 \text { in group } 1 \text { versus } 54.3 \pm 6 \text { in group } 2, P<.01) \text { ". }\end{array}$ \\
\hline $\begin{array}{l}\text { Intention-to-treat analysis } \\
\text { conducted }\end{array}$ & Low risk & Yes. \\
\hline $\begin{array}{l}\text { Groups received same } \\
\text { treatment (apart from the } \\
\text { intervention) }\end{array}$ & Low risk & $\begin{array}{l}\text { "Patients were randomized either to a 4-week training period or a control } \\
\text { group..... all patients attended colloquial sessions, held by a cardiologist and } \\
\text { a psychologist, dealing with secondary prevention of cardiovascular diseases } \\
\text { and stressing dietary changes and smoking cessation". }\end{array}$ \\
\hline
\end{tabular}


Study design: Single centre RCT

Country: USA

Dates patients recruited: NR

Maximum follow up: 1 year.

Randomised by blocks of 6 into one of three groups: exercise, group counselling \& control.

Participants

Inclusion criteria: Aged 30 to 69 years with documented MI not less than six weeks nor more than one year prior to admission to the study. Work capacity level $<7$ MET (men) or $<6$ MET (women) or a Taylor Manifest Anxiety Scale raw score of $19+$ or Zung Self-rating Depression Scale raw score of $40+$, or any or all of these.

Exclusion criteria: Presence of unstable cardiovascular condition i.e. congestive heart failure, or requirement of treatment for any physical/psychological reason.

N Randomised: total: 106; intervention: 42; comparator (usual care): 29; group counselling: 35 (no data analysed in this review)

Diagnosis (\% of pts): MI: $100 \%$

Age (mean): 54

Percentage male: intervention: $90 \%$; comparator: $76 \%$

Ethnicity: $85 \%$ white

Interventions

Intervention: Three one-hour sessions per week over a 12-week period. All exercises were dynamic, involving rhythmic movements against resistance. Half were upper limb (rowing machine, arm wheel, and arm ergometer) and half were lower limb (treadmill, cycle, and step ergometer). Patients exercised upper and lower limbs alternately for four minutes with two minutes of rest in between. The intensity of exercise was determined by heart-rate response, the target level being $85 \%$ of the peak exercise heart rate achieved in the first evaluation. If the heart rate was consistently above or below target, the work load was increased or decreased.

Components: exercise.

Setting: supervised in a centre.

\section{Aerobic exercise:}

Modality: e.g. rowing, treadmill, cycle or step ergometer.

Length of session: 1 hour.

Frequency: 3 times a week.

Intensity: Target HR 85\% of HR max during exercise treadmill test.

Resistance training included? No.

Total duration: 12 weeks.

Co-interventions: none described.

Comparator: followed up by their physicians and given routine post-MI medical care. Patients were requested to not join a supervised exercise or a formal counselling programme.

Co-interventions: none described. 
Stern 1983 (Continued)

Source of funding National Institute of Handicapped Research, Department of Education, Washington, DC.

\begin{tabular}{ll}
\hline Conflicts of interest & NR \\
\hline Notes & Minimal differences between groups at one year.
\end{tabular}

\section{Risk of bias}

\begin{tabular}{|c|c|c|}
\hline Bias & Authors' judgement & Support for judgement \\
\hline $\begin{array}{l}\text { Random sequence genera- } \\
\text { tion (selection bias) }\end{array}$ & Unclear risk & Not reported. \\
\hline $\begin{array}{l}\text { Allocation concealment } \\
\text { (selection bias) }\end{array}$ & Unclear risk & Not reported. \\
\hline $\begin{array}{l}\text { Blinding of outcome as- } \\
\text { sessment (detection bias) } \\
\text { All outcomes }\end{array}$ & Unclear risk & Blinding not described. \\
\hline $\begin{array}{l}\text { Incomplete outcome data } \\
\text { (attrition bias) } \\
\text { All outcomes }\end{array}$ & High risk & $7.7 \%$ lost to follow up, no description of withdrawals or dropouts. \\
\hline $\begin{array}{l}\text { Selective reporting (re- } \\
\text { porting bias) }\end{array}$ & Low risk & All outcomes reported for all time points. \\
\hline $\begin{array}{l}\text { Groups balanced at base- } \\
\text { line }\end{array}$ & High risk & $\begin{array}{l}\text { "More controls were in the unmarried category }(P<0.003) \text {, more exercise pa- } \\
\text { tients were in the } 49 \text { - to } 58 \text {-year-old age range }(P<.02) \text {, and more group pa- } \\
\text { tients were admitted less than four months following myocardial infarction ( } P \\
<0.05) \text { ". }\end{array}$ \\
\hline $\begin{array}{l}\text { Intention-to-treat analysis } \\
\text { conducted }\end{array}$ & High risk & No. \\
\hline \multirow{2}{*}{$\begin{array}{l}\text { Groups received same } \\
\text { treatment (apart from the } \\
\text { intervention) }\end{array}$} & Low risk & $\begin{array}{l}\text { "Randomization to one of three groups, exercise, group counseling, or con- } \\
\text { trol." }\end{array}$ \\
\hline & & $\begin{array}{l}\text { "Patients in the control group received no specific assignment. Instead, they } \\
\text { were followed up by their physicians and given routine postmyocardial infarc- } \\
\text { tion medical care. They were requested to not join a supervised exercise or a } \\
\text { formal counselling program." }\end{array}$ \\
\hline
\end{tabular}

\section{Ståhle 1999}

\begin{tabular}{ll} 
Methods & Study design: Single centre RCT \\
Country: Sweden & Dates patients recruited: October 1994 to June 1997 \\
& Maximum follow up: 1 year \\
\hline Participants & $\begin{array}{l}\text { Inclusion criteria: Patients } \geq 65 \text { years admitted because of an acute coronary event. To be included the } \\
\text { patients had to perform a predischarge exercise test at a workload } \geq 70 \text { W in men and } \geq 50 \text { W in women. } \\
\text { For the group with unstable angina pectoris a ST60 depression of }>1 \text { mm in } \geq \text { two adjacent leads had to } \\
\text { be documented at the exercise test. }\end{array}$
\end{tabular}


Exclusion criteria: Neurological sequelae, memory dysfunction, orthopaedic disability, inability to understand Swedish, coronary intervention planned within 3 months or other complicating diseases.

N Randomised: total: 109; intervention: 56; comparator: 53

\section{Diagnosis (\% of pts):}

Congestive heart failure: $6 \%$

Previous AMI: $27 \%$

Angina pectoris: $38 \%$

Previous PCI: $11 \%$

Previous CABG: $17 \%$

Age years, (range): intervention: 71 (64-84); comparator: 68 (65-83)

Percentage male: intervention: 73\%; comparator: 75\%

Ethnicity: NR

Intervention: 50 min aerobic outpatient group-training programme (including warm-up and cooldown) 3 times a week for 3 months. Complete programme was supervised by specialised physiotherapist and supported by music which guided intensity of performance during session. Training followed by 10 min of music-supported relaxation. After 3 months, patients had possibility of participating in programme once a week for another 3 months.

Components: exercise.

Setting: supervised centre-based group sessions.

\section{Aerobic exercise:}

Modality: NR

Length of session: 50 min plus 10 min relaxation.

Frequency: 3 times a week.

Intensity: NR

\section{Resistance training included? NR}

Total duration: 3 months followed by opportunity to continue once a week for another 3 months.

\section{Co-interventions:}

Comparator: Usual care - encouraged to re-start usual/prior physical activity as soon as they felt fit.

Co-interventions: NR

Outcomes Total mortality, CABG, PCI, health-related quality of life; Karolinska Questionnaire at 12-months.

Source of funding National Association for Heart and Lung Patients, the Swedish Heart and Lung Foundation, the Swedish Foundation of Health Care Sciences and Allergy Research, and the King Gustaf V and Queen Victoria Foundation.

Conflicts of interest

NR

\section{Notes}

\section{Risk of bias}

Bias Authors' judgement Support for judgement


Ståhle 1999 (Continued)

Random sequence genera- $\quad$ Unclear risk Not reported.
tion (selection bias)

\begin{tabular}{ll}
\hline $\begin{array}{l}\text { Allocation concealment } \\
\text { (selection bias) }\end{array}$ & Unclear risk reported.
\end{tabular}

\begin{tabular}{|c|c|c|}
\hline $\begin{array}{l}\text { Blinding of outcome as- } \\
\text { sessment (detection bias) } \\
\text { All outcomes }\end{array}$ & Unclear risk & Blinding not described. \\
\hline $\begin{array}{l}\text { Incomplete outcome data } \\
\text { (attrition bias) } \\
\text { All outcomes }\end{array}$ & High risk & $\begin{array}{l}\text { Clinical event data for } 8(7 \%) \text { who withdrew before } 3 \text { months were not ac- } \\
\text { counted for at } 1 \mathrm{yr} \text {. }\end{array}$ \\
\hline $\begin{array}{l}\text { Selective reporting (re- } \\
\text { porting bias) }\end{array}$ & Low risk & All outcomes were reported at all time points. \\
\hline $\begin{array}{l}\text { Groups balanced at base- } \\
\text { line }\end{array}$ & Low risk & $\begin{array}{l}\text { "At baseline the two groups were well balanced as regards clinical characteris- } \\
\text { tics and pharmacological treatment.". }\end{array}$ \\
\hline $\begin{array}{l}\text { Intention-to-treat analysis } \\
\text { conducted }\end{array}$ & High risk & No. \\
\hline $\begin{array}{l}\text { Groups received same } \\
\text { treatment (apart from the } \\
\text { intervention) }\end{array}$ & Low risk & $\begin{array}{l}\text { "Prior to discharge, all patients received verbal and written information about } \\
\text { the importance of regular physical activity....Patients were randomized to ei- } \\
\text { ther a supervised out-patient group-training programme }(n=50) \text { or to a control } \\
\text { group }(n=51) . "\end{array}$ \\
\hline
\end{tabular}

\section{Toobert 2000}

\begin{tabular}{ll}
\hline Study design: Single centre RCT \\
Country: USA \\
Dates patients recruited: NR \\
Maximum follow up: 24 months \\
Inclusion criteria: Postmenopausal women with coronary heart disease, defined as atherosclerosis, \\
MI, percutaneous transluminal coronary angioplasty, and/or coronary bypass graft surgery. \\
Exclusion criteria: Other life-threatening illnesses, infarction during the preceding 6 weeks, receiving \\
streptokinase or alteplase, or being scheduled for bypass surgery. \\
N Randomised: total: 25 ; intervention: 14 ; comparator: 11 \\
Diagnosis (\% of pts): \\
CHD: $100 \%$ \\
Previous AMI: $52 \%$ \\
PCI: $36 \%$ \\
CABG: $28 \%$ \\
Age (mean \pm SD): intervention: $64 \pm 10 ;$ comparator: $63 \pm 11$ \\
Percentage male: intervention: $0 \%$; comparator: $0 \%$ \\
Ethnicity: $92 \%$ white
\end{tabular}


Toobert 2000 (Continued) Interventions

Intervention: Daily group physical activity sessions included warm-up, walking or aerobics, and a cooldown. Participants were individually prescribed exercise intensity based on their treadmill exercise test performance. Following the retreat, the intervention exercise programme required participants to engage in a 1-hour session per day at least 3 days each week.

Components: exercise, education and psychological support.

Setting: supervised sessions in a centre followed by home.

\section{Aerobic exercise:}

Modality: walking or aerobics.

Length of session: 1 hour.

Frequency: daily and then at least 3 days a week.

Intensity: individually prescribed.

Resistance training included? no.

Total duration: 24 months.

Co-interventions: Participants randomised to the PrimeTime programme began the intervention with a 7-day retreat. Women were encouraged to bring their partner. As well as physical activity, the daily schedule included cooking classes, instruction in stress-management techniques including Hatha Yoga stretches, progressive deep relaxation, deep breathing, meditation, group support, smoking cessation and directed or receptive imagery. Twice-weekly 4-hour meetings followed the retreat with each meeting following a sequence similar to the retreat schedule:

Comparator: usual care.

Co-interventions: none described.

Outcomes Health-related quality of life: SF-36 at 24 months

Source of funding National Heart, Lung, and Blood Institute

Conflicts of interest NR

Notes

\section{Risk of bias}

\begin{tabular}{lll}
\hline Bias & Authors' judgement & Support for judgement \\
\hline $\begin{array}{l}\text { Random sequence genera- } \\
\text { tion (selection bias) }\end{array}$ & Unclear risk & "randomized" \\
\hline $\begin{array}{l}\text { Allocation concealment } \\
\text { (selection bias) }\end{array}$ & Unclear risk & Not reported \\
\hline
\end{tabular}

Blinding of outcome as- Unclear risk Blinding not described

sessment (detection bias)

All outcomes

\begin{tabular}{|c|c|c|}
\hline $\begin{array}{l}\text { Incomplete outcome data } \\
\text { (attrition bias) }\end{array}$ & High risk & $\begin{array}{l}3 / 28(10.7 \%) \text { patients lost to follow-up, no description of withdrawals or } \\
\text { dropouts. }\end{array}$ \\
\hline
\end{tabular}


Toobert 2000 (Continued)

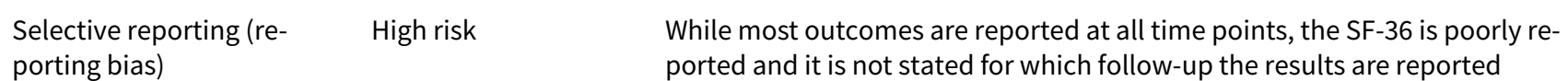
porting bias) ported and it is not stated for which follow-up the results are reported

Groups balanced at base- High risk line
"No significant group differences were found on self-efficacy, any demographic and medical history variables except number of co-morbidities"

Intention-to-treat analysis Unclear risk Unclear
conducted

conducted

Groups received same High risk
treatment (apart from the intervention)

Intervention = "comprehensive lifestyle management program (very low-fat vegetarian diet, smoking cessation, stress-management training, moderate exercise, and group support)"

"The UC group received no intervention beyond the usual care of their physician."

Vecchio 1981

$\begin{array}{ll}\text { Methods } & \text { Study design: RCT } \\ \text { Country: Italy } \\ \text { Dates patients recruited: NR } \\ \text { Maximum follow up: } 1 \text { year } \\ \text { Randomised after exercise treadmill test, } 30 \text { days after MI. } \\ \text { Inclusion criteria: patients aged } 40 \text { to } 60 \text { yrs with MI } \\ \text { Exclusion criteria: more than one previous MI } \\ \text { N Randomised: total: } 50 ; \text { intervention: } 25 ; \text { comparator: } 25 \\ \text { Diagnosis (\% of pts): MI: } 100 \% \\ \text { Age (mean } \pm \text { SD): intervention: } 50.1 \pm 5.5 \text {; comparator: } 50.1 \pm 6.3 \\ \text { Percentage male: intervention: } 100 \% \text {; comparator: } 100 \% \\ \text { Ethnicity: } 100 \% \text { Italians }\end{array}$

Interventions

Intervention: 6 weeks physical activity programme

Components: exercise

Setting: NR

Aerobic exercise: NR

Modality: NR

Length of session: NR

Frequency: NR

Intensity: NR

Resistance training included? NR

Total duration: 6 weeks 
Vecchio 1981 (Continued)

\section{Co-interventions: NR}

Comparator: after discharge a simple plan of daily exercises (intensity $\leq 3 \mathrm{METs}$ ) to perform at home

Co-interventions: NR

\begin{tabular}{ll}
\hline Outcomes & CV mortality \\
\hline Source of funding & NR \\
\hline Conflicts of interest & NR \\
\hline Notes & $\begin{array}{l}\text { Trained patients showed a better mid-term prognosis than controls, but this could not be explained by } \\
\text { the physical training procedure. }\end{array}$ \\
\hline
\end{tabular}

\section{Risk of bias}

\begin{tabular}{|c|c|c|}
\hline Bias & Authors' judgement & Support for judgement \\
\hline $\begin{array}{l}\text { Random sequence genera- } \\
\text { tion (selection bias) }\end{array}$ & Unclear risk & Not reported. \\
\hline $\begin{array}{l}\text { Allocation concealment } \\
\text { (selection bias) }\end{array}$ & Unclear risk & Not reported. \\
\hline $\begin{array}{l}\text { Blinding of outcome as- } \\
\text { sessment (detection bias) } \\
\text { All outcomes }\end{array}$ & Unclear risk & Blinding not described. \\
\hline $\begin{array}{l}\text { Incomplete outcome data } \\
\text { (attrition bias) } \\
\text { All outcomes }\end{array}$ & High risk & $24 \%$ lost to follow up, no description of withdrawals or dropouts. \\
\hline $\begin{array}{l}\text { Selective reporting (re- } \\
\text { porting bias) }\end{array}$ & Low risk & All outcomes reported at all time points. \\
\hline $\begin{array}{l}\text { Groups balanced at base- } \\
\text { line }\end{array}$ & Low risk & $\begin{array}{l}\text { The groups are comparable in terms of age, heart's dimensions, Creatine phos- } \\
\text { phokinase (CPK) test and complications experienced during the acute phase, } \\
\text { with the exception of left ventricular insufficiency and premature beats. }\end{array}$ \\
\hline $\begin{array}{l}\text { Intention-to-treat analysis } \\
\text { conducted }\end{array}$ & Low risk & Yes. \\
\hline $\begin{array}{l}\text { Groups received same } \\
\text { treatment (apart from the } \\
\text { intervention) }\end{array}$ & Low risk & $\begin{array}{l}\text { "Following randomisation the group A patients were engaged into a } 6 \text { week } \\
\text { physical training program" }\end{array}$ \\
\hline
\end{tabular}

\section{Vermeulen 1983}

Methods Study design: Single centre RCT

Country: Netherlands

Dates patients recruited: NR

Maximum follow up: 5 years 
Vermeulen 1983 (Continued)

Randomised 4 to 6 weeks post-MI after ETT.

Participants Inclusion criteria: Men (aged 40 to 55 years) who were hospitalised within 6 hours after onset of complaints of first myocardial infarction.

Exclusion criteria: Combination of bundle branch block and anterior myocardial infarction

N Randomised: total: 98; intervention: 47; comparator: 51

Diagnosis (\% of pts): MI: $100 \%$

Age (mean \pm SD): intervention: $49.4 \pm 3.7$; comparator: $49.1 \pm 4.5$

Percentage male: intervention: $100 \%$; comparator: $100 \%$

Ethnicity: NR

Interventions

Intervention: The rehabilitation consisted of multidisciplinary intervention (physical, social, psychological).

Components: exercise, psychochological support.

Setting: Centre

Aerobic exercise:

Modality: NR

Length of session: NR

Frequency: NR

Intensity: NR

Resistance training included? NR

Total duration: 6 - 8 weeks.

Co-interventions: none described.

Comparator: usual care.

Co-interventions: none described.

\begin{tabular}{|c|c|c|}
\hline Outcomes & \multicolumn{2}{|l|}{ Mortality, non fatal MI. } \\
\hline Source of funding & \multicolumn{2}{|c|}{ Prevention Fund, The Hague. } \\
\hline Conflicts of interest & \multicolumn{2}{|l|}{ NR } \\
\hline Notes & \multicolumn{2}{|c|}{$\begin{array}{l}\text { Study authors conclude that cardiac rehab benefits patients after MI due to direct effect on myocardial } \\
\text { perfusion and to lowering of cholesterol levels. }\end{array}$} \\
\hline \multicolumn{3}{|l|}{ Risk of bias } \\
\hline Bias & Authors' judgement & Support for judgement \\
\hline $\begin{array}{l}\text { Random sequence genera- } \\
\text { tion (selection bias) }\end{array}$ & Unclear risk & "randomized" \\
\hline $\begin{array}{l}\text { Allocation concealment } \\
\text { (selection bias) }\end{array}$ & Unclear risk & Not reported. \\
\hline
\end{tabular}


Vermeulen 1983 (Continued)

Blinding of outcome as- Unclear risk Blinding not described. sessment (detection bias)

All outcomes

\begin{tabular}{lll}
\hline $\begin{array}{l}\text { Incomplete outcome data } \\
\text { (attrition bias) } \\
\text { All outcomes }\end{array}$ & Low risk & No losses to follow up. \\
\hline $\begin{array}{l}\text { Selective reporting (re- } \\
\text { porting bias) }\end{array}$ & Low risk & $\begin{array}{l}\text { All outcomes reported at all time points (although absolute values not always } \\
\text { given). }\end{array}$ \\
\hline $\begin{array}{l}\text { Groups balanced at base- } \\
\text { line }\end{array}$ & Unclear risk & Data given on age, Peak SGOT (U/L) and location of MI, only. \\
\hline $\begin{array}{l}\text { Intention-to-treat analysis } \\
\text { conducted }\end{array}$ & Low risk & Yes. \\
\hline $\begin{array}{l}\text { Groups received same } \\
\text { treatment (apart from the } \\
\text { intervention) }\end{array}$ & High risk & $\begin{array}{l}\text { "The rehabilitation took place at the Rehabilitation Institute Muiderpoort } \\
\text { and consisted of multidisciplined intervention (physical, social, psychologi- } \\
\text { cal). Other than the rehabilitation program, the medical treatment of the two } \\
\text { groups was similar." }\end{array}$ \\
\hline
\end{tabular}

$\begin{array}{ll}\text { Methods } & \text { Study design: Multicentre RCT (3 sites) } \\ \text { Country: Norway } \\ \text { Dates patients recruited: NR } \\ \text { Maximum follow up: } 2 \text { years }\end{array}$

Participants Inclusion criteria: Patients admitted to hospital for acute MI, unstable angina pectoris or after coronary artery bypass grafting.

Exclusion criteria: none described.

N Randomised: total: 197; intervention: 98; comparator: 99

Diagnosis (\% of pts):

AMI: $37 \%$

UAP stabilised: $2 \%$

PCl: $20 \%$

CABG: $25 \%$

Age (mean \pm SD): intervention: $54 \pm 8$; comparator: $55 \pm 8$

Percentage male: intervention: 91\%; comparator: $84 \%$ Ethnicity: NR

Interventions

Intervention: The first phase lasted for 6 weeks with supervised physical exercise in addition to a regular group meeting twice a week. Each training session started with 15 min of warm up followed by 20 min of dynamic endurance training, $10 \mathrm{~min}$ of active cool-down activities and finally $10 \mathrm{~min}$ of stretching and relaxation. Large muscle groups in the arms and legs were used simultaneously to achieve higher exercise intensity (11-13 on the Borg scale). No weight lifting took place. This was followed by 9 
VHSG 2003 (Continued)

weeks of supervised physical exercise twice weekly. The intensity level was increased to achieve an exertion rate equal to jogging (13-15 on the Borg scale). Patients were then encouraged to perform regular training at home.

Components: exercise, education and psychogocial support.

Setting: supervised, group sessions in a centre.

\section{Aerobic exercise:}

Modality: "dynamic endurance training".

Length of session: $55 \mathrm{~min}$.

Frequency: twice a week.

Intensity: $11-13$ on the Borg Scale, increased to $13-15$ after 6 weeks.

\section{Resistance training included? No.}

Total duration: 15 weeks.

Co-interventions: The multidisciplinary CR of "Heart School" comprised dietary advice, smoking cessation, physical activity counselling, risk factor management, psychosocial management and health education.

Comparator: Usual care: patients received usual standardised nurse-based information on CHD in general and lifestyle measures.

Co-interventions: none described.

\begin{tabular}{ll}
\hline Outcomes & Total mortality. \\
\hline Source of funding & The Norwegian Government Directory for Health and Bristol Myers Squib, Norway. \\
\hline Conflicts of interest & NR \\
\hline Notes & \\
\hline
\end{tabular}

\section{Risk of bias}

\begin{tabular}{lll}
\hline Bias & Authors' judgement & Support for judgement \\
\hline $\begin{array}{l}\text { Random sequence genera- } \\
\text { tion (selection bias) }\end{array}$ & Unclear risk & "randomised" \\
\hline $\begin{array}{l}\text { Allocation concealment } \\
\text { (selection bias) }\end{array}$ & Low risk & $\begin{array}{l}\text { "[Randomization }] \text { was performed with pre-prepared sealed opaque envelopes } \\
\text { containing details on group allocation. The patients opened the envelopes } \\
\text { themselves so that their allocation to IP or UC was revealed to them without } \\
\text { the prior knowledge of the study investigators". }\end{array}$ \\
\hline
\end{tabular}

Blinding of outcome as- Unclear risk Blinding not described.

sessment (detection bias)

All outcomes

Incomplete outcome data High risk

$17.8 \%$ lost to follow up, no description of withdrawals or dropouts.

(attrition bias)

All outcomes

Selective reporting (re- Low risk porting bias)

All outcomes were reported at all time points. 
VHSG 2003 (Continued)
Groups balanced at base-
Low risk
"none of the intergroup differences were significant" line

Intention-to-treat analysis High risk

conducted

\section{Groups received same High risk} treatment (apart from the intervention)
No.

Patients in the IP group were subjected to a six-week period of "heart school".... this multidisciplinary cardiac rehabilitation comprised lifestyle intervention, such as dietary advice, smoking cessation, physical activity counselling, risk factor management, psychosocial management and health education...."

Maximum follow up: 6 months

Participants

Inclusion criteria: Inclusion criteria comprised a documented diagnosis of acute MI, the ability to speak and read Chinese, a return to living at home after hospital discharge, availability for telephone follow-up, and availability for meetings after hospital discharge.

Exclusion criteria: Exclusion criteria comprised a known history of major psychiatric illness, pre-existing mobility problems, unstable angina, severe complications such as uncontrolled arrhythmias or heart failure, and other conditions that could be aggravated by exercise, such as a resting systolic blood pressure $(\mathrm{BP})>200 \mathrm{mmHg}$ or a resting diastolic $\mathrm{BP}>110 \mathrm{mmHg}$.

N Randomised: total: 160; intervention: 80; comparator: 80

Diagnosis (\% of pts): Acute AMI: $100 \%$

Age (mean \pm SD): intervention: $57.3( \pm 8.6)$; comparator: $58.3( \pm 10.4)$

Percentage male: intervention: $85.3 \%$; comparator: $81.5 \%$

Ethnicity: NR

Interventions

Intervention: A 6-week, home-based rehabilitation programme using a self-help heart manual given to the rehab patients just before discharge from hospital The manual was similar to the UK heart manual but incorporated appropriate sociocultural components such as tai chi, qi gong, and Chinese diet.

Section 1 consists of 6 weekly topics on health education.

Section 2 answers commonly asked questions about medication, $\mathrm{PCl}$, anxiety and depression etc.

Section 3 presents information on normal values of cardiac physiological risk parameters.

The rehabilitation group received the manual and the introductory session in addition to usual care.

The exercise component of the manual is not described in this paper, and there is no reference to its description elsewhere.

Components: exercise plus education.

Setting: home.

\section{Aerobic exercise:}


Modality: not described.

Length of session: not described.

Frequency: not described.

Intensity: not described.

Resistance training included? not described.

Total duration: not described.

Co-interventions: Patients in both groups were telephoned by the principal researcher 3 weeks after discharge. For the rehabilitation group, the researcher checked the patient's progress, encouraged adherence to exercise, and helped solve problems that had arisen using the manual. This consultation lasted approximately 30 minutes, with contact designed to promote patient confidence and self-management, and minimise dependency and the possibility that the nurse could influence outcomes.

Comparator: The usual care group received instructions on taking medications, information leaflets about cardiac risk factors, a healthy diet, and smoking cessation, and a follow-up appointment.

Co-interventions: The researcher devoted an equal amount of time to telephone contact with the control group, giving general advice on any problems encountered and encouraging and supporting appropriate actions.

\begin{tabular}{ll}
\hline Outcomes & Mortality, HRQL. \\
\hline Source of funding & NR \\
\hline Conflicts of interest & NR \\
\hline Notes & $\begin{array}{l}\text { Baseline characteristics only reported for those followed up until } 6 \text { months i.e. } 68 \text { in intervention group } \\
\text { and } 65 \text { in usual care group. }\end{array}$
\end{tabular}

\section{Risk of bias}

\begin{tabular}{|c|c|c|}
\hline Bias & Authors' judgement & Support for judgement \\
\hline $\begin{array}{l}\text { Random sequence genera- } \\
\text { tion (selection bias) }\end{array}$ & Low risk & $\begin{array}{l}\text { "Patients ........were enrolled and assigned to either the experimental or the } \\
\text { control group, using a computer-generated random number". }\end{array}$ \\
\hline $\begin{array}{l}\text { Allocation concealment } \\
\text { (selection bias) }\end{array}$ & Unclear risk & Allocation concealment was not described. \\
\hline $\begin{array}{l}\text { Blinding of outcome as- } \\
\text { sessment (detection bias) } \\
\text { All outcomes }\end{array}$ & High risk & $\begin{array}{l}\text { "the absence of a blinded condition may threaten its internal validity. In addi- } \\
\text { tion, the } \\
\text { principal researcher played the role of both intervener and outcome assessor, } \\
\text { which may have influenced participants to provide desired answers, and so in- } \\
\text { terviewer bias cannot be excluded" }\end{array}$ \\
\hline
\end{tabular}

$\begin{array}{ll}\begin{array}{l}\text { Incomplete outcome data } \\ \text { (attrition bias) }\end{array} & \text { Low risk } \\ \text { All outcomes } & 12 / 80(15 \%) \text { lost from intervention group. } \\ & 15 / 80(18.8 \%) \text { lost from the control group. }\end{array}$

Numbers and reasons were given and were similar for both groups.

\begin{tabular}{lll}
\hline $\begin{array}{l}\text { Selective reporting (re- } \\
\text { porting bias) }\end{array}$ & Low risk & All outcomes described were reported for all time points. \\
\hline $\begin{array}{l}\text { Groups balanced at base- } \\
\text { line }\end{array}$ & Low risk & $\begin{array}{l}\text { "Demographic and clinical characteristics of patients in both groups were } \\
\text { compared (Table 1), and no statistically significant differences were found. }\end{array}$ \\
\hline
\end{tabular}

Exercise-based cardiac rehabilitation for coronary heart disease (Review) 

tically significant differences were found".

\begin{tabular}{|c|c|c|}
\hline $\begin{array}{l}\text { Intention-to-treat analysis } \\
\text { conducted }\end{array}$ & Low risk & "All data were analyzed in terms of intention to treat" \\
\hline $\begin{array}{l}\text { Groups received same } \\
\text { treatment (apart from the } \\
\text { intervention) }\end{array}$ & Low risk & $\begin{array}{l}\text { "Patients in both groups were telephoned by the principal researcher } 3 \text { weeks } \\
\text { after discharge........The researcher devoted an equal amount of time to tele- } \\
\text { phone contact with the control group, giving general advice on any problems } \\
\text { encountered and encouraging and supporting appropriate actions." }\end{array}$ \\
\hline
\end{tabular}

\section{West 2012}

\begin{tabular}{ll}
\hline Methods & Study design: Multicentre RCT (14 sites) \\
& Country: England and Wales, UK \\
& Dates patients recruited: August 1997 to April 2000 \\
& Maximum follow up: 7 to 9 years \\
\hline Participants & $\begin{array}{l}\text { Inclusion criteria: Admission to hospital with a principal primary diagnosis of acute MI (two of the } \\
\text { three standard criteria 'typical history', electrocardiographic features and cardiac enzymes), dis- } \\
\text { charged home within } 28 \text { days, local resident and able to give informed consent with no age or gender } \\
\text { restrictions. }\end{array}$
\end{tabular}

Exclusion criteria: Physical frailty, mental confusion, serious co-existing disease, communication difficulty, previous cardiac rehabilitation and discharged to hospice or another hospital.

N Randomised: total: 1813; intervention: 903; comparator: 910

Diagnosis (\% of pts): Acute MI: $100 \%$

Age (mean \pm SD): intervention: $64.2 \pm 11.2$; comparator: $64.7 \pm 10.9$

Percentage male: intervention: $72.6 \%$; comparator: $74.4 \%$

Ethnicity: NR

Interventions

Intervention: Exercise training was the largest component, typically occupying half of the available time including warm up and cool down, and used exercise equipment in physiotherapy gyms. Relaxation was primarily physical following 'cooling down' from exercise with little or no 'stress management' training.

Components: exercise plus education plus psych.

Setting: centre-based supervised programmes which varied centre.

\section{Aerobic exercise:}

Modality: varied by centre.

Length of session: averaged 20 hours over 6-8 weeks.

Frequency: weekly or bi-weekly.

Intensity: NR

Resistance training included? NR

Total duration: 6-8 weeks. 
West 2012 (Continued)

Co-interventions: The programmes comprised exercise training, health education about heart, heart disease, risk factors and treatment, counselling for recovery and advice for long-term secondary prevention. All involved at least one other discipline (exercise physiologist, dietician, pharmacist, health promotion specialist, psychologist, counsellor, social worker, physician and/or cardiologist).

Comparator: All patients in the trial (and in the 'elective hospitals' comparison) had similar care in all respects other than referral to cardiac rehabilitation, receiving available explanatory booklets, being advised to see their general practitioner (GP) and attend routine outpatient follow-up, with referral for further cardiac investigations or interventions as appropriate.

Co-interventions: none described.

\begin{tabular}{ll}
\hline Outcomes & Mortality, MI, revascularisations, hospitalisation, HRQL. \\
\hline Source of funding & NHS Research and Development Programme (northern region) and the Heart research fund for Wales. \\
\hline Conflicts of interest & None declared. \\
\hline Notes & $\begin{array}{l}\text { An additional } 331 \text { patients were entered in two matched pairs of 'elective rehabilitation' and 'elective } \\
\text { control' hospitals; } 197 \text { to rehabilitation and 134 to control. }\end{array}$ \\
\hline
\end{tabular}

\section{Risk of bias}

\begin{tabular}{|c|c|c|}
\hline Bias & Authors' judgement & Support for judgement \\
\hline $\begin{array}{l}\text { Random sequence genera- } \\
\text { tion (selection bias) }\end{array}$ & Unclear risk & "Patients were randomised centrally" - it does not state how. \\
\hline $\begin{array}{l}\text { Allocation concealment } \\
\text { (selection bias) }\end{array}$ & Low risk & $\begin{array}{l}\text { "Patients were randomised centrally on a preset protocol, daily and blind as } \\
\text { to entry characteristics and baseline measures, .....The names of those ran- } \\
\text { domised to rehabilitation were passed to the local programme coordinator". }\end{array}$ \\
\hline $\begin{array}{l}\text { Blinding of outcome as- } \\
\text { sessment (detection bias) } \\
\text { All outcomes }\end{array}$ & Low risk & Secondary outcomes were assessed at 1 year....blind to rehabilitation status". \\
\hline $\begin{array}{l}\text { Incomplete outcome data } \\
\text { (attrition bias) } \\
\text { All outcomes }\end{array}$ & Low risk & $\begin{array}{l}5 \% \text { lost to FU from each group ( } 2 \text { year interviews); "follow-up interviews were } \\
\text { completed in } 95 \% \text { of surviving patients in both groups" }\end{array}$ \\
\hline $\begin{array}{l}\text { Selective reporting (re- } \\
\text { porting bias) }\end{array}$ & Low risk & All outcomes reported for all time points. \\
\hline $\begin{array}{l}\text { Groups balanced at base- } \\
\text { line }\end{array}$ & Low risk & $\begin{array}{l}\text { "At baseline, patients randomised to rehabilitation and controls were well } \\
\text { matched on personal characteristics, clinical histories and lifestyle habits." }\end{array}$ \\
\hline $\begin{array}{l}\text { Intention-to-treat analysis } \\
\text { conducted }\end{array}$ & Low risk & Analysis is by 'intention to treat'. \\
\hline $\begin{array}{l}\text { Groups received same } \\
\text { treatment (apart from the } \\
\text { intervention) }\end{array}$ & High risk & $\begin{array}{l}\text { "The programmes comprised exercise training, health education about heart, } \\
\text { heart disease, risk factors and treatment, counselling for recovery and advice } \\
\text { for long-term secondary prevention". }\end{array}$ \\
\hline
\end{tabular}

WHO 1983

Methods Study design: Multicentre RCT (24 sites; 12 centres accepted for meta analysis.)


WHO 1983 (Continued)

Country: Multiple European countries

Dates patients recruited: 1972 to 1974

Maximum follow up: 3 years

Patients randomised on discharge from hospital.

Participants

Inclusion criteria: Men < 65 yrs with first or consecutive MI.

Exclusion criteria: NR

N Randomised: total: 3184; intervention: 1655; comparator: 1529

Diagnosis (\% of pts): MI: $100 \%$

Age (years): intervention: 52.3; comparator:53.5

Percentage male: intervention: $100 \%$; comparator: $100 \%$

Ethnicity: NR

Interventions

Intervention: Comprehensive programme dependent on local provision. Physical training was not compulsory but was strongly recommended.

Components: exercise, education and psychosocial support.

Setting: centre.

Aerobic exercise:

Modality: NR

Length of session: NR

Frequency: NR

Intensity: NR

\section{Resistance training included? NR}

Total duration: 6 weeks.

Co-interventions: The intervention had to be at the highest possible level available locally. It had to be comprehensive, with the aim of improving health and reducing IHD risk. It comprised treatment of heath failure, arterial hypertension etc, risk factor modification, weight loss and improving physical working capacity.

Comparator: usual care.

Co-interventions: none described.

Outcomes Total mortality, CVD, CHD \& sudden death.

Fatal \& non fatal re-infarction.

Source of funding WHO Regional Office for Europe and the Ministries of Health of the participating member states.

Conflicts of interest NR

Notes Methodological problems with the execution of the study allowed only death and reinfarction to be
successfully used as endpoints.

\section{Risk of bias}


WHO 1983 (Continued)

Bias Authors' judgement Support for judgement

Random sequence genera- High risk tion (selection bias)
"Patients were randomised at admission......by means of random number tables".

However, "Only 12 centres out of the 24 seemed to have achieved proper randomisation in their groups of $\mathrm{R}$ and C patients"

\begin{tabular}{lll}
\hline $\begin{array}{l}\text { Allocation concealment } \\
\text { (selection bias) }\end{array}$ & Unclear risk & Not reported. \\
\hline $\begin{array}{l}\text { Blinding of outcome as- } \\
\text { sessment (detection bias) } \\
\text { All outcomes }\end{array}$ & Unclear risk & Blinding not described. \\
\hline
\end{tabular}

Incomplete outcome data Unclear risk

No description of withdrawals or dropouts. Varied greatly from site to site.

(attrition bias)

All outcomes

Selective reporting (re- Low risk $\quad$ All clinical endpoints were reported for 12, 24 and 36 month follow-ups.
porting bias)

\begin{tabular}{lll}
\hline $\begin{array}{l}\text { Groups balanced at base- } \\
\text { line }\end{array}$ & High risk & $\begin{array}{l}\text { "Only } 12 \text { centres out of the } 24 \text { seemed to have achieved proper randomisation } \\
\text { in their groups of intervention and control patients". }\end{array}$ \\
\hline $\begin{array}{l}\text { Intention-to-treat analysis } \\
\text { conducted }\end{array}$ & Unclear risk & Unclear. \\
\hline $\begin{array}{l}\text { Groups received same } \\
\text { treatment (apart from the } \\
\text { intervention) }\end{array}$ & High risk & $\begin{array}{l}\text { "The intervention had to be at the highest possible level available locally. It } \\
\text { had to be comprehensive...it comprised treatment of heart failure; stopping } \\
\text { smoking; reducing alcohol consumption; normalising serum lipid levels; losing } \\
\text { weight and improving physical working capacity.....physical training was not } \\
\text { compulsory but strongly recommended........" }\end{array}$ \\
\hline
\end{tabular}

Wilhelmsen 1975

Study design: Single centre RCT
Country: Sweden
Dates patients recruited: $1968-1970$
Maximum follow up: 5 years
Patients randomised on discharge.

Participants

Inclusion criteria: All patients born in 1913 or later who suffered a MI during the period 1968-1970 and were discharged alive from the hospital.

Exclusion criteria: none described.

N Randomised: total: 315; intervention: 158; comparator: 157

Diagnosis (\% of pts): MI: $100 \%$

Age (years): intervention: 50.6; comparator: 50.6

Percentage male: intervention: $87 \%$; comparator: $90 \%$ 
Wilhelmsen 1975 (Continued)

\section{Ethnicity: NR}

Interventions

Intervention: The training programme started 3 months after the MI. The programme at the hospital consisted of three supervised half-hour training sessions a week. It included dynamic work, such as calisthenics, cycling, and running in an interval programme with individualised intensity. If a patient found it difficult to attend the hospital for training then individualised programmes were developed for training at home or in the workplace.

Components: exercise.

Setting: supervised in a centre.

\section{Aerobic exercise:}

Modality: e.g. cycling, running.

Length of session: $1 / 2$ hour.

Frequency: three times a week.

Intensity: $144 \pm 18$ beats/min; $80 \%$ of their heart rate increasing capacity (if no sign of cardiac limitation); $136 \pm 19$ beats/min in mean highest training heart rate (if limited by angina pectoris).

Resistance training included? Calisthenics.

Total duration: NR - see notes below.

Co-interventions: At discharge from hospital all patients were given general recommendations about gradually increasing physical activity during the convalescence period.

Comparator: usual care.

Co-interventions: as above.

Outcomes Mortality, re-infarction.

Source of funding NR

Conflicts of interest NR

Notes 1 year post-MI, only $39 \%$ of those who started training were training at the hospital. A further $21 \%$ trained at home or at work.

\section{Risk of bias}

\begin{tabular}{lll}
\hline Bias & Authors' judgement & Support for judgement \\
\hline $\begin{array}{l}\text { Random sequence genera- } \\
\text { tion (selection bias) }\end{array}$ & Low risk & "By the use of a random number table the patients were allocated..." \\
\hline $\begin{array}{l}\text { Allocation concealment } \\
\text { (selection bias) }\end{array}$ & Unclear risk & Not reported. \\
\hline $\begin{array}{l}\text { Blinding of outcome as- } \\
\text { sessment (detection bias) } \\
\text { All outcomes }\end{array}$ & Low risk & $\begin{array}{l}\text { "The exercise test } 1 \text { yr after the Ml followed the same protocol but was con- } \\
\text { ducted by another physician, who did not know if the patients belonged to the } \\
\text { experimental or the control group". }\end{array}$ \\
\hline $\begin{array}{l}\text { Incomplete outcome data } \\
\text { (attrition bias) } \\
\text { All outcomes }\end{array}$ & Low risk & No losses to follow up for clinical events. \\
\hline
\end{tabular}


Wilhelmsen 1975 (Continued)

Selective reporting (re- Unclear risk Outcomes to be collected were not clearly described in the methods. porting bias)

Groups balanced at base- High risk line

\begin{abstract}
"Despite the fact that the randomization was done according to a random number table, there were slightly more patients with a history of hypertension, previous MI, treatment with digitalis prior to the MI, and also with high physical activity during leisure time in the control group than in the experimental group. Dyspnea during the acute phase was more common in the experimental group than in the control group. Body weight and systolic blood pressure were slightly lower in the control group than in the experimental group 3 months after the MI".
\end{abstract}

\begin{tabular}{lll}
\hline $\begin{array}{l}\text { Intention-to-treat analysis } \\
\text { conducted }\end{array}$ & High risk \\
\hline $\begin{array}{l}\text { Groups received same } \\
\text { treatment (apart from the } \\
\text { intervention) }\end{array}$ & Low risk & $\begin{array}{l}\text { "... the two patient groups were treated in a uniform manner by three physi- } \\
\text { cians, and all possible precautions were taken to standardize the follow-up } \\
\text { and treatment with the exception of the training programme." }\end{array}$
\end{tabular}

\begin{tabular}{|c|c|}
\hline Methods & $\begin{array}{l}\text { Study design: Single centre RCT } \\
\text { Country: China } \\
\text { Dates patients recruited: NR } \\
\text { Maximum follow up: } 2 \text { years }\end{array}$ \\
\hline Participants & $\begin{array}{l}\text { Inclusion criteria: Obese patients with } \mathrm{CHD} \text { who had either recent } \mathrm{AMI} \text { or had undergone elective } \mathrm{PCl} \\
\text { in last } 6 \text { wks. } \\
\text { Exclusion criteria: Postinfarction angina without revascularisation procedures, significant valvular } \\
\text { stenosis, active pericarditis or myocarditis, severe uncontrolled hypertension, physical problems that } \\
\text { precluded exercise training, cognitive impairment, malignancies that limited life span to } 1 \text { year. } \\
\text { N Randomised: total: } 112 \text {; intervention: } 72 \text {; comparator: } 40 \\
\text { Diagnosis (\% of pts): } \\
\text { AMI: } 64 \% \\
\text { PCI: } 36 \% \\
\text { Age (mean } \pm \text { SD): intervention: } 62.3 \pm 11.2 \text {; comparator: } 61.2 \pm 10.2 \\
\text { Percentage male: intervention: } 82 \% \text {; comparator: } 75 \% \\
\text { Ethnicity: NR }\end{array}$ \\
\hline
\end{tabular}

Interventions

Intervention:

Phase 1 was an inpatient ambulatory programme that lasted 7 to 14 days.

Phase 2 was a 16-session, twice weekly, outpatient exercise and education programme lasting for 8 weeks. Each session included 1 hour of education class followed by 2 hours of exercise training. The first hour of training focused on aerobic CV training with a target intensity of $65 \%$ to $85 \%$ of maximal aerobic capacity. This included treadmill, ergometry, rowing, stepper, arm ergometry, and dumbbell and weight training. The next hour was conducted by an occupational therapist in which domiciliary or vocational environment-focused training was performed.

Phase 3 was a community-based home exercise programme for another 6 months. 
Yu 2003 (Continued)

Components: exercise and education.

Setting: centre followed by home.

\section{Aerobic exercise:}

Modality: treadmill, ergometry, rowing, stepper, arm ergometry, and dumbbell.

Length of session: 2 hours (for 8 weeks) then unspecified at home.

Frequency: twice a week (for 8 weeks) then unspecified at home.

Intensity: $65 \%$ to $85 \%$ of maximal aerobic capacity.

Resistance training included? Weight training.

Total duration: $81 / 2$ months.

Co-interventions: Phase 4 was a long-term follow-up programme until the end of 2 years, which included half-yearly monitoring of lipid profiles, and again stressed the importance of regular exercise and risk factor modification.

Comparator: conventional medical therapy.

Co-interventions: The control group attended a 2-hour talk that explained CHD, the importance of risk factor modification, and potential benefits of physical activity, but without undergoing an outpatient exercise training programme.

\begin{tabular}{ll}
\hline Outcomes & HRQL: 3F-36 at $8 \& 24$ months. \\
\hline Source of funding & NR \\
\hline Conflicts of interest & NR \\
\hline
\end{tabular}

Notes

\section{Risk of bias}

\begin{tabular}{lll}
\hline Bias & Authors' judgement & Support for judgement \\
\hline $\begin{array}{l}\text { Random sequence genera- } \\
\text { tion (selection bias) }\end{array}$ & Unclear risk & Not reported. \\
\hline $\begin{array}{l}\text { Allocation concealment } \\
\text { (selection bias) }\end{array}$ & Unclear risk & Not reported. \\
\hline $\begin{array}{l}\text { Blinding of outcome as- } \\
\text { sessment (detection bias) } \\
\text { All outcomes }\end{array}$ & Unclear risk & Blinding not described. \\
\hline $\begin{array}{l}\text { Incomplete outcome data } \\
\text { (attrition bias) } \\
\text { All outcomes }\end{array}$ & Low risk & All patients accounted for. \\
\hline $\begin{array}{l}\text { Selective reporting (re- } \\
\text { porting bias) }\end{array}$ & Low risk & All outcomes were reported at all time points. \\
\hline $\begin{array}{l}\text { Groups balanced at base- } \\
\text { line }\end{array}$ & Low risk & $\begin{array}{l}\text { There was no difference in age, gender, disease demographics, and medica- } \\
\text { tions between the CRPP and control groups. }\end{array}$ \\
\hline
\end{tabular}


Yu 2003 (Continued)

Intention-to-treat analysis High risk No.
conducted

Groups received same treatment (apart from the intervention)
High risk

Cardiac rehabilitation and prevention program (CRPP) consists of exercise and education programme.

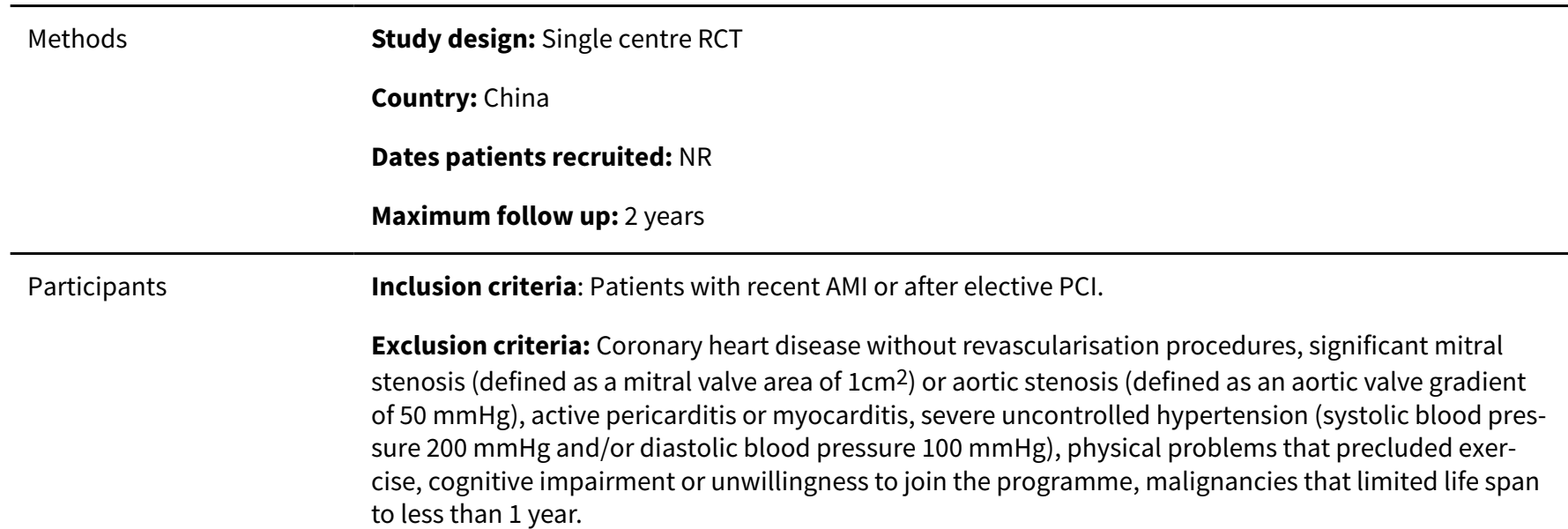

N Randomised: total: 269; intervention: 181; comparator: 88

\section{Diagnosis (\% of pts):}

AMI: $72 \%$

PCI: $28 \%$

Age (mean \pm SD): intervention: $64 \pm 11$; comparator: $64 \pm 11$

Percentage male: intervention: $76 \%$; comparator: $75 \%$ Ethnicity: NR

\section{Intervention:}

Phase 1 was an inpatient ambulatory programme that lasted 7 to 14 days.

Phase 2 was a 16 -session, twice weekly, outpatient exercise and education programme lasting for 8 weeks. Each session included 1 hour of education class followed by 2 hours of exercise training. The first hour of training focused on aerobic CV training with a target intensity of $65 \%$ to $85 \%$ of maximal aerobic capacity. This included treadmill, ergometry, rowing, stepper, arm ergometry, and dumbbell and weight training. The next hour was conducted by an occupational therapist in which domiciliary or vocational environment-focused training was performed.

Phase 3 was a community-based home exercise programme for another 6 months.

Components: exercise and education.

Setting: centre followed by home.

\section{Aerobic exercise:}

Modality: treadmill, ergometry, rowing, stepper, arm ergometry, and dumbbell.

Length of session: 2 hours (for 8 weeks) then unspecified at home. 
Yu 2004 (Continued)

Frequency: twice a week (for 8 weeks) then unspecified at home.

Intensity: $65 \%$ to $85 \%$ of maximal aerobic capacity.

Resistance training included? Weight training.

Total duration: $81 / 2$ months.

Co-interventions: Phase 4 was a long-term follow-up programme until the end of 2 years, which included half-yearly monitoring of lipid profiles, and again stressed the importance of regular exercise and risk factor modification.

Comparator: conventional medical therapy.

Co-interventions: The control group attended a 2-hour talk that explained CHD, the importance of risk factor modification, and potential benefits of physical activity, but without undergoing an outpatient exercise training programme.

Outcomes Total mortality, HRQL, costs.

\begin{tabular}{ll}
\hline Source of funding & Health Care \& Promotion Fund Committee of Hong Kong. \\
\hline Conflicts of interest & $\begin{array}{l}\text { "No commercial party having a direct financial interest in the results of the research supporting this ar- } \\
\text { ticle has or will confer a benefit upon the authors(s) or upon any organization with which the author(s) } \\
\text { is/are associated." }\end{array}$ \\
\hline
\end{tabular}

Notes

\section{Risk of bias}

\begin{tabular}{|c|c|c|}
\hline Bias & Authors' judgement & Support for judgement \\
\hline $\begin{array}{l}\text { Random sequence genera- } \\
\text { tion (selection bias) }\end{array}$ & Unclear risk & "randomized" \\
\hline $\begin{array}{l}\text { Allocation concealment } \\
\text { (selection bias) }\end{array}$ & Unclear risk & Not reported. \\
\hline $\begin{array}{l}\text { Blinding of outcome as- } \\
\text { sessment (detection bias) } \\
\text { All outcomes }\end{array}$ & Unclear risk & Blinding not described. \\
\hline $\begin{array}{l}\text { Incomplete outcome data } \\
\text { (attrition bias) } \\
\text { All outcomes }\end{array}$ & High risk & $24 \%$ lost to follow up, no description of withdrawals or dropouts. \\
\hline $\begin{array}{l}\text { Selective reporting (re- } \\
\text { porting bias) }\end{array}$ & Low risk & All outcomes reported at all time points. \\
\hline $\begin{array}{l}\text { Groups balanced at base- } \\
\text { line }\end{array}$ & Low risk & $\begin{array}{l}\text { There was no difference in age, sex, and other clinical parameters between the } \\
\text { CRPP and control groups. }\end{array}$ \\
\hline $\begin{array}{l}\text { Intention-to-treat analysis } \\
\text { conducted }\end{array}$ & High risk & No. \\
\hline $\begin{array}{l}\text { Groups received same } \\
\text { treatment (apart from the } \\
\text { intervention) }\end{array}$ & High risk & $\begin{array}{l}\text { Cardiac rehabilitation and prevention program (CRPP) consists of exercise and } \\
\text { education programme. }\end{array}$ \\
\hline
\end{tabular}


Zwisler 2008

\begin{tabular}{ll} 
Methods & Study design: Single centre RCT \\
Country: Denmark \\
Dates patients recruited: January 2000 to March 2003 \\
Maximum follow up: 1 year \\
\hline Inclusion criteria: Participants with congestive heart failure (12\%), *ischemic heart disease (58\%) or \\
high risk of ischemic heart disease (30\%). \\
Exclusion criteria: Mental or social problems, severe illness, living in nursing home, unable to speak \\
Danish \\
*Total Randomised (with IHD): total: $446 ;$ intervention: 227 ; comparator: 219 \\
Diagnosis (\% of pts): *Ischemic heart disease: $100 \%$ \\
Age (years): intervention: $67 ;$ comparator: 67 \\
Percentage male: intervention: $64 \%$; comparator: $63 \%$ \\
Ethnicity: NR
\end{tabular}

Interventions

Intervention: A 6-week intensive CR programme including 12 exercise training sessions.

Components: exercise, education and psychosocial support.

Setting: centre.

Aerobic exercise:

Modality: NR

Length of session: NR

Frequency: twice a week.

Intensity: NR

Resistance training included? NR

Total duration: 6 weeks.

Co-interventions: Standardised CR programme which was individually tailored and carried out by a multidisciplinary team, included patient education, dietary counselling, smoking cessation, psychosocial support, risk factor management, and clinical assessment.

Comparator: usual care.

Co-interventions: none described.

Outcomes Total mortality, MI, CABG, PCI, health-related quality of life: SF-36 at 1-yr follow up.

Source of funding Copenhagen Hospital Corporation Research Council, Danish Heart Foundation, Danish Pharmacy Foundation of 1991, Danish Research Council, Danish Center for Evaluation and Health Technology Assessment, Denmark's Ministry of the Interior and Health, Development Fund of Copenhagen County, Villadsen Family Foundation, Eva and Henry Frænkel's Memorial Foundation, Builder LP Christensen's Foundation, Danish Animal Protection Foundation, Bristol Meyers Squibb, Merck Sharp and Dohme, AstraZeneca, The Copenhagen Trial Unit, and Bispebjerg Hospital. 
Zwisler 2008 (Continued)

Notes Outcomes of interest for the IHD population were kindly provided by the authors of this study.

\section{Risk of bias}

\begin{tabular}{|c|c|c|}
\hline Bias & Authors' judgement & Support for judgement \\
\hline $\begin{array}{l}\text { Random sequence genera- } \\
\text { tion (selection bias) }\end{array}$ & Low risk & $\begin{array}{l}\text { "The Copenhagen Trial Unit computer generated the allocation sequence and } \\
\text { provided central secretary-staffed telephone randomization". }\end{array}$ \\
\hline $\begin{array}{l}\text { Allocation concealment } \\
\text { (selection bias) }\end{array}$ & Low risk & $\begin{array}{l}\text { "The essential patient data were registered, and the result of the randomiza- } \\
\text { tion as delivered to the research nurse, who informed the CCR team and the } \\
\text { patient about the allocation". }\end{array}$ \\
\hline $\begin{array}{l}\text { Blinding of outcome as- } \\
\text { sessment (detection bias) } \\
\text { All outcomes }\end{array}$ & Low risk & $\begin{array}{l}\text { "The ... team collected secondary outcome measures blinded to intervention } \\
\text { at baseline and without blinding at } 12 \text { months. An independent statistician an- } \\
\text { alyzed the primary outcome measure blinded to intervention arm. }\end{array}$ \\
\hline $\begin{array}{l}\text { Incomplete outcome data } \\
\text { (attrition bias) } \\
\text { All outcomes }\end{array}$ & Low risk & All IHD patients accounted for. \\
\hline $\begin{array}{l}\text { Selective reporting (re- } \\
\text { porting bias) }\end{array}$ & Low risk & All outcomes reported at all time points. \\
\hline $\begin{array}{l}\text { Groups balanced at base- } \\
\text { line }\end{array}$ & Low risk & $\begin{array}{l}\text { "The patients were well matched at entry both overall (Table I) and in the } 3 \\
\text { subgroups (data not shown)." }\end{array}$ \\
\hline $\begin{array}{l}\text { Intention-to-treat analysis } \\
\text { conducted }\end{array}$ & Low risk & Yes. \\
\hline $\begin{array}{l}\text { Groups received same } \\
\text { treatment (apart from the } \\
\text { intervention) }\end{array}$ & High risk & $\begin{array}{l}\text { "Comprehensive cardiac rehabilitation.....included patient education, exercise } \\
\text { training sessions, dietary counseling, smoking cessation, psychosocial sup- } \\
\text { port, risk factor management, and clinical assessment". }\end{array}$ \\
\hline
\end{tabular}

\section{List of acronyms used in the Characteristics of included studies}

ACS: acute coronary syndrome

AMI: acute myocardial infarction

CABG: coronary artery bypass graft

CAD: coronary artery disease

CHD: coronary heart disease

CHF: coronary heart failure

CR: cardiac rehabilitation

CV: cardiovascular

CVD: cardiovasular disease

ECG: electrocardiogram

ET: exercise training

HR: heart rate

HRQL: health related quality of life

IHD: ischemic heart disease

$\mathrm{Kpm} / \mathrm{min}$ : kilopond meters per minutes

LVEF: left ventricular ejection fraction

METS: metabolic equivalents

MI: myocardial infarction

NR: not reported

$\mathrm{PCl}$ : percutaneous coronary intervention

PTCA: percutaneous transluminal coronary angioplasty

pts: participants

PWC: physical work capacity 
$\mathrm{RCT}$ : randomised controlled trial

RTW: return to work

STEMI: ST segment elevation myocardial infarction

$\mathrm{V}_{2}$ max: maximum oxygen uptake

WHO: World Health Organisation

Characteristics of excluded studies [ordered by study ID]

\begin{tabular}{|c|c|}
\hline Study & Reason for exclusion \\
\hline Agren 1989 & Improper method of randomisation (based on date of birth). \\
\hline Andersson 2010 & Comparator received exercise. \\
\hline Aronov 2006 & No useful outcome data reported. \\
\hline Asbury 2012 & Follow up only 16 weeks. \\
\hline Astengo 2010 & No outcomes of interest reported. \\
\hline Ballantyne 1982 & No useful outcome data reported \\
\hline Belardinelli 2007 & $\begin{array}{l}\text { Abstract only with incomplete reporting of study characteristics and outcome data. Full trial re- } \\
\text { port not published. }\end{array}$ \\
\hline Bilinska 2010 & Follow up only 6 weeks. \\
\hline Bilinska 2013 & Follow up only 6 weeks. \\
\hline Björntorp 1972 & Not a randomised study - participants divided alternately after admission. \\
\hline Blumenthal 1997 & Control group was not randomised, but selected on geographical basis. \\
\hline Bourke 2010 & Trial terminated early due to poor recruitment. \\
\hline Bubnova 2014 & No outcomes of interest reported. \\
\hline Busch 2012 & Comparator received exercise. \\
\hline Butler 2009 & Participants had already received rehabilitation. \\
\hline Bär 1992 & $\begin{array}{l}\text { Method of randomisation was inadequate; of a study population of } 265 \text { across } 5 \text { centres only one } \\
\text { centre randomised their patients, leaving a control group of } 50 \text { and an intervention group of } 215 .\end{array}$ \\
\hline Carlsson 1997 & No useful outcome data reported. \\
\hline Chang 2010 & No outcomes of interest reported. \\
\hline Chatian 2014 & No outcomes of interest reported and follow up only 3 months. \\
\hline Chow 2012 & Intervention does not contain exercise. \\
\hline Edstrom-Pluss 2009 & Comparator received exercise. \\
\hline Espinosa 2004 & Not an RCT. \\
\hline Gao 2007 & No useful outcome data reported. Duration of follow-up not reported. \\
\hline
\end{tabular}




\begin{tabular}{|c|c|}
\hline Study & Reason for exclusion \\
\hline Ghashghaei 2012 & Not an RCT. \\
\hline Giallauria 2009 & No outcomes of interest. \\
\hline Giallauria 2012 & No outcomes of interest. \\
\hline Giallauria 2013 & No outcomes of interest. \\
\hline Giannuzzi 2008 & $\begin{array}{l}\text { All patients (treatment and control) participated in } 3 \text { to } 6 \text { week cardiac rehabilitation pro- } \\
\text { gramme (including supervised exercise sessions) prior to randomisation. Control group was not } \\
\text { "usual care". }\end{array}$ \\
\hline Gielen 2003 & No useful outcome data reported. \\
\hline На 2011 & Not an RCT. \\
\hline Haddadzadeh 2011 & Follow up only 12 weeks. \\
\hline Hansen 2009 & Not an RCT. \\
\hline Hansen 2010 & Not an RCT. \\
\hline Hanssen 2009 & Intervention does not contain exercise. \\
\hline Hawkes 2009 & Intervention does not contain exercise. \\
\hline Heldal 2000 & No useful outcome data reported. \\
\hline Houle 2011 & No outcomes of interest. \\
\hline Huerre 2010 & Not an RCT. \\
\hline Jiang 2007 & No useful outcome data reported \\
\hline Karpova 2009 & Not an RCT. \\
\hline Kavanagh 1973 & No outcomes of interest. \\
\hline Kentala 1972 & Not an RCT. \\
\hline Kim 2011 & Not an RCT. \\
\hline Kim 2012 & Not an RCT. \\
\hline Kim 2013 & Not an RCT. \\
\hline Krachler 1997 & No useful outcome data reported. \\
\hline Kubilius 2012 & Not an RCT. \\
\hline Lee 2013 & Not an RCT. \\
\hline Li 2004 & Follow up $<6$ months. \\
\hline Liao 2003 & Follow-up too short ( 3 to 4 weeks) and no useful outcome data reported. \\
\hline
\end{tabular}




\begin{tabular}{|c|c|}
\hline Study & Reason for exclusion \\
\hline Lie 2009 & Intervention does not contain exercise. \\
\hline Mameletzi 2011 & No outcomes of interest. \\
\hline Mandic 2013 & Not an RCT. \\
\hline Martinez 2011 & No outcomes of interest. \\
\hline Mayer-Berger 2014 & Comparator received exercise. \\
\hline Mezey 2008 & Not an RCT. \\
\hline Mohammed 2012 & No outcomes of interest. \\
\hline Moholdt 2012a & Comparator received exercise. \\
\hline Moholdt 2012b & Comparator received exercise. \\
\hline Molino-Lova 2013 & Participants had already received rehabilitation. \\
\hline Murphy 2012 & Partcipants did not have CHD. \\
\hline Pater 2000 & Authors did not respond to repeated requests for study update. \\
\hline Pedersen 2013 & Comparator received exercise. \\
\hline Peschel 2007 & No useful outcome data reported. \\
\hline Piestrzeniewicz 2004 & No useful outcome data reported. \\
\hline Pluss 2011 & Comparator received exercise. \\
\hline Poortaghi 2011 & No outcomes of interest. \\
\hline Poortaghi 2013 & Comparator received exercise. \\
\hline Ribeiro 2012 & Follow up only 8 weeks. \\
\hline Rideout 2012 & Intervention does not contain exercise. \\
\hline Roviaro 1984 & Not an RCT. \\
\hline Sadeghi 2013 & Follow up only 8 weeks. \\
\hline Sagar 2012 & Comparator received exercise. \\
\hline Sato 2010 & No outcomes of interest. \\
\hline Sawatzky 2014 & Follow up only 3 months. \\
\hline Schumacher 2006 & No useful outcome data reported. \\
\hline Schwaab 2011 & Not an RCT. \\
\hline Shabani 2010 & Follow up only 12 weeks. \\
\hline
\end{tabular}




\begin{tabular}{|c|c|}
\hline Study & Reason for exclusion \\
\hline Shikhova 2010 & Not an RCT. \\
\hline Siqueira-Catania 2013 & Participants did not have CHD. \\
\hline Soleimannejad 2014 & No outcomes of interest. \\
\hline Stahle 1999 & Follow up only 3 months. \\
\hline Stenlund 2005 & No useful outcome data reported. \\
\hline Takeyama 2000 & No useful outcome data reported. \\
\hline Tokmakidis 2003 & No useful outcome data reported. \\
\hline Turkstra 2013 & Intervention does not contain exercise. \\
\hline Uhlemann 2012 & Comparator received exercise. \\
\hline Walters 2010 & Comparator received exercise. \\
\hline Wood 2008 & No outcomes of interest. \\
\hline Wosornu 1996 & No useful outcome data reported. \\
\hline Yonezawa 2009 & Not an RCT. \\
\hline Zheng 2008 & No useful outcome data reported. \\
\hline Zhu 2013 & Intervention does not include exercise. \\
\hline
\end{tabular}

Characteristics of studies awaiting assessment [ordered by study ID]

Devi 2014

\begin{tabular}{ll}
\hline Methods & RCT \\
\hline
\end{tabular}

Participants

\section{Inclusion criteria:}

- Patients anticipated to be aged from 45 to 70 years, either sex.

- A history of stable angina.

- Undergone coronary angioplasty treatment.

- Fluent in English.

- No prior cardiac rehabilitation in the previous year.

- Regular access to the internet.

\section{Exclusion criteria:}

- Severely anxious or suffering from depression.

- Experiencing unstable angina.

- Significant cardiac arrhythmia.

- Co-morbidities which prevent physical activity.

- Any cardiac rehabilitation treatment in the previous year. 
Devi 2014 (Continued)

Interventions

Intervention: Patients will receive the internet-based CR programme for a period of 6 weeks. The researcher will provide these participants with an introductory session to the web-based programme. These participants will then be expected to follow the online CR programme for a period of 6 weeks.

Comparator: treatment as usual.

\begin{tabular}{ll}
\hline Outcomes & HRQL, costs. \\
\hline Notes & This study is now complete and has been published since the date of the search for this update. \\
\hline
\end{tabular}

Ghroubi 2012

\begin{tabular}{|c|c|}
\hline Methods & $\begin{array}{l}\text { Study design: RCT } \\
\text { Country: NR } \\
\text { Dates patients recruited: NR } \\
\text { Planned follow up: } 2 \text { years }\end{array}$ \\
\hline Participants & $\begin{array}{l}\text { Inclusion criteria: patients with MI who underwent coronary stenting. } \\
\text { Exclusion criteria: NR } \\
\text { N Randomised: total: } 68 \text {; intervention: } 30 \text {; comparator: } 38 \\
\text { Diagnosis (\% of pts): post-coronary stenting after myocardial infraction } \\
\text { Age (years): NR } \\
\text { Percentage male: NR } \\
\text { Ethnicity: NR }\end{array}$ \\
\hline Interventions & Cardiac rehabilitation programme not described. \\
\hline Outcomes & HRQL \\
\hline Notes & $\begin{array}{l}\text { The authors of this conference abstract did not reply to repeated requests for an update on the sta- } \\
\text { tus of this study. }\end{array}$ \\
\hline
\end{tabular}

Son 2008

\begin{tabular}{ll}
\hline Methods & Unclear if randomised study. \\
\hline Participants & Subjects consisted of 58 CAD patients who underwent PCI (experimental group: 30, control group: \\
& $28)$. \\
\hline Interventions & $\begin{array}{l}\text { The experimental group participated in an integrated symptom management programme for } \\
6 \text { months which was composed of tailored education, stress management, exercise, diet, deep } \\
\text { breathing, music therapy, periodical telephone monitoring and a daily log. } \\
\text { The control group received usual care. }\end{array}$ \\
\hline Outcomes & Recurrent cardiac events, self-care activity, quality of life. \\
\hline
\end{tabular}


Son 2008 (Continued)

Notes

Article in Korean. Unable to find translator to answer following questions to determine study inclusion.

- Was this study randomised?

- How do the authors define "recurrent cardiac events"?

- Any other pre-specified outcomes measured reported?

- What scale did the authors use to assess self-care activity and quality of life?

Von Roeder 2011

\begin{tabular}{|c|c|}
\hline Methods & $\begin{array}{l}\text { Study design: } R C T \\
\text { Country: NR } \\
\text { Dates patients recruited: NR } \\
\text { Planned follow up: } 2 \text { years }\end{array}$ \\
\hline Participants & $\begin{array}{l}\text { Inclusion criteria: patients with CAD and proven exercise-induced ischemia. } \\
\text { Exclusion criteria: NR } \\
\text { N Randomised: total: 103; intervention: } 57 \text {; comparator: } 46 \\
\text { Age (years): NR } \\
\text { Percentage male: NR } \\
\text { Ethnicity: NR }\end{array}$ \\
\hline Interventions & $\begin{array}{l}\text { Intervention: regular exercise training. } \\
\text { Comparator: } \mathrm{PCl} / \text { stenting. } \\
\text { Co-interventions: "Both groups received optimized medical treatment." }\end{array}$ \\
\hline Outcomes & Mortality \\
\hline Notes & $\begin{array}{l}\text { The authors of this conference abstract did not reply to repeated requests for an update on the sta- } \\
\text { tus of this study. }\end{array}$ \\
\hline
\end{tabular}

Walther 2010

Methods

Study design: RCT

Country: NR

Dates patients recruited: NR

Planned follow up: 2 years

Participants

Inclusion criteria: Male patients with indication for elective CABG.

Exclusion criteria: NR

N Randomised: total: 47; intervention: 23; comparator: 24

Age (mean \pm SD): $64.3 \pm 7$ years 
Walther 2010 (Continued)

Percentage male: $100 \%$

Ethnicity: NR

Interventions

Intervention: four-week pre-operative endurance training course.

Comparator: non-active control.

Outcomes HRQL and clinical outcomes.

Notes The authors of this conference abstract did not reply to repeated requests for an update on the status of this study.

Characteristics of ongoing studies [ordered by study ID]

Alsaleh 2012

Trial name or title Behavioural intervention to increase physical activity among patients with coronary heart disease: protocol for a randomised controlled trial

\section{Methods}

Study design: Multicentre RCT (2 sites)

Country: Jordan

Dates patients recruited: February 2012 to April 2012

Planned follow up: 6 months

Participants

Inclusion criteria: Clinically stable and able to perform physical activity according to their physician; aged between 18 and 70 years; have access to and ability to use a mobile phone.

Exclusion criteria: Those patients who have co-morbidities or unstable major health problems which prevent them from participating in PA are excluded from the study.

N Randomised: total: 156; intervention: 71; comparator: 85 ically active) delivered over a six month period. This includes a single face-to-face individualised consultation with the researcher, conducted after collecting baseline data at the patients' home or in the hospital clinic, six telephone call consultations (one call each month) supplemented by 18 motivational SMS text messages reminders (comprised of one message each week for the first three months, followed by one message every two weeks for the final three months.

Components: exercise plus psychosocial support.

Setting: home.

\section{Aerobic exercise:}

Modality: intervention is individually tailored.

Length of session: NR

Frequency: NR

Intensity: NR

Resistance training included? NR

Total duration: NR 
Co-interventions: The intervention group will receive advice from their physicians as usual, plus the intervention.

Comparator: The control group will receive their usual standard of care and treatment which includes general advice from their physicians about the benefits of PA and methods of being more active.

Co-interventions: none described.

\begin{tabular}{ll}
\hline Outcomes & HRQL \\
\hline Starting date & February 2012 \\
\hline Contact information & Eman Alsaleh ntxea2@nottingham.ac.uk \\
\hline Notes & The author was contacted and replied that the results would be published shortly. \\
\hline
\end{tabular}

\section{CTRI/2012/02/002408}

Trial name or title

dom

Methods RCT

\section{Participants}

Interventions

Inclusion Criteria: Male and female patients 30 to 80 years old; patients with first or consequent acute MI who survive to hospital discharge.

Interventions

Intervention: Yoga-CaRe is a YOGA-based CR programme delivered at the hospital in 13 sessions spread over 3 months, complemented by audio-video material for self-supervised sessions at home.

Comparator: standard care.

Outcomes Total mortality, nonfatal MI, HRQL at 1 year.

\begin{tabular}{ll}
\hline Starting date & October 2012 \\
\hline Contact information & Dorairaj Prabhakaran \\
& dprabhakaran@ccdcindia.org \\
& http://www.ctri.nic.in/Clinicaltrials/pmaindet2.php?trialid=3992 \\
\hline
\end{tabular}

Notes

\section{IRCT2014061418075N2}

\begin{tabular}{ll}
\hline Trial name or title & The effect of cardiac rehabilitation on quality of life in patients with acute coronary syndrome \\
\hline Methods & RCT \\
\hline Participants & $\begin{array}{l}\text { Inclusion criteria: No history of chronic HF, dementia, disability or contraindications for ex- } \\
\text { ercise; no uncontrolled hypertension, complete Heart Block, uncontrolled dysrhythmia and } \\
\text { thrombophlebitis; any type of heart surgery; allow physicians to participate in rehabilitation pro- } \\
\text { grammes. }\end{array}$
\end{tabular}


IRCT2014061418075N2 (Continued)

Exclusion criteria: Irregular participation in the rehabilitation programme.

Interventions
Comparator: routine care in CCU ward.

\begin{tabular}{ll}
\hline Outcomes & HRQL \\
\hline Starting date & November 2013 \\
\hline Contact information & Asghar khalife zadeh \\
& khalifezadeh@nm.mui.ac.ir \\
\hline
\end{tabular}

Notes

\section{JPRN-UMIN000005177}

\begin{tabular}{|c|c|}
\hline Trial name or title & $\begin{array}{l}\text { Japanese prospective multicenter study on outpatient cardiac rehabilitation after the percuta- } \\
\text { neous coronary intervention }\end{array}$ \\
\hline Methods & $\mathrm{RCT}$ \\
\hline \multirow[t]{2}{*}{ Participants } & $\begin{array}{l}\text { Inclusion criteria: IHD except for AMI received an elective or emergency PCI with a drug-eluting } \\
\text { stent, within } 1 \text { month and have two or more following risk factors, 1) diabetes mellitus or glucose } \\
\text { intolerance, 2) hypertension, 3) hyperlipidemia 4) smoking. }\end{array}$ \\
\hline & $\begin{array}{l}\text { Exclusion criteria: 1) Patients received a PCI after AMI, 2) Patients who experienced cerebrovascu- } \\
\text { lar disease or orthopedic disease which are impediments to the exercise, 3) chronic renal failure, 4) } \\
\text { hepatopathy, 5) other diseases which are impediments to the exercise, 6) CABG within } 3 \text { month, 7) } \\
\text { future plan of } \mathrm{CAGB}, 8 \text { ) patients with difficulty receiving the outpatient rehabilitation. }\end{array}$ \\
\hline Interventions & $\begin{array}{l}\text { Intervention: outpatient CR followed the CR programme. } \\
\text { Comparator: usual care. }\end{array}$ \\
\hline Outcomes & Mortality, IHD, HRQL, reshospitalisation. \\
\hline Starting date & January 2011 \\
\hline \multirow[t]{3}{*}{ Contact information } & Yoichi GOTO \\
\hline & kkatayam@ncvc.go.jp \\
\hline & http://www.umin.ac.jp/ctr/index.htm \\
\hline
\end{tabular}

\section{Notes}

\section{JPRN-UMIN000010031}

\section{Trial name or title}

Methods RC

Impact of comprehensive cardiac rehabilitation program on stabilization of coronary plaque after acute coronary syndrome. 
"1.Acute coronary syndrome patients

2.Patient that coronary artery plaque exists in leaving from area of the body treated by $5 \mathrm{~mm}$ or more and same branches

3.Patient who obtained document agreement by intention of patient himself"

\section{Exclusion criteria:}

"1.Target lesion is bypass graft

2.Cardiogenic shock

3.Acute exacerbation, cirrhosis, and liver carcinoma of acute hepatitis and chronic hepatitis 4.The renal dysfunction (The serum creatinine value is $2.0 \mathrm{mg} / \mathrm{dL}$ or more) or the dialytic treatment is being enforced

5.Patient who judged that examination responsibility doctor is improper as object in present study"

Interventions

Intervention 1: "Patients perform intensive exercise training under supervision by experienced physicians and exercise physiologists one time weekly for $60 \mathrm{~min}$, four times a week for a total 5 months. The training programme is intended to be intensive exercise up to $80 \%$ of the individual exercise capacity and resistance training after 1 month. We recommend for the total number of steps to be 9,000 steps or more per day."

Intervention 2: "Patients perform moderate-intensity exercise training under supervision by experienced physicians and exercise physiologists one time for 2 weeks for $60 \mathrm{~min}$ for a total 5 months.We recommend for the total number of steps to be 6,000 steps or more per day"

Comparator: Patients who drop out and do not participate in comprehensive CR programme.

\begin{tabular}{ll}
\hline Outcomes & Cardiac death, all cause death, MI. \\
\hline Starting date & February 2013 \\
\hline Contact information & Katsumi Miyauchi \\
& ktmmy@juntendo.ac.jp \\
& http://www.umin.ac.jp/ctr/index.htm \\
\hline
\end{tabular}

\begin{tabular}{ll}
\hline Trial name or title & Study of rehabilitation therapy on patients after acute myocardial infarction \\
\hline Methods & RCT \\
\hline Participants & $\begin{array}{l}\text { Inclusion Criteria: Clinical diagnosis of ST-elevated MI, Heart function class I-II. } \\
\text { Exclusion Criteria: History of MI; AMI with severe complications, atrial fibrillation, other severe dis- } \\
\text { eases, such as HIV infection, malignant tumor or chronic diseases of liver, kidney or pulmonary, in- } \\
\text { capable of exercise training. }\end{array}$
\end{tabular}

Comparator: NR

\begin{tabular}{ll}
\hline Outcomes & Cardiac mortality, non-fatal reinfarction, revascularisation (PCI/CABG), hospitalisation. \\
\hline Starting date & December 2006 \\
\hline
\end{tabular}


NCT00725088 (Continued)
Contact information
Wei Gao, MD
dr_gaowei@yahoo.com
http://clinicaltrials.gov/show/NCT00725088

Notes

\section{NCT01916525}

\begin{tabular}{ll}
\hline Trial name or title & Effectiveness of exercise cardiac rehabilitation EFEX-CARE \\
\hline Methods & RCT \\
\hline Participants & $\begin{array}{l}\text { Inclusion Criteria: CAD } \\
\text { Exclusion Criteria: NYHA class IV, HF, angina pectoris at the time of randomisation, severe periph- } \\
\text { eral atherosclerosis (intermittent claudication), severe retinopathy or neuropathy related to dia- } \\
\text { betes. }\end{array}$ \\
\hline Interventions & Intervention: exercise-based CR. \\
\hline Outcomes & Costs, HRQL, major adverse cardiac events. \\
\hline Starting date & February 2011 \\
\hline Contact information & Mikko P Tulppo, PhD \\
mikko.tulppo@verve.fi \\
http://clinicaltrials.gov/show/NCT01916525
\end{tabular}

\section{Notes}

\section{NCT01941355}

\begin{tabular}{ll}
\hline Trial name or title & Trial of rehabilitation in phase 1 after coronary artery bypass grafting SheppHeart \\
\hline Methods & RCT \\
\hline Participants & $\begin{array}{l}\text { Inclusion Criteria: } 18 \text { years or older, IHD referred for elective CABG, speaks and understands Dan- } \\
\text { ish. } \\
\text { Exclusion Criteria: intermediate or high risk according to their cardiovascular status, patients with } \\
\text { illness limiting the ability to exercise, patients without permanent residence. }\end{array}$ \\
\hline Interventions & Intervention: exercise training component and psycho-educative component. \\
\hline Cutcomes & Comparator: NR \\
\hline Starting date & September 2013 \\
\hline Contact information & Selina K Berg, RN, PhD \\
\hline
\end{tabular}


NCT01941355 (Continued)

Notes

NCT02025257

Trial name or title

\begin{tabular}{ll}
\hline Methods & RCT
\end{tabular}

RCT
Effects of exercise in patients with coronary artery disease aged 80 years or older

Inclusion Criteria: Clinical diagnosis of acute CAD, aged 80 years or older.

Exclusion Criteria: Inability to understand or speak Swedish, serious physical or psychological disease interfering with participation in an exercise intervention, patients are already exercising three times or more/week.

Intervention: exercise

Comparator: NR

\begin{tabular}{ll}
\hline Outcomes & HRQL \\
\hline Starting date & December 2013 \\
\hline Contact information & Maria Bäck, PhD \\
& maria.m.back@vgregion.se \\
& http://clinicaltrials.gov/show/NCT02025257
\end{tabular}

Notes

\section{NCT02219815}

Trial name or title

Pre-operative rehabilitation for reduction of hospitalization after coronary bypass and valvular surgery (PREHAB)

Methods RCT

Participants

\section{Inclusion Criteria:}

- Patients aged 65 years and older, undergoing elective isolated CABG, aortic valve repair/replacement for moderate aortic stenosis or severe regurgitation, mitral valve repair/replacement for moderate stenosis or severe regurgitation or combined CABG/valve procedures.

- Patients with Clinical Frailty Score (CFS) $\geq 4$ (vulnerable) and $<7$ ( $8=$ very severely frail, approaching end-of-life or $9=$ terminally ill) at time of acceptance for cardiac surgery.

- Patients with an estimated $\geq 6$ week wait time.

\section{Exclusion Criteria:}

- Patients who have unstable or recent unstable cardiac syndrome as defined by: severe heart failure (NYHA IV) or angina (CCS class IV) symptoms; critical left main (LM) coronary disease; hospitalisation for arrhythmias, congestive heart failure or acute coronary syndrome prior to randomisation. 
NCT02219815 (Continued)

- Patients who have severe left ventricular obstructive disease as defined by: severe aortic or mitral stenosis (aortic or mitral valve area $<1.0 \mathrm{~cm}^{2}$ or mean gradient $>40 \mathrm{mmHg}$ or $>10 \mathrm{mmHg}$ respectively); dynamic left ventricular (LV) outflow obstruction.

- Patients who have demonstrated exercise-induced ventricular arrhythmias or have experienced a recent hospitalisation for arrhythmias.

- Patients who have cognitive deficits that would preclude rehabilitation.

- Patients who have physical limitations that would preclude rehabilitation.

- Patients who are unable to attend the Prehab programme.
Intervention: Patients will receive an eight-week comprehensive exercise therapy and education programme at a community-based CR facility.

Comparator: standard care.

\begin{tabular}{ll}
\hline Outcomes & Mortality, major adverse cardiac events, HRQL. \\
\hline Starting date & September 2014 \\
\hline Contact information & Dr. Rakesh C. Arora \\
& rarora@sbgh.mb.ca \\
\hline
\end{tabular}

Notes

NCT02235753

\begin{tabular}{ll}
\hline Trial name or title & High-intensity exercise after acute cardiac event (HITCARE) \\
\hline Methods & RCT \\
\hline Participants & $\begin{array}{l}\text { Inclusion Criteria: hospital care after acute CAD event, age 40-80 years. } \\
\text { Exclusion Criteria: conditions preventing regular exercise training, severe/malignant disease (life } \\
\text { expectancy }<12 \text { months). }\end{array}$
\end{tabular}

Interventions
Comparator: NR

\begin{tabular}{ll}
\hline Outcomes & HRQL, costs. \\
\hline Starting date & December 2014 \\
\hline Contact information & Rainer Rauramaa, professor, MD \\
& rainer.rauramaa@uef.fi \\
& http://clinicaltrials.gov/show/NCT02235753 \\
\hline Notes & It is not clear if there is a comparator which does not include exercise. \\
\hline
\end{tabular}




\section{Methods}

\section{Study design: Single centre RCT}

Country: Spain

Dates patients recruited: not stated

Maximum follow up: 1 year
Participants

\section{Inclusion criteria:}

- age over 18;

- diagnosis of MI (myocardial ischemia, pre-infarct angina, cardiac angina, other specific forms of chronic ischemic heart disease or unspecified ischemic heart disease) in the current admission;

- residence in the catchment area of our hospital;

- absence of cognitive deficit (Pfeiffer test: 0-2 mistakes);

- sufficient autonomy to follow the cardiac rehabilitation programme (Barthel index $>60$ );

- willingness to participate in the study.

\section{Exclusion criteria:}

Patients will be excluded if:

- they have symptoms of right heart failure producing pulmonary hypertension or dyspnea caused by severe pulmonary pathology;

- additional comorbidities affecting the prognosis of cardiac disease;

- major comorbidities or limitations that could interfere with exercise training programme;

- cognitive impairment; or

- if they do not provide informed consent.
Intervention: In addition to the usual hospital care, patients randomised to the intervention group will be provided with a supervised outpatient exercise training programme, according to the results of the exercise stress test performed one month after hospital discharge and bearing in mind the physical limitations imposed by co-morbid conditions. The programme will be performed in the hospital and it will start within the three days after the exercise stress test. It will comprise three hours a week (spread over three alternate days) of supervised exercise training for 10 weeks. The intervention will end after 10 weeks, regardless of whether the patients have completed 30 sessions. Exercise classes will be supervised by a physiotherapist and will consist of 10 minutes of warm-up and muscle stretching, 30 minutes of aerobic exercises (cycloergometer), 15 minutes of isotonic exercises for the upper and lower extremities and 5 minutes of cool-down. Moreover, instructions will be given on self-pulse counting, subjective perception of effort using the Borg scale, relaxation exercises, breathing techniques, postural health and minimising physical effort. Aerobic exercise intensity will be between $75-90 \%$ of the maximum heart rate obtained in the previous exercise stress test and progressing according to the rating of perceived exertion (RPE: Borg scale 11$15)$.

Resistance training will be performed with 10-15 repetitions for three sets, maintaining an RPE of 11-14. The physiotherapist will check that patients are exercising at their prescribed intensity with a pulse oximeter (Quirumed ${ }^{\circledR}$ Health \& Care).

Components: exercise only.

Setting: supervised group sessions at the hospital.

\section{Aerobic exercise:}

Modality: cycloergometer.

Length of session: 1 hour. 
Frequency: 3 sessions per week.

Intensity: $75-90 \%$ of the maximum heart rate (RPE: Borg scale $11-15)$.

Resistance training included? Yes.

Total duration: 10 weeks.

Co-interventions: After hospital discharge, patients in both groups will have scheduled follow-up visits with a cardiac nurse at the first month, and then after 3, 6 and 12 months (visits 1, 2, 3 and 4 respectively) since hospital discharge in order to control the risk factors, reinforce education for disease control and review adherence to cardiac medication and CRP follow-up.

Comparator: The control group will receive the standard care given at the hospital.

Co-interventions: Patients will receive verbal and written information on cardiovascular risk factors from the cardiac nurse or the physiotherapist. Hospitalised patients will be instructed to do exercises to regain mobility in order to maintain and improve muscular tone and peripheral circulation, and will be taught breathing exercises by the physiotherapist to improve their breathing patterns. Before discharge, the physiotherapist will instruct patients on how to return to physical activity.

After hospital discharge, patients in both groups will have scheduled follow-up visits with a cardiac nurse at the first month, and then after 3, 6 and 12 months (visits 1, 2, 3 and 4 respectively) since hospital discharge in order to control the risk factors, reinforce education for disease control and review adherence to cardiac medication and CRP follow-up.

\begin{tabular}{ll}
\hline Outcomes & Mortality, MI, hospitalisations, HRQL. \\
\hline Starting date & Not stated. \\
\hline Contact information & Núria Santaularia; nsantaul@althaia.cat \\
\hline Notes & The author was contacted and replied that the results would be published shortly. \\
\hline
\end{tabular}

DATA AND ANALYSES

Comparison 1. Exercise-based rehabilitation versus usual care

\begin{tabular}{llllll}
\hline Outcome or subgroup title & $\begin{array}{l}\text { No. of } \\
\text { studies }\end{array}$ & $\begin{array}{l}\text { No. of } \\
\text { partici- } \\
\text { pants }\end{array}$ & Statistical method & Effect size \\
\hline 1 Total mortality & 47 & & $\begin{array}{l}\text { Risk Ratio (M-H, Random, 95\% } \\
\text { Cl) }\end{array}$ & Subtotals only \\
\hline 1.1 Follow-up of 6 to 12 months & 29 & 8800 & $\begin{array}{l}\text { Risk Ratio (M-H, Random, 95\% } \\
\text { Cl) }\end{array}$ & $0.88[0.73,1.05]$ \\
\hline 1.2 Follow-up of $>12$ to 36 months & 13 & 6823 & $\begin{array}{l}\text { Risk Ratio (M-H, Random, 95\% } \\
\text { Cl) }\end{array}$ & $0.89[0.78,1.01]$ \\
\hline 1.3 Follow-up longer than 3 years & 11 & 3828 & $\begin{array}{l}\text { Risk Ratio (M-H, Random, 95\% } \\
\text { Cl) }\end{array}$ & $0.91[0.75,1.10]$ \\
\hline
\end{tabular}




\begin{tabular}{|c|c|c|c|c|}
\hline Outcome or subgroup title & $\begin{array}{l}\text { No. of } \\
\text { studies }\end{array}$ & $\begin{array}{l}\text { No. of } \\
\text { partici- } \\
\text { pants }\end{array}$ & Statistical method & Effect size \\
\hline 2 Cardiovascular mortality & 27 & & $\begin{array}{l}\text { Risk Ratio (M-H, Random, 95\% } \\
\mathrm{Cl})\end{array}$ & Subtotals only \\
\hline 2.1 Follow-up of 6 to 12 months & 15 & 4884 & $\begin{array}{l}\text { Risk Ratio (M-H, Random, 95\% } \\
\mathrm{Cl})\end{array}$ & $0.90[0.69,1.17]$ \\
\hline 2.2 Follow-up of $>12$ months to 36 months & 7 & 3833 & $\begin{array}{l}\text { Risk Ratio (M-H, Random, 95\% } \\
\text { Cl) }\end{array}$ & $0.77[0.63,0.93]$ \\
\hline 2.3 Follow-up of longer than 3 years & 8 & 1392 & $\begin{array}{l}\text { Risk Ratio (M-H, Random, 95\% } \\
\text { Cl) }\end{array}$ & $0.58[0.43,0.78]$ \\
\hline 3 Fatal and/or nonfatal MI & 36 & & $\begin{array}{l}\text { Risk Ratio (M-H, Random, 95\% } \\
\mathrm{Cl} \text { ) }\end{array}$ & Subtotals only \\
\hline 3.1 Follow-up of 6 to 12 months & 20 & 6911 & $\begin{array}{l}\text { Risk Ratio (M-H, Random, 95\% } \\
\text { Cl) }\end{array}$ & $0.85[0.67,1.08]$ \\
\hline 3.2 Follow-up of $>12$ to 36 months & 11 & 5644 & $\begin{array}{l}\text { Risk Ratio (M-H, Random, 95\% } \\
\text { Cl) }\end{array}$ & $1.09[0.91,1.29]$ \\
\hline 3.3 Follow-up of longer than 3 years & 10 & 1560 & $\begin{array}{l}\text { Risk Ratio (M-H, Random, 95\% } \\
\text { Cl) }\end{array}$ & $0.67[0.50,0.90]$ \\
\hline 4 CABG & 29 & & $\begin{array}{l}\text { Risk Ratio (M-H, Random, 95\% } \\
\mathrm{Cl})\end{array}$ & Subtotals only \\
\hline 4.1 Follow-up of 6 to 12 months & 21 & 4563 & $\begin{array}{l}\text { Risk Ratio (M-H, Random, 95\% } \\
\mathrm{Cl} \text { ) }\end{array}$ & $0.99[0.77,1.26]$ \\
\hline 4.2 Follow-up of $>12$ to 36 months & 8 & 2755 & $\begin{array}{l}\text { Risk Ratio (M-H, Random, 95\% } \\
\mathrm{Cl} \text { ) }\end{array}$ & $0.98[0.78,1.25]$ \\
\hline 4.3 Follow-up of longer than 3 years & 4 & 675 & $\begin{array}{l}\text { Risk Ratio (M-H, Random, 95\% } \\
\mathrm{Cl})\end{array}$ & $0.66[0.34,1.27]$ \\
\hline $5 \mathrm{PCl}$ & 18 & & $\begin{array}{l}\text { Risk Ratio (M-H, Random, 95\% } \\
\mathrm{Cl} \text { ) }\end{array}$ & Subtotals only \\
\hline 5.1 Follow-up of 6 to 12 months & 13 & 3564 & $\begin{array}{l}\text { Risk Ratio (M-H, Random, 95\% } \\
\mathrm{Cl} \text { ) }\end{array}$ & $0.92[0.64,1.33]$ \\
\hline 5.2 Follow-up of $>12$ to 36 months & 6 & 1983 & $\begin{array}{l}\text { Risk Ratio (M-H, Random, 95\% } \\
\text { Cl) }\end{array}$ & $0.96[0.69,1.35]$ \\
\hline 5.3 Follow-up of longer than 3 years & 3 & 567 & $\begin{array}{l}\text { Risk Ratio (M-H, Random, 95\% } \\
\text { Cl) }\end{array}$ & $0.76[0.48,1.20]$ \\
\hline 6 Hospital admissions & 15 & & $\begin{array}{l}\text { Risk Ratio (M-H, Random, 95\% } \\
\mathrm{Cl} \text { ) }\end{array}$ & Subtotals only \\
\hline 6.1 Follow-up of 6 to 12 months & 9 & 1120 & $\begin{array}{l}\text { Risk Ratio (M-H, Random, 95\% } \\
\mathrm{Cl})\end{array}$ & $0.65[0.46,0.92]$ \\
\hline
\end{tabular}




\begin{tabular}{lllll}
\hline Outcome or subgroup title & $\begin{array}{l}\text { No. of } \\
\text { studies }\end{array}$ & $\begin{array}{l}\text { No. of } \\
\text { partici- } \\
\text { pants }\end{array}$ & Statistical method & Effect size \\
\hline 6.2 Follow-up of > 12 to 36 months & 6 & 1916 & $\begin{array}{l}\text { Risk Ratio (M-H, Random, 95\% } \\
\mathrm{Cl})\end{array}$ & $0.95[0.84,1.07]$ \\
\hline 6.3 Follow-up of longer than 3 years & 0 & 0 & $\begin{array}{l}\text { Risk Ratio (M-H, Random, 95\% } \\
\mathrm{Cl})\end{array}$ & $0.0[0.0,0.0]$ \\
\hline
\end{tabular}

Analysis 1.1. Comparison 1 Exercise-based rehabilitation versus usual care, Outcome 1 Total mortality.

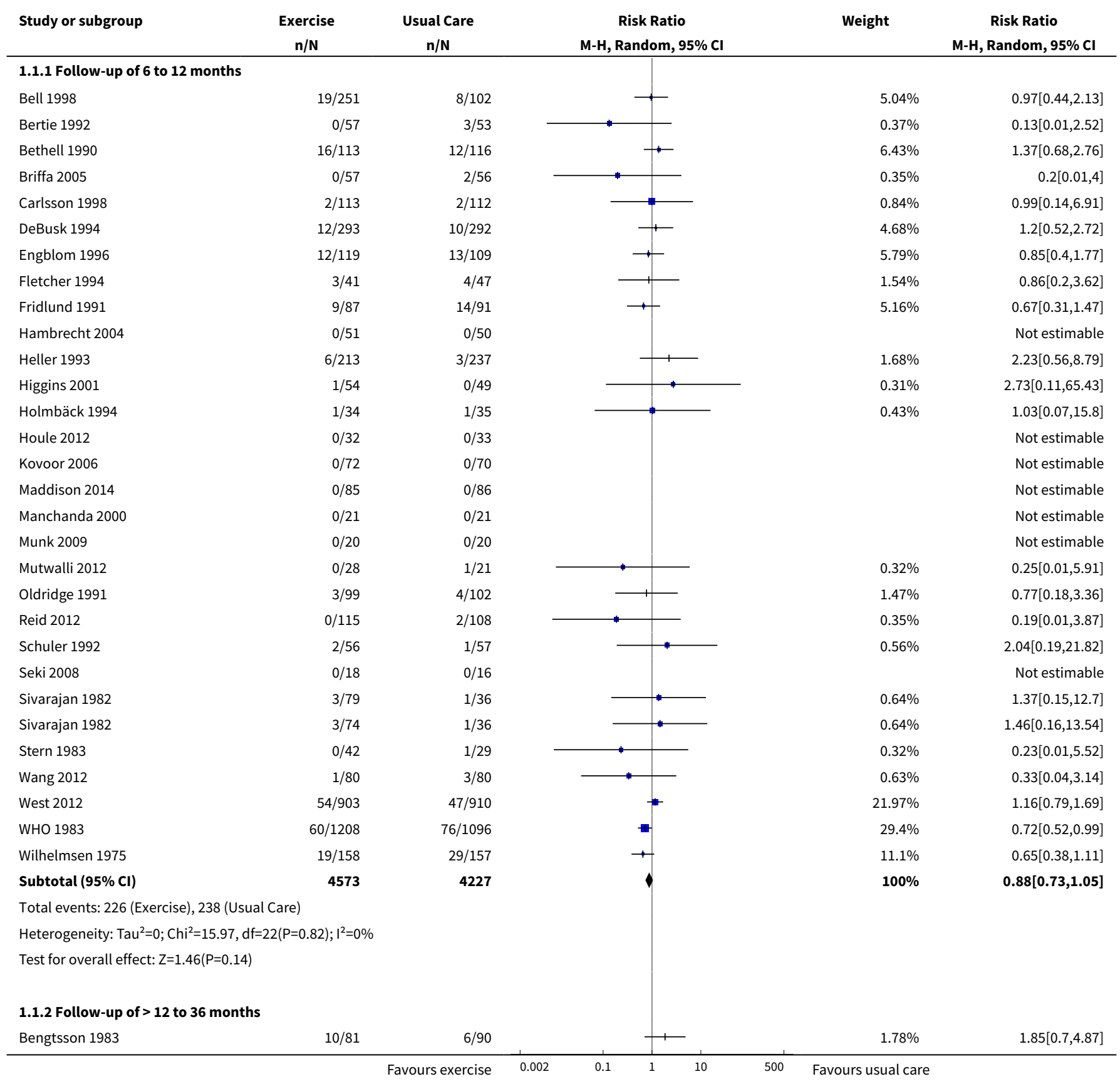




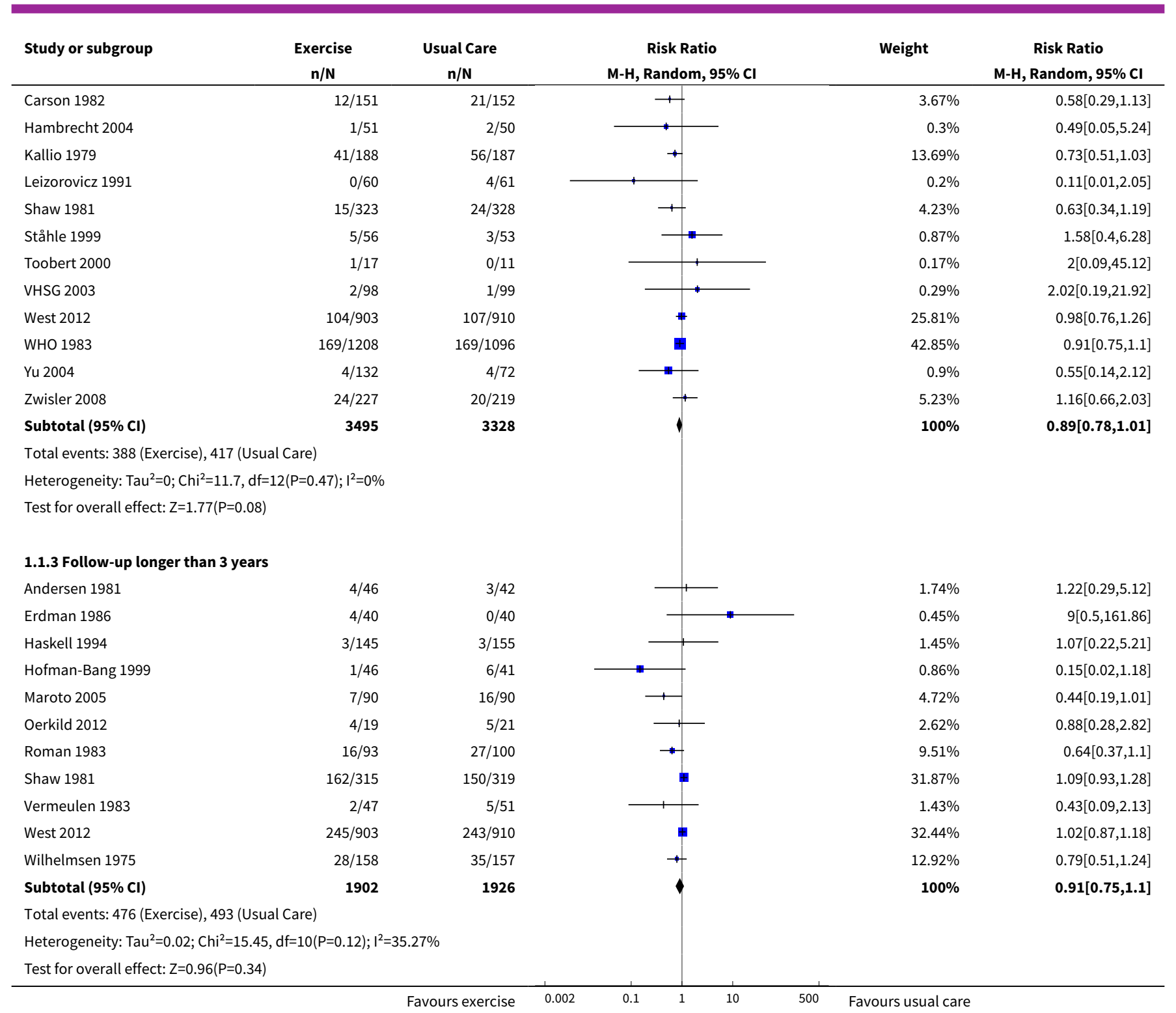

Analysis 1.2. Comparison 1 Exercise-based rehabilitation versus usual care, Outcome 2 Cardiovascular mortality.

\begin{tabular}{|c|c|c|c|c|c|}
\hline Study or subgroup & $\begin{array}{c}\text { Exercise } \\
\mathbf{n} / \mathbf{N}\end{array}$ & $\begin{array}{c}\text { Usual Care } \\
\mathrm{n} / \mathrm{N} \\
\end{array}$ & $\begin{array}{c}\text { Risk Ratio } \\
\text { M-H, Random, } 95 \% \mathrm{Cl}\end{array}$ & Weight & $\begin{array}{c}\text { Risk Ratio } \\
\text { M-H, Random, } 95 \% \text { CI }\end{array}$ \\
\hline \multicolumn{6}{|c|}{ 1.2.1 Follow-up of 6 to 12 months } \\
\hline Aronov 2010 & $3 / 197$ & $6 / 195$ & + & $3.7 \%$ & $0.49[0.13,1.95]$ \\
\hline Bethell 1990 & $13 / 113$ & $12 / 116$ & $\rightarrow$ & $12.68 \%$ & $1.11[0.53,2.33]$ \\
\hline Briffa 2005 & $0 / 57$ & $1 / 56$ & - & $0.69 \%$ & $0.33[0.01,7.87]$ \\
\hline DeBusk 1994 & $11 / 293$ & $9 / 292$ & $\rightarrow$ & $9.28 \%$ & $1.22[0.51,2.9]$ \\
\hline Haskell 1994 & $1 / 145$ & $0 / 155$ & . & $0.68 \%$ & $3.21[0.13,78.06]$ \\
\hline Maddison 2014 & $0 / 85$ & $0 / 86$ & & & Not estimable \\
\hline Miller 1984 & $0 / 127$ & $2 / 71$ & - & $0.76 \%$ & $0.11[0.01,2.31]$ \\
\hline Munk 2009 & $0 / 20$ & $0 / 20$ & & & Not estimable \\
\hline
\end{tabular}




\begin{tabular}{|c|c|c|c|c|c|}
\hline Study or subgroup & $\begin{array}{c}\text { Exercise } \\
\mathbf{n} / \mathbf{N}\end{array}$ & $\begin{array}{c}\text { Usual Care } \\
\mathbf{n} / \mathbf{N} \\
\end{array}$ & $\begin{array}{c}\text { Risk Ratio } \\
\text { M-H, Random, } 95 \% \mathrm{CI}\end{array}$ & Weight & $\begin{array}{c}\text { Risk Ratio } \\
\text { M-H, Random, } 95 \% \text { CI }\end{array}$ \\
\hline Ornish 1990 & $2 / 28$ & $1 / 20$ & + & $1.28 \%$ & $1.43[0.14,14.7]$ \\
\hline Schuler 1992 & $2 / 56$ & $0 / 57$ & 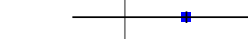 & $0.77 \%$ & $5.09[0.25,103.66]$ \\
\hline Seki 2008 & $0 / 20$ & $0 / 19$ & & & Not estimable \\
\hline Sivarajan 1982 & $3 / 71$ & $1 / 32$ & & $1.41 \%$ & $1.35[0.15,12.5]$ \\
\hline Sivarajan 1982 & $3 / 65$ & $0 / 33$ & $\rightarrow$ & $0.81 \%$ & $3.61[0.19,67.81]$ \\
\hline Vecchio 1981 & $0 / 25$ & $2 / 25$ & & $0.78 \%$ & $0.2[0.01,3.97]$ \\
\hline WHO 1983 & $67 / 1208$ & $71 / 1096$ & & $66.4 \%$ & $0.86[0.62,1.18]$ \\
\hline Subtotal $(95 \% \mathrm{CI})$ & 2561 & 2323 & & $100 \%$ & $0.9[0.69,1.17]$ \\
\hline \multicolumn{6}{|c|}{ Total events: 105 (Exercise), 107 (Usual Care) } \\
\hline \multicolumn{6}{|c|}{ Heterogeneity: $\operatorname{Tau}^{2}=0 ; \mathrm{Chi}^{2}=8.79, \mathrm{df}=12(\mathrm{P}=0.72) ; \mathrm{I}^{2}=0 \%$} \\
\hline \multicolumn{6}{|c|}{ Test for overall effect: $\mathrm{Z}=0.8(\mathrm{P}=0.43)$} \\
\hline \multicolumn{6}{|c|}{ 1.2.2 Follow-up of $>12$ months to 36 months } \\
\hline Belardinelli 2001 & $0 / 59$ & $0 / 59$ & & & Not estimable \\
\hline Hambrecht 2004 & $0 / 51$ & $0 / 50$ & & & Not estimable \\
\hline Kallio 1979 & $35 / 188$ & $55 / 187$ & - & $24.48 \%$ & $0.63[0.44,0.92]$ \\
\hline Shaw 1981 & $14 / 323$ & $20 / 328$ & $\rightarrow$ & $8.15 \%$ & $0.71[0.37,1.38]$ \\
\hline Specchia 1996 & $5 / 125$ & $13 / 131$ & 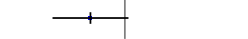 & $3.66 \%$ & $0.4[0.15,1.1]$ \\
\hline Toobert 2000 & $1 / 17$ & $0 / 11$ & - & $0.38 \%$ & $2[0.09,45.12]$ \\
\hline WHO 1983 & $144 / 1208$ & $151 / 1096$ & $e^{2}$ & $63.33 \%$ & $0.87[0.7,1.07]$ \\
\hline Subtotal $(95 \% \mathrm{Cl})$ & 1971 & 1862 & $\checkmark$ & $100 \%$ & $0.77[0.63,0.93]$ \\
\hline \multicolumn{6}{|c|}{ Total events: 199 (Exercise), 239 (Usual Care) } \\
\hline \multicolumn{6}{|c|}{ Heterogeneity: $\mathrm{Tau}^{2}=0 ; \mathrm{Chi}^{2}=4.21, \mathrm{df}=4(\mathrm{P}=0.38) ; \mathrm{I}^{2}=5.02 \%$} \\
\hline \multicolumn{6}{|c|}{ Test for overall effect: $Z=2.66(P=0.01)$} \\
\hline \multicolumn{6}{|c|}{ 1.2.3 Follow-up of longer than 3 years } \\
\hline Dugmore 1999 & $2 / 62$ & $3 / 62$ & & $3.01 \%$ & $0.67[0.12,3.85]$ \\
\hline Haskell 1994 & $2 / 145$ & $3 / 155$ & 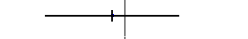 & $2.94 \%$ & $0.71[0.12,4.2]$ \\
\hline Hofman-Bang 1999 & $1 / 46$ & $6 / 41$ & & $2.15 \%$ & $0.15[0.02,1.18]$ \\
\hline La Rovere 2002 & $6 / 49$ & $12 / 46$ & $\longrightarrow$ & $11.6 \%$ & $0.47[0.19,1.15]$ \\
\hline Maroto 2005 & $7 / 90$ & $14 / 90$ & $\rightarrow$ & $12.55 \%$ & $0.5[0.21,1.18]$ \\
\hline Roman 1983 & $13 / 93$ & $24 / 100$ & $*$ & $24.64 \%$ & $0.58[0.32,1.08]$ \\
\hline Vermeulen 1983 & $2 / 47$ & $5 / 51$ & $\begin{array}{l}\square-1 \\
\end{array}$ & $3.66 \%$ & $0.43[0.09,2.13]$ \\
\hline Wilhelmsen 1975 & $23 / 158$ & $33 / 157$ & + & $39.46 \%$ & $0.69[0.43,1.12]$ \\
\hline Subtotal $(95 \% \mathrm{Cl})$ & 690 & 702 & $\diamond$ & $100 \%$ & $0.58[0.43,0.78]$ \\
\hline \multicolumn{6}{|c|}{ Total events: 56 (Exercise), 100 (Usual Care) } \\
\hline \multicolumn{6}{|c|}{ Heterogeneity: $\mathrm{Tau}^{2}=0 ; \mathrm{Chi}^{2}=2.73, \mathrm{df}=7(\mathrm{P}=0.91) ;\left.\right|^{2}=0 \%$} \\
\hline Test for overall effect & & & & & \\
\hline
\end{tabular}

Analysis 1.3. Comparison 1 Exercise-based rehabilitation versus usual care, Outcome 3 Fatal and/or nonfatal MI.

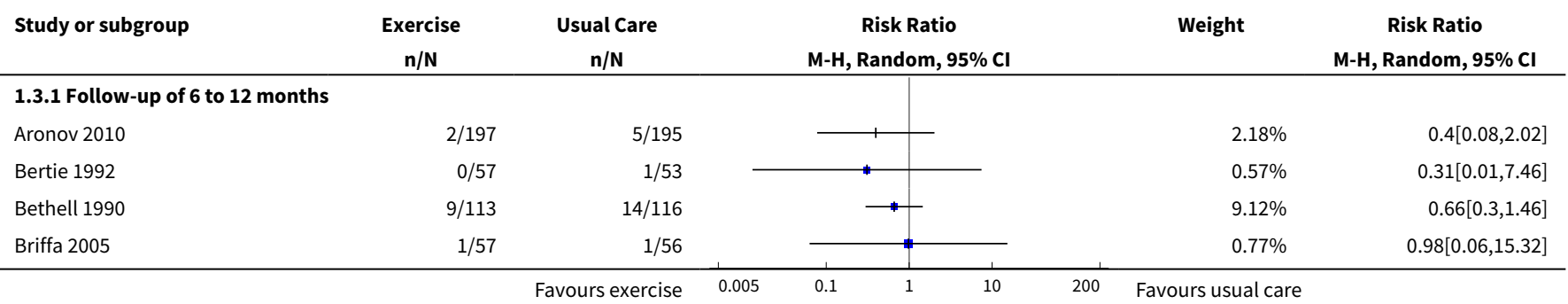




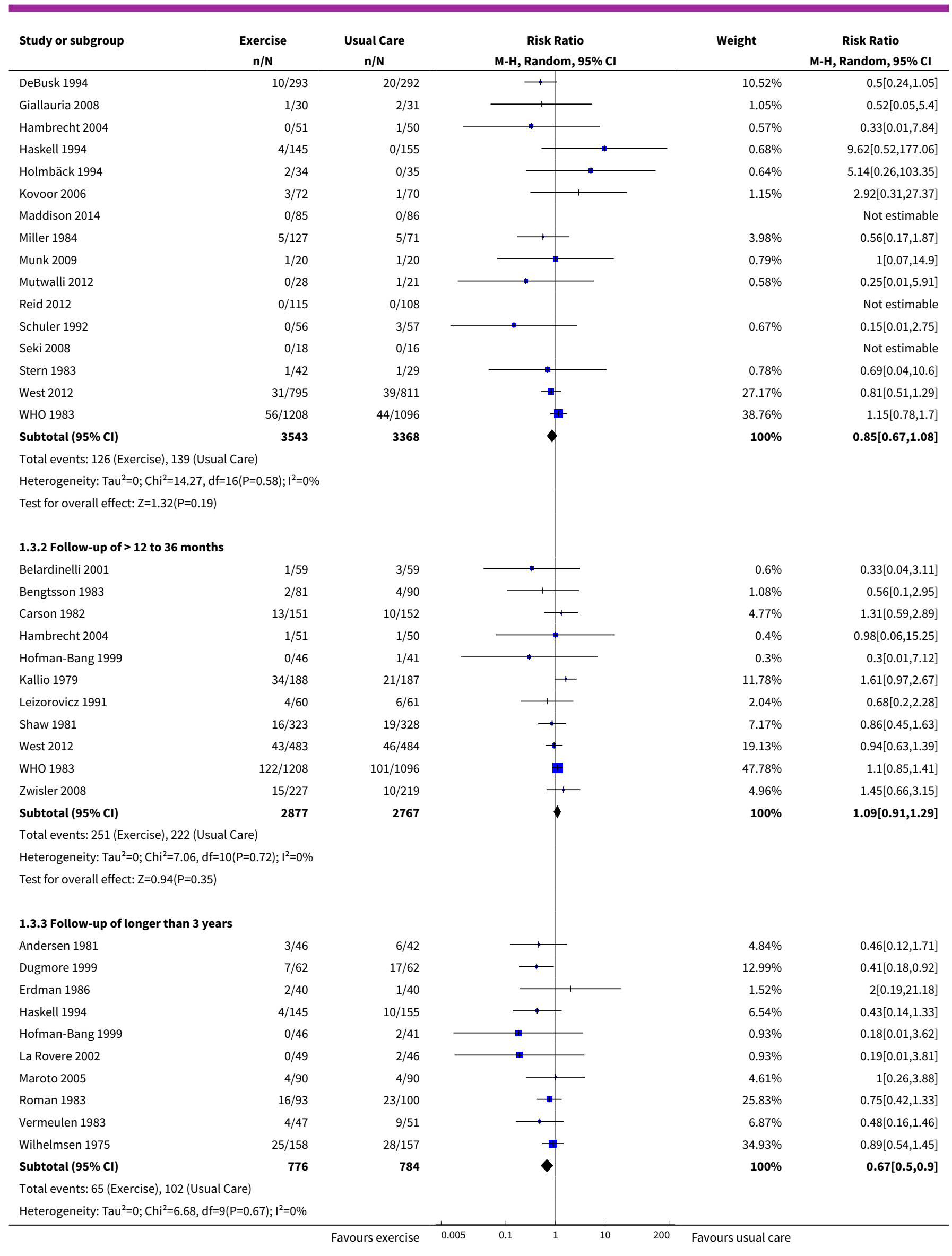




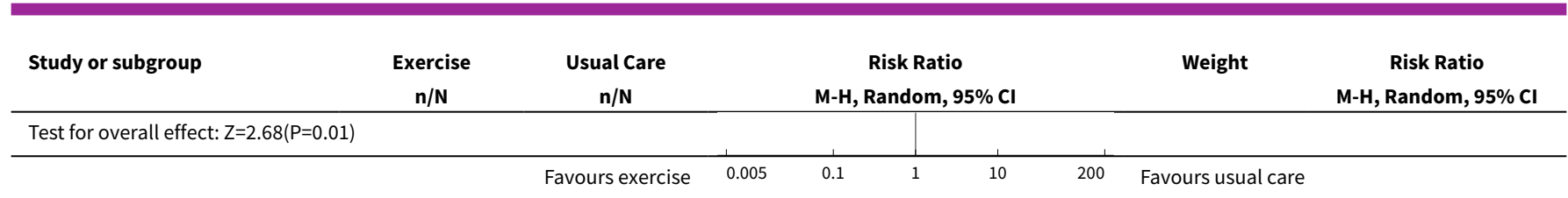

Analysis 1.4. Comparison 1 Exercise-based rehabilitation versus usual care, Outcome 4 CABG.

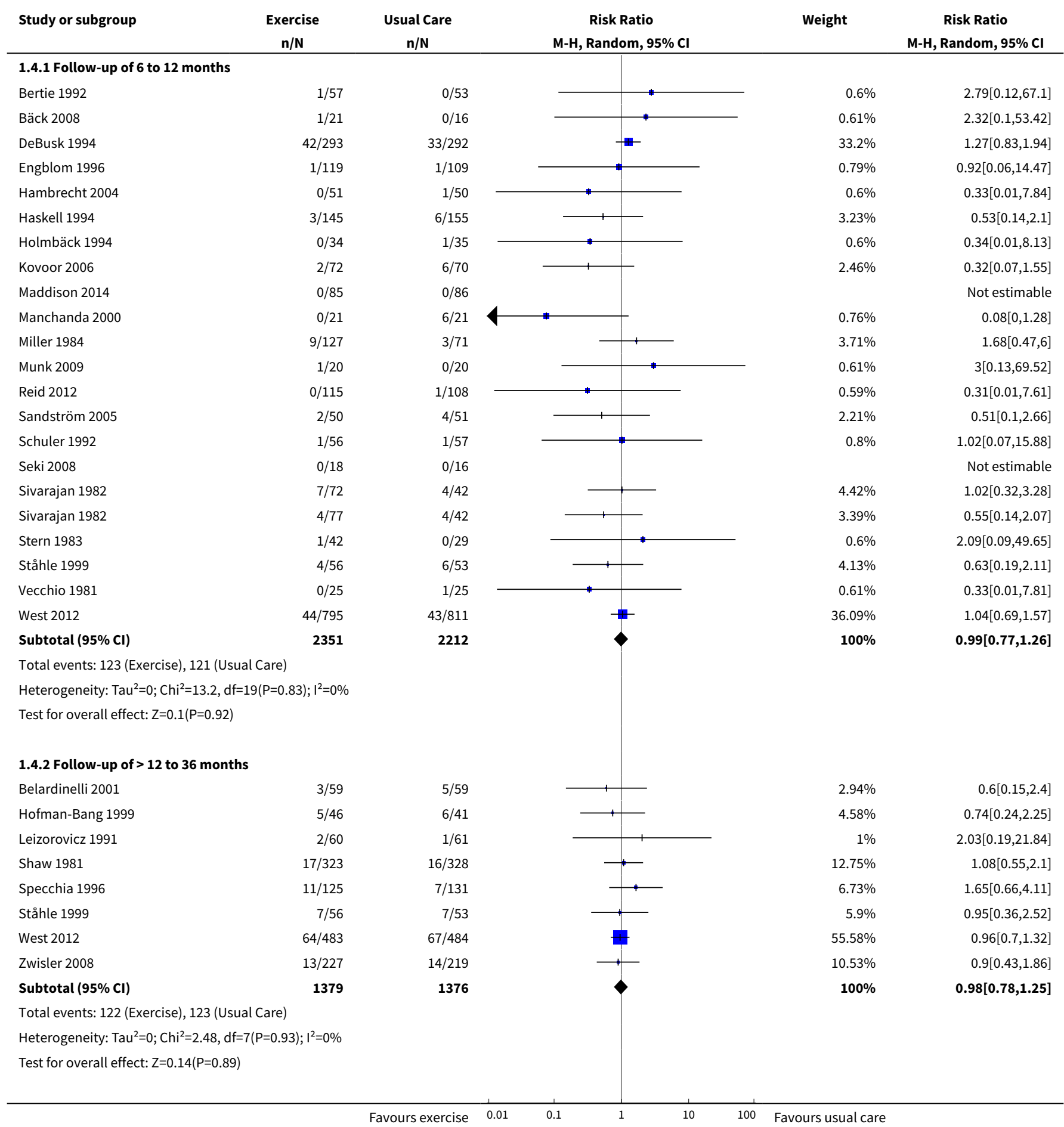




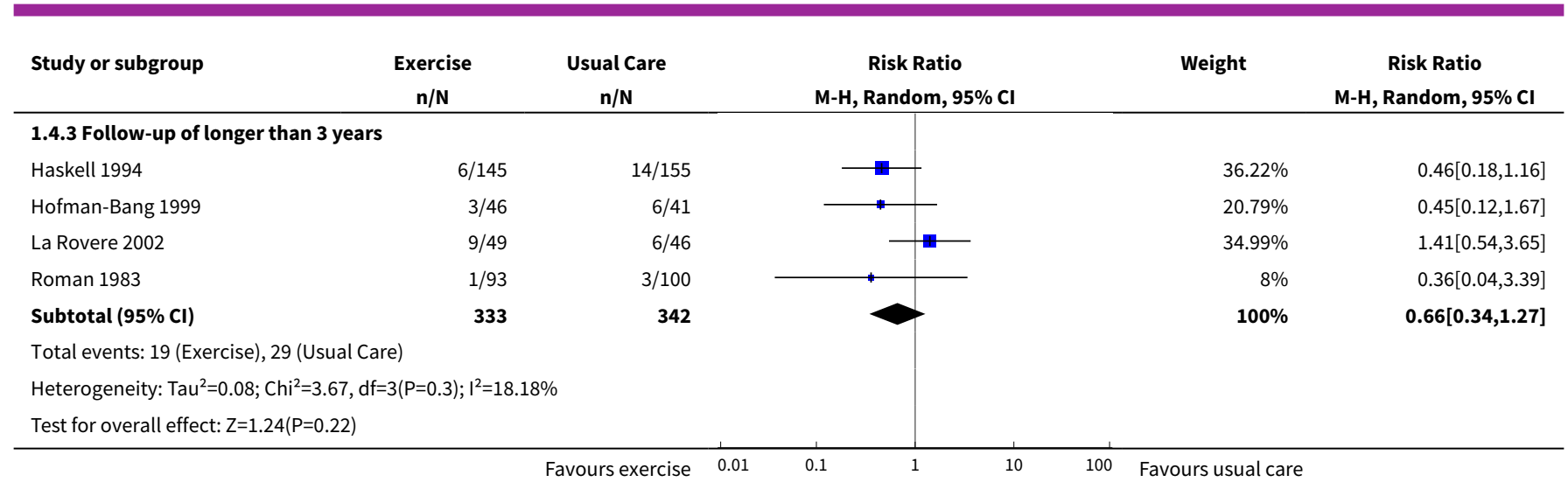

Analysis 1.5. Comparison 1 Exercise-based rehabilitation versus usual care, Outcome 5 PCI.

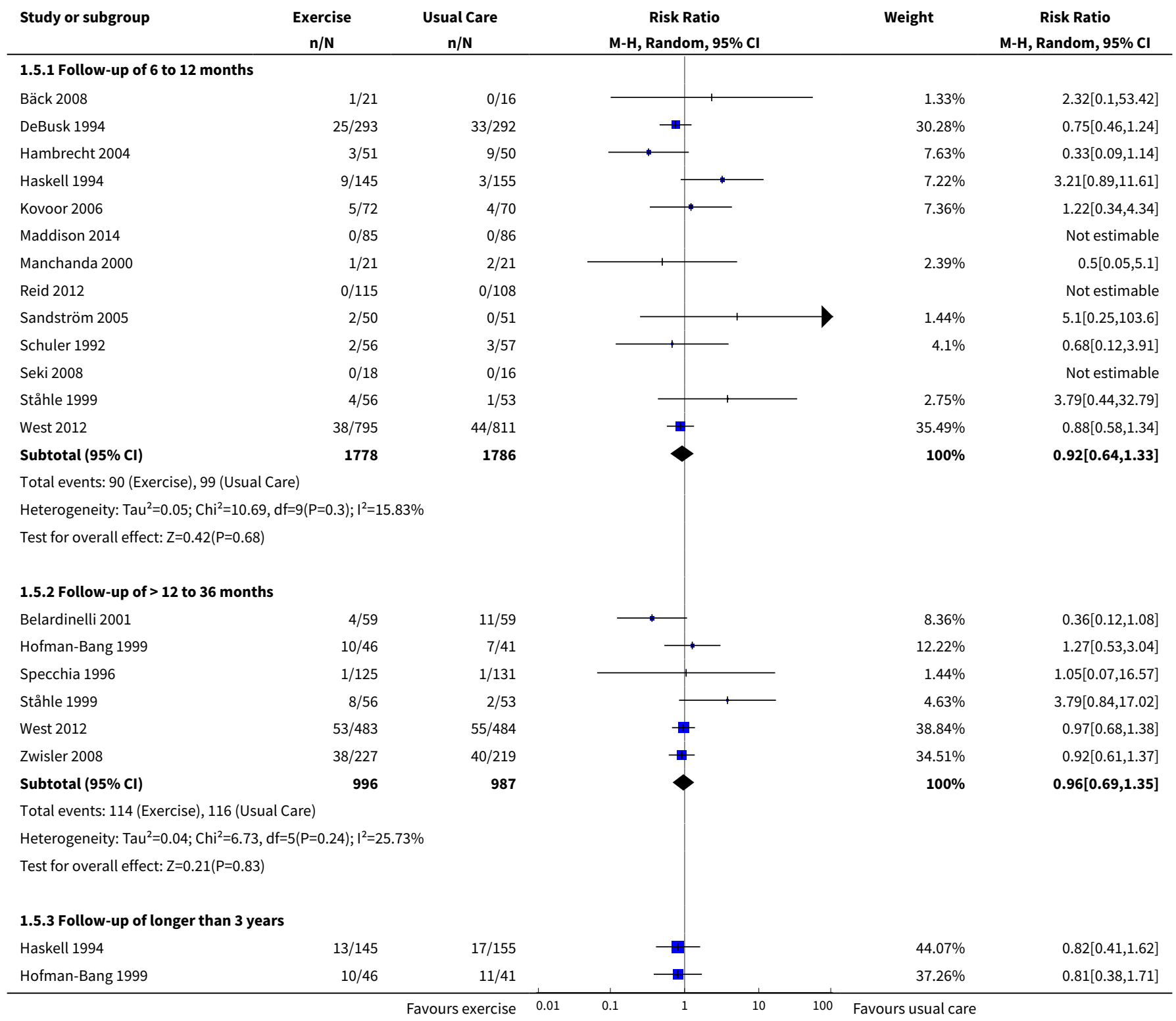




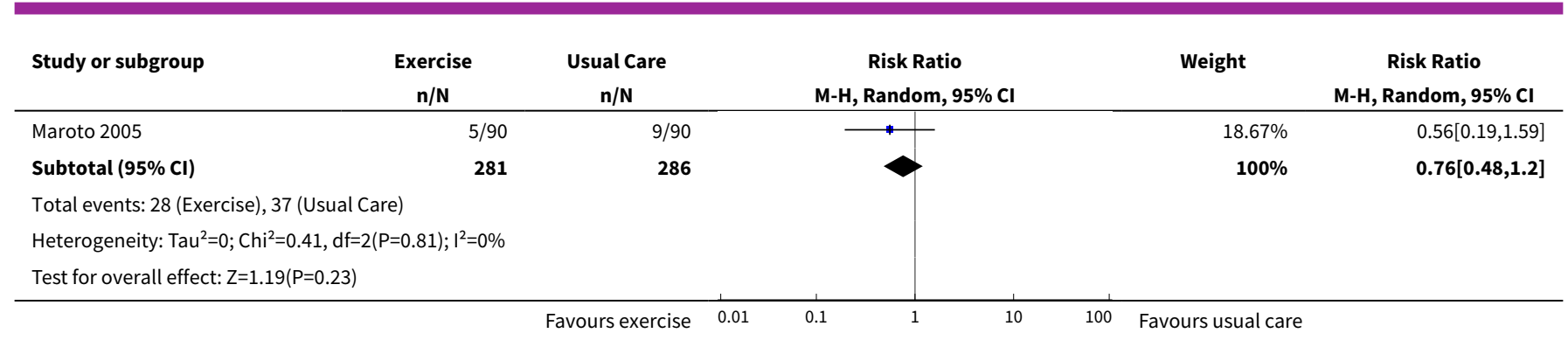

Analysis 1.6. Comparison 1 Exercise-based rehabilitation versus usual care, Outcome 6 Hospital admissions.

\begin{tabular}{|c|c|c|c|c|c|}
\hline Study or subgroup & $\begin{array}{c}\text { Exercise } \\
n / N\end{array}$ & $\begin{array}{l}\text { Usual Care } \\
\mathbf{n} / \mathbf{N}\end{array}$ & $\begin{array}{c}\text { Risk Ratio } \\
\text { M-H, Random, } 95 \% \text { Cl }\end{array}$ & Weight & $\begin{array}{c}\text { Risk Ratio } \\
\text { M-H, Random, } 95 \% \mathrm{Cl}\end{array}$ \\
\hline \multicolumn{6}{|c|}{ 1.6.1 Follow-up of 6 to 12 months } \\
\hline Briffa 2005 & $19 / 57$ & $19 / 56$ & $\rightarrow$ & $20.17 \%$ & $0.98[0.59,1.65]$ \\
\hline Engblom 1996 & $26 / 102$ & $34 / 91$ & & $23.76 \%$ & $0.68[0.45,1.04]$ \\
\hline Giallauria 2008 & $3 / 30$ & $7 / 31$ & 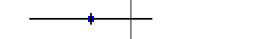 & $6.19 \%$ & $0.44[0.13,1.55]$ \\
\hline Hambrecht 2004 & $1 / 51$ & $7 / 50$ & & $2.57 \%$ & $0.14[0.02,1.1]$ \\
\hline Lewin 1992 & $9 / 58$ & $18 / 58$ & $\longrightarrow$ & $14.27 \%$ & $0.5[0.25,1.02]$ \\
\hline Maddison 2014 & $0 / 85$ & $0 / 86$ & & & Not estimable \\
\hline Mutwalli 2012 & $4 / 28$ & $11 / 21$ & $\longrightarrow$ & $8.99 \%$ & $0.27[0.1,0.74]$ \\
\hline Reid 2012 & $4 / 115$ & $6 / 108$ & - & $6.34 \%$ & $0.63[0.18,2.16]$ \\
\hline Subtotal $(95 \% \mathrm{Cl})$ & 574 & 546 & & $100 \%$ & $0.65[0.46,0.92]$ \\
\hline \multicolumn{6}{|c|}{ Total events: 82 (Exercise), 116 (Usual Care) } \\
\hline \multicolumn{6}{|c|}{ Test for overall effect: $Z=2.46(P=0.01)$} \\
\hline \multicolumn{6}{|c|}{ 1.6.2 Follow-up of $>12$ to 36 months } \\
\hline Belardinelli 2001 & $11 / 59$ & $21 / 59$ & + & $3.72 \%$ & $0.52[0.28,0.99]$ \\
\hline Haskell 1994 & $62 / 145$ & $72 / 155$ & $\star$ & $23.34 \%$ & $0.92[0.71,1.19]$ \\
\hline Shaw 1981 & $109 / 323$ & $113 / 328$ & & $32.76 \%$ & $0.98[0.79,1.21]$ \\
\hline VHSG 2003 & $11 / 98$ & $14 / 99$ & - & $2.74 \%$ & $0.79[0.38,1.66]$ \\
\hline Yu 2004 & $34 / 132$ & $16 / 72$ & 1 & $5.52 \%$ & $1.16[0.69,1.95]$ \\
\hline Zwisler 2008 & $95 / 227$ & $94 / 219$ & + & $31.91 \%$ & $0.98[0.79,1.21]$ \\
\hline Subtotal $(95 \% \mathrm{Cl})$ & 984 & 932 & $\uparrow$ & $100 \%$ & $0.95[0.84,1.07]$ \\
\hline \multicolumn{6}{|c|}{ Total events: 322 (Exercise), 330 (Usual Care) } \\
\hline \multicolumn{6}{|c|}{ Heterogeneity: Tau $^{2}=0 ; \mathrm{Chi}^{2}=4.37, \mathrm{df}=5(\mathrm{P}=0.5) ; \mathrm{I}^{2}=0 \%$} \\
\hline \multicolumn{6}{|c|}{ Test for overall effect: $Z=0.9(P=0.37)$} \\
\hline Subtotal $(95 \% \mathrm{Cl})$ & 0 & 0 & & & Not estimable \\
\hline \multicolumn{6}{|c|}{ Total events: 0 (Exercise), 0 (Usual Care) } \\
\hline \multicolumn{6}{|c|}{ Heterogeneity: Not applicable } \\
\hline Test for overall effec & & & & & \\
\hline
\end{tabular}

\section{ADDITIONAL TABLES}


Table 1. Summary of health-related quality of life (HRQL) scores at follow-up

\begin{tabular}{|c|c|c|c|c|}
\hline \multirow[t]{2}{*}{ Measure of HRQL } & \multicolumn{2}{|c|}{$\begin{array}{l}\text { Mean (SD) outcome values at fol- } \\
\text { low-up }\end{array}$} & \multirow[t]{2}{*}{$P$ value } & \multirow[t]{2}{*}{ Difference between groups } \\
\hline & Exercise & Usual Care & & \\
\hline \multicolumn{5}{|l|}{ Belardinelli 2001} \\
\hline \multicolumn{5}{|c|}{ SF-36 at 6 months follow-up: } \\
\hline Physical functioning & $78(19)$ & $55(20)$ & 0.001 & Exercise $>$ Usual care \\
\hline Physical performance & $75(13)$ & $65(14)$ & 0.01 & Exercise $>$ Usual care \\
\hline Bodily pain & $4(9)$ & $22(10)$ & 0.001 & Exercise > Usual care \\
\hline General health & $68(14)$ & $50(19)$ & 0.001 & Exercise $>$ Usual care \\
\hline Vitality & NR & NR & & \\
\hline Social functioning & $66(10)$ & $69(12)$ & $0.14^{\star}$ & Exercise $=$ Usual care \\
\hline Emotional performance & NR & NR & & \\
\hline Mental health & $65(12)$ & $48(15)$ & 0.01 & Exercise $>$ Usual care \\
\hline \multicolumn{5}{|c|}{ SF-36 at 12 months follow-up: } \\
\hline Physical functioning & $82(18)$ & $54(20)$ & 0.001 & Exercise $>$ Usual care \\
\hline Physical performance & $76(9)$ & $58(14)$ & 0.01 & Exercise $>$ Usual care \\
\hline Bodily pain & $4(9)$ & $32(12)$ & 0.001 & Exercise $>$ Usual care \\
\hline General health & $70(14)$ & $50(18)$ & 0.001 & Exercise > Usual care \\
\hline Vitality & NR & NR & & \\
\hline Social functioning & $68(11)$ & $68(12)$ & $1.00^{*}$ & Exercise $=$ Usual care \\
\hline Emotional performance & NR & NR & & \\
\hline Mental health & $70(14)$ & $45(15)$ & 0.001 & Exercise > Usual care \\
\hline
\end{tabular}

\section{Bell 1998}

Nottingham health profile at

10.5 months follow-up:

\begin{tabular}{|c|c|c|c|c|}
\hline Energy & $17.6(27.1)$ & $18.3(29.8)$ & $0.87^{\star \star}$ & Exercise $=$ Usual care \\
\hline Pain & $2.8(8.8)$ & $4.82(11.9)$ & $<0.05$ & Exercise $>$ Usual care \\
\hline Emotional reactions & $6.4(17.0)$ & $12.2(19.9)$ & $<0.001$ & Exercise $>$ Usual care \\
\hline Sleep & $7.5(18.4)$ & $20.5(27.8)$ & $<0.001$ & Exercise > Usual care \\
\hline
\end{tabular}


Table 1. Summary of health-related quality of life (HRQL) scores at follow-up (Continued)

\begin{tabular}{|c|c|c|c|c|}
\hline Social isolation & $2.3(10.6)$ & $4.0(13.3)$ & $0.37^{\star}$ & Exercise $=$ Usual care \\
\hline Physical mobility & $8.4(11.1)$ & $8.9(14.5)$ & $0.82^{\star \star}$ & Exercise $=$ Usual care \\
\hline \multicolumn{5}{|l|}{ Bettencourt 2005} \\
\hline \multicolumn{5}{|l|}{ SF-36 at 1 year follow-up: } \\
\hline Physical functioning & 70 & 62 & $\mathrm{NS}^{*}$ & Exercise $=$ Usual care \\
\hline Physical performance & 66 & 57 & $\mathrm{NS}^{*}$ & Exercise $=$ Usual care \\
\hline Bodily pain & 73 & 65 & $\mathrm{NS}^{*}$ & Exercise $=$ Usual care \\
\hline General health & 57 & 46 & $<0.02$ & Exercise $>$ Usual care \\
\hline Vitality & 62 & 47 & $<0.02$ & Exercise $>$ Usual care \\
\hline Social functioning & 73 & 66 & $\mathrm{NS}^{*}$ & Exercise $=$ Usual care \\
\hline Emotional performance & 65 & 58 & $\mathrm{NS}^{*}$ & Exercise $=$ Usual care \\
\hline Mental health & 87 & 75 & $\mathrm{NS}^{*}$ & Exercise $=$ Usual care \\
\hline Mental component & 71 & 57 & 0.02 & Exercise $>$ Usual care \\
\hline Physical component & 63 & 57 & $\mathrm{NS}^{*}$ & Exercise $=$ Usual care \\
\hline
\end{tabular}

\section{Briffa 2005}

\section{SF-36 at 6 months follow-up:}

\begin{tabular}{|c|c|c|c|c|}
\hline & $\Delta(95 \% \mathrm{Cl})$ & $\Delta(95 \% \mathrm{Cl})$ & & \\
\hline Physical functioning & 7.1 (1 to 13$)$ & $15.9(-8$ to 23$)$ & $N S^{*}$ & Exercise $=$ Usual care \\
\hline Physical performance & 75 (0 to 100$)$ & 75 ( 0 to 100$)$ & $N S^{*}$ & Exercise $=$ Usual care \\
\hline Bodily pain & 19.2 (11 to 27 ) & 26.6 (18 to 35$)$ & $N S^{*}$ & Exercise $=$ Usual care \\
\hline General health & $-0.6(-5$ to 4$)$ & $0.1(-6$ to 6$)$ & $N S^{*}$ & Exercise $=$ Usual care \\
\hline Vitality & $3.7(-2$ to 9$)$ & 7.1 (1 to 13$)$ & $N S^{*}$ & Exercise $=$ Usual care \\
\hline Social functioning & 14.1 (7 to 21$)$ & $19.6(10$ to 29$)$ & $N S^{*}$ & Exercise $=$ Usual care \\
\hline Emotional performance & 33.3 (33 to 100$)$ & $33.3(0$ to 100$)$ & $N S^{*}$ & Exercise $=$ Usual care \\
\hline Mental health & $1.4(-3$ to 5$)$ & $0.5(-4$ to 5$)$ & $N S^{*}$ & Exercise $=$ Usual care \\
\hline \multicolumn{5}{|l|}{ SF-36 at 1 year follow-up: } \\
\hline & $\Delta(95 \% \mathrm{Cl})$ & $\Delta(95 \% \mathrm{Cl})$ & & \\
\hline Physical functioning & $6.8(-1$ to 14$)$ & 17.6 (10 to 25$)$ & 0.04 & Exercise $>$ Usual care \\
\hline
\end{tabular}


Table 1. Summary of health-related quality of life (HRQL) scores at follow-up (Continued)

\begin{tabular}{|c|c|c|c|c|}
\hline Physical performance & 75 (12 to 30$)$ & 100 (0 to 100$)$ & $N S^{*}$ & Exercise $=$ Usual care \\
\hline Bodily pain & $20.9(-2$ to 7$)$ & 30.2 (23 to 37 ) & $N S^{*}$ & Exercise $=$ Usual care \\
\hline General health & $2.2(-2$ to 7$)$ & $2.7(-3$ to 5$)$ & $N S^{*}$ & Exercise $=$ Usual care \\
\hline Vitality & 6.9 (1 to 12$)$ & 11.9 (6 to 18$)$ & $N S^{*}$ & Exercise $=$ Usual care \\
\hline Social functioning & 16.4 (9 to 23$)$ & 23.6 (14 to 33 ) & $N S^{*}$ & Exercise $=$ Usual care \\
\hline Emotional performance & $33.3(33$ to 100$)$ & 33.3 (33 to 100$)$ & $N^{*}$ & Exercise $=$ Usual care \\
\hline Mental health & $3.9(0$ to 8$)$ & 3.6 (-1 to 9$)$ & $N S^{*}$ & Exercise $=$ Usual care \\
\hline
\end{tabular}

\section{Engblom 1992}

Nottingham health profile at 5 years follow-up:

\begin{tabular}{lcccc}
\hline Energy & 18 & 25 & 0.08 & Exercise = Usual care \\
\hline Pain & 12 & 18 & 0.07 & Exercise = Usual care \\
\hline Emotional reactions & 14 & 21 & 0.27 & Exercise = Usual care \\
\hline Sleep & 24 & 29 & 0.42 & Exercise = Usual care \\
\hline Social isolation & 7 & 9 & 0.42 & Exercise $=$ Usual care \\
\hline Physical mobility & 6 & 14 & 0.005 & Exercise $>$ Usual care
\end{tabular}

\section{Heller 1993}

QLMI at 6 months follow-up:

\begin{tabular}{lcccc}
\hline Emotional & $5.4(1.1)$ & $5.2(1.2)$ & 0.04 & Exercise $>$ Usual care \\
\hline Physical & $5.4(1.2)$ & $5.2(1.3)$ & $0.17^{\star}$ & Exercise $=$ Usual care \\
\hline Social & $5.9(1.1)$ & $5.8(1.1)$ & $0.35^{\star}$ & Exercise = Usual care \\
\hline
\end{tabular}

\section{Hofman-Bang 1999}

\section{AP-QLQ at 12 months follow-up:}

\begin{tabular}{lllll}
\hline Physical activity & 4.9 & 4.3 & $<0.05$ & Exercise $>$ Usual care \\
\hline Somatic symptoms & NR & NR & NS & Exercise = Usual care \\
\hline Emotional distress & NR & NR & NS & Exercise = Usual care \\
\hline Life satisfaction & NR & NR & NS & Exercise = Usual care \\
\hline
\end{tabular}

\section{Houle 2012}

\section{Quality of Life Index-cardiac version III at 6 months follow-up:}


Table 1. Summary of health-related quality of life (HRQL) scores at follow-up (Continued)

\begin{tabular}{lcccc} 
Health and functional score & $26(5.1)$ & $24.5(5.3)$ & 0.048 & Exercise $>$ Usual care \\
\hline Psychological/spiritual score & $25.6(5.8)$ & $25.5(3.8)$ & 0.383 & Exercise = Usual care \\
\hline Social and economic score & $25.7(3.8)$ & $25.4(4.7)$ & 0.392 & Exercise = Usual care \\
\hline Family score & $28.1(2.5)$ & $26.7(4.3)$ & 0.048 & Exercise $>$ Usual care \\
\hline Overall & $26.2(4.3)$ & $25.8(4.1)$ & 0.057 & Exercise = Usual care \\
\hline Quality of Life Index-cardiac version III at 12 months follow-up: & & \\
\hline Health and functional score & $27.8(2.0)$ & $25.3(4.6)$ & 0.036 & Exercise $>$ Usual care \\
\hline Psychological/spiritual score & $27.4(2.5)$ & $26.2(4.0)$ & 0.336 & Exercise $=$ Usual care \\
\hline Social and economic score & $27.2(3.0)$ & $25.9(5.2)$ & 0.638 & Exercise = Usual care \\
\hline Family score & $28(2.6)$ & $26.8(5.0)$ & 0.092 & Exercise = Usual care
\end{tabular}

\section{Maddison 2014}

EQ-5D at 24 weeks follow-up:

$0.86 \quad 0.83 \quad 0.23 \quad$ Exercise $=$ Usual care

\section{SF-36 at 24 weeks follow-up:}

\begin{tabular}{lcccl}
\hline Physical functioning & 52.9 & 51.9 & 0.20 & Exercise $=$ Usual care \\
\hline Role physical & 52.6 & 50.8 & 0.08 & Exercise $=$ Usual care \\
\hline Bodily pain & 52.4 & 51.9 & 0.71 & Exercise $=$ Usual care \\
\hline General health & 55.3 & 53.2 & 0.03 & Exercise $>$ Usual care \\
\hline Vitality & 55.7 & 55.9 & 0.79 & Exercise = Usual care \\
\hline Social Functioning & 53.3 & 52.4 & 0.42 & Exercise $=$ Usual care \\
\hline Role emotional & 51.4 & 51.6 & 0.81 & Exercise $=$ Usual care \\
\hline Mental health & 54.6 & 54.0 & 0.61 & Exercise $=$ Usual care \\
\hline
\end{tabular}

\section{Mutwalli 2012}

SF-36 Health status score at 6 months follow-up:

\begin{tabular}{llll}
\hline $90.14(4.83)$ & $60.55(16.21)$ & 0.000 & Exercise $>$ Usual care \\
\hline
\end{tabular}

\section{Oerkild 2012}

\section{SF-36 at 12 months follow-up:}


Table 1. Summary of health-related quality of life (HRQL) scores at follow-up (Continued)

\begin{tabular}{|c|c|c|c|c|}
\hline & $\Delta(95 \% \mathrm{Cl})$ & $\Delta(95 \% \mathrm{Cl})$ & & \\
\hline SF 12 PCS & $-1.1(-5.3$ to 3.1$)$ & $-1.4(-5.2$ to 2.3$)$ & $N S^{*}$ & Exercise $=$ Usual care \\
\hline SF 12 MCS & $-1.4(-6.1$ to 3.3$)$ & $-0.3(-4.6$ to 4.0$)$ & $N S^{*}$ & Exercise $=$ Usual care \\
\hline \multicolumn{5}{|c|}{ Oldridge 1991} \\
\hline \multicolumn{5}{|c|}{ QLMI at 4 months follow-up: } \\
\hline Limitations & 54 & 54 & NS & Exercise $=$ Usual care \\
\hline Emotions & 103 & 101 & NS & Exercise $=$ Usual care \\
\hline \multicolumn{5}{|c|}{ QLMI at 8 months follow-up: } \\
\hline Limitations & 54 & 54 & NS & Exercise $=$ Usual care \\
\hline Emotions & 103 & 103 & NS & Exercise $=$ Usual care \\
\hline \multicolumn{5}{|c|}{ QLMI at 12 months follow-up: } \\
\hline Limitations & 54 & 55 & NS & Exercise $=$ Usual care \\
\hline Emotions & 105 & 102 & NS & Exercise $=$ Usual care \\
\hline
\end{tabular}

\section{Reid 2012}

MacNew at 12 months fol-

low-up:

\begin{tabular}{lcccl}
\hline Global score & $5.8(0.6)$ & $5.6(0.8)$ & 0.112 & Exercise $=$ Usual care \\
\hline Emotional subscale & $5.6(0.6)$ & $5.4(0.7)$ & 0.038 & Exercise $>$ Usual care \\
\hline Social subscale & $6.3(0.8)$ & $6.0(1.0)$ & 0.162 & Exercise $=$ Usual care \\
\hline Physical subscale & $6.0(0.8)$ & $5.8(1.0)$ & 0.031 & Exercise $>$ Usual care
\end{tabular}

\section{Sandstrom 2005}

Time Trade Off (TTO) at 12 months follow-up:

$0.86(0.23) \quad 0.85(0.21) \quad \mathrm{NS}^{*} \quad$ Exercise $=$ Usual care

\section{EuroQol Part one at 12 months follow-up:}

$0.87(0.15) \quad 0.86(0.16) \quad N^{*} \quad$ Exercise $=$ Usual care

\section{EuroQol Part two at 12 months follow-up:}

$7.6(1.46) \quad 7.43(1.46) \quad$ NS $^{*} \quad$ Exercise $=$ Usual care

\section{Stahle 1999}

\section{Karolinska Questionnaire at 12 months follow-up:}


Table 1. Summary of health-related quality of life (HRQL) scores at follow-up (Continued)

\begin{tabular}{|c|c|c|c|c|}
\hline Chest pain & $0.6(1.2)$ & $0.4(1.3)$ & NS & Exercise $=$ Usual care \\
\hline Shortness of breath & $0.4(1.1)$ & $0.2(1.0)$ & NS & Exercise $=$ Usual care \\
\hline Dizziness & $-0.1(1.1)$ & $0.2(0.9)$ & NS & Exercise $=$ Usual care \\
\hline Palpitation & $-0.1(1.0)$ & $0.1(0.9)$ & NS & Exercise $=$ Usual care \\
\hline Cognitive ability & $-0.1(0.6)$ & $0.0(0.7)$ & NS & Exercise $=$ Usual care \\
\hline Alertness & $0.0(0.9)$ & $0.1(0.8)$ & NS & Exercise $=$ Usual care \\
\hline Quality of sleep & $0.0(0.5)$ & $0.1(0.5)$ & NS & Exercise $=$ Usual care \\
\hline Physical ability & $0.2(0.7)$ & $0.1(0.4)$ & NS & Exercise $=$ Usual care \\
\hline Daily activity & $0.3(0.5)$ & $0.1(0.5)$ & NS & Exercise $=$ Usual care \\
\hline Depression & $0.1(0.3)$ & $0.1(0.2)$ & NS & Exercise $=$ Usual care \\
\hline Self perceived health & $0.5(1.3)$ & $0.3(1.0)$ & NS & Exercise $=$ Usual care \\
\hline "Ladder of Life" present & $1.2(1.2)$ & $0.9(1.8)$ & NS & Exercise $=$ Usual care \\
\hline "Ladder of Life" future & $0.8(2.7)$ & $0.4(2.3)$ & NS & Exercise $=$ Usual care \\
\hline Fitness & $0.6(1.4)$ & $0.4(1.0)$ & NS & Exercise $=$ Usual care \\
\hline Physical ability & $0.7(1.0)$ & $0.4(1.1)$ & NS & Exercise $=$ Usual care \\
\hline
\end{tabular}

\section{Toobert 2000}

\section{SF-36 at 24 months follow-up:}

\begin{tabular}{lllll}
\hline Physical functioning & NR & NR & NS & Exercise $=$ Usual care \\
\hline Physical performance & NR & NR & NS & Exercise $=$ Usual care \\
\hline Bodily pain & NR & NR & NS & Exercise $=$ Usual care \\
\hline General health & NR & NR & $<0.05$ & Exercise $>$ Usual care \\
\hline Vitality & NR & NR & NS & Exercise $=$ Usual care \\
\hline Social functioning & NR & NR & $<0.05$ & Exercise $>$ Usual care \\
\hline Emotional performance & NR & NR & NS & Exercise $=$ Usual care \\
\hline Mental health & NR & NR & NS & Exercise $=$ Usual care \\
\hline
\end{tabular}

\section{Wang 2012}

SF-36 at 6 months follow-up:

\begin{tabular}{|c|c|c|c|c|}
\hline Physical functioning & $80.8(13.7)$ & $73.2(13.0)$ & $<0.001$ & Exercise $>$ Usual care \\
\hline
\end{tabular}


Table 1. Summary of health-related quality of life (HRQL) scores at follow-up (Continued)

\begin{tabular}{|c|c|c|c|c|}
\hline Physical performance & $68.2(17.3)$ & $56.2(46.8)$ & 0.015 & Exercise $>$ Usual care \\
\hline Bodily pain & $68.2(17.3)$ & $63.5(14.6)$ & 0.012 & Exercise $>$ Usual care \\
\hline General health & $57.4(20.3)$ & $49.0(16.2)$ & 0.017 & Exercise $>$ Usual care \\
\hline Vitality & $66.3(17.3)$ & $56.4(21.7)$ & 0.002 & Exercise $>$ Usual care \\
\hline Social functioning & $71.3(21.4)$ & $65.8(18.0)$ & 0.031 & Exercise $>$ Usual care \\
\hline Emotional performance & $80.8(37.9)$ & $75.9(39.7)$ & 0.12 & Exercise $=$ Usual care \\
\hline Mental health & $73.5(17.1)$ & $65.4(20.7)$ & 0.011 & Exercise $>$ Usual care \\
\hline \multicolumn{5}{|l|}{ MIDAS at 6 months } \\
\hline Physical Activity & $37.7(11.2)$ & $42.6(12.3)$ & $<0.001$ & Exercise $>$ Usual care \\
\hline Insecurity & $28.7(9.7)$ & $33.4(13.8)$ & $<0.001$ & Exercise $>$ Usual care \\
\hline Emotional reaction & $30.4(12.8)$ & $34.8(14.4)$ & 0.008 & Exercise $>$ Usual care \\
\hline Dependency & $27.6(9.4)$ & $31.8(16.6)$ & 0.001 & Exercise $>$ Usual care \\
\hline Diet & $36.8(15.4)$ & $43.6(20.7)$ & 0.40 & Exercise $=$ Usual care \\
\hline Concerns over meds & $29.4(12.6)$ & $37.7(18.0)$ & $<0.001$ & Exercise $>$ Usual care \\
\hline Side Effects & $28.2(11.1)$ & $30.8(14.3)$ & 0.30 & Exercise $>$ Usual care \\
\hline
\end{tabular}

\section{West 2012}

SF-36 at 12 months follow-up:

\begin{tabular}{|c|c|c|c|c|}
\hline Physical function & $65(29)$ & $64(30)$ & $\mathrm{NS}^{*}$ & Exercise $=$ Usual care \\
\hline Role physical & $69(31)$ & $67(33)$ & $\mathrm{NS}^{*}$ & Exercise $=$ Usual care \\
\hline Role emotional & $85(23)$ & $85(25)$ & $\mathrm{NS}^{*}$ & Exercise $=$ Usual care \\
\hline Social function & $81(28)$ & $79(29)$ & $\mathrm{NS}^{*}$ & Exercise $=$ Usual care \\
\hline Mental health & $76(13)$ & $76(13)$ & $\mathrm{NS}^{*}$ & Exercise $=$ Usual care \\
\hline Energy /vitality & $65(24)$ & $65(24)$ & $\mathrm{NS}^{*}$ & Exercise $=$ Usual care \\
\hline Pain & $69(28)$ & $68(29)$ & $\mathrm{NS}^{*}$ & Exercise $=$ Usual care \\
\hline Health Perception & $58(25)$ & $57(25)$ & $\mathrm{NS}^{*}$ & Exercise $=$ Usual care \\
\hline
\end{tabular}

\section{Yu 2003}

SF-36 at 8 months follow-up:

\begin{tabular}{|c|c|c|c|c|}
\hline Physical functioning & $88(12)$ & $82(17)$ & $0.03^{\star}$ & Exercise > Usual care \\
\hline
\end{tabular}


Table 1. Summary of health-related quality of life (HRQL) scores at follow-up (Continued)

\begin{tabular}{|c|c|c|c|c|}
\hline Physical performance & $75(33)$ & $66(35)$ & $0.18^{\star}$ & Exercise $=$ Usual care \\
\hline Bodily pain & $80(25)$ & $80(25)$ & $1.00^{\star}$ & Exercise $=$ Usual care \\
\hline General health & $64(26)$ & $60(28)$ & $0.45^{\star}$ & Exercise $=$ Usual care \\
\hline Vitality & $79(18)$ & $65(17)$ & 0.0001 & Exercise $>$ Usual care \\
\hline Social functioning & $89(27)$ & $82(28)$ & 0.15 & Exercise $=$ Usual care \\
\hline Emotional performance & $93(18)$ & $83(35)$ & 0.05 & Exercise $=$ Usual care \\
\hline Mental health & $84(16)$ & $80(15)$ & 0.2 & Exercise $=$ Usual care \\
\hline \multicolumn{5}{|c|}{ SF-36 at 24 months follow-up: } \\
\hline Physical functioning & $88(13)$ & $87(9)$ & $0.67^{\star}$ & Exercise $=$ Usual care \\
\hline Physical performance & $80(32)$ & $79(30)$ & $0.87^{\star}$ & Exercise $=$ Usual care \\
\hline Bodily pain & $81(21)$ & $85(20)$ & $0.33^{*}$ & Exercise $=$ Usual care \\
\hline General health & $64(20)$ & $61(18)$ & $0.43^{\star}$ & Exercise $=$ Usual care \\
\hline Vitality & $73(21)$ & $73(17)$ & $1.00^{\star}$ & Exercise $=$ Usual care \\
\hline Social functioning & $79(30)$ & $90(18)$ & $0.04^{\star}$ & Exercise $>$ Usual care \\
\hline Emotional performance & $89(25)$ & $93(25)$ & $0.42^{\star}$ & Exercise $=$ Usual care \\
\hline Mental health & $85(14)$ & $85(12)$ & $1.00^{\star}$ & Exercise $=$ Usual care \\
\hline
\end{tabular}

\section{Zwisler 2008}

\section{SF-36 at 12 months follow-up:}

\begin{tabular}{lllll}
\hline Physical Component Score & $45.2(9.8)$ & $46.4(9.8)$ & $0.39^{\star}$ & Exercise = Usual care \\
\hline Mental Component Score & $50.6(10.8)$ & $48.4(11.5)$ & $0.16^{\star}$ & Exercise = Usual care \\
\hline
\end{tabular}

Short Form-36 (SF-36); QLMI=Quality of Life After Myocardial Infarction questionnaire; AP-QLQ=Angina Pectoris-Quality of Life questionnaire; NR=not reported; NS=not significant

${ }^{*}$ Calculated by authors of this report based on independent two group $t$ test.

${ }^{\star *}$ Adjusted for baseline difference between groups.

Exercise $=$ Usual care: no statistically significant difference $(P>0.05)$ between exercise and usual care groups at follow up Exercise $>$ Usual care: statistically significant difference $(P<0.05)$ between exercise and usual care groups at follow up NS*: The authors of this review have inferred a $\mathrm{P}$ value of $>0.05$ based either on the $95 \% \mathrm{Cl}$, or from narrative in the paper, rather than from directly observing the P-value. 
Table 2. Summary of costs of exercise-based rehabilitation and usual care

\begin{tabular}{|c|c|c|c|c|c|c|c|}
\hline Author/year & Briffa 2005 & $\begin{array}{l}\text { Hambrecht } \\
2004\end{array}$ & Kovoor $2006^{1}$ & $\begin{array}{l}\text { Maddison } \\
2014\end{array}$ & $\begin{array}{l}\text { Marchionni } \\
2003\end{array}$ & Oldridge $1991^{2}$ & Yu 2004 \\
\hline Follow-up (months) & 12 & 12 & 12 & 6 & 14 & 12 & 24 \\
\hline Year of costs (currency) & 1998 (\$Aus) & NR & 1999 (\$AUD) & $\begin{array}{l}\text { NR (€; Eu- } \\
\text { ros) }\end{array}$ & 2000 (\$USD) & 1991 (\$USD) & 2003 (\$USD) \\
\hline
\end{tabular}

\section{Cost of rehabilitation}

\begin{tabular}{|c|c|c|c|c|c|c|c|}
\hline Mean cost/patient & $\$ 694$ & NR & $\$ 394$ & $€ 127$ & $\$ 5246$ & $\$ 670$ & NR \\
\hline Costs considered & $\begin{array}{l}\text { Details of } \\
\text { costed ele- } \\
\text { ments not } \\
\text { provided }\end{array}$ & NR & $\begin{array}{l}\text { staff, assessments, coun- } \\
\text { selling, education, patient } \\
\text { travel }\end{array}$ & NR & NR & $\begin{array}{l}\text { space, equipment, } \\
\text { staff, literature re- } \\
\text { sources, operating } \\
\text { costs, parking, pa- } \\
\text { tients costs }\end{array}$ & NR \\
\hline
\end{tabular}

\section{Total healthcare costs}

\begin{tabular}{|c|c|c|c|c|c|c|c|}
\hline $\begin{array}{l}\text { Rehabilitation mean cost/pa- } \\
\text { tient }\end{array}$ & $\$ 4937$ & $\$ 3708 \pm 156$ & NR & NR & $\$ 17272$ & NR & $\$ 15292$ \\
\hline Usual care mean cost/patient & $\$ 4541$ & $\$ 6086 \pm 370$ & NR & NR & $\$ 12433$ & NR & $\$ 15707$ \\
\hline Difference mean/patient ${ }^{\star}$ & $\$ 395$ & $-\$ 2378$ & NR & NR & $\$ 4839$ & $\$ 480$ & $-\$ 415$ \\
\hline$P$ value for cost difference & 0.74 & $P<0.001$ & $P>0.05$ (see below) & NR & NR & NR & $P>0.05$ \\
\hline $\begin{array}{l}\text { Additional healthcare costs } \\
\text { considered }\end{array}$ & $\begin{array}{l}\text { hospitalisa- } \\
\text { tions, phar- } \\
\text { maceuticals, } \\
\text { tests, consul- } \\
\text { tations, re- } \\
\text { habilitation, } \\
\text { patient ex- } \\
\text { penses, am- } \\
\text { bulance }\end{array}$ & $\begin{array}{l}\text { rehospital- } \\
\text { isations, } \\
\text { revasculari- } \\
\text { sation, cycle } \\
\text { ergometers, } \\
\text { training fa- } \\
\text { cilities, and } \\
\text { supervising } \\
\text { staff }\end{array}$ & $\begin{array}{l}\text { phone calls }(P=0.10) \text {; hospi- } \\
\text { tal admissions }(P=0.11) \text {; gat- } \\
\text { ed heart pool scan }(P=0.50) \text {; } \\
\text { exercise stress test }(P=0.72) \text {; } \\
\text { other diagnostics }(P=0.37) \text {; } \\
\text { visits to general practitioner } \\
(P=0.61) \text {, specialist doctor ( } P \\
=0.35) \text {, or health-care profes- } \\
\text { sional }(P=0.31)\end{array}$ & NR & NR & $\begin{array}{l}\text { Service utilisation, } \\
\text { physician costs, emer- } \\
\text { gency costs, in-patient } \\
\text { days, allied health, } \\
\text { other rehabilitation } \\
\text { visits }\end{array}$ & $\begin{array}{l}\text { hospitalisa- } \\
\text { tions; revas- } \\
\text { cularisations; } \\
\text { private clinic } \\
\text { visit; cardiac } \\
\text { clinic visits; } \\
\text { public non- } \\
\text { cardiac visits; } \\
\text { casualty vis- } \\
\text { its; drugs }\end{array}$ \\
\hline
\end{tabular}

Cost-effectiveness 
Table 2. Summary of costs of exercise-based rehabilitation and usual care (Continued)

\begin{tabular}{|c|c|c|c|c|c|c|c|}
\hline $\begin{array}{l}\text { Rehabilitation mean health } \\
\text { care benefits }\end{array}$ & $\begin{array}{l}\text { Utility-Based } \\
\text { Quality of life } \\
- \\
\text { Heart ques- } \\
\text { tionnaire: } \\
0.026 \text { (95\% } \\
\mathrm{Cl}, 0.013 \text { to } \\
0.039)\end{array}$ & NR & NR & NR & NR & NR & NR \\
\hline $\begin{array}{l}\text { Usual care mean health care } \\
\text { benefit }\end{array}$ & $\begin{array}{l}\text { Utility } 0.010 \\
(95 \% \mathrm{Cl} \text {, } \\
-0.001 \text { to } \\
0.022)\end{array}$ & NR & NR & NR & NR & NR & NR \\
\hline $\begin{array}{l}\text { Incremental mean health care } \\
\text { benefit }\end{array}$ & $\begin{array}{l}\text { Utility } 0.013 \\
\text { (95\% Cl, NR), } \\
\mathrm{P}=0.38 \text {; } \\
+0.009 \text { QALYS }\end{array}$ & NR & NR & NR & NR & $\begin{array}{l}0.052 \text { QALYS }(95 \% \mathrm{Cl} \text {, } \\
0.007 \text { to } 0.1)\end{array}$ & 0.06 QALYS \\
\hline $\begin{array}{l}\text { Incremental cost effective- } \\
\text { ness ratio/patient }\end{array}$ & $\begin{array}{l}+\$ 42,535 \text { per } \\
\text { QALY. Exten- } \\
\text { sive sensitivi- } \\
\text { ty analyses re- } \\
\text { ported }\end{array}$ & NR & NR & $\begin{array}{l}+€ 15,247 \\
\text { per QALY }\end{array}$ & NR & $+\$ 9,200$ per QALY & $\begin{array}{l}-\$ 650 \text { per } \\
\text { QALY }\end{array}$ \\
\hline
\end{tabular}

${ }^{1}$ Cost data for this study is reported in Hall 2002

2 cost data for this study is reported in Oldridge 1993 
Table 3. Results of univariate meta-regression analysis for total mortality

\begin{tabular}{|c|c|c|c|c|}
\hline Explanatory variable ( $\mathrm{n}$ trials) & $\begin{array}{l}\text { Exp(s- } \\
\text { lope })^{\star}\end{array}$ & $\begin{array}{l}95 \% \text { Confidence } \\
\text { interval } \\
\text { Univariate } P \text { value }\end{array}$ & $\begin{array}{l}\text { Propor- } \\
\text { tion of } \\
\text { variation } \\
\text { explained }\end{array}$ & Interpretation \\
\hline $\begin{array}{l}\text { Case mix } \\
\text { (\% MI patients) }(n=41)\end{array}$ & $\mathrm{RR}=0.998$ & $\begin{array}{l}0.996 \text { to } 1.000 \\
P=0.93\end{array}$ & $0 \%$ & $\begin{array}{l}\text { No evidence that risk ratio is associ- } \\
\text { ated with case mix }\end{array}$ \\
\hline $\begin{array}{l}\text { Dose of exercise (number of weeks of ex- } \\
\text { ercise training } x \text { average number of ses- } \\
\text { sions/week } x \text { average duration of session } \\
\text { in } \min \text { ) }(n=29)\end{array}$ & $\mathrm{RR}=1.000$ & $\begin{array}{l}1.000 \text { to } 1.000 \\
P=0.74\end{array}$ & $0 \%$ & $\begin{array}{l}\text { No evidence that risk ratio is associ- } \\
\text { ated with increased dose of exercise }\end{array}$ \\
\hline $\begin{array}{l}\text { Type of CR } \\
\text { (exercise only vs comprehensive CR) ( } n= \\
42 \text { ) }\end{array}$ & $\mathrm{RR}=1.084$ & $\begin{array}{l}0.909 \text { to } 1.292 \\
P=1.00\end{array}$ & $0 \%$ & $\begin{array}{l}\text { No evidence that risk ratio is associ- } \\
\text { ated with type of } C R\end{array}$ \\
\hline Duration of follow-up (months) $(n=41)$ & $\mathrm{RR}=1.001$ & $\begin{array}{l}1.000 \text { to } 1.002 \\
P=1.00\end{array}$ & $0 \%$ & $\begin{array}{l}\text { No evidence that risk ratio is associ- } \\
\text { ated with duration of follow-up }\end{array}$ \\
\hline $\begin{array}{l}\text { Year of publication } \\
\text { (pre } 1995 \text { vs post } 1995)(n=42)\end{array}$ & $\mathrm{RR}=1.006$ & $\begin{array}{l}0.999 \text { to } 1.013 \\
P=1.00\end{array}$ & $0 \%$ & $\begin{array}{l}\text { No evidence that risk ratio is associ- } \\
\text { ated with year of publication }\end{array}$ \\
\hline Setting (centre vs home) $(n=42)$ & $\mathrm{RR}=1.012$ & $\begin{array}{l}0.822 \text { to } 1.246 \\
P=1.00\end{array}$ & $0 \%$ & $\begin{array}{l}\text { No evidence that risk ratio is associ- } \\
\text { ated with setting }\end{array}$ \\
\hline $\begin{array}{l}\text { Risk of bias (low risk in } \geq 5 \text { items } v<5 \\
\text { items) }(n=42)\end{array}$ & $\mathrm{RR}=1.033$ & $\begin{array}{l}0.985 \text { to } 1.083 \\
P=1.00\end{array}$ & $0 \%$ & $\begin{array}{l}\text { No evidence that risk ratio is associ- } \\
\text { ated with risk of bias }\end{array}$ \\
\hline Study location $(n=42)$ & $\mathrm{RR}=1.071$ & $\begin{array}{l}0.915 \text { to } 1.254 \\
P=1.00\end{array}$ & $0 \%$ & $\begin{array}{l}\text { No evidence that risk ratio is associ- } \\
\text { ated with study location }\end{array}$ \\
\hline Sample size $(n=42)$ & $\mathrm{RR}=1.192$ & $\begin{array}{l}0.732 \text { to } 1.940 \\
P=1.00\end{array}$ & $0 \%$ & $\begin{array}{l}\text { No evidence that risk ratio is associ- } \\
\text { ated with sample size }\end{array}$ \\
\hline
\end{tabular}

P-values adjusted for multiple testing

Table 4. Results of univariate meta-regression analysis for cardiovascular mortality

\begin{tabular}{|c|c|c|c|c|}
\hline Explanatory variable (n trials) & $\begin{array}{l}\text { Exp(s- } \\
\text { lope })^{\star}\end{array}$ & $\begin{array}{l}\text { 95\% Confidence } \\
\text { interval } \\
\text { Univariate P value }\end{array}$ & $\begin{array}{l}\text { Propor- } \\
\text { tion of } \\
\text { variation } \\
\text { explained }\end{array}$ & Interpretation \\
\hline $\begin{array}{l}\text { Case mix } \\
\text { (\% MI patients) }(n=22)\end{array}$ & $\mathrm{RR}=1.003$ & $\begin{array}{l}0.994 \text { to } 1.011 \\
\mathrm{P}=1.00\end{array}$ & $0 \%$ & $\begin{array}{l}\text { No evidence that risk ratio is associ- } \\
\text { ated with case mix }\end{array}$ \\
\hline $\begin{array}{l}\text { Dose of exercise (number of weeks of ex- } \\
\text { ercise training } x \text { average number of ses- }\end{array}$ & $\mathrm{RR}=1.000$ & 1.000 to 1.000 & $0 \%$ & $\begin{array}{l}\text { No evidence that risk ratio is associ- } \\
\text { ated with increased dose of exercise }\end{array}$ \\
\hline
\end{tabular}


Table 4. Results of univariate meta-regression analysis for cardiovascular mortality (Continued) sions/week $x$ average duration of session in $\min )(n=18)$

\begin{tabular}{|c|c|c|c|c|}
\hline $\begin{array}{l}\text { Type of CR } \\
\text { (exercise only vs comprehensive CR) ( } \mathrm{n}= \\
21 \text { ) }\end{array}$ & $\mathrm{RR}=0.802$ & $\begin{array}{l}0.560 \text { to } 1.148 \\
P=0.99\end{array}$ & $0 \%$ & $\begin{array}{l}\text { No evidence that risk ratio is associ- } \\
\text { ated with type of } C R\end{array}$ \\
\hline Duration of follow-up (months) $(n=21)$ & $\begin{array}{l}\mathrm{RR}= \\
0.994\end{array}$ & $\begin{array}{l}0.988 \text { to } 1.000 \\
P=0.27\end{array}$ & $0 \%$ & $\begin{array}{l}\text { No evidence that risk ratio is associ- } \\
\text { ated with duration of follow-up }\end{array}$ \\
\hline $\begin{array}{l}\text { Year of publication } \\
\text { (pre } 1995 \text { vs post } 1995)(n=24)\end{array}$ & $\mathrm{RR}=0.990$ & $\begin{array}{l}0.970 \text { to } 1.012 \\
P=0.99\end{array}$ & $0 \%$ & $\begin{array}{l}\text { No evidence that risk ratio is associ- } \\
\text { ated with year of publication }\end{array}$ \\
\hline Setting (centre vs home) $(n=24)$ & $\mathrm{RR}=1.033$ & $\begin{array}{l}0.863 \text { to } 1.24 \\
P=0.98\end{array}$ & $0 \%$ & $\begin{array}{l}\text { No evidence that risk ratio is associ- } \\
\text { ated with setting }\end{array}$ \\
\hline $\begin{array}{l}\text { Risk of bias (low risk in } \geq 5 \text { items } v<5 \\
\text { items) }(n=24)\end{array}$ & $\mathrm{RR}=0.914$ & $\begin{array}{l}0.816 \text { to } 1.022 \\
P=1.00\end{array}$ & $0 \%$ & $\begin{array}{l}\text { No evidence that risk ratio is associ- } \\
\text { ated with risk of bias }\end{array}$ \\
\hline Study location $(n=24)$ & $\mathrm{RR}=0.979$ & $\begin{array}{l}0.735 \text { to } 1.303 \\
P=1.00\end{array}$ & $0 \%$ & $\begin{array}{l}\text { No evidence that risk ratio is associ- } \\
\text { ated with study location }\end{array}$ \\
\hline Sample size $(n=24)$ & $\mathrm{RR}=1.000$ & $\begin{array}{l}1.000 \text { to } 1.000 \\
P=0.92\end{array}$ & $0 \%$ & $\begin{array}{l}\text { No evidence that risk ratio is associ- } \\
\text { ated with sample size }\end{array}$ \\
\hline
\end{tabular}

P-values adjusted for multiple testing

Table 5. Results of univariate meta-regression analysis for total MI

\begin{tabular}{|c|c|c|c|c|}
\hline Explanatory variable ( $\mathrm{n}$ trials) & $\begin{array}{l}\text { Exp(s- } \\
\text { lope })^{\star}\end{array}$ & $\begin{array}{l}\text { 95\% Confidence } \\
\text { interval } \\
\text { Univariate } P \text { value }\end{array}$ & $\begin{array}{l}\text { Propor- } \\
\text { tion of } \\
\text { variation } \\
\text { explained }\end{array}$ & Interpretation \\
\hline $\begin{array}{l}\text { Case mix } \\
(\% \text { MI patients) }(n=33)\end{array}$ & $\mathrm{RR}=1.005$ & $\begin{array}{l}0.994 \text { to } 1.016 \\
P=1.00\end{array}$ & $0 \%$ & $\begin{array}{l}\text { No evidence that risk ratio is associ- } \\
\text { ated with case mix }\end{array}$ \\
\hline $\begin{array}{l}\text { Dose of exercise (dose =number of weeks } \\
\text { of exercise training } x \text { average number of } \\
\text { sessions/week } x \text { average duration of ses- } \\
\text { sion in } \min )(n=25)\end{array}$ & $\mathrm{RR}=1.000$ & $\begin{array}{l}1.000 \text { to } 1.000 \\
P=1.00\end{array}$ & $0 \%$ & $\begin{array}{l}\text { No evidence that risk ratio is associ- } \\
\text { ated with increased dose of exercise }\end{array}$ \\
\hline $\begin{array}{l}\text { Type of CR } \\
\text { (exercise only vs comprehensive CR) ( } n= \\
\text { 33) }\end{array}$ & $\mathrm{RR}=0.784$ & $\begin{array}{l}0.575 \text { to } 1.070 \\
P=0.99\end{array}$ & $0 \%$ & $\begin{array}{l}\text { No evidence that risk ratio is associ- } \\
\text { ated with type of } C R\end{array}$ \\
\hline Duration of follow-up (months) $(n=33)$ & $\mathrm{RR}=0.997$ & $\begin{array}{l}0.992 \text { to } 1.003 \\
P=1.00\end{array}$ & $0 \%$ & $\begin{array}{l}\text { No evidence that risk ratio is associ- } \\
\text { ated with duration of follow-up }\end{array}$ \\
\hline
\end{tabular}


Table 5. Results of univariate meta-regression analysis for total MI (Continued)

\begin{tabular}{|c|c|c|c|c|}
\hline $\begin{array}{l}\text { Year of publication } \\
\text { (pre } 1995 \text { vs post 1995) }(n=33)\end{array}$ & $\mathrm{RR}=1.000$ & $\begin{array}{l}0.999 \text { to } 1.000 \\
P=0.94\end{array}$ & $0 \%$ & $\begin{array}{l}\text { No evidence that risk ratio is associ- } \\
\text { ated with year of publication }\end{array}$ \\
\hline Setting (centre vs home) $(n=33)$ & $\mathrm{RR}=0.792$ & $\begin{array}{l}0.655 \text { to } 0.957 \\
P=0.91\end{array}$ & $0 \%$ & $\begin{array}{l}\text { No evidence that risk ratio is associ- } \\
\text { ated with setting }\end{array}$ \\
\hline $\begin{array}{l}\text { Risk of bias (low risk in } \geq 5 \text { items } v<5 \\
\text { items) }(n=33)\end{array}$ & $\mathrm{RR}=0.963$ & $\begin{array}{l}0.889 \text { to } 1.042 \\
P=0.76\end{array}$ & $0 \%$ & $\begin{array}{l}\text { No evidence that risk ratio is associ- } \\
\text { ated with risk of bias }\end{array}$ \\
\hline Study location $(n=33)$ & $\mathrm{RR}=0.639$ & $\begin{array}{l}0.416 \text { to } 0.978 \\
P=1.00\end{array}$ & $0 \%$ & $\begin{array}{l}\text { No evidence that risk ratio is associ- } \\
\text { ated with study location }\end{array}$ \\
\hline Sample size $(n=33)$ & $\mathrm{RR}=1.000$ & $\begin{array}{l}1.000 \text { to } 1.000 \\
P=1.00\end{array}$ & $0 \%$ & $\begin{array}{l}\text { No evidence that risk ratio is associ- } \\
\text { ated with sample size }\end{array}$ \\
\hline
\end{tabular}

P-values adjusted for multiple testing

Table 6. Results of univariate meta-regression analysis for CABG

\begin{tabular}{|c|c|c|c|c|}
\hline Explanatory variable ( $\mathrm{n}$ trials) & $\begin{array}{l}\text { Exp(s- } \\
\text { lope })^{\star}\end{array}$ & $\begin{array}{l}\text { 95\% Confidence } \\
\text { interval } \\
\text { Univariate P value }\end{array}$ & $\begin{array}{l}\text { Propor- } \\
\text { tion of } \\
\text { variation } \\
\text { explained }\end{array}$ & Interpretation \\
\hline $\begin{array}{l}\text { Case mix } \\
(\% \text { MI patients) }(n=28)\end{array}$ & $\mathrm{RR}=1.009$ & $\begin{array}{l}1.000 \text { to } 1.018 \\
P=0.28\end{array}$ & $0 \%$ & $\begin{array}{l}\text { No evidence that risk ratio is associ- } \\
\text { ated with case mix }\end{array}$ \\
\hline $\begin{array}{l}\text { Dose of exercise (dose =number of weeks } \\
\text { of exercise training } x \text { average number of } \\
\text { sessions/week } x \text { average duration of ses- } \\
\text { sion in } \min )(n=23)\end{array}$ & $\mathrm{RR}=1.000$ & $\begin{array}{l}1.000 \text { to } 1.000 \\
P=0.93\end{array}$ & $0 \%$ & $\begin{array}{l}\text { No evidence that risk ratio is associ- } \\
\text { ated with increased dose of exercise }\end{array}$ \\
\hline $\begin{array}{l}\text { Type of CR } \\
\text { (exercise only vs CR rehab) }(n=28)\end{array}$ & $\mathrm{RR}=1.027$ & $\begin{array}{l}0.659 \text { to } 1.600 \\
P=0.27\end{array}$ & $0 \%$ & $\begin{array}{l}\text { No evidence that risk ratio is associ- } \\
\text { ated with type of } C R\end{array}$ \\
\hline Duration of follow-up (months) $(n=28)$ & $\mathrm{RR}=0.999$ & $\begin{array}{l}0.991 \text { to } 1.007 \\
P=0.98\end{array}$ & $0 \%$ & $\begin{array}{l}\text { No evidence of a change in risk ratio } \\
\text { with longer follow-up }\end{array}$ \\
\hline $\begin{array}{l}\text { Year of publication } \\
\text { (pre } 1995 \text { vs post } 1995)(n=28)\end{array}$ & $\mathrm{RR}=0.997$ & $\begin{array}{l}0.979 \text { to } 1.016 \\
P=1.00\end{array}$ & $0 \%$ & $\begin{array}{l}\text { No evidence that risk ratio is associ- } \\
\text { ated with year of publication }\end{array}$ \\
\hline Setting (centre vs home) $(n=28)$ & $\mathrm{RR}=1.090$ & $\begin{array}{l}0.876 \text { to } 1.357 \\
P=0.76\end{array}$ & $0 \%$ & $\begin{array}{l}\text { No evidence that risk ratio is associ- } \\
\text { ated with setting }\end{array}$ \\
\hline $\begin{array}{l}\text { Risk of bias (low risk in } \geq 5 \text { items } v<5 \\
\text { items) }(n=28)\end{array}$ & $\mathrm{RR}=0.981$ & $\begin{array}{l}0.882 \text { to } 1.091 \\
P=0.79\end{array}$ & $0 \%$ & $\begin{array}{l}\text { No evidence that risk ratio is associ- } \\
\text { ated with risk of bias }\end{array}$ \\
\hline
\end{tabular}


Table 6. Results of univariate meta-regression analysis for CABG (Continued)

\begin{tabular}{|c|c|c|c|c|}
\hline Study location $(n=28)$ & $\mathrm{RR}=1.199$ & $\begin{array}{l}0.819 \text { to } 1.754 \\
P=1.00\end{array}$ & $0 \%$ & $\begin{array}{l}\text { No evidence that risk ratio is associ- } \\
\text { ated with study location }\end{array}$ \\
\hline Sample size $(n=28)$ & $\mathrm{RR}=1.000$ & $\begin{array}{l}1.000 \text { to } 1.001 \\
P=1.00\end{array}$ & $0 \%$ & $\begin{array}{l}\text { No evidence that risk ratio is associ- } \\
\text { ated with sample size }\end{array}$ \\
\hline
\end{tabular}

P-values adjusted for multiple testing

Table 7. Results of univariate meta-regression analysis for $\mathrm{PCl}$

\begin{tabular}{|c|c|c|c|c|}
\hline Explanatory variable (n trials) & $\begin{array}{l}\text { Exp(s- } \\
\text { lope })^{\star}\end{array}$ & $\begin{array}{l}\text { 95\% Confidence } \\
\text { interval } \\
\text { Univariate } P \text { value }\end{array}$ & $\begin{array}{l}\text { Propor- } \\
\text { tion of } \\
\text { variation } \\
\text { explained }\end{array}$ & Interpretation \\
\hline $\begin{array}{l}\text { Case mix } \\
\text { (\% MI patients) }(n=15)\end{array}$ & $\mathrm{RR}=1.002$ & $\begin{array}{l}0.995 \text { to } 1.011 \\
P=1.00\end{array}$ & $0 \%$ & $\begin{array}{l}\text { No evidence that risk ratio is associ- } \\
\text { ated with case mix }\end{array}$ \\
\hline $\begin{array}{l}\text { Dose of exercise (number of weeks of ex- } \\
\text { ercise training } x \text { average number of ses- } \\
\text { sions/week } x \text { average duration of session } \\
\text { in } \min )(n=13)\end{array}$ & $\mathrm{RR}=1.000$ & $\begin{array}{l}1.000 \text { to } 1.000 \\
P=1.00\end{array}$ & $0 \%$ & $\begin{array}{l}\text { No evidence that risk ratio is associ- } \\
\text { ated with dose of exercise }\end{array}$ \\
\hline $\begin{array}{l}\text { Type of CR } \\
\text { (exercise only vs comprehensive CR) }(n= \\
\text { 14) }\end{array}$ & $\mathrm{RR}=1.071$ & $\begin{array}{l}0.456 \text { to } 2.519 \\
P=1.00\end{array}$ & $0 \%$ & $\begin{array}{l}\text { No evidence that risk ratio is associ- } \\
\text { ated with type of } C R\end{array}$ \\
\hline Duration of follow-up (months) $(n=13)$ & $\mathrm{RR}=0.998$ & $\begin{array}{l}0.988 \text { to } 1.007 \\
P=0.97\end{array}$ & $0 \%$ & $\begin{array}{l}\text { No evidence that risk ratio is associ- } \\
\text { ated with length of follow-up }\end{array}$ \\
\hline $\begin{array}{l}\text { Year of publication } \\
\text { (pre } 1995 \text { vs post } 1995)(n=15)\end{array}$ & $\mathrm{RR}=1.013$ & $\begin{array}{l}0.981 \text { to } 1.047 \\
P=1.00\end{array}$ & $0 \%$ & $\begin{array}{l}\text { No evidence that risk ratio is associ- } \\
\text { ated with year of publication }\end{array}$ \\
\hline Setting (centre vs home) $(n=15)$ & $\mathrm{RR}=0.903$ & $\begin{array}{l}0.707 \text { to } 1.153 \\
P=0.98\end{array}$ & $0 \%$ & $\begin{array}{l}\text { No evidence that risk ratio is associ- } \\
\text { ated with setting }\end{array}$ \\
\hline $\begin{array}{l}\text { Risk of bias (low risk in } \geq 5 \text { items } v<5 \\
\text { items) }(n=15)\end{array}$ & $\mathrm{RR}=1.022$ & $\begin{array}{l}0.915 \text { to } 1.141 \\
P=0.96\end{array}$ & $0 \%$ & $\begin{array}{l}\text { No evidence that risk ratio is associ- } \\
\text { ated with risk of bias }\end{array}$ \\
\hline Study location $(n=14)$ & $\mathrm{RR}=0.866$ & $\begin{array}{l}0.547 \text { to } 1.369 \\
P=1.00\end{array}$ & $0 \%$ & $\begin{array}{l}\text { No evidence that risk ratio is associ- } \\
\text { ated with study location }\end{array}$ \\
\hline Sample size $(n=15)$ & $\mathrm{RR}=0.998$ & $\begin{array}{l}0.989 \text { to } 1.007 \\
P=1.00\end{array}$ & $0 \%$ & $\begin{array}{l}\text { No evidence that risk ratio is associ- } \\
\text { ated with sample size }\end{array}$ \\
\hline
\end{tabular}

P-values adjusted for multiple testing 
Table 8. Results of univariate meta-regression analysis for hospitalisations

\begin{tabular}{|c|c|c|c|c|}
\hline Explanatory variable (n trials) & $\begin{array}{l}\text { Exp(s- } \\
\text { lope)* }\end{array}$ & $\begin{array}{l}\text { 95\% Confidence } \\
\text { interval } \\
\text { Univariate } P \text { value }\end{array}$ & $\begin{array}{l}\text { Propor- } \\
\text { tion of } \\
\text { variation } \\
\text { explained }\end{array}$ & Interpretation \\
\hline $\begin{array}{l}\text { Case mix } \\
(\% \text { MI patients) }(n=14)\end{array}$ & $\mathrm{RR}=1.004$ & $\begin{array}{l}0.996 \text { to } 1.011 \\
P=0.53\end{array}$ & $0 \%$ & $\begin{array}{l}\text { No evidence that risk ratio is associ- } \\
\text { ated with case mix }\end{array}$ \\
\hline $\begin{array}{l}\text { Dose of exercise (number of weeks of ex- } \\
\text { ercise training } x \text { average number of ses- } \\
\text { sions/week } x \text { average duration of session } \\
\text { in } \min \text { ) }(n=11)\end{array}$ & $\mathrm{RR}=1.000$ & $\begin{array}{l}1.000 \text { to } 1.000 \\
P=1.00\end{array}$ & $0 \%$ & $\begin{array}{l}\text { No evidence that risk ratio is associ- } \\
\text { ated with dose of exercise }\end{array}$ \\
\hline $\begin{array}{l}\text { Type of CR } \\
\text { (exercise only vs comprehensive CR) ( } n= \\
\text { 13) }\end{array}$ & $\mathrm{RR}=0.902$ & $\begin{array}{l}0.537 \text { to } 1.515 \\
P=1.00\end{array}$ & $0 \%$ & $\begin{array}{l}\text { No evidence that risk ratio is associ- } \\
\text { ated with type of } C R\end{array}$ \\
\hline Duration of follow-up (months) $(n=13)$ & $\mathrm{RR}=1.005$ & $\begin{array}{l}0.995 \text { to } 1.016 \\
P=0.65\end{array}$ & $0 \%$ & $\begin{array}{l}\text { No evidence that risk ratio is associ- } \\
\text { ated with length of follow-up }\end{array}$ \\
\hline $\begin{array}{l}\text { Year of publication } \\
\text { (pre } 1995 \text { vs post } 1995)(n=14)\end{array}$ & $\mathrm{RR}=0.993$ & $\begin{array}{l}0.971 \text { to } 1.015 \\
P=0.99\end{array}$ & $0 \%$ & $\begin{array}{l}\text { No evidence that risk ratio is associ- } \\
\text { ated with year of publication }\end{array}$ \\
\hline Setting (centre vs home) $(n=14)$ & $\begin{array}{l}\mathrm{RR}=0 . \\
954\end{array}$ & $\begin{array}{l}0.819 \text { to } 1.112 \\
P=1.00\end{array}$ & $0 \%$ & $\begin{array}{l}\text { No evidence that risk ratio is associ- } \\
\text { ated with setting }\end{array}$ \\
\hline $\begin{array}{l}\text { Risk of bias (low risk in } \geq 5 \text { items } v<5 \\
\text { items) }(n=14)\end{array}$ & $\mathrm{RR}=1.022$ & $\begin{array}{l}0.920 \text { to } 1.135 \\
P=1.00\end{array}$ & $0 \%$ & $\begin{array}{l}\text { No evidence that risk ratio is associ- } \\
\text { ated with risk of bias }\end{array}$ \\
\hline Study location $(n=14)$ & $\begin{array}{l}\mathrm{RR}= \\
0.908\end{array}$ & $\begin{array}{l}0.687 \text { to } 1.200 \\
P=1.00\end{array}$ & $0 \%$ & $\begin{array}{l}\text { No evidence that risk ratio is associ- } \\
\text { ated with study location }\end{array}$ \\
\hline Sample size $(n=14)$ & $\mathrm{RR}=1.000$ & $\begin{array}{l}1.000 \text { to } 1.001 \\
P=0.43\end{array}$ & $0 \%$ & $\begin{array}{l}\text { No evidence that risk ratio is associ- } \\
\text { ated with sample size }\end{array}$ \\
\hline
\end{tabular}

P-values adjusted for multiple testing

\section{APPENDICES}

\section{Appendix 1. Search strategies}

\section{CENTRAL, DARE \& HTA}

\#1 MeSH descriptor: [Myocardial Ischemia] explode all trees

\#2 (myocard ${ }^{\star}$ near isch $\left.{ }^{\star} \mathrm{mi}^{\star}\right)$ :ti,ab,kw (Word variations have been searched)

\#3 isch*mi* near heart:ti,ab,kw (Word variations have been searched)

\#4 MeSH descriptor: [Coronary Artery Bypass] explode all trees

\#5 myocard* near infarct*:ti,ab,kw (Word variations have been searched) 
\#6 heart near infarct*:ti,ab,kw (Word variations have been searched)

\#7 angina:ti,ab,kw (Word variations have been searched)

\#8 coronary near (disease* or bypass or thrombo* or angioplast ${ }^{\star}$ ):ti,ab,kw (Word variations have been searched)

\#9 MeSH descriptor: [Percutaneous Coronary Intervention] explode all trees

\#10 (percutaneous next coronary near/2 (interven* or revascular $\left.{ }^{\star}\right)$ )

\#11 MeSH descriptor: [Angioplasty] explode all trees

$\# 12$ angioplast*

\#13 ((coronary or arterial) near/4 dilat $\left.{ }^{\star}\right)$

\#14 endoluminal next repair*

\#15 MeSH descriptor: [Stents] explode all trees

\#16 stent*

\#17 pci or ptca

\#18 MeSH descriptor: [Atherectomy] explode all trees

\#19 atherectom*

\#20 acute next coronary next syndrom*

\#21 (\#1 or \#2 or \#3 or \#4 or \#5 or \#6 or \#7 or \#8)

$\# 22 \# 1$ or \#2 or \#3 or \#4 or \#5 or \#6 or \#7 or \#8 or \#9 or \#10 or \#11 or \#12 or \#13 or \#14 or \#15 or \#16 or \#17 or \#18 or \#19 or \#20

\#23 MeSH descriptor: [Exercise Therapy] explode all trees

\#24 MeSH descriptor: [Sports] explode all trees

\#25 MeSH descriptor: [Physical Exertion] explode all trees

\#26 rehabilitat*:ti,ab,kw (Word variations have been searched)

\#27 (physical* near (fit* or train* or therap* or activit*)):ti,ab,kw (Word variations have been searched)

\#28 MeSH descriptor: [Exercise] explode all trees

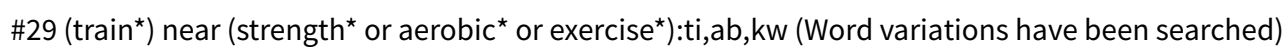

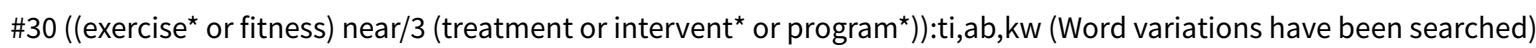

\#31 MeSH descriptor: [Rehabilitation] explode all trees

\#32 kinesiotherap*:ti,ab,kw (Word variations have been searched)

\#33 MeSH descriptor: [Physical Education and Training] explode all trees

\#34 MeSH descriptor: [Patient Education as Topic] this term only

\#35 (patient* near/5 educat*)

\#36 ((lifestyle or life-style) near/5 (interven* or program ${ }^{\star}$ or treatment $\left.^{\star}\right)$ )

\#37 MeSH descriptor: [Self Care] this term only

\#38 (self near/5 (manag* or care or motivate $\left.{ }^{\star}\right)$ )

\#39 MeSH descriptor: [Psychotherapy] explode all trees

\#40 psychotherap* 
\#41 (psycholog* near/5 intervent ${ }^{\star}$ )

\#42 MeSH descriptor: [Counseling] this term only

\#43 (counselling or counseling)

\#44 ((behavior* or behaviour $\left.{ }^{\star}\right)$ near/5 (modify or modificat* or therap* or change))

\#45 (psycho-educat* or psychoeducat ${ }^{\star}$ )

\#46 (motivat ${ }^{\star}$ near/5 (intervention or interv $\left.{ }^{\star}\right)$ )

\#47 MeSH descriptor: [Health Education] this term only

\#48 (health near/5 educat*)

\#49 (psychosocial or psycho-social)

\#50 (cognitive near/2 behav ${ }^{\star}$ )

$\# 51 \# 23$ or \#24 or \#25 or \#26 or \#27 or \#28 or \#29 or \#30 or \#31 or \#32 or \#33

$\# 52 \# 23$ or \#24 or \#25 or \#26 or \#27 or \#28 or \#29 or \#30 or \#31 or \#32 or \#33 or \#34 or \#35 or \#36 or \#37 or \#38 or \#39 or \#40 or \#41 or \#42 or \#43 or \#44 or \#45 or \#46 or \#47 or \#48 or \#49 or \#50

$\# 53 \# 21$ and \#51

\#54 \#22 and \#52

\#55 \#54 not \#53

\#56 \#53 Publication Year from 2009 to 2014

\#57 \#55 or \#56

\#58 \#51 and \#21

\section{MEDLINE OVID}

1. exp Myocardial Ischemia/

2. (myocard* adj5 (ischaemia or ischemia)).tw.

3. (isch?emi* adj5 heart).tw.

4. exp Coronary Artery Bypass/

5. (myocard $^{\star}$ adj5 infarct $\left.{ }^{\star}\right)$.tw.

6. (heart adj5 infarct $\left.{ }^{\star}\right)$.tw.

7. angina.tw.

8. (coronary adj5 (disease ${ }^{\star}$ or bypass or thrombo* or angioplast $\left.{ }^{\star}\right)$ ).tw.

9. exp Percutaneous Coronary Intervention/

10. (percutaneous coronary adj2 (interven* or revascular*)).tw.

11. exp Angioplasty/

12. angioplast ${ }^{\star}$. tw.

13. ((coronary or arterial) adj4 dilat*).tw.

14. endoluminal repair ${ }^{\star}$.tw.

15. exp Stents/ 
16. stent ${ }^{\star}$. tw.

17. (pci or ptca).tw.

18. exp Atherectomy/

19. atherectom*.tw.

20. acute coronary syndrom ${ }^{\star}$. tw.

21. or $/ 1-8$

22. or $/ 1-20$

23. exp Exercise Therapy/

24. Sports/

25. Physical Exertion/

26. rehabilitat*.mp.

27. (physical ${ }^{\star}$ adj5 (fit ${ }^{\star}$ or train ${ }^{\star}$ or therap ${ }^{\star}$ or activit $\left.\left.{ }^{\star}\right)\right) \cdot m p$.

28. exp Exercise/

29. (train ${ }^{\star}$ adj5 (strength ${ }^{\star}$ or aerobic ${ }^{\star}$ or exercise $\left.\left.{ }^{\star}\right)\right)$. tw.

30. ((exercise ${ }^{\star}$ or fitness) adj3 (treatment or intervent ${ }^{\star}$ or program $\left.\left.{ }^{\star}\right)\right)$.tw.

31. exp Rehabilitation/

32. kinesiotherap ${ }^{\star} . t w$.

33. "Physical Education and Training"/

34. Patient Education as Topic/

35. (patient $^{\star}$ adj5 educat $\left.{ }^{\star}\right)$.tw.

36. ((lifestyle or life-style) adj5 (interven* or program ${ }^{\star}$ or treatment $\left.\left.{ }^{\star}\right)\right)$. .tw.

37. Self Care/

38. (self adj5 (manag* or care or motivate*)).tw.

39. exp Psychotherapy/

40. psychotherap ${ }^{\star}$.tw.

41. (psycholog* adj5 intervent*).tw.

42. Counseling/

43. (counselling or counseling).tw.

44. ((behavior* ${ }^{\star}$ r behaviour $\left.{ }^{\star}\right)$ adj5 (modify or modificat ${ }^{\star}$ or therap ${ }^{\star}$ or change)).tw.

45. (psycho-educat* ${ }^{\star}$ or psychoeducat $\left.{ }^{\star}\right)$.tw.

46. (motivat* $\operatorname{adj5}\left(\right.$ intervention or interv $\left.\left.{ }^{\star}\right)\right)$.tw.

47. Health Education/

48. (health adj5 educat $\left.{ }^{\star}\right)$.tw.

49. (psychosocial or psycho-social).tw.

50. (cognitive adj2 behav $\left.{ }^{\star}\right)$.tw. 
51. or/23-33

52. $\mathrm{or} / 23-50$

53. 21 and 51

54. 22 and 52

55. randomized controlled trial.pt.

56. controlled clinical trial.pt.

57. randomized.ab.

58. placebo.ab.

59. drug therapy.fs.

60. randomly.ab.

61. trial.ab.

62. groups.ab.

63.55 or 56 or 57 or 58 or 59 or 60 or 61 or 62

64. exp animals/ not humans.sh.

65.63 not 64

66. 53 and 65

67.54 and 65

68.67 not 66

69. $\left(200912^{\star}\right.$ or $2010^{\star}$ or $2011^{\star}$ or $2012^{\star}$ or $2013^{\star}$ or $\left.2014^{\star}\right)$.ed.

70.66 and 69

71.68 or 70

\section{EMBASE OVID}

1. exp Heart Muscle Ischemia/

2. (myocard* ${ }^{\star} \operatorname{adj} 5$ (ischaemia or ischemia)).tw.

3. (isch?emi ${ }^{\star}$ adj5 heart).tw.

4. exp Coronary Artery Bypass Graft/

5. (myocard $^{\star}$ adj5 infarct $\left.{ }^{\star}\right)$.tw.

6. (heart adj5 infarct $\left.{ }^{\star}\right)$.tw.

7. angina.tw.

8. (coronary adj5 (disease ${ }^{\star}$ or bypass or thrombo* or angioplast*)).tw.

9. exp percutaneous coronary intervention/

10. (percutaneous coronary adj2 (interven* or revascular $\left.{ }^{\star}\right)$ ).tw.

11. exp angioplasty/

12. angioplast*.tw.

13. ((coronary or arterial) adj4 dilat*).tw. 
14. endoluminal repair*.tw.

15. exp stent/

16. stent ${ }^{\star}$. tw.

17. (pci or ptca).tw.

18. exp atherectomy/

19. atherectom ${ }^{\star}$. tw.

20. acute coronary syndrom ${ }^{\star}$. tw.

21. or $/ 1-8$

22. or/1-20

23. exp Kinesiotherapy/

24. Sport/

25. rehabilitat ${ }^{\star} . \mathrm{mp}$.

26. (physical ${ }^{\star}$ adj5 (fit ${ }^{\star}$ or train ${ }^{\star}$ or therap* or activit $\left.^{\star}\right)$ ).mp.

27. exp Exercise/

28. (train ${ }^{\star} \operatorname{adj} 5$ (strength ${ }^{\star}$ or aerobic ${ }^{\star}$ or exercise $\left.\left.{ }^{\star}\right)\right)$. tw.

29. ((exercise* or fitness) adj3 (treatment or intervent ${ }^{\star}$ or program $\left.{ }^{\star}\right)$ ).tw.

30. exp Rehabilitation/

31. kinesiotherap*.tw.

32. Physical Education/

33. patient education/

34. (patient $^{\star}$ adj5 educat $\left.{ }^{\star}\right)$.tw.

35. ((lifestyle or life-style) adj5 (interven ${ }^{\star}$ or program or treatment $\left.\left.{ }^{\star}\right)\right)$.tw.

36. self care/

37. (self adj5 (manag* or care or motivate*)).tw.

38. exp psychotherapy/

39. psychotherap ${ }^{\star}$.tw.

40. (psycholog* adj5 intervent $\left.{ }^{\star}\right)$.tw.

41. counseling/

42. (counselling or counseling).tw.

43. ((behavior ${ }^{\star}$ or behaviour ${ }^{\star}$ ) adj5 (modify or modificat ${ }^{\star}$ or therap ${ }^{\star}$ or change)).tw.

44. (psycho-educat* or psychoeducat $\left.{ }^{\star}\right)$.tw.

45. (motivat* adj5 (intervention or interv $\left.{ }^{\star}\right)$ ).tw.

46. health education/

47. (health adj5 educat $\left.{ }^{\star}\right)$.tw.

48. (psychosocial or psycho-social).tw. 
49. (cognitive adj2 behav ${ }^{\star}$ ).tw.

50. or/23-32

51. or/23-49

52. 21 and 50

53. 22 and 51

54. random\$.tw.

55. factorial\$̣.tw.

56. crossover\$.tw.

57. cross over\$.tw.

58. cross-over\$.tw.

59. placebo\$.tw.

60. (doubl\$ adj blind\$).tw.

61. (singl\$ adj blind\$).tw.

62. assign\$s.tw.

63. allocat\$.tw.

64. volunteer\$.tw.

65. crossover procedure/

66. double blind procedure/

67. randomized controlled trial/

68. single blind procedure/

69.54 or 55 or 56 or 57 or 58 or 59 or 60 or 61 or 62 or 63 or 64 or 65 or 66 or 67 or 68

70. (animal/ or nonhuman/) not human/

71.69 not 70

72.52 and 71

73. $\left(200912^{\star}\right.$ or $2010^{\star}$ or $2011^{\star}$ or $2012^{\star}$ or $2013^{\star}$ or $\left.2014^{\star}\right)$.dd.

74. 72 and 73

75.53 and 71

76. 75 not 72

77.74 or 76

78. limit 77 to embase

\section{Web of Science (SCI \& CPCI-S)}

\# 16 \#15 OR \#14

\# 15 \#12 Indexes=SCI-EXPANDED, CPCI-S Timespan=2009-2014

\# 14 \#13 not \#12

\# 13 \#11 AND \#10 
\# 12 \#11 AND \#7

\# 11 TS=(random ${ }^{\star}$ or blind ${ }^{\star}$ or allocat ${ }^{\star}$ or assign ${ }^{\star}$ or trial* ${ }^{\star}$ or placebo* or crossover $^{\star}$ or cross-over $\left.^{\star}\right)$

\# 10 \#9 AND \#6

\# 9 \#8 OR \#4 OR \#3 OR \#2 OR \#1

\# $8 \mathrm{TS}=\left(\mathrm{PCl}\right.$ or percutaneous or angioplast ${ }^{\star}$ or "endoluminal repair ${ }^{\star}$ " or stent ${ }^{\star}$ or atherectom* or "acute coronary syndrom*")

\# 7 \#6 AND \#5

\# $6 \mathrm{TS}=\left(\left(\right.\right.$ rehab $^{\star}$ or educat $\left.\left.{ }^{\star}\right)\right)$

\# 5 \#4 OR \#3 OR \#2 OR \#1

\# 4 TS=((angina or cardiac* or PTCA or CABG))

\# 3 TS=(((heart) SAME (infarct* or isch?emia or failure or attack $)))$

\# 2 TS=(((coronary ${ }^{\star}$ or heart* $)$ SAME (by?pass or disease $\left.\left.\left.{ }^{\star}\right)\right)\right)$

\# 1 TS=(((myocard $\left.{ }^{\star}\right)$ SAME (isch?emia or infarct* or revasculari?*$\left.\left.)\right)\right)$

\section{CINAHL Plus (EBSCO)}

\section{S76 S43 OR S75}

S75 S74 not S41

S74 S40 AND S55 AND S73

S73 S22 OR S56 OR S57 OR S58 OR S59 OR S60 OR S61 OR S62 OR S63 OR S64 OR S65 OR S66 OR S67 OR S68 OR S69 OR S70 OR S71 OR S72

S72 (cognitive N2 behav ${ }^{\star}$ )

S71 (psychosocial or psycho-social)

S70 (health N5 educat ${ }^{\star}$ )

S69 (MH "Health Education")

S68 (motivat* N5 (intervention or interv $\left.\left.{ }^{\star}\right)\right)$

S67 (psycho-educat* or psychoeducat ${ }^{\star}$ )

S66 ((behavior* or behaviour ${ }^{\star}$ ) N5 (modify or modificat* or therap* or change))

S65 (counselling or counseling)

S64 (MH "Counseling")

S63 (psycholog* N5 intervent ${ }^{\star}$ )

S62 psychotherap*

S61 (MH "Psychotherapy+")

S60 (self N5 (manag* or care or motivate*))

S59 (MH "Self Care")

S58 ((lifestyle or life-style) N5 (interven* or program* or treatment $\left.\left.{ }^{\star}\right)\right)$

S57 (patient ${ }^{\star}$ N5 educat ${ }^{\star}$ )

S56 (MH "Patient Education")

S55 S10 OR S44 OR S45 OR S46 OR S47 OR S48 OR S49 OR S50 OR S51 OR S52 OR S53 OR S54 
S54 "acute coronary syndrom*"

S53 atherectom*

S52 (MH "Atherectomy+")

S51 pci or ptca

S50 stent ${ }^{*}$

S49 (MH "Stents+")

S48 "endoluminal repair*"

S47 ((coronary or arterial) N4 dilat $\left.{ }^{\star}\right)$

S46 angioplast*

S45 (MH "Angioplasty+")

S44 (percutaneous coronary N2 (interven* or revascular*))

S43 S41 AND S42

S42 Limiters - Published Date: 20091201-20140731

S41 S10 AND S22 AND S40

$\mathrm{S} 40 \mathrm{~S} 23$ or S24 or S25 or S26 or S27 or S28 or S29 or S30 or S31 or S32 or S33 or S34 or S35 or S36 or S37 or S38 or S39

S39 TX cross-over*

S38 TX crossover*

S37 TX volunteer*

S36 (MH "Crossover Design")

S35 TX allocat*

S34 TX control*

S33 TX assign*

S32 TX placebo*

S31 (MH "Placebos")

S30 TX random*

S29 TX (doubl* N1 mask*)

S28 TX (singl* N1 mask ${ }^{\star}$ )

S27 TX (doubl* N1 blind ${ }^{\star}$ )

S26 TX (singl* N1 blind ${ }^{\star}$ )

S25 TX (clinic* N1 trial?)

S24 PT clinical trial

S23 (MH "Clinical Trials+")

S22 S11 OR S12 OR S13 OR S14 OR S15 OR S16 OR S17 OR S18 OR S19 OR S20 OR S21

S21 (MH "Physical Education and Training")

S20 kinesiotherap * 
S19 (MH "Rehabilitation+")

S18 ((exercise ${ }^{\star}$ or fitness) N3 (treatment or intervent ${ }^{\star}$ or program $\left.{ }^{\star}\right)$ )

S17 (train ${ }^{\star}$ N5 (strength ${ }^{\star}$ or aerobic ${ }^{\star}$ or exercise $\left.{ }^{\star}\right)$ )

S16 (MH "Exercise+")

S15 (physical ${ }^{\star}$ N5 (fit ${ }^{\star}$ or train* or therap* or activit*))

S14 rehabilitat*

S13 (MH "Physical Activity")

S12 (MH "Sports")

S11 (MH "Therapeutic Exercise+")

S10 S1 OR S2 OR S3 OR S4 OR S5 OR S6 OR S7 OR S8 OR S9

S9 (coronary N5 (disease* or bypass or thrombo* or angioplast*))

S8 angina

S7 (heart N5 infarct*)

S6 (heart N5 infarct ${ }^{\star}$ )

S5 (myocard* N5 infarct $\left.{ }^{\star}\right)$

S4 (MH "Coronary Artery Bypass+")

S3 (isch?emi* N5 heart)

S2 (myocard* N5 (ischaemia or ischemia))

S1 (MH "Myocardial Ischemia+")

WHO'S ICTRP

"Cardiac rehabilitation"

rehabilitation AND "coronary heart disease"

exercise AND "coronary heart disease"

\section{Clinicaltrials.gov}

"Cardiac rehabilitation"

rehabilitation AND "coronary heart disease"

exercise AND "coronary heart disease"

\section{Appendix 2. Glossary}

Angina pectoris: commonly known as angina, is the sensation of chest pain, pressure, or squeezing, often due to ischemia of the heart muscle from obstruction or spasm of the coronary arteries

Angioplasty: A treatment to expand a narrowed artery.

Arrhythmia: An abnormal heart rhythm.

Atheroma: The fatty material that can build up within the walls of your arteries.

Atherosclerosis: The build-up of fatty materials within the walls of your arteries, causing them to narrow.

Cardiovascular: To do with the heart and blood vessels. 
Coronary artery bypass surgery: also known as coronary artery bypass graft (CABG) surgery, and colloquially heart bypass or bypass surgery, is a surgical procedure to improve the blood supply to the heart

Coronary heart disease (CHD): also known as coronary artery disease (CAD), ischemic heart disease (IHD), or atherosclerotic heart disease, is a group of diseases that includes: stable angina, unstable angina, myocardial infarction, and sudden coronary death. It is caused when the walls of your coronary arteries become narrowed by a gradual build-up of atheroma, allowing too little blood flow to the heart from the coronary arteries.

Echocardiogram: often referred to as a cardiac echo or simply an echo, is a sonogram of the heart. Echocardiography uses standard twodimensional, three-dimensional, and Doppler ultrasound to create images of the heart.

Electrocardiogram (ECG): is a test that checks for problems with the electrical activity of your heart. An ECG shows the heart's electrical activity as line tracings on paper. The spikes and dips in the tracings are called waves. The heart is a muscular pump made up of four chambers.

Heart attack: (Myocardial infarction [MI] or acute myocardial infarction [AMI]), occurs when blood flow stops to a part of the heart, starving it of oxygen and causing damage to the heart muscle.

Heart failure (HF): often referred to as congestive heart failure (CHF), occurs when the heart is unable to pump sufficiently to maintain blood flow to meet the needs of yourbody.

Heart rate: The number of times your heart beats in a minute.

Implantable Cardiovertor Defibrillator (ICD): A device implanted within your chest wall to monitor your heart's rhythm. If there is a dangerous abnormal rhythm the ICD can treat it by giving your heart an electric shock.

Intermittent claudication: A cramp like pain mostly in your calf and leg muscles which is caused by a lack of oxygen in the blood. It is often brought on by walking and relieved by rest.

Ischaemia: a restriction in blood supply to tissues, causing a shortage of oxygen and glucose needed.

Ischaemic heart disease (IHD): see Coronary heart disease (CHD)

Myocardial infarction (MI) or acute myocardial infarction (AMI): commonly known as a heart attack, occurs when blood flow stops to a part of the heart causing damage to the heart muscle.

Percutaneous coronary intervention (PCI): commonly known as coronary angioplasty, is a non-surgical procedure used to treat the stenotic (narrowed) coronary arteries of the heart found in coronary heart disease.

Re-vascularisation: A procedure that either opens up the existing blood vessels or bypasses the blockage of the coronary arteries.

Risk factor for coronary heart disease: Something that can increase your risk of getting coronary heart disease. Risk factors include smoking, high blood pressure, raised cholesterol, physical inactivity, obesity, diabetes, your sex, your ethnic background, your age and whether you have a family history of heart disease.

ST segment: is the flat, isoelectric section of the ECG trace, between the end of the S wave (the J point) and the beginning of the T wave

WHAT'S NEW

\begin{tabular}{lll}
\hline Date & Event & Description \\
\hline 8 January 2018 & Amended & minor error corrected in Summary of Findings table 1 \\
\hline
\end{tabular}

\section{H I S T O R Y}

Protocol first published: Issue 3, 1999

Review first published: Issue 4, 2000 


\begin{tabular}{|c|c|c|}
\hline Date & Event & Description \\
\hline 3 September 2015 & $\begin{array}{l}\text { New citation required but conclusions } \\
\text { have not changed }\end{array}$ & No substantive change in review conclusions \\
\hline 3 September 2015 & New search has been performed & No substantive change in review conclusions \\
\hline 24 February 2015 & Amended & New Author (Nicole Martin) added \\
\hline 24 February 2015 & Amended & New Author (Lindsey Anderson) added \\
\hline 24 February 2015 & Amended & Author (David Thompson) details updated \\
\hline 24 February 2015 & Amended & New Author (Ann-Dorthe Zwisler) added \\
\hline \multirow[t]{2}{*}{7 June 2011} & $\begin{array}{l}\text { New citation required and conclusions } \\
\text { have changed }\end{array}$ & $\begin{array}{l}\text { The inclusion criteria have been revised for this update. Five out } \\
\text { of the } 35 \text { formerly included studies (in the review) have therefore } \\
\text { been excluded. }\end{array}$ \\
\hline & & $\begin{array}{l}\text { The conclusions have changed based on the analysis of } 47 \text { in- } \\
\text { cluded studies and have focused more on the impact of exer- } \\
\text { cise-based cardiac rehabilitation on clinical events and HRQL } \\
\text { outcomes. }\end{array}$ \\
\hline 7 June 2011 & New search has been performed & $\begin{array}{l}\text { The searches were updated and re-run in December } 2009 \text {, identi- } \\
\text { fying an additional } 17 \text { studies for inclusion. Fourty-seven trials in } \\
\text { total have been included. }\end{array}$ \\
\hline 1 November 2000 & $\begin{array}{l}\text { New citation required and conclusions } \\
\text { have changed }\end{array}$ & Substantive amendment \\
\hline
\end{tabular}

\section{CONTRIBUTIONS OF AUTHORS}

This update review was undertaken by LA and RST, i.e. study selection, data extraction and risk of bias assessment. NM updated and ran the searches. ADZ provided clinical advice during the process of the update. LA, RST and DRT wrote the first draft of the update review, and all co-authors contributed to review and editing of drafts of the report. All authors approved the final manuscript.

\section{DECLARATIONS OF INTEREST}

RST, KR, NO and DRT were authors of the original Cochrane review. RST is an author on number of other Cochrane CR reviews and is currently the co-chief investigator on the programme of research with the overarching aims of developing and evaluating a home-based CR intervention for people with heart failure and their carers (PGFAR RP-PG-0611-12004). ADZ is an author on other Cochrane CR reviews and the Principal Investigator of ongoing CR trials (the DANREHAB trial and the CopenHeart trials). NM and LA have no known conflicts of interest.

\section{SOURCES OF SUPPORT}

\section{Internal sources}

- University of Exeter Medical School, UK.

\section{External sources}

- No sources of support provided, UK.

\section{DIFFERENCES BETWEEN PROTOCOLANDREVIEW}

In order to reflect current practice and terminology, "percutaneous transluminal coronary angioplasty" (PTCA) has been replaced by "percutaneous coronary intervention" ( $\mathrm{PCl})$, a term which encompasses the use of balloons, stents, and atherectomy. Also, given that a number of trials in this update report longer term duration of follow-up we extended the stratification of the meta-analysis according to 
time of follow-up, i.e. short-term (6 to 12 months); medium-term (13 to 36 months) and long-term ( $>36$ months). In addition, the following four additional covariates were added during the review process to test the $a$ priori hypotheses that there may be differences in the effect of exercise-based CR on total mortality, cardiovascular mortality, total MI, and revascularisation (CABG and PCI) across particular subgroups: (1) sample size; (2) setting (home- or centre-based CR); (3) risk of bias (absence of bias in < 5 out of 8 domains); and (4) study location (continent). Finally, although we found no substantial statistical heterogeneity associated with an effect estimate for any clinical event outcome ( $P$ value $<0.10, I^{2}>30 \%$ ), with the exception of hospital admissions, given the clinical heterogeneity of the included trials, we applied a more conservative random effects model to all analyses.

\section{N DEX TERMS}

\section{Medical Subject Headings (MeSH)}

^Exercise Therapy; Coronary Disease [mortality] [ ${ }^{\star}$ rehabilitation]; Health Status; Hospitalization; Myocardial Infarction [mortality] [rehabilitation]; Myocardial Revascularization [rehabilitation] [statistics \& numerical data]; Outcome Assessment, Health Care; Quality of Life; Randomized Controlled Trials as Topic

\section{MeSH check words}

Female; Humans; Male 